\title{
TECHNIQUES FOR TRIGGERING GERMINATION OF ADENOSTOMA FASCICULATUM IN REVEGETATION PROJECTS AT ROCKY CANYON GRANITE QUARRY
}

\author{
A Thesis \\ Presented to \\ the Faculty of California Polytechnic State University, \\ San Luis Obispo
}

\author{
In Partial Fulfillment \\ of the Requirements for the Degree \\ Master of Science in Biological Sciences
}

by

Stephanie Brook Scolari

December 2009 
(C) 2009

Stephanie Brook Scolari

ALL RIGHTS RESERVED 


\section{COMMITTEE MEMBERSHIP}

TITLE:

AUTHOR:

DATE SUBMITTED:

COMMITTEE CHAIR:

COMMITTEE MEMBER:

COMMITTEE MEMBER:
Techniques for Triggering Germination of Adenostoma fasciculatum in Revegetation Projects at Rocky Canyon Granite Quarry

Stephanie Brook Scolari

December 2009
Dr. V.L. Holland, Professor Emeritus

Dr. Andrew Schaffner, Associate Professor

Dr. Matthew Ritter, Associate Professor 


\author{
ABSTRACT \\ Techniques for Triggering Germination of Adenostoma \\ fasciculatum in Revegetation Projects at Rocky \\ Canyon Granite Quarry \\ Stephanie Brook Scolari
}

Rocky Canyon Quarry is a granite mine located in the Santa Lucia Mountains about 5 miles southeast of the city of Atascadero. The Surface Mining and Reclamation Act (SMARA), which passed in 1975, dictates that California mines must rehabilitate lands disturbed by mining operations. Dr. V. L. Holland and his students in the Biological Sciences Department at California Polytechnic State University, San Luis Obispo (Cal Poly) have been working on restoration and revegetation of the Rocky Canyon Quarry since the early 1990's.

Adenostoma fasciculatum (chamise) dominates the chaparral communities (chamisal chaparral) found in Rocky Canyon. Chamise is the most common shrub in much of California's chaparral and is adapted to recovery after fires by both seed germination and lignotuber sprouting. In laboratory and greenhouse experiments, it has been shown that chamise seeds have an increased germination rate when subjected to fire related stimulates such as heat, smoke, and charate. The goal of my research, which was conducted over a two year period (2002-2004), is to find successful, inexpensive techniques to restore chamisal chaparral on the mined granite slopes of Rocky Canyon Quarry. My study focused on examining and comparing the different techniques that have been shown by other researchers in laboratory and greenhouse situations to increase the germination rate of chamise. I compared the effects of heat, sulfuric acid, powdered charred wood (charate), and smoke on the germination of chamise seeds under the natural field conditions found in the Rocky Canyon Granite Quarry. Seeds were subjected to between one and four of these treatments, to examine possible interactive effects amongst the treatments, and then placed in plots containing the topsoil used to restore the mined hillsides. Plots remained under natural field conditions, and seedlings were counted following emergence. Results of my studies indicate that the smoke related treatments of liquid smoke and chamise smoke have the greatest effect in increasing the seed germination rate of chamise and that there is little to no benefit in subjecting chamise seeds to more than one treatment. 


\section{ACKNOWLEDGMENTS}

It is a great pleasure to thank all those who aided me during the course of this investigation. I wish to thank Dr. V.L. Holland for his many valuable suggestions throughout the course of this investigation and during the preparation of the manuscript. I also wish to express my gratitude to Dr. Andrew Schaffner for his invaluable help with the statistical analysis and Dr. Matt Ritter for his very helpful suggestions. I also wish to thank Union Asphalt, Inc for providing funding for the project and all the employees of the Rocky Canyon Quarry for their kind support and assistance on the project site. A special thank you must be give to Charis Classen who generously assisted me with many long, very hot and tedious field procedures. I especially wish to thank my family for being so loving and supporting through out all phases of this project. My parents, Jerry and Sandi Scolari, were invaluable with their contributions in the development of the methods and in their tolerance of me invading their home with charate and smokers. My father in-law, Thomas Streed, who was kind enough to edit a very rough first draft and most of all I'd like to thank my loving husband, Bob, and son, Lincoln, for all their support and patience. 


\section{TABLE OF CONTENTS}

LIST OF TABLES...............................................................

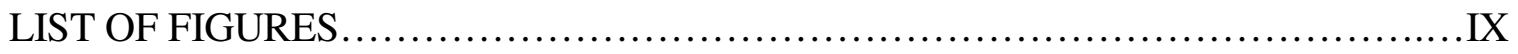

\section{CHAPTER}

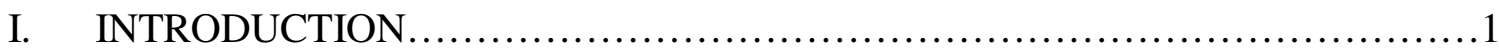

PROJECT OVERVIEW .........................................................

PROJECT SITE DESCRIPTION ...........................................

VEGETATION OF ROCKY CANYON.......................................... 6

Foothill Woodland................................................ 6

Riparian.................................................................

Coastal Scrub....................................................

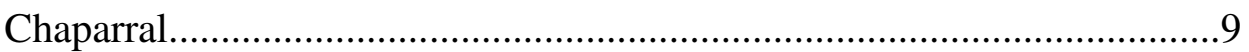

FIRE ECOLOGY IN CHAPARRAL.....................................................................12

MINING OPERATIONS AT ROCKY CANYON QUARRY ...........................................14

LEGISLATIVE REQUIREMENTS......................................................................

RESTORATION AND REVEGETATION GOALS......................................................19

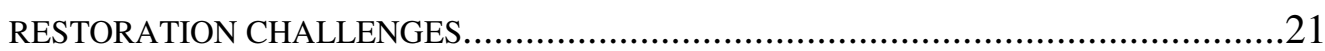

SEED DORMANCY AND DORMANCY BREAKING TREATMENTS.............................26

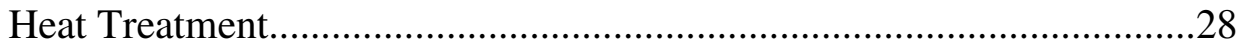

Acid Scarification Treatment...................................................................29

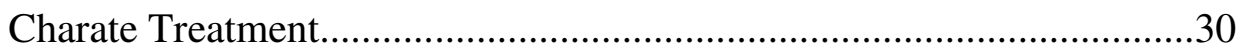

Smoke Treatment..................................................................................

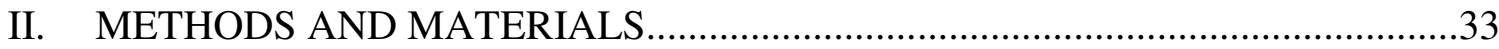

PROJECT SITE AND TEST PLOT DESIGN.............................................................3

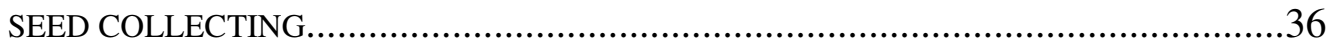

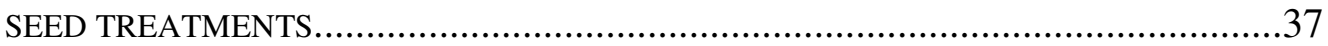

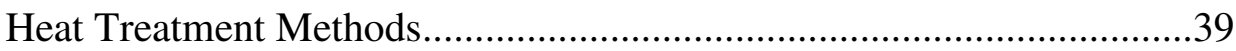

Sulfuric Acid Soak Treatment Methods.....................................................40

Smoke Treatment Methods.................................................................... 


\section{TABLE OF CONTENTS CONTINUED}

Liquid Smoke Soak...............................................................41

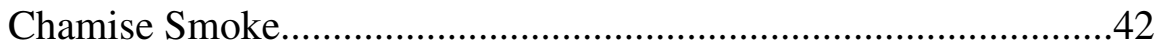

Liquid Smoke Field...............................................................44

Charate Treatment Methods.............................................................44

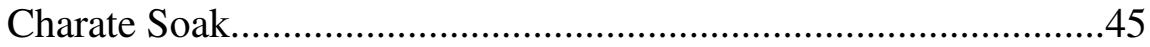

Charate Field........................................................................46

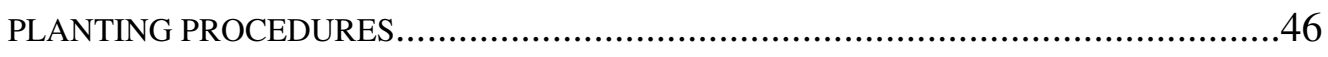

SAMPLING AND MONITORING.......................................................... 47

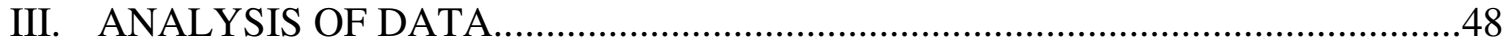

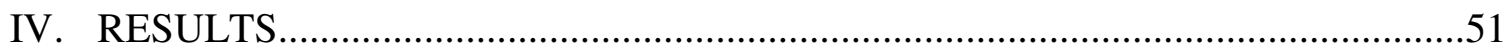

GERMINATION RESULTS.................................................................. 51

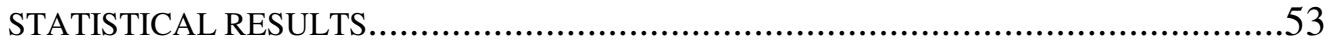

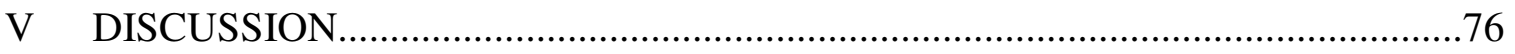

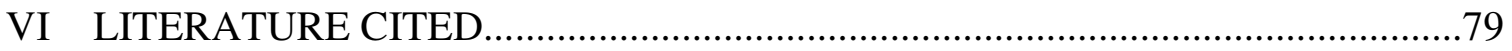
APPENDICES

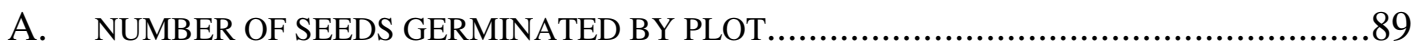

B. STATISTICAL ANALYSES: MINITAB OUTPUT ................................................92

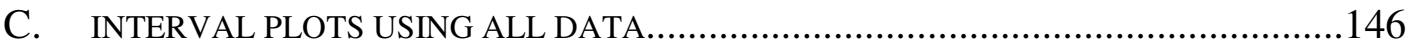




\section{LIST OF TABLES}

Table $\quad$ Page

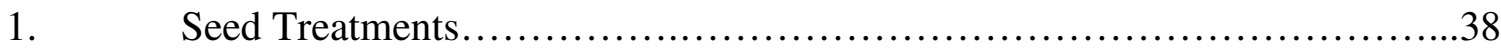

2. 2002-2003 Treatments Found to be the Best and Insignificantly Different from the Best..............................................54

3. 2003-2004 Treatments Found to be the Best and Insignificantly Different from the Best...........................................55

4. Second 2003-2004 Treatments Found to be the Best and Insignificantly Different from the Best...........................................56

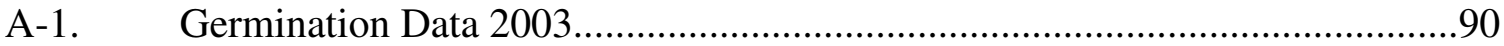

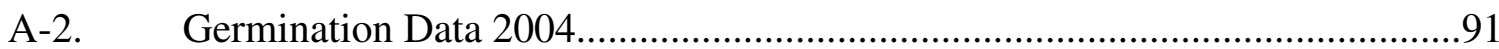


Figure

\section{LIST OF FIGURES}

1. Location of Rocky Canyon Granite Mine................................2

2. Average Weekly High and Low Temperatures during the 2002-2003

Experiment..................................................

3. Average Weekly High and Low Temperatures during the 2003-2004

Experiment...................................................4

4. Precipitation Amounts during the 2002-2003 Rain Season...................5

5. Precipitation Amounts during the 2003-2004 Rain Season....................5

6. Plant Communities Found within the Rocky Canyon Quarry..................6

7. Finished Slopes within the Rocky Canyon Granite Quarry. ..................17

8. Location of the Experimental Plots within the Rocky Canyon Granite

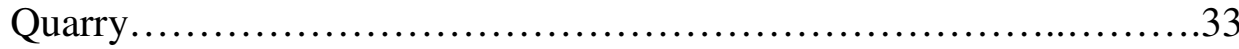

9. Experimental Test Plot........................................... 35

10. Overview of the 2003-2004 Experimental Test Plots........................35

11. Holes Cut into the Top of the Smoker..................................43

12. Smoker Set Up. ................................................43

13. Chamise Cotyledons in a 2003- 2004 Experimental Plot....................47

14. Number of Seeds Germinated in the 2002-2003 Experimental Season by Treatment......................................................51

15. Number of Seeds Germinated in the 2003-2004 Experimental Season by

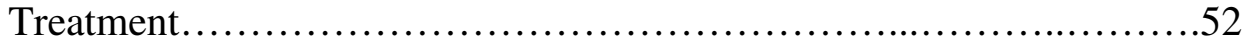

16A-16B. Comparison of Seeds Germinated Without and With Heat.....................57

17A-17B. Comparison of Seeds Germinated Without and With Charate Soak.............58

18A-18B. Comparison of Seeds Germinated Without and With Charate Field............58

19A-19B. Comparison of Seeds Germinated Without and With Liquid Smoke Soak....59 


\section{LIST OF FIGURES}

Figure

Page

20A-20B. Comparison of Seeds Germinated Without and With Liquid Smoke Field....60

21A-21B. Comparison of Seeds Germinated Without and With Chamise Smoke.........61

22A-22B. Comparison of Seeds Germinated Without and With Sulfuric Acid Soak.....62

23A-23B. Interaction between Heat and Charate Soak Treatments.....................62

24A-24B. Interaction between Heat and Charate Field Treatments......................63

25A-25B. Interaction between Heat and Liquid Smoke Soak Treatments..................64

26A-26B. Interaction between Heat and Liquid Smoke Field Treatments.................64

27A-27B. Interaction between Heat and Chamise Smoke Treatments.....................65

28A-28B. Interaction between Heat and Sulfuric Acid Soak Treatments................66

29A-29B. Interaction between Charate Soak and Liquid Smoke Soak Treatments........67

30A-30B. Interaction between Charate Soak and Liquid Smoke Field Treatments.......68

31A-31B. Interaction between Charate Soak and Chamise Smoke Treatments...........69

32A-32B. Interaction between Charate Soak and Sulfuric Acid Soak Treatments........70

33A-33B. Interaction between Charate Field and Liquid Smoke Soak Treatments.......71

34A-34B. Interaction between Charate Field and Liquid Smoke Field Treatments........72

35A-35B. Interaction between Charate Field and Chamise Smoke Treatments...........73

36A-36B. Interaction between Charate Field and Sulfuric Acid Soak Treatments.........73

37A-37B. Interaction between Liquid Smoke Soak and Sulfuric Acid Soak

Treatments................................................... 74

38A-38B. Interaction between Liquid Smoke Field and Sulfuric Acid Soak

Treatments.............................................. 74

39A-39B. Interaction between Chamise Smoke and Sulfuric Acid Soak Treatments......75 


\section{LIST OF FIGURES IN APPENDIX C}

Figure

Page

1A-1B. Comparison of Seeds Germinated Without and With Charate Soak Using All Data....

2A-2B. Comparison of Seeds Germinated Without and With Charate Field Using All Data.

3A-3B. Comparison of Seeds Germinated Without and With Liquid Smoke Soak Using All Data...

4A-4B. Comparison of Seeds Germinated Without and With Liquid Smoke Field Using All Data............................................... 148

5A-5B. Comparison of Seeds Germinated Without and With Chamise Smoke Using All Data..................................................148

6A-6B. Interaction between Heat and Charate Field Treatments Using All Data......148

7A-7B. Interaction between Heat and Charate Soak Treatments Using All Data.....149

8A-8B. Interaction between Heat and Liquid Smoke Soak Treatments Using

All Data.

9A-9B. Interaction between Heat and Liquid Smoke Field Treatments Using

All Data...

10A-10B. Interaction between Heat and Chamise Smoke Treatments Using

All Data....

11A-11B. Interaction between Charate Soak and Liquid Smoke Soak

Treatments Using All Data...

12A-12B. Interaction between Charate Soak and Liquid Smoke Field Treatments Using All Data.

13A-13B. Interaction between Charate Soak and Chamise Smoke Treatments

Using All Data...

14A-14B. Interaction between Charate Soak and Sulfuric Acid Soak Treatments

Using All Data... 


\section{LIST OF FIGURES IN APPENDIX C}

$\begin{array}{lll}\text { Figure } & \text { Page }\end{array}$

15A-15B. Interaction between Charate Field and Liquid Smoke Soak Treatments

Using All Data....................................................151

16A-16B. Interaction between Charate Field and Liquid Smoke Field Treatments

Using All Data................................................. 152

17A-17B. Interaction between Charate Field and Chamise Smoke Treatments

Using All Data.................................................. 152

18A-18B. Interaction between Charate Field and Sulfuric Acid Soak Treatments

Using All Data.....................................................152

19A-19B. Interaction between Liquid Smoke Soak and Sulfuric Acid Soak Treatments

Using All Data.................................................. 153

20A-20B. Interaction between Liquid Smoke Field and Sulfuric Acid Soak Treatments

Using All Data.................................................. 153

21A-21B. Interaction between Chamise Smoke and Sulfuric Acid Soak Treatments

Using All Data................................................... 153 


\section{CHAPTER I INTRODUCTION}

\section{PROJECT OVERVIEW}

Rocky Canyon Granite Quarry is a hard rock granite mine in which the disturbance created by the excavation of granite from the slopes results in the loss of vegetation, topsoil, subsoil as well as the rock material below. Reclamation of the mined land is necessary to prevent or minimize adverse environmental effects and to protect public health and safety. Reclamation includes revegetation of mined areas and restoration of natural ecosystems that are near pre-disturbed conditions. My project compares methods and techniques in which seed germination and establishment of chamise (Adenostoma fasciculatum) can be enhanced on the restored slopes of Rocky Canyon Quarry. Chamise is the dominant species found in chaparral communities at Rocky Canyon prior to mining.

\section{PROJECT SITE DESCRIPTION}

Rocky Canyon Granite Quarry is located in a narrow, isolated canyon in San Luis Obispo County about five miles east of the City of Atascadero, California (Figure 1). The quarry is situated in the western fringe of the Santa Lucia Mountains, one of a series of mountains within the interior South Coast Ranges of California. Rocky Canyon is a relatively flat valley bordered by steep, granite hillsides on both its north and south sides. 


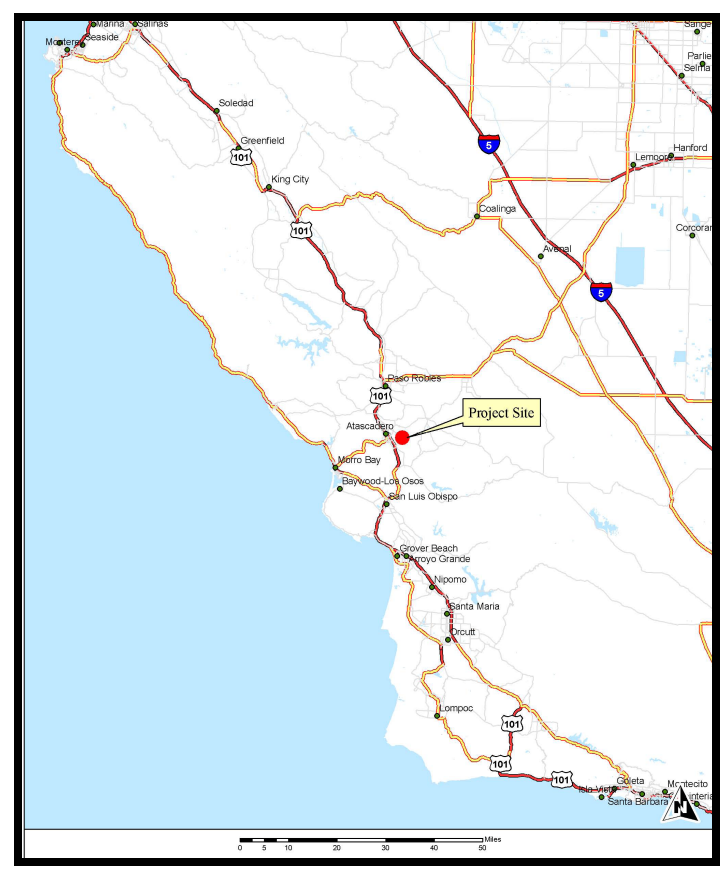

Figure 1. Location of Rocky Canyon Granite Mine

Elevations range from approximately 1,000 feet above sea level in the canyon floor to 1,600 feet along the eastern ridgeline. Rocky Canyon Creek is a seasonal creek that flows through the canyon in an east to west direction toward the Salinas River. Rocky Canyon Road, which has a locked gate at the entrance to the quarry, traverses Rocky Canyon Quarry, generally paralleling Rocky Canyon Creek, and continues through the canyon eastward toward Creston, CA. Recreational activities such as hiking, horseback riding, and mountain biking are permitted along this section of Rocky Canyon Road, but no public auto traffic is allowed through the quarry.

Rocky Canyon is underlain entirely by weathered to fresh, pervasively jointed Mesozoic intrusive granitic rock. The depth of weathering of the granite varies from approximately $80 \mathrm{ft}$ beneath ridges to $30 \mathrm{ft}$ beneath side slopes (Greiner, Inc. 1994). Soils tend to have low nutrient availability particularly with regard to nitrogen and phosphorus (Bradshaw and Chadwick 1980, Claassen and Marler 1998, Claassen and Zasoski 1998). 
In addition to low nitrogen and phosphorus levels, there is little breakdown of organic matter in granitic soils (Bradshaw and Chadwick 1980). Low levels of clay and little organic matter result in low water holding capacity, which con result in poor root development and reduced vegetative growth, particularly for young plants. However, drought tolerant, mature plants have extensive, deep root systems that can draw water from fractures in weathered rock. Mature tree and scrub roots often extend many meters into weathered rock substrate, usually following fracture planes (Johnson-Maynard et al. 1994, Jones and Graham, 1993).

Rocky Canyon has a Mediterranean warm summer climate with mild, wet winters and warm dry summers. High daily air temperature between October 2002 and May 2003 (first year of experimental plots) ranged from $46^{\circ}$ Fahrenheit $(\mathrm{F})$ to $95^{\circ} \mathrm{F}$, with an average of $66.3^{\circ} \mathrm{F}$. Low daily air temperature for the same time period ranged between $22^{\circ} \mathrm{F}$ and $59^{\circ} \mathrm{F}$, with an average of $39.7^{\circ} \mathrm{F}$. High daily air temperature between October 2003 and May 2004 (second year of experimental plots) ranged from $46^{\circ} \mathrm{F}$ to $97^{\circ} \mathrm{F}$, with an average of $68.5^{\circ} \mathrm{F}$. Low daily air temperature for the same time period ranged between $23^{\circ} \mathrm{F}$ to $53^{\circ} \mathrm{F}$, with an average of $38.3^{\circ} \mathrm{F}$. Figures 2 and 3 show the variation in temperatures over the period of my study in more detail.

Precipitation typically occurs between October and May, falling almost entirely as rain. Total rainfall at Rocky Canyon was 16.81 inches from September 2002-June 2003 and 10.78 inches from September 2003-June 2004 (Figures 4 and 5). Precipitation and air temperature were estimated from data collected from the California Irrigation Management Information System-Atascadero Station (CIMIS \#163) at the Chalk 
Mountain Golf Course in Atascadero, California (Latitude: 35 deg 28 min N; Longitude: $120 \mathrm{deg} 39 \mathrm{~min}$ W), which is 1.8 miles west of Rocky Canyon Granite Quarry.

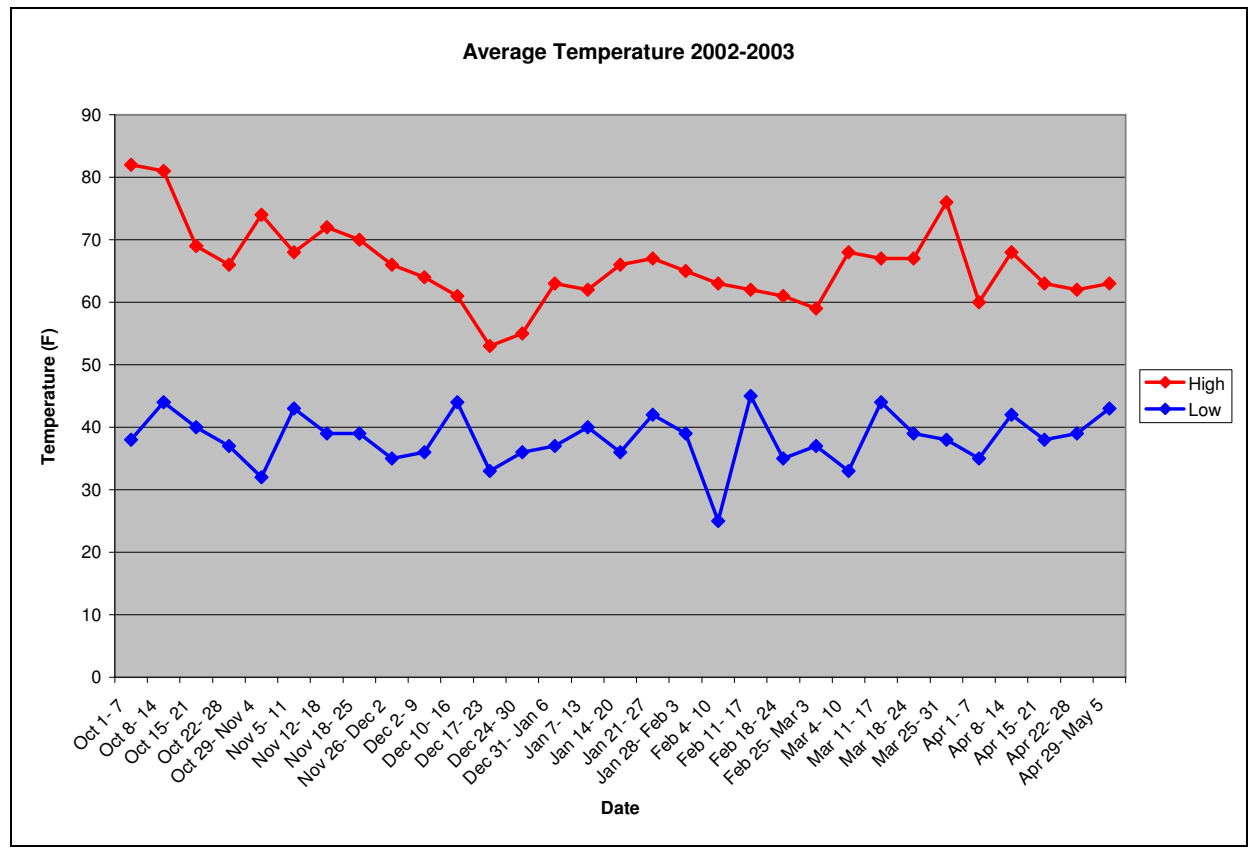

Figure. 2. Average Weekly High and Low Temperatures During the 2002-2003 Experiment.

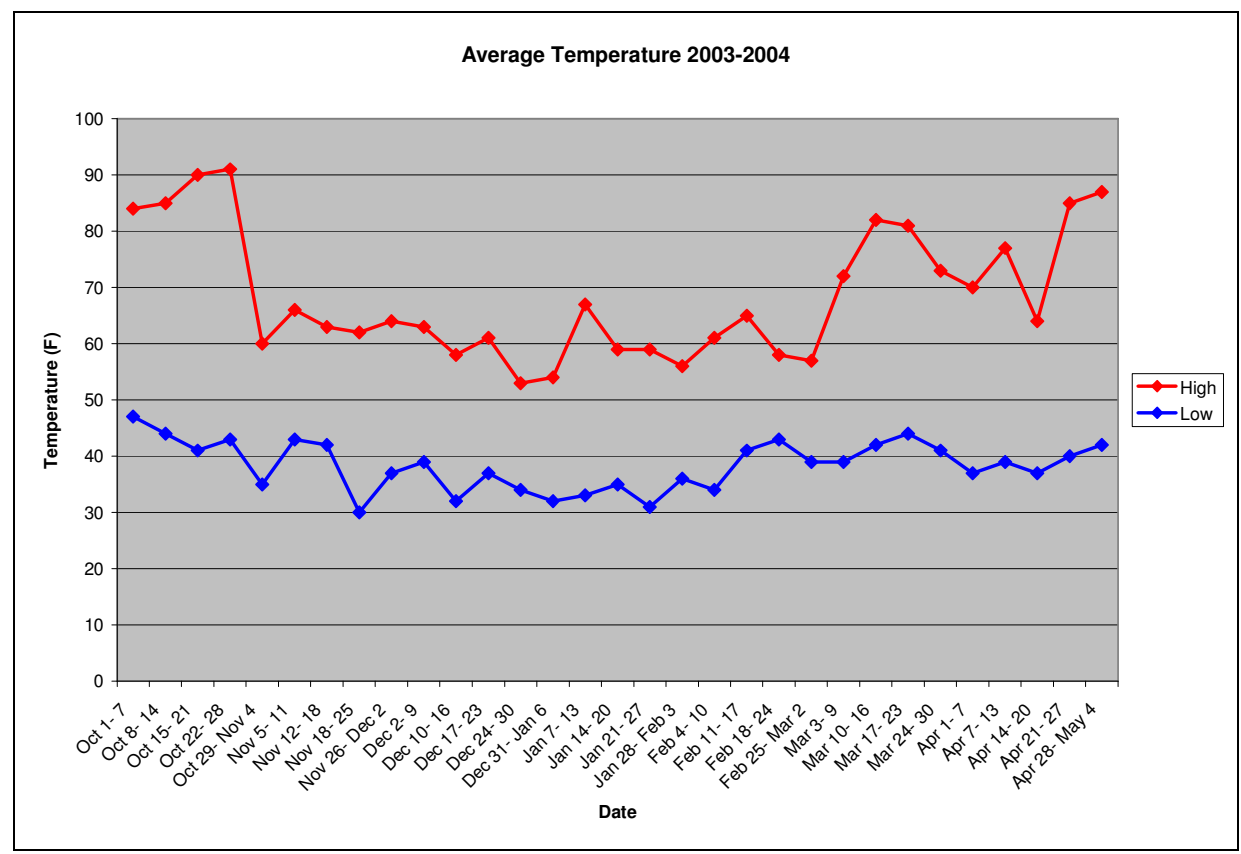

Figure 3. Average Weekly High and Low Temperatures During the 2003-2004 Experiment. 


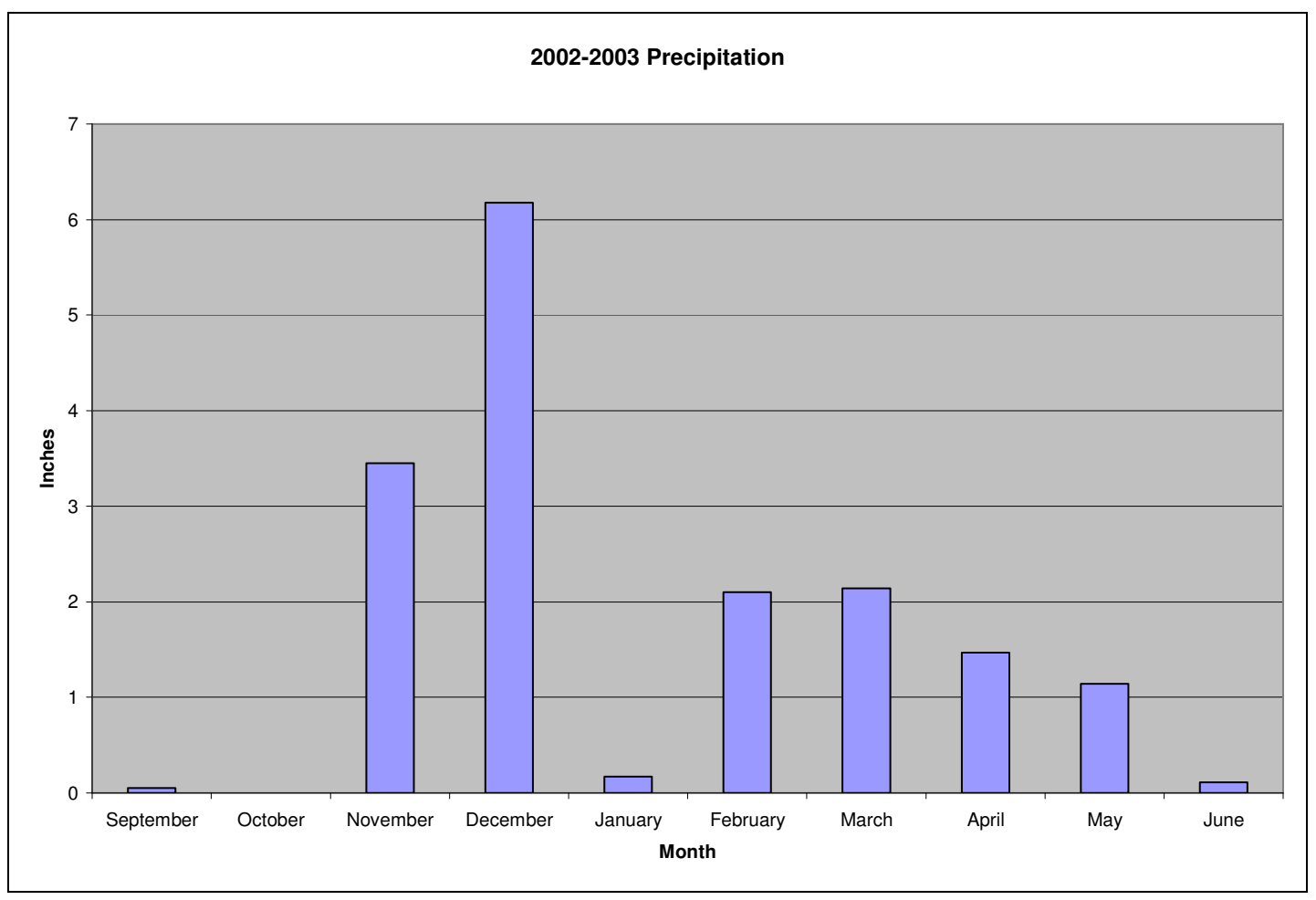

Figure. 4. Precipitation Amounts during the 2002-2003 Rain Season.

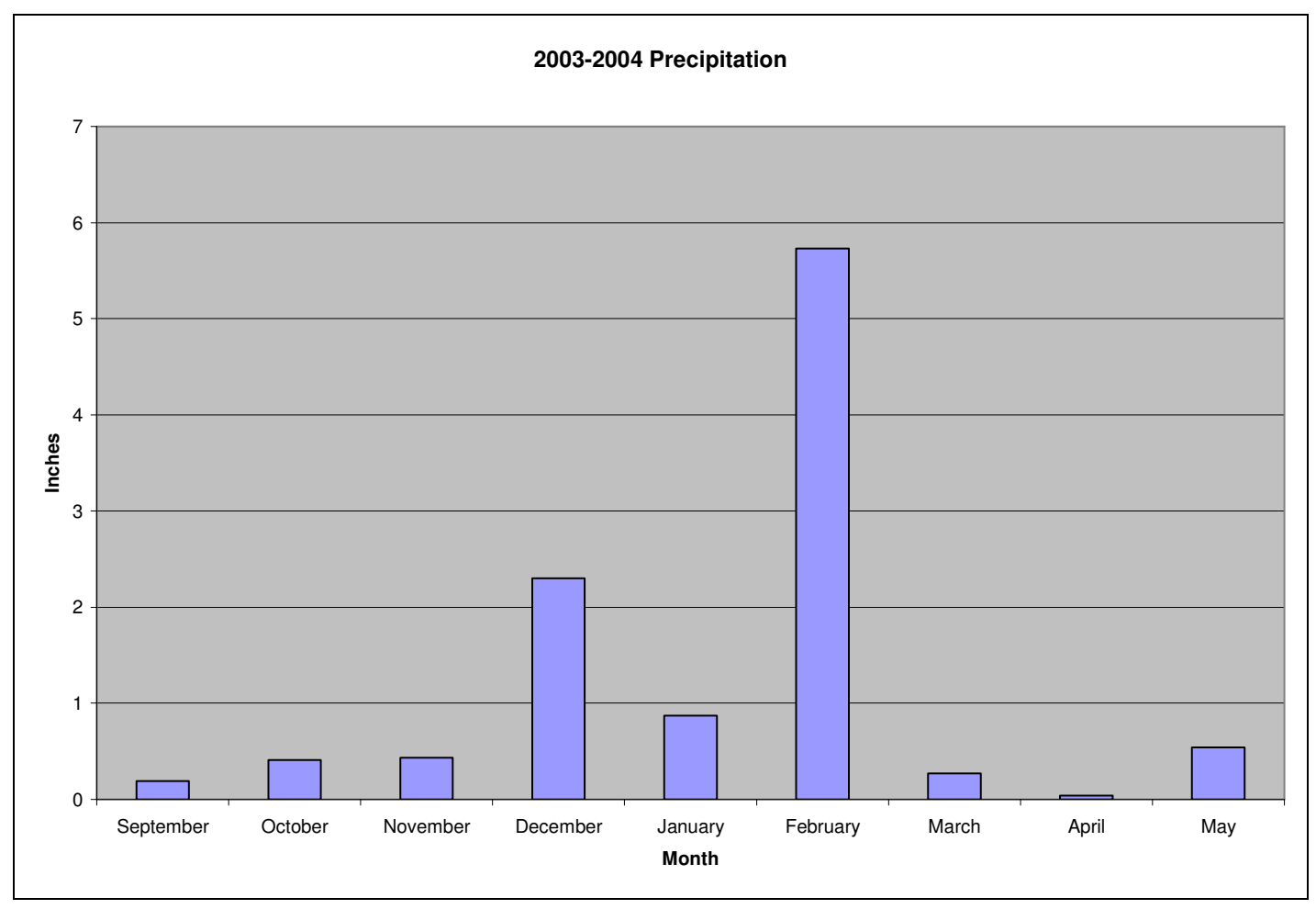

Figure 5. Precipitation Amounts during the 2003-2004 Rain Season. 


\section{VEGETATION OF ROCKY CANYON}

The vegetation cover in Rocky Canyon can be divided into four plant communities: foothill woodland, chaparral, coastal scrub and riparian (Figure 6). Of these, only the first three are found within the excavation limits of the quarry. Prior to mining, chaparral and foothill woodland covered most of Rocky Canyon Quarry. Chaparral covered approximately 54\% (140 acres), foothill woodland approximately 30\% (79 acres), coastal scrub, which was found in scattered patches mostly on disturbed sites once dominated by chaparral, covered about 4\% (10 acres), and riparian woodland about 2\% (5 acres) (Holland 1996). The four plant communities are briefly described below.

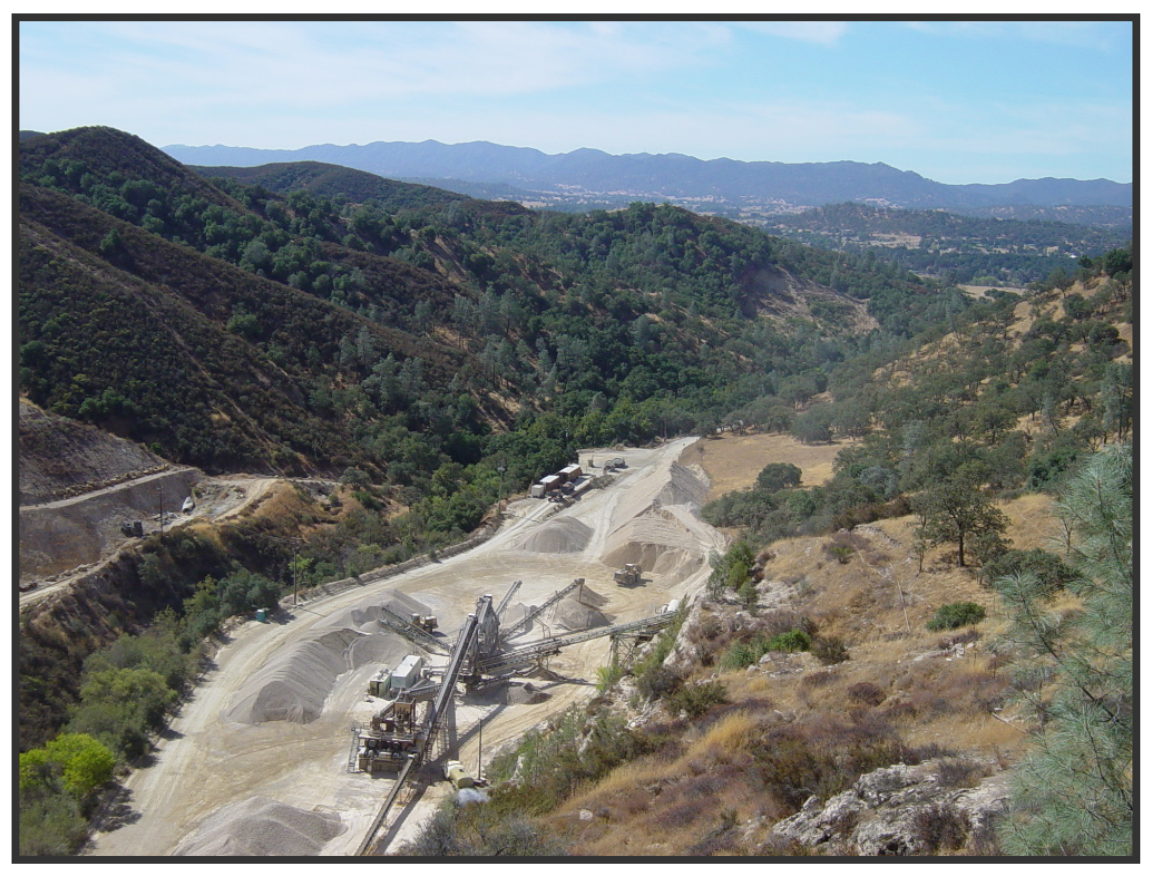

Figure 6. Plant communities found within the Rocky Canyon Quarry.

\section{Foothill Woodland}

In Rocky Canyon, foothill woodland communities are found primarily on the gentle slopes and canyons. This community is dominated by blue oak (Quercus douglasii), coast live oak (Quercus agrifolia), and foothill pine (Pinus sabiniana) with an understory of 
grasses, forbs, and shrubs. Coast live oaks are typically the dominants along canyons, north facing slopes, and moist sites, while blue oaks are typically the dominants in more exposed areas. Foothill pines grow with both oaks but are more commonly associated with blue oaks. Valley oaks (Quercus lobata) are also present in Rocky Canyon on deeper soils and as a component of the riparian woodlands.

\section{Riparian}

Riparian communities are found along drainage channels, streams, lakes, marshes, and other waterways where the vegetation has access to the shallow water table. These communities are composed of hydrophytic species that require a perennial supply of water. In Rocky Canyon, riparian vegetation is found primarily along Rocky Canyon Creek. Common trees along the creek include valley oak, arrow willow (Salix lasiolepis), yellow willow (Salix laevigata), black cottonwood (Populus trichocarpa), and sycamore (Platanus racemosa). The understory is composed of a variety of shrubs, woody vines and herbs including: cream bush (Holodiscus discolor), fuchsia-flowered gooseberry (Ribes speciosum), wild rose (Rosa californica), elderberry (Sambucus mexicana), snowberry (Symphoricarpes spp.), mugwort (Artemisia douglasiana), miner's lettuce (Claytonia perfoliata), wood ferm (Dryopteris arguta), common bedstraw (Galium aparine), and hedge nettle (Stachys bullata).

\section{Coastal Scrub}

Coastal scrub communities are composed of a mixture of soft-wooded shrubs that are approximately six feet (two meters) or less in height (Holland and Keil 1995) and 
have little understory vegetation. The herbage of the dominant plants is often glutinous or resinous and may be pungently scented with volatile oils. The dominant plants are mostly soft stemmed shrubs or suffrutescent herbs that have thin, summer deciduous leaves (Holland and Keil 1995).

At Rocky Canyon, the coastal scrub species grow in soils that are typically too rocky, dry, and infertile to support foothill woodland species (Holland 1996). While coastal scrub is not common in Rocky Canyon, scattered, small stands occur on and around the site. In addition, coastal scrub is generally the first scrub community to colonize the steep slopes following disturbances. Species typical of coastal scrub are known to colonize slopes before chaparral species because they are smaller in stature, grow faster, and have lighter wind dispersed seeds (Keeley and Keeley 1984). This community continues to grow at the Rocky Canyon Quarry due to its natural ability to invade disturbed areas and the practice of utilizing coastal scrub species in restoration efforts.

Within the limits of the quarry, the coastal scrub community is scattered forming a patchy vegetation cover on some of the steep, recently disturbed hillsides. The dominant shrubs are California sagebrush (Artemisia californica), black sage (Salvia mellifera), California buckwheat (Eriogonum fasciculatum), sticky monkey flower (Mimulus aurantiacus), deer weed (Lotus scoparius), and coyote brush (Baccharis pilularis). In most coastal scrub areas in Rocky Canyon, non-native annual grasses and forbs such as foxtail fescue (Vulpia myuros), yellow star thistle (Centaurea solstitialis), wild oats (Avena sp.), smooth cat's ears (Hypochaeris glabra) and red brome (Bromus madritensis 
ssp. rubens) typically grow in open areas among the shrubs, but in stands with a dense shrub cover, the herb layer is often poorly developed or absent.

\section{Chaparral}

Because over half of Rocky Canyon Quarry is covered by chaparral, it is imperative that a considerable portion of the revegetation efforts are focused on the reestablishment of this community. The undisturbed chaparral communities in Rocky Canyon Quarry are dominated by chamise; therefore, our restoration efforts attempt to reestablish chamisal chaparral communities to replace the chaparral removed and also to blend in with the surrounding undisturbed ecosystems. As a result, the focus of my studies is on the restoration and reestablishment of chamisal chaparral on the mined slopes. A discussion of chamise is included below following a general chaparral description.

Throughout California chaparral dominates much of the landscape between coastal scrub vegetation at lower elevations and woodlands at higher elevations (Hanes 1977). Chaparral characteristically forms a nearly continuous cover of closely spaced scrubs four to twelve feet (1.5-4 meters) tall. The dominant scrubs are evergreen, with small sclerified, heavily cutinized leaves (Cooper 1922).

In Rocky Canyon, chaparral, like coastal scrub, is found on slopes that have rocky to gravelly soils that are too hot and dry to support foothill woodland species (Holland 1996). Chaparral covered approximately $54 \%$ of Rocky Canyon Quarry prior to mining where it was the characteristic vegetation on the steep, exposed hillsides that surround the quarry (Holland, 1996). While the species composition and structure in the chaparral vary, in general the most common chaparral shrub in Rocky Canyon is chamise 
(Adenostoma fasciculatum). In many areas, chamise is virtually the only shrub present. This type of chaparral community is sometimes referred to as chamisal chaparral. Other shrubs scattered with in the chaparral include buckbrush (Ceanothus cuneatus), bush poppy (Dendromecon rigida) and bigberry manzanita (Arctostaphylos glauca) (Holland 1996). The understory is typically minimal in dense mature chaparral. At Rocky Canyon the few understory species include exotic grasses such as wild oats (Avena spp.), soft chess brome (Bromus hordeaceus), red brome (Bromus madritensis var. rubens), as well as native grasses such as melic grass (Melica imperfecta) and needlegrass (Nassella spp.).

Chamise is the most characteristic and widely distributed chaparral species in California (Dayton 1931, Hanes 1965, Sampson and Jesperson 1963). Chamise is found in approximately 70 percent of all California chaparral (Bolsinger 1989, Hanes 1971). The term chamisal is applied when $80 \%$ or more of a chaparral stand is composed of this species (Holland and Keil 1995). It is most often associated with hot, xeric sites (Hanes 1981) over a wide range of elevations, soils, latitudes, and distances from the coast (Hanes 1982). Sites supporting chamise commonly receive between 10 and 40 inches of annual precipitation, and have a temperature range from 32 to 100 degrees Fahrenheit (Hedrick 1951). Such stands usually have shallow, rocky soils with a southern aspect (Griffin 1974, Horton 1960).

Chamise is a diffusely branched, unarmed, resinous, native shrub from two to 12 feet (0.6-3.5 m) tall (Munz 1973, Van Dersal 1938). The many slender stems are erect and generally lack permanent branches (Hanes 1965). Young stems have reddish bark which becomes gray and shredded with age (Hanes 1965, Munz 1973). Linear, needlelike leaves occur in alternate fascicles along the stem (Conrad 1987, Sampson and Jesperson 1963). 
Leaves are 0.25 inch $(0.6 \mathrm{~cm})$ long, sharp-pointed, heavily sclerified, and evergreen (Conrad 1987, Hanes 1965, Keeley 1977). Although rooting habit is variable (Kummerow et al. 1977, Miller 1982), roots are usually deeply penetrating, multibranched, and wide-spreading (Hanes 1965, Hellmers et al. 1955). The root system is extensive in relation to the crown (Kummerow et al 1982, Kummerow et al 1977). Chamise typically develops several taproots, which may penetrate fractured rock to depths of 10 to 12 feet (3.0-3.7 m) (Hanes 1965).

Longevity of chamise is estimated at 100 to 200 years (Horton 1949, Keeley 1981, Rundel 1982). It reproduces both sexually and vegetatively. Chamise rejuvenates its crown by continually producing new sprouts from an underground, established lignotuber (Hedrick 1951, Keeley 1987, Keeley et al. 1986). Following disturbances, such as fire or cutting, chamise sprouts vigorously from surviving adventitious buds on the lignotuber (Howe 1981, Sampson 1944). The inconspicuous, bisexual flowers are white and occur in showy, 1 to 4 inch $(2.5-10 \mathrm{~cm})$ long terminal clusters (Dale 1986, Sampson and Jesperson 1963). The fruit is an achene (Munz 1973, Van Dersal 1938). Chamise produces a dimorphic seed population composed of dormant as well as readily germinable seeds (Christensen and Muller 1975 a, Stone and Juhren 1953). Although seed crop is abundant, the majority of the seeds are not filled and viability is quite low, in some cases 0 to $4 \%$ (Hanes 1965, Keeley 1987, Mirov and Kraebel 1937, Stone and Juhren 1953).

Under natural conditions, dormant seeds accumulate in the soil until stimulated by fire to germinate (Keeley 1981, Stone and Juhren 1953). Chamise seeds are unpalatable and seedbanks apparently are not subject to heavy predation (Reid and Oechel 1984). 
Consequently, chamise seed densities increase over time (Zammit and Zedler 1988). Seed density in the seedbank beneath 9-year-old stands has been estimated at 2,000 seeds per square meter while in 85-year-old stands, seed density was approximately 21,000 seeds per square meter (Wirtz 1977). Abundant germination from soil-stored seed occurs during the first rainy season after fire; germination during the second year is uncommon (Horton and Kraebel 1955, Keeley 1984, Reid and Oechel 1984). Although emergent seedling populations are quite high (Hanes and Jones 1967), mortality is substantial during the first several years (Hanes 1971, Horton and Kraebel 1955, Sampson 1944).

\section{FIRE ECOLOGY IN CHAPARRAL}

Fire plays a critical role in structuring many plant communities, including grasslands, shrublands, savannas, woodlands and closed forest (di Castri and Mooney 1973, Kozlowski and Ahlgren 1974, Purdie and Slatyer 1976, Gill et al. 1981, Christenson 1985, Goldammer 1990). In climates that are characterized by high temperatures that coincide with the dry season, fires are frequent and recurring. Plants living in these areas today are, at least in some part, a result of rigorous selection by fire. Those plants, which through their genetic make-up were pre-adapted to the stringent conditions of the environment, form the vegetation cover (Sweeney 1956). A phenomenon common to many of these communities is the flush of germination and growth that follows a burn (Sampson 1944, Specht et al. 1958, Vogl and Schorr 1972, Naveh 1973). Seeds accumulate in the soil's seed bank where deep dormancy delays germination until triggered by fire (Keeley and Foteringham1998). 
This post-burn recruitment is especially striking in chaparral. It has been suggested that fire has been a dominate force in chaparral development for at least the past two million years (Axelrod 1958). The resinous foliage, numerous woody stems, accumulated litter, and standing dead branches combine to make chaparral shrubs highly flammable, particularly during the dry season (Holland and Keil 1995). These characteristics result in intense, fast-spreading, potentially large fires, which have an increased probability of occurring as a stand matures (Philpot 1977).

Many chaparral species, including chamise, have developed characteristics that not only survive fire but incorporate fire into its life cycle; for instance, lignotubers that resprout and seedling recruitment that flourishes the first year after the fire (Holland and Keil, 1995). After this first year pulse, seedling recruitment is rare until the next fire (Keeley 1987) and decades often pass before some of the species are evident again (Sampson 1944, Sweeney 1956, Keeley et al. 1981, Keeley and Keeley 1988).

Typically fires in chaparral kill all above ground biomass but much of the biomass below ground (e.g.: roots, lignotubers, seeds) survives (Keeley 1987). In the first growing season after a fire the high seedling populations are derived from a previously dormant soil seed bank (Sweeney 1956, McPherson and Muller 1969, Christensen and Muller 1975 a, Keeley et al. 1985, Keeley 1987, Parker 1987) in which the fire seems to play a critical role in stimulating germination (Keeley 1987). Many chaparral species with refractory seeds have evolved barriers to germination that are normally overcome only by fire-related cues. Dormancy maybe regulated by any of a number of factors, such as impermeable seed coat, chemical inhibitors, or immature embryos (Sweeney 1956). In chaparral, seeds present in the soil seed bank during a fire are subjected to a suite of 
germination cues provided by burning, including heat, chemical effects of charred wood and smoke, and removal of alleotoxins (Parker and Kelly 1989, Keeley and Keeley 1989, Keeley 1991, Thanos and Rundel 1995). Research has shown that chamise utilizes one, or a combination of cues, to trigger the germination of its dormant seed bank.

\section{MINING OPERATION AT ROCKY CANYON QUARRY}

Mining of granite from the Rocky Canyon Quarry, and others granite quarries, provides products essential for the needs and continued economic well-being of the state. Construction aggregate is rock material crushed to various sizes. At the beginning of the 20th century, the U.S. production of crushed stone was relatively small, and its uses limited. Today, natural construction aggregate is one of the most abundant and widely used natural resources. Construction aggregate is produced in all 50 states and comprises more than half the volume of all mining in the United States (Bolen 2005, Tepordei 2005). Aggregates range in size from large boulders (rip rap), used as fill in large construction projects, to finely ground flour-sized particles used in paint, glass, plastic, medicine, and many other industrial and household products (State of Wyoming n.d.). Construction aggregates are also used in concrete and asphalt which compose most of our streets and highways (State of Wyoming n.d.).

For over 65 years, Rocky Canyon Granite Quarry has been producing a variety of construction aggregates. Starting in the 1940's, a modest operation furnished base material for San Luis Obispo County road crews and California state road projects. Currently, Rocky Canyon Granite Quarry is one of seven active mines in the San Luis Obispo-Santa Barbara region that produce Portland Cement Concrete (PCC) aggregate, a 
high grade construction aggregate used to construct concrete highways, airport runways, and buildings (California Dept. of Conservation, 1989). Deposits acceptable for PCC aggregate are the rarest and most valuable of the aggregate resources (California Dept. of Conservation, 1989). The rock obtained from the Rocky Canyon Quarry can also be crushed to yield a durable rock product that meets the Caltrans and San Luis Obispo County standards for asphaltic concrete (AC) (Morro Group 1995).

Based upon the population projections and per-capita consumption, the San Luis Obispo-Santa Barbara region will require 206 million tons of aggregate before the year 2050 of which 76 million tons must be PCC-grade suitable for concrete (Morro Group 1995). Construction aggregates are the lowest priced of all mined products; therefore, transportation costs from the mine to the point of use can become the major part of their cost to the consumer. Transportation distances of even less than two miles have costs that exceed the cost of the product at the mine mouth (State of Wyoming n.d.). Therefore, it is imperative that aggregate sources be located as close to the point of use as possible. Accessibility of the Rocky Canyon Granite Quarry, as well as the nature of the rock, provides quality construction materials at reasonable cost in the San Luis Obispo-Santa Barbara County region.

The quarry assets (existing plant, mobile equipment, long term lease for excavation, and land) are currently owned by CalPortland, which operates Rocky Canyon Quarry. The aggregate products are sold to private construction companies, government agencies, and to CalPortland's own construction division.

The method for mining the granite involves a series of steps. Mining proceeds from the top of the hillsides downwards with the creation of a series of terraces. To gain access 
to unexcavated rock, vegetation and overburden (soil, rock, or other materials that lie above a natural mineral deposit or in between mineral deposits) are striped from the hillside by bulldozer. The vegetation is crushed and pushed to an inactive area of the mine where it is stockpiled until it is distributed as topsoil onto the finished slopes prior to revegetation.

If the granite is weathered and sufficiently fractured, a bulldozer can break up the rock by ripping. If the rock is too hard to be ripped, it is first loosened by a blast of remotely detonated dynamite. The excavated rock and soil is then pushed by a bulldozer over the edge of the working terrace to cascade down to a lower crusher level. The material is then moved by a front-end loader, which deposits it into the primary crusher. The primary crusher is the first stage in the processing plant where the raw material is reduced and separated by size. Through a series of conveyer belts and equipment, rock is crushed, washed, sorted and stockpiled on the canyon floor of the plant site. Front-end loaders distribute the variety of aggregate products into trucks that transport the material off site.

Once mining is completed, the mined hillsides are shaped into a series of slopes and terraces. The steepness of the slopes varies, but most slopes are approximately 2:1 with 25-foot-wide benches at 50 foot vertical slopes (Figure 17). Benches of this width are wide enough to have a drainage ditch at the toe of the slope and still have sufficient space for track propelled maintenance equipment to turn around without damaging the ditch. 


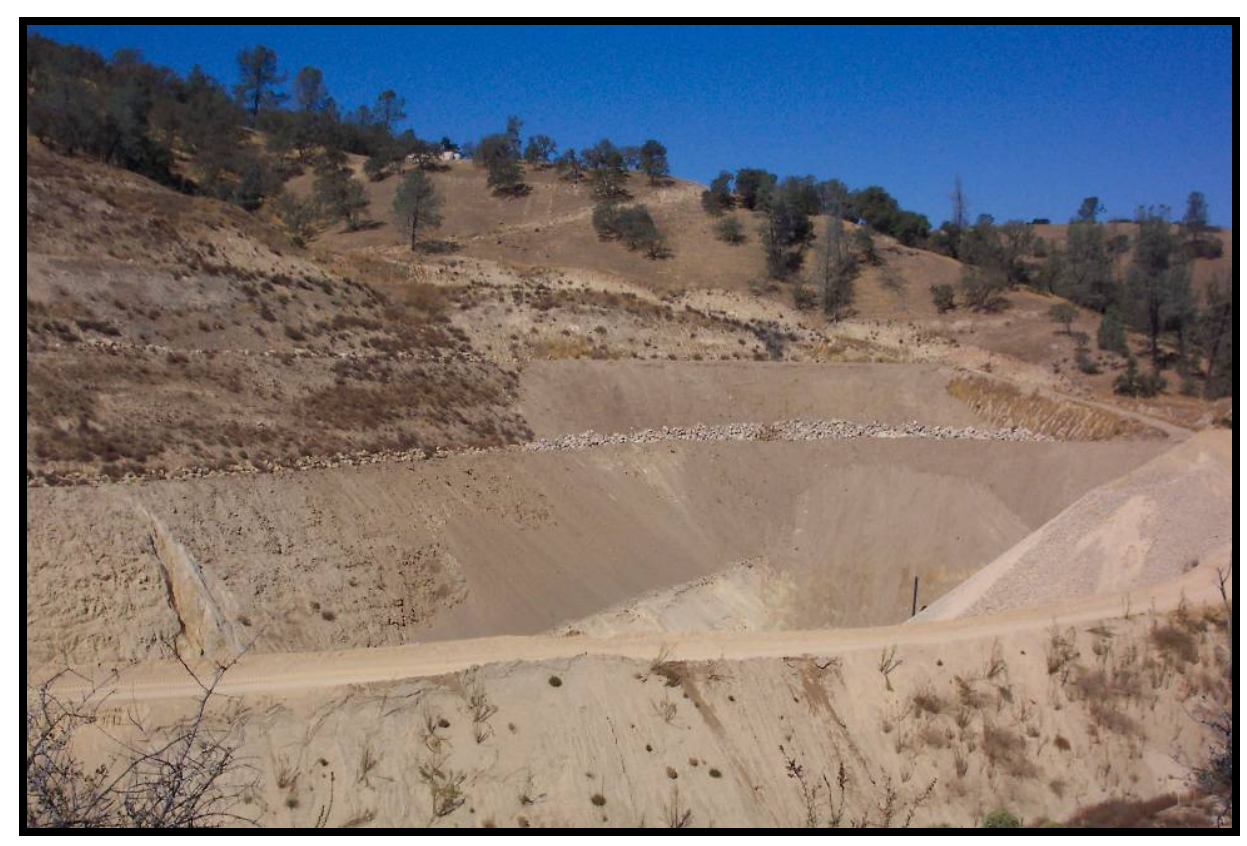

Figure 7. Finished Slopes within the Rocky Canyon Granite Quarry.

After each slope and terrace is mined and shaped, stockpiled topsoil mixed with shredded vegetation is reapplied to the finished slopes. The finished slopes are then hydroseeded and planted with native seeds and container stock plants during the fall after completion of mining.

\section{LEGISLATIVE REQUIREMENTS}

Surface mining, particularly in the construction aggregate industry, was relatively unregulated until the California legislature passed the Surface Mining and Reclamation Act (SMARA) in 1975. SMARA was enacted to address the need for a continuing supply of mineral resources and to prevent or minimize the negative impacts of surface mining to public health, property and the environment. SMARA mandates that lands disturbed by surface mining operations after January 1, 1976 be rehabilitated according to an approved reclamation plan. In 1977, the federal government followed suit with the 
passage of public law 95-87- The Surface Mining Control and Reclamation Act of 1977. To comply with permits obtained from the state and local ordinances, Rocky Canyon Granite Quarry has implemented a reclamation and restoration plan following SMARA requirements.

SMARA's standards of "Reclamation" refer to a combined process of land treatment that minimizes water degradation, air pollution, damage to aquatic or wildlife habitat, flooding, erosion, and other adverse effects from surface mining operations. The goal is to insure that mined lands are reclaimed to a usable condition, which is readily adaptable for alternate land uses and creates no danger to public health or safety.

SMARA acknowledges that surface mining takes place in diverse areas where the geologic, topographic, climatic, biological, and social conditions are significantly different. It mandates that when developing a reclamation plan, the lead agency shall consider the physical and land-use characteristics of the mined lands and their surrounding area. Prior to the initiation of mining activities, the vegetation density, cover and species richness of naturally occurring habitats are required to be documented in baseline studies. Reclamation operations and the specifications for reclamation therefore vary accordingly. Other projects involved with the reclamation of mines in California have resulted in a variety of finished landscapes ranging from agricultural strawberry fields to riparian wildlife habitats (California Department of Conservation 2006).

As the mining operation takes place, SMARA mandates that there be ongoing attempts at reclamation. During the reclamation process, available research addressing revegetation methods for the mined areas are required to be used. Test plots, conducted 
simultaneously with mining, are mandatory to determine the most appropriate planting procedures to ensure successful implementation of the proposed revegetation plan.

The Biological Sciences Department at California Polytechnic State University, San Luis Obispo (Cal Poly) has been working on the restoration and revegetation of the mined slopes since the early 1990's. In 1993, V. L. Holland developed a Restoration and Revegetation Plan for the quarry that has been implemented, with modifications, since that time.

\section{RESTORATION AND REVEGETATION GOALS}

The ultimate goal of revegetation is to reestablish natural ecosystems that will be similar to the pre-disturbed ecosystems, will blend in with the surrounding undisturbed ecosystems, and will be self-sustaining (Holland 1996). Although a disturbed site may eventually revegetate naturally, natural revegetation of an area takes many years, during which the ecosystem may severely degrade in quality. Revegetation of the disturbed slopes of Rocky Canyon, as a part of the reclamation, has many benefits including: erosion control, increased habitat for wildlife, reduced infestation by invasive plant species, and improved aesthetics.

Because the reclamation of mined granite slopes is a relativity new venture, there are no reliable reclamation techniques for the establishment of native chaparral. Consequently, results of ongoing experimental revegetation projects are essential to future efforts at the Rocky Canyon Quarry. The results obtained from the Rocky Canyon experiments and study plots may also aid reclamation plans at other granite quarries or similar restoration areas. 
Prior to the development of the reclamation plan for Rocky Canyon Quarry, initial attempts to revegetate the mined hillsides consisted of planting non-native pines (Pinus spp.) in a row on finished benches. These trees are now mature and can still be observed perched atop a sheer cliff boarding the valley floor and processing plant. Although these initial efforts resulted in some established vegetation, the long term goal of the reclamation plan at Rocky Canyon is to re-establish the pre-existing assemblage of plant species and plant communities in such a manner that they will be self-sustaining and blend in with the surrounding undisturbed vegetation.

Objectives and goals of the reclamation plan to achieve this include: (1) replacing the topsoil on the finished slopes and benches following excavation; (2) stabilizing the soil so that erosion is controlled; (3) creating habitats that will allow for the gradual invasion and establishment of the native species from the surrounding undisturbed plant communities through natural succession processes; (4) enhancing the recovery process by hydroseeding and planting native species collected from the area; (5) enhancing the biodiversity and habitat conditions along Rocky Creek; (6) ultimately ending with a native vegetation cover that is genetically and ecologically compatible with the surrounding vegetative cover both in composition and structure; and (7) reestablishing the natural regeneration of the plant community so that in its dynamic equilibrium with the surrounding plant communities (Holland 1996).

Since the vegetation will be reestablished on man-made landforms (slopes), which are not the same natural habitats that were present prior to mining, the reestablished plant communities will not be identical in structure and function as the original land. However, they must be stable and self-sustaining ecosystems that are similar to those prior to 
mining (National Academy of Science 1974). The goal of the revegetation plan for the chaparral communities is to re-establish the same areal coverage (140 acres) of chamisal chaparral on the steep finished slopes of the quarry that existed prior to mining (Holland 1996).

\section{RESTORATION CHALLENGES}

In the original revegetation plan developed for Rocky Canyon the protocol for chaparral communities utilizes the combination of topsoil, litter, and shredded brush to provide a natural source of propagules (seeds, bulbs, rhizomes) of the native, indigenous plants of the area. The expectations were that by returning these seeds to the disturbed habitat, they would germinate and the native plants will become re-established naturally.

In addition, the original revegetation plan relies on seeds from the surrounding native plant communities gradually dispersing into the disturbed sites generating a natural succession of plant species. It is anticipated that coastal scrub will occupy the site first as short lived pioneer species. These pioneer species would stabilize the slopes, modify the habitat and gradually be replaced by longer living chaparral species, which are slower to disperse, grow, and become established. To enhance this succession process, hydroseeding of the site with a combination of fast growing native herbs and perennials indigenous to the area is a principal part of the original revegetation plan. Slower growing chaparral species are also included in the hydroseed mix.

Coastal scrub species that naturally invade disturbed slopes, benches, and inactive roads are considered particularly important in the revegetation plan. Species typical of 
coastal scrub are known to be more invasive than chaparral species because of their small stature, faster growth rate and lighter wind dispersal seeds (Keeley and Keeley 1984). Lacking any innate dormancy these species readily colonize disturbed sites (Zedler 1982). Under severe disturbance, such as mining operations, coastal scrub species are capable of dominating former chaparral sites (Keeley and Keeley 1984). Coastal scrub species including sticky monkeyflower, black sage, deerweed, California buckwheat, coyote brush, and California sagebrush have been included in the hydroseed mix applied to finished slopes at Rocky Canyon Quarry to mimic the observed response to disturbances. Within the original revegetation plan, the growth and survival of these scrubs is regarded as critical to the success of the revegetation project. However, some investigators researching natural chaparral regeneration have suggested that establishing an initial coastal scrub community on the finished slopes may actually be detrimental to chaparral establishment. They report that in chamisal chaparral, fire succession involves a rapid regeneration of the previously existing cover (Keeley 1986). Following a natural disturbance such as fire, chaparral succession is unique in that it succeeds itself rather than being preceded by other vegetative types (Santa Barbara City College n.d.). One way the chaparral community achieves this autosuccession is by species regrowing from lignotubers without significant development of other taxa (Holland and Keil 1995). However, this is not applicable to mined areas on which all the lignotubers have been removed and topsoil reapplied to the slopes with only its seed bank. Another factor that promotes the autosuccession is that in the first growing season after fire, all of the pre-fire dominates are present in the form of seedlings (Keeley 1987). Regeneration is from 
residual species present prior to the fire and colonization plays a relativity minor role in the post-fire recovery (Keeley et al. 2005).

Through vigorous lignotuber sprout production (in areas where lignotubers are not removed) and the establishment of large numbers of seedlings, chamise is one of the species that is present in the community immediately after a fire and remains present in all stages of regeneration (Biswell 1961, Keeley and Zedler 1978, Sampson 1944). Typical vegetation cover on 1-year-old chamise chaparral burns also includes a high percentage of herbaceous vegetation and the seedlings and sprouts of associated shrubs and subshrubs. Although the recovering community has a high percent cover of herbaceous and short lived species, including coastal scrub species, chamise seedlings and resprouts are abundant from the beginning. In nature, chamise seedlings and resprouts grow during the first post fire decade, and herbaceous vegetation rapidly declines; likewise subshrubs and short lived shrubs are restricted to smaller and smaller openings (Florence 1987, Hanes 1982). A dense stand of chamise typically develops within approximately 8 to 10 years (Hanes 1977), with chamise frequently comprising one-third of the total cover (Hanes 1971). Stands often exhibit complete canopy closure by 22 years of age (Rundel 1982).

In situations such as Rocky Canyon Quarry where there is an absence of lignotubers, if chamise seedlings do not become established in large numbers in the pioneer community, several potential problems occur in the reestablishment of chamisal chaparral. An indicator that seedlings of chaparral shrubs are not strong competitors is apparent by examining mature stands of chamisal chaparral. Many studies have shown that in mature chaparral, seedlings occasionally establish in canopy gaps, but successful 
establishment almost never occurs directly beneath established canopy (Christensen and Muller 1975b, Hanes 1965, Keeley 1987, Keeley et al. 1985, Zedler 1977). A study of the seed bank beneath an 85-year-old stand of chamise indicated that 20 percent of the viable chamise seedbank was readily germinable (Zammit and Zedler 1988) but do not germinate under a mature shrub canopy. Successful establishment of a dense coastal scrub community might create conditions that suppress the viable chamise seeds from germinating and becoming established.

Other studies have shown that chamise is a poor competitor amongst other species as well, such as grasses and forbs. For example, ryegrass (Lolium multiflorum) is often seeded onto recently burned chaparral as a means of emergency revegetation and erosion control (Barrow and Conard 1987). However, ryegrass has been found to inhibit the growth and development of chamise seedlings (Gautier 1983), and substantially reduces postfire chamise seedling establishment (Barrow and Conard 1987, Gautier 1983). On seeded burned areas in southern California, almost no chamise seedlings became established in areas where first-year ryegrass cover ranged between 40 and 90 percent (Conrad 1979). Studies have also shown that black sage, a prominent coastal scrub species, has an inhibitory effect on chamise germination (Went, Jhuren and Juhren 1952).

Another potential problem with the original revegetation plan is the chamise seeds may not successfully disperse onto the site from the surrounding chaparral. Because chamise's small achenes are not highly specialized for wind dispersal, most seeds fall within six feet (two meters) of the parent scrub (Keeley 1987; Davey 1982). Additionally, although chamise plants produce an abundance of seeds each year, the majority of the seeds are not filled and viability is quite low. Studies have shown that as little as 0 to 4 
percent of the seeds produced are viable and capable of germinating (Hanes 1965, Keeley 1987, Mirov and Kraebel 1937, Stone and Juhren 1953). Even if a chamise seed is able to disperse across the vast bare areas formed from the mining operations, there is a low probability that it will be viable and capable of germinating.

Although seed dispersal of chamise from the undisturbed communities may not be practical, the top-soil, litter and shredded brush applied to the finished slopes may contain numerous chamise seeds. However, these seeds may require cues provided by fire to germinate. Although a small portion of chamise seed germinates under favorable moisture and temperature conditions without fire (Stone and Juhren 1953, Zammit and Zedler 1988), the majority of the viable seeds lie dormant in the soil until fire comes to them (Keeley et al. 1985). Since chamise seeds germinate at high rates only after a fire, seedling recruitment and population expansion are dependent on one or more cues related to fire, such as heat, charate, and smoke. Although the seeds may be present in the restored seed bank, the seeds will remain dormant in the soil and may not germinate unless a fire-related cue is present to trigger germination. On the other hand, coastal scrub and herbaceous species readily germinate without these cues and may dominate the site. If seeds of chaparral shrubs do not germinate, coastal scrub may persist on the slopes until the chaparral seeds are able to disperse onto the site and receive the necessary cues to germinate, and even then competition with other plants may reduce their establishment.

These anticipated problems may be resolved by adding large quantities of chamise seeds, which have received a dormancy breaking trigger, to the finished slopes. My study focused on examining different techniques that have been shown by researchers to 
increase the germination rate of chamise. With few exceptions, most information about the effects of fire on the germination of chaparral species has been provided by laboratory studies. These studies have examined the germination of seeds subjected to heat (Sweeney 1956, Christenson and Muller 1975, Keeley et al. 1985, Keeley 1987, Zammit and Zedler 1988), acid scarification (Berg 1974, Baskin and Baskin 2001, De La RosaIbarra and Garcia 1994, Godinez-Alvarez and Valiente-Banuet 1998), powered charred wood (charate) (Keeley et al. 1985, Keeley 1987, Keeley and Keeley 1987, Keeley 1992) and smoke (de Lange and Boucher 1990, Brown 1993, Baxter et al. 1994, Keeley et al. 2005, Dixon et al. 1995, Roche et al. 1997, Keeley and Fotheringham 1997, Baldwin et al. 1994). My study compares the effects of heat, sulfuric acid, charate and smoke treatments on the germination of chamise seeds on restoration slopes in the Rocky Canyon Granite Quarry. I am hopeful that one or more of the techniques studied in my research will enhance restoration efforts on the finished slopes so that the restored vegetation will resemble the plant communities that would recover after a natural fire disturbance in a chaparral community.

\section{SEED DORMANCY AND DORMANCY BREAKING TREATMENTS}

Nonrefractory seeds are those which germinate readily when planted and supplied with moisture. Refractory seeds are those which do not germinate readily under conditions presumably adequate for germination because they have impermeable seed coat, chemical inhibitors, immature embryos, or other similar conditions that reduce germination (Sweeney 1956). 
Many plant species exhibit an external dormancy which results from a seed's hard seed coat that is impervious to water and gases (Stone and Juhren 1953). The seed will not germinate until the seed coat is altered physically. The process of breaking, scratching, or mechanically altering the seed coat to make it permeable to water and gases is known as scarification. Natural occurrences that can result in scarification include a fall from a parent plant, a tumble along a creek bottom, or being crushed along a path. Scarification can also occur as seeds pass through the digestive tract of various animals or from a deep freeze in the winter (Evans and Blazich 1999).

During a fire, a physical change to the seed coat can occur from heat shock, which can melt or crack the cuticle or otherwise scarify the seed coat. Many plant species found in the fire adapted communities have seeds that require heating or other means of seed coat scarification for germination (Keeley 1991). In laboratory and greenhouse situations, scarification of the seed coat is often accomplished through an acid bath. However, for a substantial number of species with fire-triggered germination, physical alterations on the seed coat have no effect on germination; rather germination is induced by chemicals from combustion products (Keeley 1991).

Although there is not a conclusive answer, research continues to advance the knowledge of the mechanisms behind how fire-produced chemicals stimulate germination. Some studies conclude that either oxidizing gases in smoke and/or acids generated on burnt sites play a role in germination of post-fire species in chaparral (Baldwin et al. 1994, Keeley and Fotheringham 1997). One theory is that these chemicals act as internal signals and mediate germination by inducing enzymes to enhance production of growth regulators (Keeley and Fotheringham 1998). 
The specific role of fire in seed germination of chamise is still obscure. Chamise seed germination has been shown increase as a result of both physical and chemical treatments. Some studies have shown that physical and chemical treatments may act synergistically to stimulate germination (Keeley 1987). However, other studies have reported seemingly conflicting responses. For example, Stone and Juhren (1953) reported that heat alone stimulates germination of chamise seeds, while others found that it does not (Parker 1987, Keeley 1987, Keeley et al. 2005). In the following sections, I discuss the physical and chemical stimuli utilized in my study.

\section{Heat Treatment}

Heat has been shown to significantly enhance seed release and germination of numerous shrubland and sclerophyllous woodland species (Sweeney 1956, McPherson and Muller 1969, Christensen and Muller 1975a, Keeley et al. 1985, Keeley and Keeley 1987, Parker 1987). Stone and Juhren (1953) and Christensen and Muller (1975a) found that seed germination in some chaparral shrubs, including chamise, is enhanced by seed scarification by heat. Heat-shock-stimulated seed germination is common in several plant families including: Fabaceae, Rhamnaceae, Convolvulaceae, Malvaceae, Cistaceae, and Sterculiaceae (Ballard 1973, Christensen and Muller 1975a, Bewley and Black 1982, Egley 1989, Keeley 1992, Kelly et al, 1992, Thanos et al. 1992, Bell et al. 1993). While an exhaustive study of germination characteristics for taxa in these families is lacking, several investigators have found that seed dormancy is imposed by a more or less impermeable seed coat (Stone and Juhren 1953), and that heat shock melts or cracks the cuticle or otherwise scarifies the seed coat (Christenson and Muller 1975, Keeley 1987, Stone and Juhren 1953). This heat cue is not specific to fire, and soil heating on exposed 
sites, created by disturbances other than fire, can also induce germination (Keeley and Keeley 1999).

Variation in temperature has been shown to affect patterns of seedling establishment. Even species that have an increase in seed germination with heating can also be negatively affected by high temperatures (Davis et al. 1989, Moreno and Oechel 1991, D'Antonio et al. 1993, Rice 1993). Chamise is one of the species that is sensitive to high temperatures (Christenson and Muller 1975, Hanes 1974, Went et al. 1952). Studies in chaparral communities following natural fires show that seedlings are more abundant in burn areas with moderate fire intensity than in areas with high fire intensity (Moreno and Oechel 1991). Christensen and Muller (1975a) found that germination of chamise seeds are enhanced when seeds are exposed to temperatures of 160 to 180 degrees Fahrenheit for 15 minutes.

\section{Acid Scarification Treatment}

A common method of pretreating seeds with hard and impermeable seed coats is to soak them in concentrated sulfuric acid $\left(\mathrm{H}_{2} \mathrm{SO}_{4}\right)$. This treatment has been highly effective for many species of tree, shrub and forb seeds with a hard seed coat (Berg 1974, Baskin and Baskin 2001, De La Rosa-Ibarra and Garcia 1994, Godinez-Alvarez and ValienteBanuet 1998). Sulfuric acid scarification has been shown to soften the seed coat and/or remove chemical inhibitors from the testa of many taxa allowing the seeds to germinate more readily (Baskin and Baskin 2001).

Since seeds placed in concentrated sulfuric acid will be burnt and become charcoal in time, the temperature of the acid and the length of time the seeds are soaked are very important. According to California Department of Fish and Game (2001) the acid should 
be at room temperature for a period of a few minutes to several hours depending on the species. The germination of chamise seeds has been shown to be stimulated by soaking the seeds in a 10 percent sulfuric acid solution for 15 minutes (Horton 1949).

\section{Charate Treatment}

Field observations show that pyrophytic annual herbs are locally widespread in the first year after a fire; however, they become restricted to areas around charred plant remains in subsequent years (Keeley and Nitzberg 1984), because the chemicals that exist in these charred remains (charate) stimulate seed germination in several species. In the laboratory, charate was first shown to enhance significant germination of the pyrophyte Yellow Whispering Bells (Emmenanthe penduliflora) by Wicklow (1977) and Jones and Schlesinger (1980). However, it is now known that charate increases seed germination in many other species in western North America (Keeley et al. 1985, Keeley 1987, Keeley

and Keeley 1987) and South Africa (Keeley 1992). Chaparral species have been shown to be particularly stimulated by charate (Keeley 1987).

The component of the charred wood that stimulates germination of species is not understood completely; however, studies indicate plant species may differ in the barriers that must be overcome to provoke germination (Keeley and Fotheringham 1998). Wood ash had no stimulatory effect on seed germination (Sweeney 1956); however, it appears that the degree of charring is not critical. For example, chamise stems charred only on the outside (and ground to a powder) were as effective as thoroughly charred stems in stimulating germination (Keeley et al. 1985). The amount of powered, charred wood required to stimulate germination also does not appear to be critical (Keeley et al. 1985). It has also been shown that germination can be induced by an aqueous extract of charred 
wood but not by unburned wood or activated charcoal (Keeley and Nitzberg 1984, Keeley and Pizzaono 1986).

\section{Smoke Treatment}

Smoke has been shown to be an important chemical stimulant for seed germination in many species. It was first demonstrated using seeds from a South African fynbos shrub (de Lange and Boucher 1990), and later in many other fynbos species (Brown 1993), a savannah grass (Baxter and van Staden 1994), a Great Basin annual (Baldwin et al. 1994), and a large number of Australian heath shrubs (Dixon et al. 1995, Roche et al. 1997). Smoke-stimulated seed germination has also been reported for many California chaparral species including chamise (Keeley et al. 2005).

Although the mechanism of smoke-triggered germination is not known, studies indicate that species with smoke-induced seed germination may differ in the barriers that must be overcome to induce germination. Hypothesized mechanisms that stimulate seed germination in seeds treated by smoke and charate include: (1) increased solute permeability of the subdermal cuticle may enhance the uptake of ions or gases that induce germination; (2) increased solute permeability of the subdermal cuticle may result in the leaching out of internal inhibitors; (3) nitrates in smoke may trigger germination; (4) acids in smoke may lead to internal acidification; and (5) induction of enzymes or growth regulators by chemicals in smoke (Keeley and Fotheringham 1998). While some studies show that one of the inorganic gases in smoke, nitrogen dioxide, could trigger complete germination in some species (Keeley and Fotheringham 1998), other studies performed by organic chemists have reported that an organic decomposition product found in smoke 
(butenolide 3-methyl-2H-furo[2,3-c]pyran-2-one) can also trigger germination (Flematti et al. 2004).

Smoke derived from plants outside of fire prone ecosystems have been found to be as effective as smoke from chaparral communities. For example, Keeley and Fotheringham (1998) found that smoke from pine sawdust stimulates seed germination equally to smoke from chamise wood. Liquid smoke, either in the form of commercial food flavoring or smoke treated water, has also been found to be effective in triggering germination of many species (Jager et al. 1996, Keeley et al. 2005). Spraying soil with liquid smoke has also shown to induced emergence of some species (Burne et al. 2003).

The duration of smoke exposure required to induce germination varies from species to species and too much exposure may decrease germination. For example, a 15-minute exposure may be lethal to one species but optimum for another (Keeley and Fotheringham 1998). Previous research has shown a significant increase in chamise's seed germination when exposed to a commercial liquid smoke dilution (Keeley et al. 2005); however, it's optimum and lethal exposure times to natural smoke has not been examined. 


\section{CHAPTER II}

\section{METHODS AND MATERIALS}

\section{PROJECT SITE AND TEST PLOT DESIGN}

Test plots were established on a finished slope in Rocky Canyon Quarry to study seed germination of chamise seeds under field conditions. The plots were located on a southeast facing hillside west of the Rocky Canyon Creek and north of the CalPortland office trailer (Figure 8).

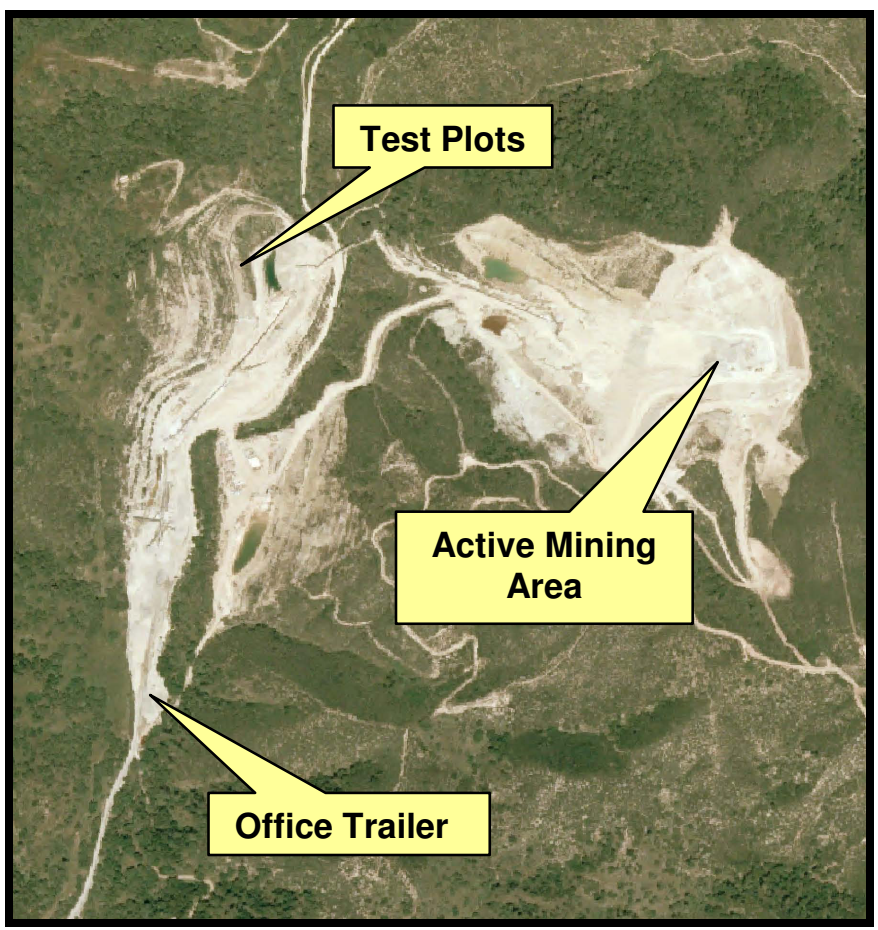

Figure 8. Location of the Experimental Plots within the Rocky Canyon Granite Quarry 
To reduce the effects of rainfall sheet flow, I decided to place the test plots on one of the level benches between two finished slopes. To determine the best location, I examined five benches that had been constructed and covered with topsoil. Each potential location was examined using the following criteria: (1) sufficient size to fit all test plots, (2) adequate levelness to reduce the effect of rain sheet flow, and (3) proper topsoil particle size to avoid numerous large rocky areas. The location selected for the study site is on the northern end of the second bench (starting from the bottom). Prior attempts to revegetate this bench resulted in minimal success and the vegetation cover on the surrounding hillsides was sparse and dominated by deerweed, sticky monkey flower, yellow star-thistle, foxtail fescue and smooth cat's ear.

The test plots were created in 2002 using 17-inch x 17-inch x 2-inch $(43.8 \mathrm{~cm} \times 43.8$ $\mathrm{cm} \times 5 \mathrm{~cm}$ ) black plastic nursery flats. The bottoms of the flats were removed except for a 2-inch $(5 \mathrm{~cm})$ border that was used to secure the flats to the compacted topsoil of the bench. The plots were placed in a level spot and were cleared of vegetation and rocks that were 1 inch $(2.5 \mathrm{~cm})$ or larger. The flat was placed directly on the surface of the topsoil and a 2-inch $(5 \mathrm{~cm})$ galvanized steel staple was used to secure each corner of the flat in place.

To ensure the test plots contained soil that was identical to that on the finished slopes, I collected topsoil from the slope directly above the experimental area. All vegetation was cleared from the surface and a pick hammer was used to loosen and collect the topsoil. The large rocks were removed by sifting the topsoil through a 3/8-inch $(1 \mathrm{~cm})$ screen before putting it in the test plot flats. The sifted topsoil was leveled in each plastic nursery flat leaving a 1 inch $(2.5 \mathrm{~cm})$ plastic border around each test plot above 
the soil (Figure 9). This border helped contain seeds and treatment materials so they would not be washed away by sheet flow during a rain storm. Seed treatments used in the test plots were assigned randomly.

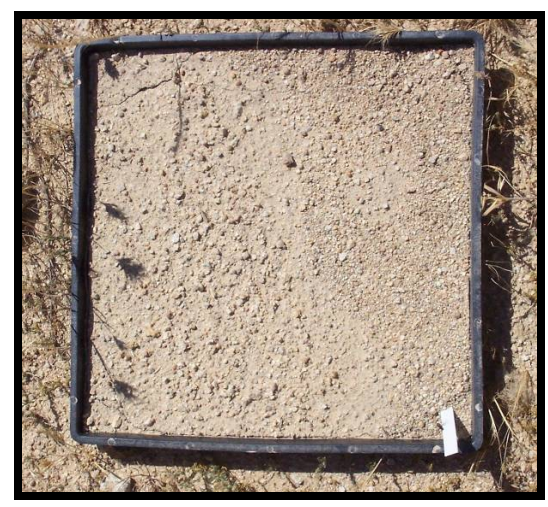

Figure 9. Experimental Test Plot

After collecting data for the 2002-2003 season, I had to remove the study plots to allow maintenance vehicles access to the bench for the summer. Soil from the plots, along with any ungerminated seeds, was cast downhill to the finished slope below. In Fall 2003, following the maintenance activities, the test plots were reinstalled using the same procedures used in 2002 (Figure 10).

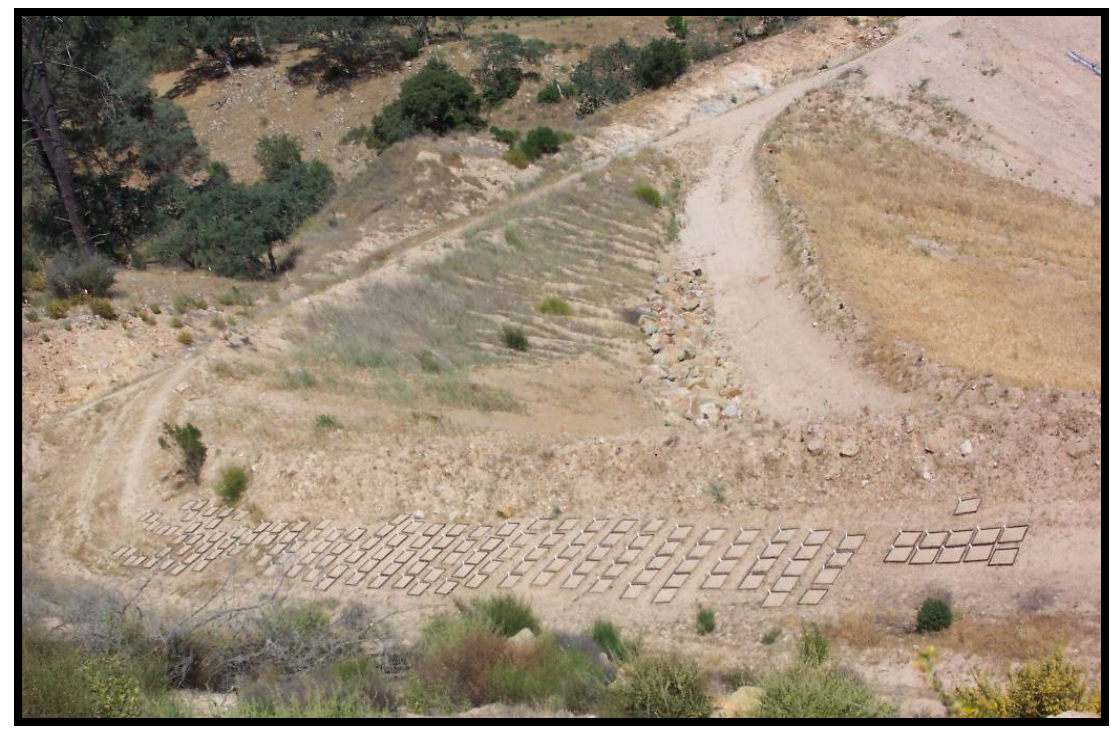

Figure 10. Overview of the 2003-2004 Experimental Test Plots. 


\section{SEED COLLECTING}

Chamise seeds were gathered from undisturbed hillsides of Rocky Canyon between July 30 and August 5, 2002, for use in the test plots during the first year (2002-2003) of my study. During this time period, the seeds had not fallen from the parent shrub but were easily removed by a light touch. The seeds were cleaned by sifting them through a fine screen. I also purchased chamise seeds from S\&S Seeds (Carpentaria, California) to make sure I had enough seeds to conduct all the experiments used in my study. The two seed supplies were combined and thoroughly mixed together to make sure a uniform application of seeds was used.

Although the seed crop for chamise is abundant, seed viability is quite low, largely due to the high percentage of empty achenes (one seeded fruits), which are not readily distinguishable from good achenes (Keeley 1987). To insure that there were sufficient amounts of viable achenes, approximately 2000 seeds were desired for each test plot. Chamise achenes are tiny and counting out 2000 seeds for each plot would be very difficult and time consuming. Therefore, I counted and weighed three sets of 1000 seeds and found they had an average weight of 1.36 grams $(1.5,1.2$, and 1.3). Based on these data, I decided to seed each study plot with 3.0 grams of chamise seeds (approximately 2205 seeds). Seeds were measured out using an electronic scale and then stored in paper envelopes in a cool, dry area.

All chamise seeds used in second year (2003-2004) of my research were gathered from the undisturbed hillsides of Rocky Canyon between July 15 and August 25, 2003. These seeds were cleaned and stored in one large paper bag. To improve the continuity of the treatment procedures between the test plots and to simplify the treatment procedures, 
sets of seeds were not weighed out until after the pre-field treatments were completed. To adjust for any weight difference that occurred to the seeds during the treatment procedures, sample sets of 3.0 grams of seeds also received the treatment procedures and then were weighted. Sets of seeds used for the experimental test plots were weighted at the same weight as the sample set that received the identical treatments.

\section{SEED TREATMENTS}

Four dormancy-breaking treatments were tested and compared: heat, charate, smoke and sulfuric acid soak. Some seeds were given just one treatment while others were given various combinations up to four different treatments. This allowed me to examine the effects of a single treatment on breaking the dormancy of chamise seeds and also to determine if a combination of treatments may act synergistically to stimulate germination. The various treatments and combination of treatments are shown in Table 1 . Effects of charate were examined by two techniques: charate soak and charate field, and effects of smoke were examined by three techniques: liquid smoke soak, liquid smoke field and natural chamise smoke. This resulted in a total of seven different dormancy breaking treatments. The methods used to perform these techniques are explained later in this report.

In 2002-2003 when a combination of treatments was given to chamise seeds, the treatments were given in the precise order shown below.
1) Heat
2) Liquid Smoke Soak or Chamise Smoke
3) Charate Soak
4) Sulfuric Acid Soak
5) Charate Field
6) Liquid Smoke Field 
Table 1. Seed Treatments

\begin{tabular}{|c|c|c|c|c|c|c|c|}
\hline & Heat & $\begin{array}{c}\text { Charate } \\
\text { Soak }\end{array}$ & $\begin{array}{c}\text { Charate } \\
\text { Field }\end{array}$ & $\begin{array}{c}\text { Liquid } \\
\text { Smoke } \\
\text { Soak }\end{array}$ & $\begin{array}{l}\text { Liquid } \\
\text { Smoke } \\
\text { Field }\end{array}$ & $\begin{array}{c}\text { Chamise } \\
\text { Smoke }\end{array}$ & $\begin{array}{c}\text { Sulfuric } \\
\text { Acid Soak }\end{array}$ \\
\hline 1 & \multicolumn{7}{|c|}{ No seeds- No treatment } \\
\hline 2 & \multicolumn{7}{|c|}{ Seeds -No treatment } \\
\hline 3 & $\mathrm{X}$ & & & & & & \\
\hline 4 & & $\mathrm{X}$ & & & & & \\
\hline 5 & & & $\mathrm{X}$ & & & & \\
\hline 6 & & & & $\mathrm{X}$ & & & \\
\hline 7 & & & & & $\mathrm{X}$ & & \\
\hline 8 & & & & & & $\mathrm{X}$ & \\
\hline 9 & & & & & & & $\mathrm{X}$ \\
\hline 10 & $\mathrm{X}$ & $\mathrm{X}$ & & & & & \\
\hline 11 & $\mathrm{X}$ & & $\mathrm{X}$ & & & & \\
\hline 12 & $\mathrm{X}$ & & & $\mathrm{X}$ & & & \\
\hline 13 & $\mathrm{X}$ & & & & $\mathrm{X}$ & & \\
\hline 14 & $\mathrm{X}$ & & & & & $\mathrm{X}$ & \\
\hline 15 & $\mathrm{X}$ & & & & & & $\mathrm{X}$ \\
\hline 16 & & $\mathrm{X}$ & & $\mathrm{X}$ & & & \\
\hline 17 & & & $\mathrm{X}$ & $\mathrm{X}$ & & & \\
\hline 18 & & & & $\mathrm{X}$ & & & $\mathrm{X}$ \\
\hline 19 & & $\mathrm{X}$ & & & $\mathrm{X}$ & & \\
\hline 20 & & & $\mathrm{X}$ & & $\mathrm{X}$ & & \\
\hline 21 & & & & & $\mathrm{X}$ & & $\mathrm{X}$ \\
\hline 22 & & $\mathrm{X}$ & & & & $\mathrm{X}$ & \\
\hline 23 & & & $\mathrm{X}$ & & & $\mathrm{X}$ & \\
\hline 24 & & & & & & $\mathrm{X}$ & $\mathrm{X}$ \\
\hline 25 & & $\mathrm{X}$ & & & & & $\mathrm{X}$ \\
\hline 26 & & & $\mathrm{X}$ & & & & $\mathrm{X}$ \\
\hline 27 & $\mathrm{X}$ & $\mathrm{X}$ & & $\mathrm{X}$ & & & \\
\hline 28 & $\mathrm{X}$ & $\mathrm{X}$ & & & $\mathrm{X}$ & & \\
\hline 29 & $\mathrm{X}$ & $\mathrm{X}$ & & & & $\mathrm{X}$ & \\
\hline 30 & $\mathrm{X}$ & & $\mathrm{X}$ & $\mathrm{X}$ & & & \\
\hline 31 & $X$ & & $X$ & & $X$ & & \\
\hline 32 & $\mathrm{X}$ & & $\mathrm{X}$ & & & $\mathrm{X}$ & \\
\hline 33 & & $X$ & & $X$ & & & $X$ \\
\hline 34 & & $\mathrm{X}$ & & & $\mathrm{X}$ & & $\mathrm{X}$ \\
\hline 35 & & $\mathrm{X}$ & & & & $\mathrm{X}$ & $\mathrm{X}$ \\
\hline 36 & & & $\mathrm{X}$ & X & & & $\mathrm{X}$ \\
\hline 37 & & & $\mathrm{X}$ & & $\mathrm{X}$ & & $\mathrm{X}$ \\
\hline 38 & & & X & & & $\mathrm{X}$ & $\mathrm{X}$ \\
\hline 39 & $X$ & $X$ & & & & & $X$ \\
\hline 40 & $\mathrm{X}$ & & $\mathrm{X}$ & & & & $\mathrm{X}$ \\
\hline 41 & $\mathrm{X}$ & & & $\mathrm{X}$ & & & $\mathrm{X}$ \\
\hline 42 & $\mathrm{X}$ & & & & $\mathrm{X}$ & & $\mathrm{X}$ \\
\hline 43 & $\mathrm{X}$ & & & & & $\mathrm{X}$ & $\mathrm{X}$ \\
\hline 44 & $\mathrm{X}$ & $\mathrm{X}$ & & $\mathrm{X}$ & & & $\mathrm{X}$ \\
\hline 45 & $\mathrm{X}$ & $\mathrm{X}$ & & & $\mathrm{X}$ & & $\mathrm{X}$ \\
\hline 46 & $\mathrm{X}$ & $\mathrm{X}$ & & & & $\mathrm{X}$ & $\mathrm{X}$ \\
\hline 47 & $\mathrm{X}$ & & $\mathrm{X}$ & $\mathrm{X}$ & & & $\mathrm{X}$ \\
\hline 48 & $\mathrm{X}$ & & $\mathrm{X}$ & & $\mathrm{X}$ & & $\mathrm{X}$ \\
\hline 49 & $\mathrm{X}$ & & $\mathrm{X}$ & & & $\mathrm{X}$ & $\mathrm{X}$ \\
\hline
\end{tabular}


Since the sulfuric acid soak is used as a scarification technique to penetrate a hardened seed coat, in 2003-2004 it was moved to the second treatment to better replicate the course of action a seed would experience in a natural fire. By performing the sulfuric acid soak prior to the chemical treatments, it also alleviates the possibility of washing away the chemical properties of the other treatments. Seeds receiving more than one treatment in the second year received them in the following order.
1) Heat
2) Sulfuric Acid Soak
3) Liquid Smoke Soak or Chamise Smoke
4) Charate Soak
5) Charate Field
6) Liquid Smoke Field

In addition to the treated seeds, two controls were included in the study: (1) one set of experimental plots were left unaltered (no chamise seeds or dormancy breaking treatment) to examine the natural seed bank, and (2) one set of experimental plots were seeded with chamise that had no treatment to examine the germination rate of chamise seeds without a dormancy breaking trigger. The two controls along with the single and multiple treatments resulted in 49 different seed treatments (Table 1), each of which had three replications resulting in 147 test plots.

\section{Heat Treatment Methods}

In 2002-2003 for each group that received heat as a treatment, three grams of dry chamise seeds were placed in a 2-inch $(5 \mathrm{~cm})$ diameter paper baking cup and then placed in a $180^{\circ} \mathrm{F}$ convectional oven for fifteen minutes. Following heating groups of seeds that had completed their treatment and groups of seeds that required only additional field procedures were returned to their storage envelopes and kept in a cool dry area until used. 
In the second year (2003-2004), approximately $3 \mathrm{lbs}(1.36 \mathrm{~kg})$ of chamise seed was spread in a single layer on the baking pan and placed in a $180^{\circ} \mathrm{F}$ oven for fifteen minutes. Following heating groups of seeds were weighed out into 3 gram sets for those plots that had completed their treatment and for those that required only additional field procedures and stored in envelopes placed in a cool, dry area.

\section{Sulfuric Acid Soak Treatment Methods}

In 2002-2003, for each group that received sulfuric acid soak as a treatment, three grams of chamise seeds were placed in a wire strainer and immersed in container with approximately $100 \mathrm{ml}$ of $10 \%$ sulfuric acid solution at room temperature for 15 minutes. The seeds were gently stirred through out the immersion period to insure thorough interaction with the sulfuric acid solution. Following treatment, the seeds were removed from the acid solution, and promptly and thoroughly washed in cool running water for 5 minutes. Following rinsing, all seeds were allowed to air dry and then stored in envelopes placed in a cool, dry area.

In the second year (2003-2004), two acid resistant glass containers were each filled with approximately $300 \mathrm{ml}$ of a room temperature $10 \%$ sulfuric acid solution. $1.5 \mathrm{lbs}$ $(0.68 \mathrm{~kg})$ of chamise seeds were immersed in each container. One container had seeds that previously received a heat treatment and one had seeds that did not. The seeds were gently stirred through out the 15 minute immersion period to insure thorough interaction with the sulfuric acid solution. Following treatment the seeds were removed from the acid solution and washed promptly and thoroughly in cool running water for 5 minutes. Following the rinsing, all seeds were allowed to air dry. Groups of seeds were weighted 
out for those plots that had completed their treatment and those that required only additional field procedures.

\section{Smoke Treatment Methods}

Effects of smoke were examined by three techniques: liquid smoke soak, liquid smoke field, and natural chamise smoke. Each is explained separately below.

\section{Liquid Smoke Soak}

In 2002-2003, the sets of seeds to receive a liquid smoke soak treatment were soaked in a solution made from a Kirstenbosch Instant Smoke Plus Seed Primer Disk, which is a piece of absorbent paper that is impregnated with fynbos-smoke-saturated water. The disk arrives from the factory dried and sealed in a polythene packet. To activate the smoke saturated solution for each group of seeds, $50 \mathrm{ml}$ of distilled water was added to the primer disk in an 8 ounce plastic container. The three grams of chamise seeds were then "smoke-primed" by soaking in the smoke-water solution for 24 hours. Each group of seeds was regularly stirred during the immersion period to insure complete seed contact with the liquid smoke solution. After 24 hours the liquid smoke solution was drained, and the seeds were allowed to completely air dry. Groups of seeds that had completed their treatment and groups of seeds that required only additional field procedures were returned to their storage envelopes and placed in a cool dry area.

In 2003-2004, four glass containers were each filled with $500 \mathrm{ml}$ of distilled water and 10 Kirstenbosch Instant Smoke Plus Seed Primer Disks to activate the smoke saturated solution. One container received approximately $0.33 \mathrm{lbs}(0.15 \mathrm{~kg})$ of chamise seeds that had not received any other treatment, one container received approximately 
$0.33 \mathrm{lbs}(0.15 \mathrm{~kg})$ of chamise seeds that had received a heat treatment, one container received approximately $0.33 \mathrm{lbs}(0.15 \mathrm{~kg})$ of chamise seeds that had received a sulfuric acid soak treatment, and one container received approximately $0.33 \mathrm{lbs}(0.15 \mathrm{~kg})$ of chamise seeds that had received both the heat and the sulfuric acid soak treatment. Each group of seeds was regularly stirred during the immersion period to insure complete contact with the liquid smoke solution. After 24 hours the liquid smoke solution was drained and the seeds were allowed to completely air dry. Groups of seeds were weighted out for those plots that had completed their treatment and those that required additional field procedures and stored in envelopes placed in a cool, dry area.

\section{Chamise Smoke}

In 2002-2003, smoke was produced by burning green mature chamise branches collected from the undisturbed hillsides of Rocky Canyon. The branches were run through a chipper resulting in small chips of wood and sticks. Approximately one cup of the chips was placed in a small metal pan and set on the heating element of a meat smoker. The smoker consisted of a 12 inch x 12 inch x 24 inch $(30.5 \mathrm{~cm}$ x $30.5 \mathrm{~cm}$ x 61 $\mathrm{cm}$ ) aluminum closed box with an electric heating coil located at the bottom. To avoid any effect of heat on the chamise seeds that would result from the heating element inside the smoker, several large holes were drilled in the top of the smoker and a five gallon plastic bucket was placed upside down covering the holes (Figures 11 and 12). For each smoking treatment, fresh chips were added to the pan on the heating element. Smoke produced in the smoker escaped through the drilled holes and was caught in the five gallon plastic bucket. The bucket was allowed to fill and once smoke was observed overflowing the bucket capacity, it was quickly lifted just high enough to add the chamise 
seeds. For each group receiving the natural chamise smoke the three grams of chamise seeds were placed in 2-inch $(5 \mathrm{~cm})$ diameter paper baking cups. The baking cups with the seeds were placed inside the smoke filled plastic bucket on a wire rack approximately 3inches $(7.6 \mathrm{~cm})$ above the lid of the smoker for 10 minutes. Smoke was continually produced through out the 10 minute treatment period to insure a thorough smoke treatment. Following treatment groups of seeds that had completed their treatment and those that required additional field procedures were returned to their storage envelopes and placed in a cool, dry area.

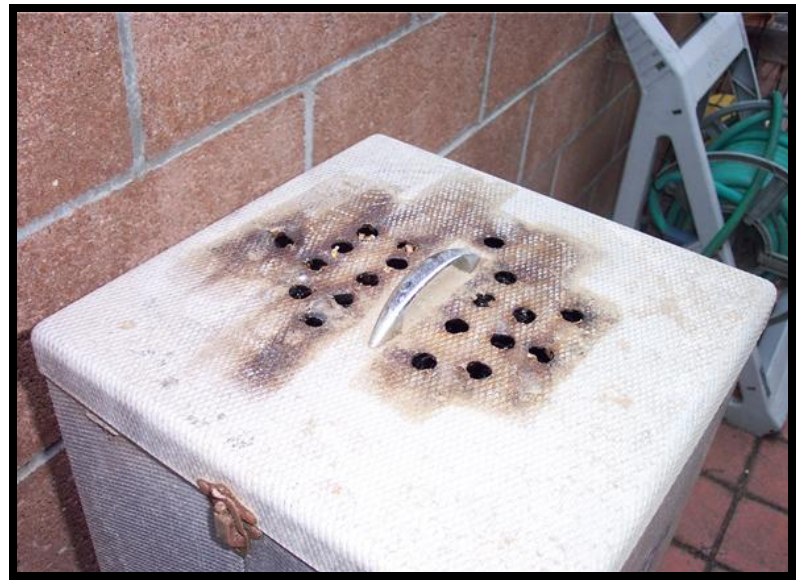

Figure 11. Holes Cut into the Top of the Smoker.

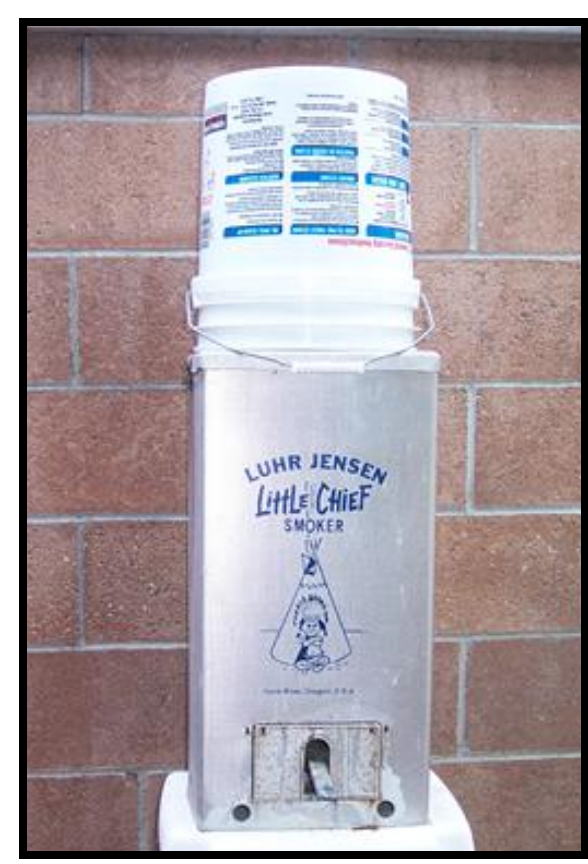

Figure 12. Smoker Set Up.

In the second year (2003-2004), smoke was produced in the smoker and captured in the five gallon bucket in the same manner as the 2002-2003 trial. However, four 7.5inches $(19 \mathrm{~cm})$ diameter paper coffee filters were used instead of paper cups to hold the chamise seeds. One filter received approximately $0.33 \mathrm{lbs}(0.15 \mathrm{~kg})$ of chamise seeds that 
had not received any other treatment, one filter received approximately $0.33 \mathrm{lbs}(0.15 \mathrm{~kg})$

of chamise seed that had received a heat treatment, one filter received approximately 0.33 lbs $(0.15 \mathrm{~kg})$ of chamise seed that had received an sulfuric acid soak treatment, and one filter received approximately $0.33 \mathrm{lbs}(0.15 \mathrm{~kg})$ of chamise seed that had received both the heat and the sulfuric acid soak treatment. The filters and seeds were placed inside the smoke filled bucket on a wire rack approximately 3-inches $(7.6 \mathrm{~cm})$ above the lid of the smoker for 10 minutes. Smoke was continually produced through out the treatment period. Groups of seeds were weighted out for those plots that had completed their treatment and those that required only additional field procedures and stored in envelopes placed in a cool, dry area.

\section{Liquid Smoke Field}

To activate the liquid smoke solution one Kirstenbosch Instant Smoke Plus Seed Primer Disk was added to $100 \mathrm{ml}$ of distilled water. After the plots receiving a liquid smoke treated were uniformly seeded with their three grams of chamise seeds, the entire $100 \mathrm{ml}$ of liquid smoke solution was sprayed over the test plot using a hand-held plastic spray bottle.

\section{Charate Treatment Methods}

Charate was made from mature chamise branches that were collected from the undisturbed hillsides of Rocky Canyon. The branches were cut to fit into a 30-gallon metal trashcan and ignited. The material easily ignited using small branches and twigs; no chemical accelerant was necessary. The branches were allowed to burn until the first sign of ash appeared. The trashcan lid was then put in place until the fire was completely 
smothered. Once the material was cool, all stems and branches were inspected, and those that were not completely blackened throughout were burned again with the next batch of branches. The branches that were completely blackened were removed and ground to a powder using a commercial blender. The powder was sifted through a $3 \mathrm{~mm}$ screen to produce the fine charate used in my research. Effects of charate were examined by two techniques, charate soak and charate field, which are discussed below.

\section{Charate Soak}

In the first year (2002-2003), 80 grams of charate powder was mixed with 4 liters of distilled water to make charate solution. Each group of chamise seeds receiving the charate soak procedure was loosely wrapped in a fine mesh tied with a rubber band and immersed in the charate solution for 24 hours. The solution was regularly stirred during the immersion period to insure that the seeds made complete contact with the charate. After 24 hours, the seeds were removed and allowed to completely air dry. Groups of seeds that had completed their treatment and groups of seeds that required only additional field procedures were returned to their storage envelopes and placed in a cool, dry area.

In 2003-2004, the charate solution was prepared in the same manner as 2002-2003. Twelve groups of seeds each with $0.25 \mathrm{lbs}(0.11 \mathrm{~kg})$ of chamise seeds each were loosely wrapped in fine mesh, tied with a rubber band and immersed in the solution for 24 hours. The groups consisted of chamise seeds that had not received any other treatment and seeds that had received one or more treatment of heat, scarification, liquid smoke soak, and chamise smoke. The solution was regularly stirred during the immersion period to insure complete seed contact with the charate. After 24 hours in the charate solution, the seeds were removed from the mesh and allowed to completely air dry. Groups of seeds 
were weighted out for those plots that had completed their treatment and those that required only additional field procedures, and stored in envelopes placed in a cool, dry area.

\section{Charate Field}

In 2002-2003, 80 grams of the powdered charate was spread over the test plots receiving the charate field treatment. To help prevent the charate from washing away during the rainy season, it was manually mixed in the top 0.5 inch $(1.3 \mathrm{~cm})$ of topsoil with a small hand held rake.

In $2003-2004$, the top 0.5 inch $(1.3 \mathrm{~cm})$ of soil was removed from the plot and mixed in a bucket with 80 grams of powered charate. This assured a more uniform distribution of the charate powder through out the soil. Half of the soil-charate mixture was placed in the plot and then the three grams of chamise seeds were sprinkled uniformly over the test plot. The seeds were then covered with the remaining soil-charate mixture.

\section{PLANTING PROCEDURES}

In 2003-2004, seeds were planted in the test plots between October 26, 2002 and November 5, 2002 prior to the first significant rain. Each test plot was uniformly seeded with three grams of chamise seeds and mixed into the top 0.5 inches $(1.3 \mathrm{~cm})$ of the topsoil. In 2003-2004, seeds were planted in the test plots between October 15, 2003 and October 30, 2003 prior to the first significant rain of the season. For each test plot, the three grams of chamise seeds were uniformly spread over the test plot and covered with an additional 0.25 inch $(0.6 \mathrm{~cm})$ layer of top soil to achieve a more uniform burial depth. 


\section{SAMPLING AND MONITORING}

Once the plots had been seeded, no additional treatments were used and none of the plots was irrigated. Plots were monitored weekly to determine chamise seedling emergence. During weekly monitoring, the plots were also weeded to prevent competition. In the first year, the first chamise seedling was observed on March 6, 2003 whereas in the second year they were observed on February 26, 2004. Figure 13 shows newly emerged chamise cotyledons in an experimental plot.

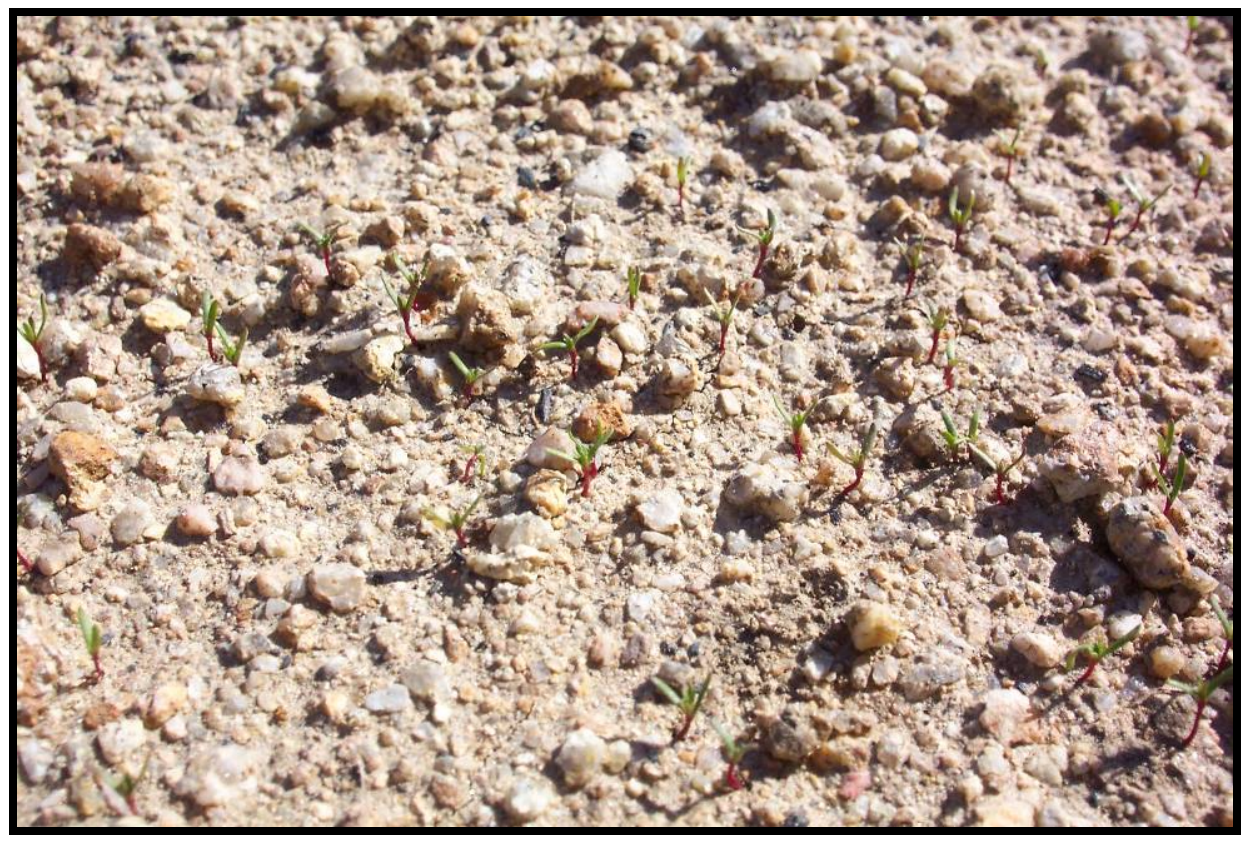

Figure 13. Chamise Cotyledons in a 2003- 2004 Experimental Plot.

Chamise seedlings were counted in each plot and then removed to prevent repeat countings and competition. All plots were examined three times during the growing season to avoid any missed or late emerging seedlings. 


\section{CHAPTER III}

\section{ANALYSIS OF DATA}

All statistics were performed with the statistical package MINITAB 15 for windows by Minitab, Inc. The Minitab output for all statistical analyses included in this thesis is presented in Appendix B. Data from the 2002-2003 trial and the 2003-2004 trial were analyzed separately following identical methods. The control plots used to examine the existing condition of the test area, which had no chamise seeds added to them, were included only to verify that chamise seedlings do not occur naturally in this habitat. Since the data gather from these plots (no seedlings observed in any plot) were not involved in showing if a treatment increased the germination rate of chamise seeds, they were not included in the data analysis. Prior to all analyses, the data were square root transformed to improve homogeneity of variance and normality.

To determine if there was a significant difference among the treatments in breaking dormancy in chamise seeds, a one-way Analysis of Variance (ANOVA) test was performed using an alpha level of 0.05 . To more precisely analyze differences among treatment means, Hsu's multiple comparison with the best (MCB) method was used to identify treatments that are the best at increasing seed germination, and those that are significantly different from the best. An alpha level of 0.05 was used. 
An exploratory analysis was performed by doing a second one-way ANOVA test and Hsu's MCB method on the data from the treatments that were found to be the best and those that were insignificantly different from the best. The alpha level was 0.05 for both procedures. Due to the increase in a Type I error, the statistical significance of these results is only suggestive and used for exploratory purposes in an attempt to reduce the number of treatment procedures down to the best select few.

Differences in the mean number of seeds that germinated in the different treatments were analyzed statistically using the general linear model analysis of variance and Tukey's HSD test for main effects (heat, sulfuric acid soak, charate soak, charate field, liquid smoke soak, liquid smoke field and chamise smoke) and two-way interactions (heat $\mathrm{x}$ sulfuric acid soak, heat x charate soak, etc.). An alpha level of 0.05 was used. Graphical representations of these analyses were created utilizing interval plots. To ease the interpretation of the graphs, the interval plots were generated using raw data for the number of seeds germinated rather than data that had been square root transformed. Additionally, to create a true representation of the treatments effects on chamise seed germination, interval plots were made without data from similar treatments in which they did not interact. When performing the treatments, seeds that received either a charate treatment or a smoke treatment received only one from each group. For example, if seeds received a liquid smoke field treatment, they never received a liquid smoke soak or chamise smoke treatment. By creating an interval plot with all the data, the seeds germinated by the later two smoke treatments skewed graph to the "No Liquid Smoke Field Treatment" side. This skewing of the graph creates an effect that liquid smoke field has a negative affect on the germination of the chamise seeds; wherein as proper analysis 
of the data shows it has either no significant affect or a slight positive effect. For comparison purposes, main effects and two-way interaction interval plots were created for the charate and smoke treatments using all the data and are included in Appendix C. 


\section{CHAPTER IV}

\section{RESULTS}

\section{GERMINATION RESULTS}

Appendix A tables A1 and A2 provide the total number of chamise seedlings observed in each of the plots during the two growing seasons. Figures 14 and 15 show the mean number of germinated seeds observed in the plots for each treatment during 20022003 and 2003-2004 respectively.

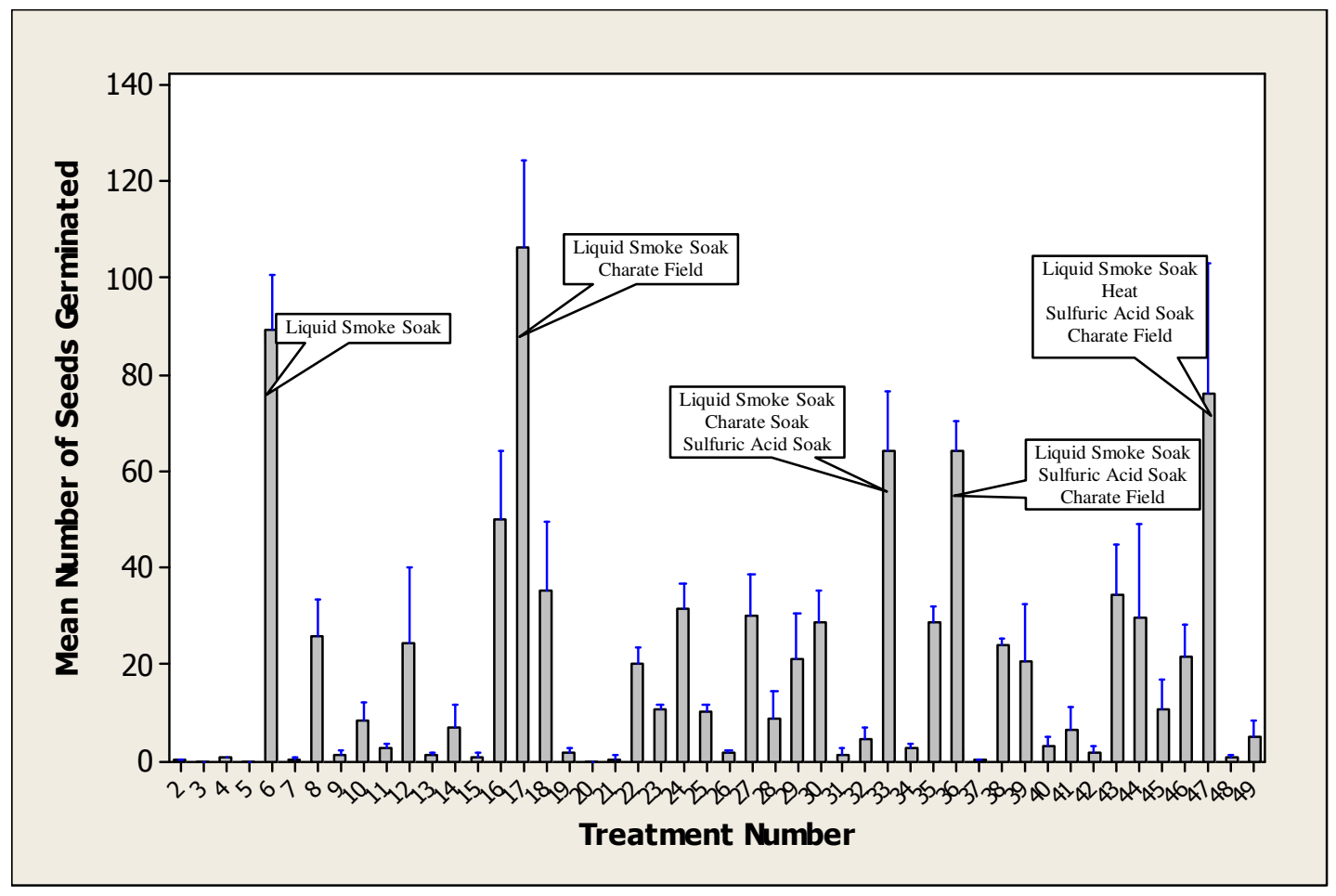

Figure 14. Number of Seeds Germinated in the 2002-2003 Experimental Season by Treatment. Error bars represent the standard error of the mean. 


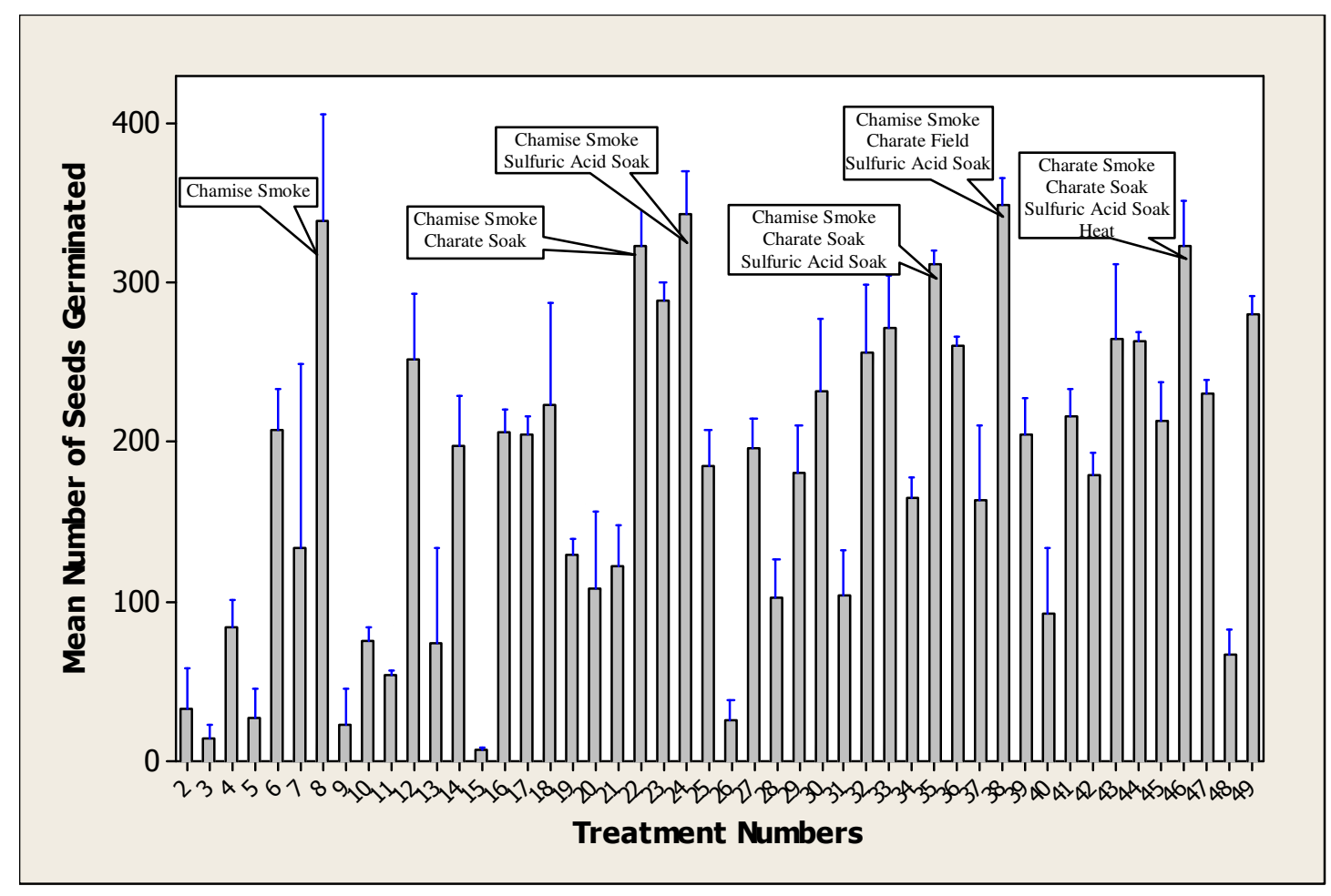

Figure 15. Number of Seeds Germinated in the 2003-2004 Experimental Season by Treatment. Error bars represent the standard error of the mean.

Data show that chamise seed germination was higher in 2003-2004 compared to 2002-2003. Although the reasons for these differences are not known, several potential explanations are plausible.

Variations in the weather conditions between the two years could have had an influence on the germination rate. From the time the seeds were developing on the parent plant, differences in the climatic conditions could have affected the viability of the seeds. Additionally, once the treated seeds were added to the experimental plots differences in precipitation and temperature may have affected the germination rate. Differences in temperature and precipitation rate between the two seasons can be seen in Chapter 1 Figures 2-5.

Another possible explanation is the change in planting procedures between the 2002-2003 and 2003-2004 years. In the second year, 2003-2004, the seeds were covered 
by an approximately 0.25 inch $(0.6 \mathrm{~cm})$ layer of topsoil while during the first year, they were sprinkled over the plot and then lightly mixed into the topsoil with a hand held rake. This light mixing resulted in a number of the chamise seeds remaining on the surface of the topsoil. Although several germinated seeds were observed on the surface of the topsoil, it is likely this planting procedure did not provide as good germination conditions as the seeds that were buried.

While the differences in seed germination rates between the two years might be a result of different weather conditions or planting procedures, the differences in seed germination within each year is due to the differences in treatments as the climatic conditions and planting procedures were the same for all plots.

\section{STATISTICAL RESULTS}

A one-way ANOVA performed on the 2002-2003 data showed there are significant differences among the treatments in breaking chamise seed dormancy $(F=11.16, d f=47$, $\mathrm{P}=0.000$ ). Hsu's MCB method showed that six of the forty-eight treatments were the best or insignificantly different from the best. These six treatments were all treated by liquid smoke soak by itself or in combination with one or more other treatments (Table 2). These data provide evidence that the liquid smoke soak treatment is an effective treatment for breaking dormancy of chamise seeds.

For the 2002-2003 data, a second one-way ANOVA performed on the six treatments found to be the best or insignificantly different from the best, showed no significant difference between the treatments at breaking dormancy in chamise seeds $(F=1.18, d f=4$, $\mathrm{P}=0.377)$. 
Table 2. 2002-2003 Treatments Found to be the Best and Insignificantly Different from the Best.

\begin{tabular}{|c|c|c|c|c|c|c|c|}
\hline $\begin{array}{c}\text { Treatment } \\
\#\end{array}$ & Heat & SAS $^{*}$ & $\mathrm{CS}^{*}$ & $\mathrm{CF}^{*}$ & $\mathrm{ChS}^{*}$ & LSS $^{*}$ & LSF* $^{*}$ \\
\hline 6 & & & & & & $\mathrm{X}$ & \\
\hline 16 & & & $\mathrm{X}$ & & & $\mathrm{X}$ & \\
\hline 17 & & & & $\mathrm{X}$ & & $\mathrm{X}$ & \\
\hline 33 & & $\mathrm{X}$ & $\mathrm{X}$ & & & $\mathrm{X}$ & \\
\hline 36 & & $\mathrm{X}$ & & $\mathrm{X}$ & & $\mathrm{X}$ & \\
\hline 47 & $\mathrm{X}$ & $\mathrm{X}$ & & $\mathrm{X}$ & & $\mathrm{X}$ & \\
\hline
\end{tabular}

In 2003-2004, a one-way ANOVA performed on all the data also showed there was a significant difference between the treatment sets at breaking dormancy in chamise seeds $(\mathrm{F}=9.68, \mathrm{df}=47, \mathrm{P}=0.000)$. Hsu's MCB method showed that twenty-nine of the fortyeight treatments were found to be the best or insignificantly different from the best (Table 3). Although there is not a single treatment that stands out as a common factor that significantly increased germination, it is notable that all of the procedures that included liquid smoke soak or chamise smoke as a dormancy breaking technique (twenty-four treatments) were included in this best or insignificantly different from the best group.

A second one-way ANOVA performed on the 2003-2004 data with the twenty-nine treatments found to be the best or insignificantly different from the best, showed that there was a significant difference between the treatments at breaking dormancy in chamise seeds $(\mathrm{F}=10.51, \mathrm{df}=30, \mathrm{P}=0.000)$. A second Hsu's MCB method showed that of the twenty-nine treatments, eighteen were found to be the best or insignificantly different from the best (Table 4). Once again there is not a single treatment that stands out as the

\footnotetext{
* SAS - Sulfuric acid soak ChS - Chamise smoke

CS - Charate soak LSS - Liquid smoke soak

$\mathrm{CF}$ - Charate field

LSF - Liquid smoke field
} 
common factor that produced the significantly higher germination rates; however liquid smoke soak or chamise smoke was used in sixteen of the eighteen treatments.

Table 3. 2003-2004 Treatments Found to be the Best and Insignificantly Different from the Best.

\begin{tabular}{|c|c|c|c|c|c|c|c|}
\hline $\begin{array}{c}\text { Treatment } \\
\#\end{array}$ & Heat & SAS & CS* & $\mathrm{CF}^{*}$ & $\mathrm{ChS}{ }^{*}$ & LSS* & LSF* \\
\hline 6 & & & & & & $\mathrm{X}$ & \\
\hline 8 & & & & & $\mathrm{X}$ & & \\
\hline 12 & $\mathrm{X}$ & & & & & $\mathrm{X}$ & \\
\hline 14 & $\mathrm{X}$ & & & & $\mathrm{X}$ & & \\
\hline 16 & & & $\mathrm{X}$ & & & $\mathrm{X}$ & \\
\hline 17 & & & & $\mathrm{X}$ & & $\mathrm{X}$ & \\
\hline 18 & & $\mathrm{X}$ & & & & $\mathrm{X}$ & \\
\hline 22 & & & $\mathrm{X}$ & & $\mathrm{X}$ & & \\
\hline 23 & & & & $\mathrm{X}$ & $\mathrm{X}$ & & \\
\hline 24 & & $\mathrm{X}$ & & & $\mathrm{X}$ & & \\
\hline 25 & & $\mathrm{X}$ & $\mathrm{X}$ & & & & \\
\hline 27 & $\mathrm{X}$ & & $\mathrm{X}$ & & & $\mathrm{X}$ & \\
\hline 29 & $\mathrm{X}$ & & $\mathrm{X}$ & & $\mathrm{X}$ & & \\
\hline 30 & $\mathrm{X}$ & & & $\mathrm{X}$ & & $\mathrm{X}$ & \\
\hline 32 & $\mathrm{X}$ & & & $\mathrm{X}$ & $\mathrm{X}$ & & \\
\hline 33 & & $\mathrm{X}$ & $\mathrm{X}$ & & & $\mathrm{X}$ & \\
\hline 34 & & $\mathrm{X}$ & $\mathrm{X}$ & & & & $\mathrm{X}$ \\
\hline 35 & & $\mathrm{X}$ & $\mathrm{X}$ & & $\mathrm{X}$ & & \\
\hline 36 & & $\mathrm{X}$ & & $\mathrm{X}$ & & $\mathrm{X}$ & \\
\hline 38 & & $\mathrm{X}$ & & $\mathrm{X}$ & $\mathrm{X}$ & & \\
\hline 39 & $\mathrm{X}$ & $\mathrm{X}$ & $\mathrm{X}$ & & & & \\
\hline 41 & $\mathrm{X}$ & $\mathrm{X}$ & & & & & $\mathrm{X}$ \\
\hline 42 & $\mathrm{X}$ & $\mathrm{X}$ & & & $\mathrm{X}$ & & \\
\hline 43 & $\mathrm{X}$ & $\mathrm{X}$ & & & $\mathrm{X}$ & & \\
\hline 44 & $\mathrm{X}$ & $\mathrm{X}$ & $\mathrm{X}$ & & & $\mathrm{X}$ & \\
\hline 45 & $\mathrm{X}$ & $\mathrm{X}$ & $\mathrm{X}$ & & & & $\mathrm{X}$ \\
\hline 46 & $\mathrm{X}$ & $\mathrm{X}$ & $\mathrm{X}$ & & $\mathrm{X}$ & & \\
\hline 47 & $\mathrm{X}$ & $\mathrm{X}$ & & $\mathrm{X}$ & & $\mathrm{X}$ & \\
\hline 49 & $\mathrm{X}$ & $\mathrm{X}$ & & $\mathrm{X}$ & $\mathrm{X}$ & & \\
\hline & & & & & & & \\
\hline
\end{tabular}

\footnotetext{
* SAS - Sulfuric acid soak

ChS - Chamise smoke
}

CS - Charate soak

LSS - Liquid smoke soak
$\mathrm{CF}$ - Charate field

LSF - Liquid smoke field 
Table 4. Second 2003-2004 Treatments Found to be the Best and Insignificantly Different from the Best.

\begin{tabular}{|c|c|c|c|c|c|c|c|}
\hline $\begin{array}{c}\text { Treatment } \\
\#\end{array}$ & Heat & SAS $^{*}$ & CS* & CF* & ChS* & LSS* & LSF* \\
\hline 8 & & & & & $\mathrm{X}$ & & \\
\hline 18 & & $\mathrm{X}$ & & & & $\mathrm{X}$ & \\
\hline 22 & & & $\mathrm{X}$ & & $\mathrm{X}$ & & \\
\hline 23 & & & & $\mathrm{X}$ & $\mathrm{X}$ & & \\
\hline 24 & & $\mathrm{X}$ & & & $\mathrm{X}$ & & \\
\hline 30 & $\mathrm{X}$ & & & $\mathrm{X}$ & & $\mathrm{X}$ & \\
\hline 32 & $\mathrm{X}$ & & & $\mathrm{X}$ & $\mathrm{X}$ & & \\
\hline 33 & & $\mathrm{X}$ & $\mathrm{X}$ & & & $\mathrm{X}$ & \\
\hline 35 & & $\mathrm{X}$ & $\mathrm{X}$ & & $\mathrm{X}$ & & \\
\hline 36 & & $\mathrm{X}$ & & $\mathrm{X}$ & & $\mathrm{X}$ & \\
\hline 38 & & $\mathrm{X}$ & & $\mathrm{X}$ & $\mathrm{X}$ & & \\
\hline 41 & $\mathrm{X}$ & $\mathrm{X}$ & & & & & $\mathrm{X}$ \\
\hline 43 & $\mathrm{X}$ & $\mathrm{X}$ & & & $\mathrm{X}$ & & \\
\hline 44 & $\mathrm{X}$ & $\mathrm{X}$ & $\mathrm{X}$ & & & $\mathrm{X}$ & \\
\hline 45 & $\mathrm{X}$ & $\mathrm{X}$ & $\mathrm{X}$ & & & & $\mathrm{X}$ \\
\hline 46 & $\mathrm{X}$ & $\mathrm{X}$ & $\mathrm{X}$ & & $\mathrm{X}$ & & \\
\hline 47 & $\mathrm{X}$ & $\mathrm{X}$ & & $\mathrm{X}$ & & $\mathrm{X}$ & \\
\hline 49 & $\mathrm{X}$ & $\mathrm{X}$ & & $\mathrm{X}$ & $\mathrm{X}$ & & \\
\hline
\end{tabular}

\section{Heat}

Figures 16A and B compare the mean number of chamise seeds that germinated with and without heat as a dormancy breaking treatment for 2002-2003 and 2003-2004, respectively. In 2002-2003, the mean number of chamise seeds that germinated following a heat treatment was significantly different than those that did not receive a heat treatment $(\mathrm{F}=11.43, \mathrm{df}=1, p$-value $=0.001)$. This significant difference appears to be largely a result of the lower number of seeds that germinated in plots receiving a heat treatment (Figure 16A). In 2003-2004, data indicate that there was no significant evidence for differences in chamise seed germination as a result of heat treatments $(\mathrm{F}=$ $3.83, \mathrm{df}=1, p$-value $=0.053)$. * SAS - Sulfuric acid soak
ChS - Chamise smoke
CS - Charate soak LSS - Liquid smoke soak
$\mathrm{CF}$ - Charate field

LSF - Liquid smoke field 

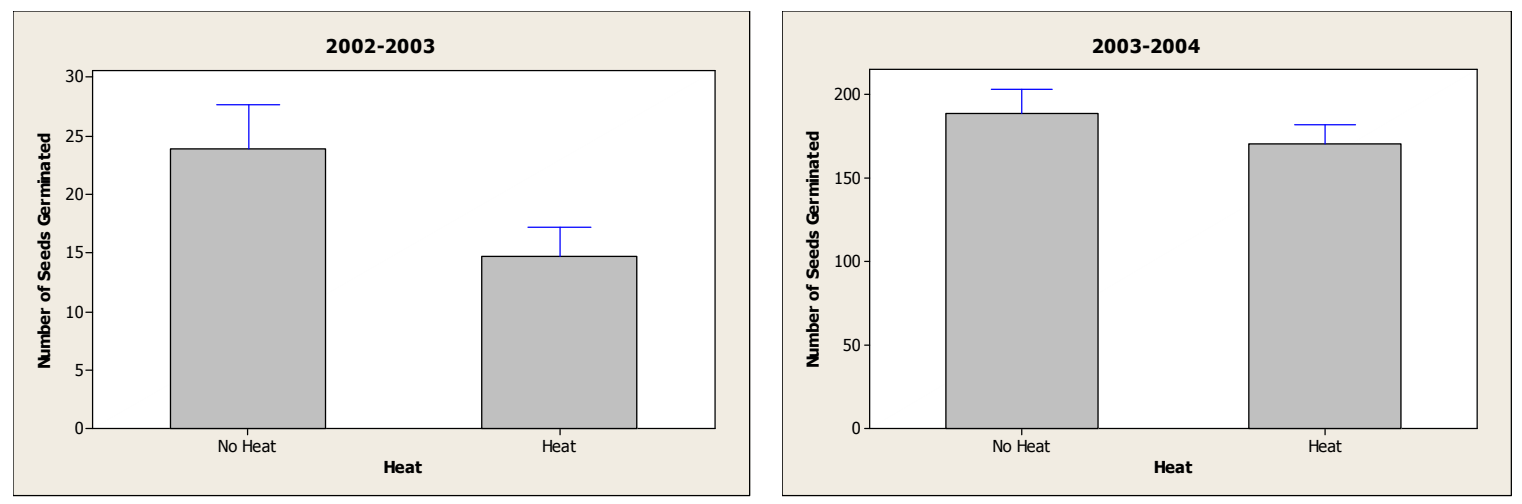

Figures 16A and 16B. Comparison of Seeds Germinated Without and With Heat. Error bars represent the standard error of the mean.

\section{Charate Soak}

Figures 17A and B compare of the mean number of chamise seeds that germinated with and without charate soak as a dormancy breaking treatment in 2002-2003 and 20032004, respectively. The 2002-2003 data indicate that there was no significant evidence for differences in chamise seed germination as a result of a charate soak treatment $(\mathrm{F}=$ $3.77, \mathrm{df}=1, p$-value $=0.055)$. However, the mean number of chamise seeds that germinated in 2003-2004 following a charate soak treatment differs significantly from the mean number of seeds that did not receive a charate soak treatment $(\mathrm{F}=6.71, \mathrm{df}=1, p$ value $=0.010$ ). This significant difference in germination appears to be the result of the higher number of seeds that germinated in plots receiving a charate soak treatment (Figure 17B). 

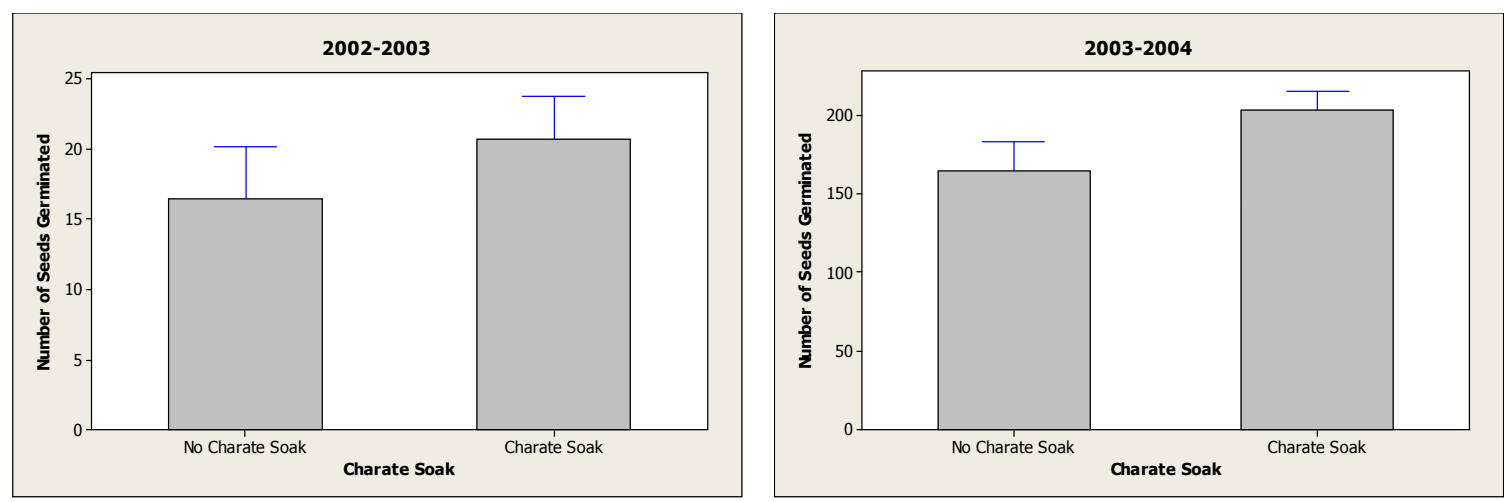

Figures 17A and 17B. Comparison of Seeds Germinated Without and With Charate Soak. Error bars represent the standard error of the mean.

\section{Charate Field}

Figures 18A and B compare of the mean number of chamise seeds that germinated with and without a charate field treatment to break dormancy in 2002-2003 and 20032004, respectively. The data showed that there was no significant evidence of a difference in chamise seed germination as a result of charate field treatments in either year $(\mathrm{F}=0.20, \mathrm{df}=1, p$-value $=0.658[2002-2003] ; \mathrm{F}=0.66, \mathrm{df}=1, p$-value $=0.419$ [2003-2004]).
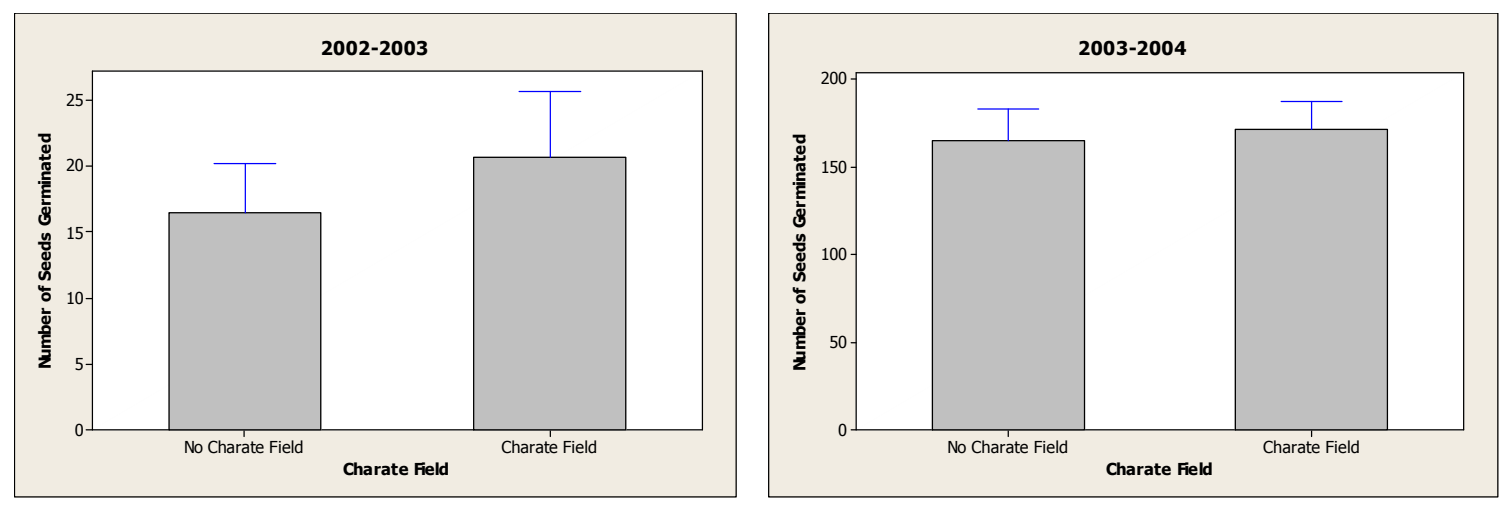

Figures 18A and 18B. Comparison of Seeds Germinated Without and With Charate Field. Error bars represent the standard error of the mean. 


\section{Liquid Smoke Soak}

Figures 19A and B compare of the mean number of chamise seeds that germinated with and without liquid smoke soak as a dormancy breaking treatment in 2002-2003 and 2003-2004, respectively. Data collected in 2002-2003 and 2003-2004 showed that the mean number of chamise seeds that germinated following a liquid smoke soak treatment differs significantly from the mean number of seeds that germinated without a liquid smoke soak treatment $(\mathrm{F}=119.73, \mathrm{df}=1, p$-value $=0.000$ [2002-2003]; $\mathrm{F}=103.10 \mathrm{df}=1$, $p$-value $=0.000$ [2003-2004]). This significant difference in germination appears to be the result of the higher number of seeds that germinated in plots receiving a liquid smoke soak treatment (Figures 19A and 19B).
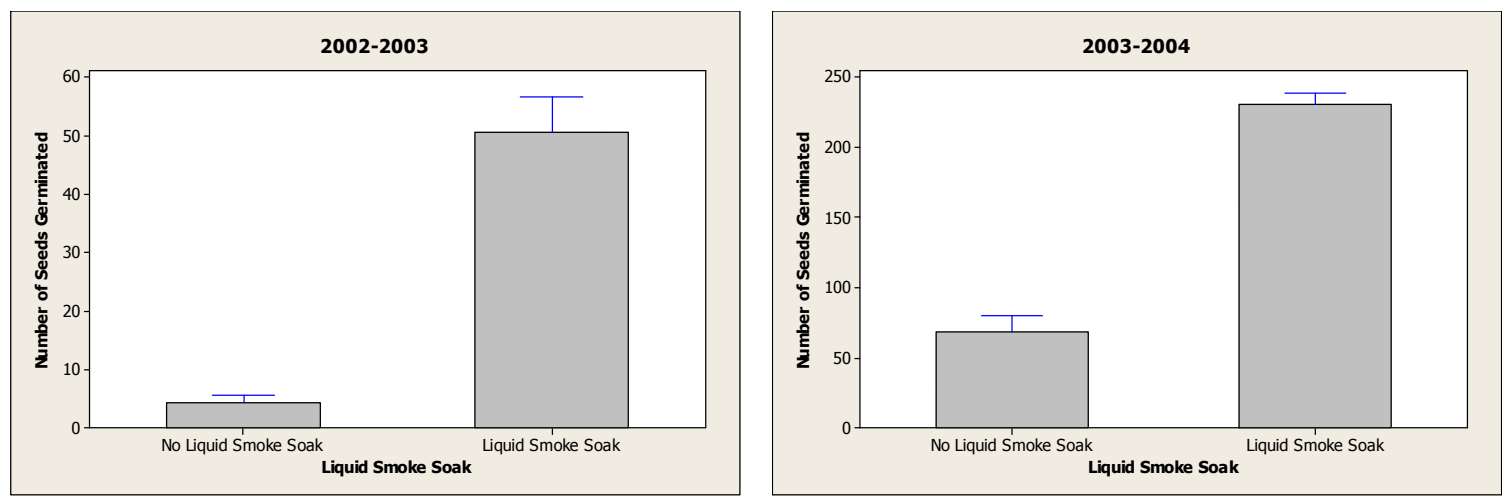

Figures 19A and 19B. Comparison of Seeds Germinated Without and With Liquid Smoke Soak. Error bars represent the standard error of the mean.

\section{Liquid Smoke Field}

Figures 20A and B compare of the mean number of chamise seeds that germinated with and without liquid smoke field as a dormancy breaking treatment for 2002-2003 and 2003-2004, respectively. In 2002-2003, data indicate that there was no significant evidence for differences in chamise seed germination as a result of a liquid smoke field treatment $(\mathrm{F}=1.29, \mathrm{df}=1, p$-value $=0.259)$. However, the mean number of chamise 
seeds that germinated in 2003-2004 following a liquid smoke field treatment differs significantly from the mean number of seeds that did not receive a liquid smoke field treatment $(\mathrm{F}=15.44, \mathrm{df}=1, p$-value $=0.000)$. This significant difference appears largely to be a result of an increase in the number of seeds germinated in plots receiving a liquid smoke field treatment (Figure 20B).
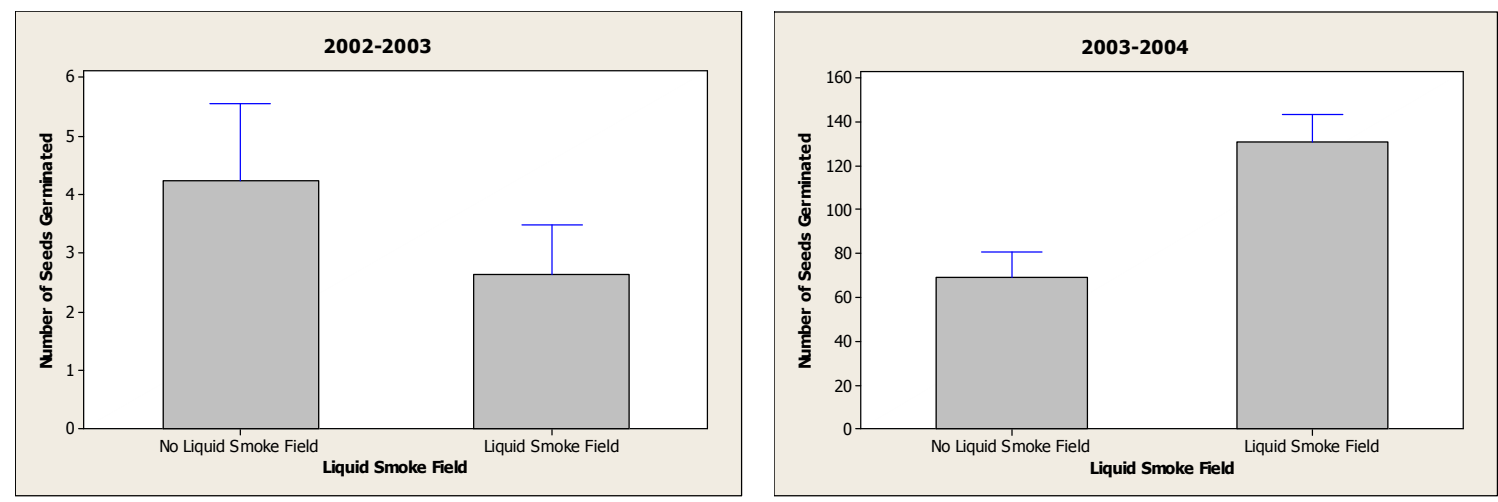

Figures 20A and 20B. Comparison of Seeds Germinated Without and With Liquid Smoke Field. Error bars represent the standard error of the mean.

\section{Chamise Smoke}

Figures 21A and B compare of the mean number of chamise seeds that germinated with and without chamise smoke as a dormancy breaking treatment for 2002-2003 and 2003-2004, respectively. The mean number of seeds that germinated in both years following chamise smoke treatment differs significantly from the mean number of germinated seeds that did not receive a chamise smoke treatment $(\mathrm{F}=54.93, \mathrm{df}=1, p$ value $=0.000[2002-2003] ; \mathrm{F}=147.73, \mathrm{df}=1, p$-value $=0.000[2003-2004])$. This significant difference appears largely to be a result of an increase in the number of seeds germinated in plots receiving a chamise smoke treatment (Figures 21A and 21B). 

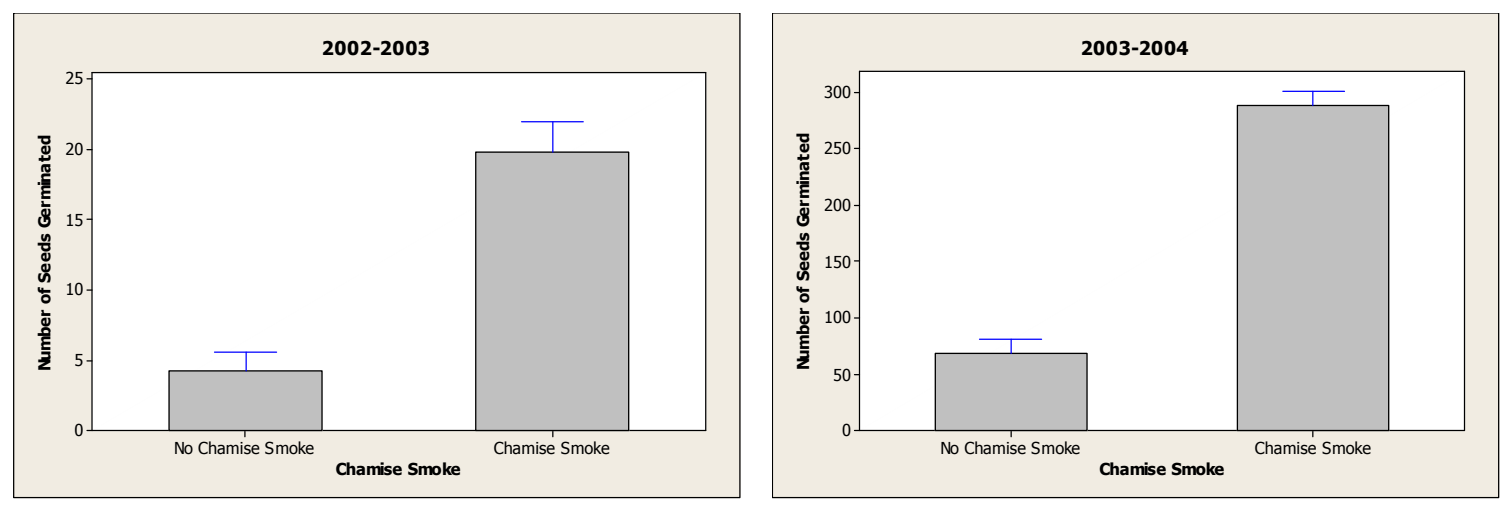

Figures 21A and 21B. Comparison of Seeds Germinated Without and With Chamise Smoke. Error bars represent the standard error of the mean.

\section{Sulfuric Acid Soak}

Figures $22 \mathrm{~A}$ and $\mathrm{B}$ compare of the mean number of chamise seeds that germinated with and without sulfuric acid soak as a dormancy breaking treatment for 2002-2003 and 2003-2004, respectively. In 2002-2003, data indicate that there was no significant evidence for differences in chamise seed germination as a result of a sulfuric acid soak treatment $(\mathrm{F}=0.00, \mathrm{df}=1, p$-value $=0.972)$. However, the mean number of seeds that germinated in 2003-2004 study following a sulfuric acid soak treatment differs significantly from the mean number of seeds that did not receive a sulfuric acid soak treatment $(\mathrm{F}=5.25, \mathrm{df}=1, p$-value $=0.024)$. Figure $22 \mathrm{~B}$ indicates that this significant difference appears largely to be a result of an increase in the number of seeds that germinated in plots receiving a sulfuric acid soak treatment. 

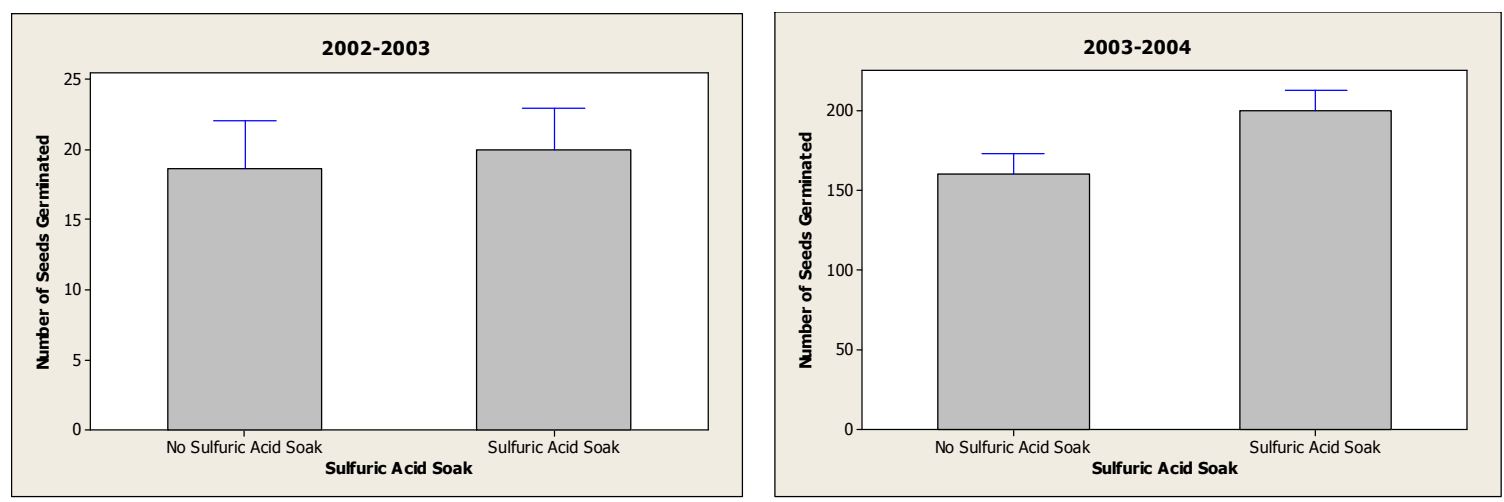

Figures 22A and 22B. Comparison of Seeds Germinated Without and With Sulfuric Acid Soak. Error bars represent the standard error of the mean.

\section{Heat and Charate Soak}

Figures $23 \mathrm{~A}$ and $\mathrm{B}$ show the results of seed germination rates with heat and charate soak as dormancy breaking treatments for 2002-2003 and 2003-2004, respectively. In both years, data indicate that there is no significant evidence that the effect of heat depends on the use of charate $\operatorname{soak}(\mathrm{F}=1.33, \mathrm{df}=1, p$-value $=0.252$ [2002-2003]; $\mathrm{F}=$ $0.02, \mathrm{df}=1, p$-value $=0.900[2003-2004])$.
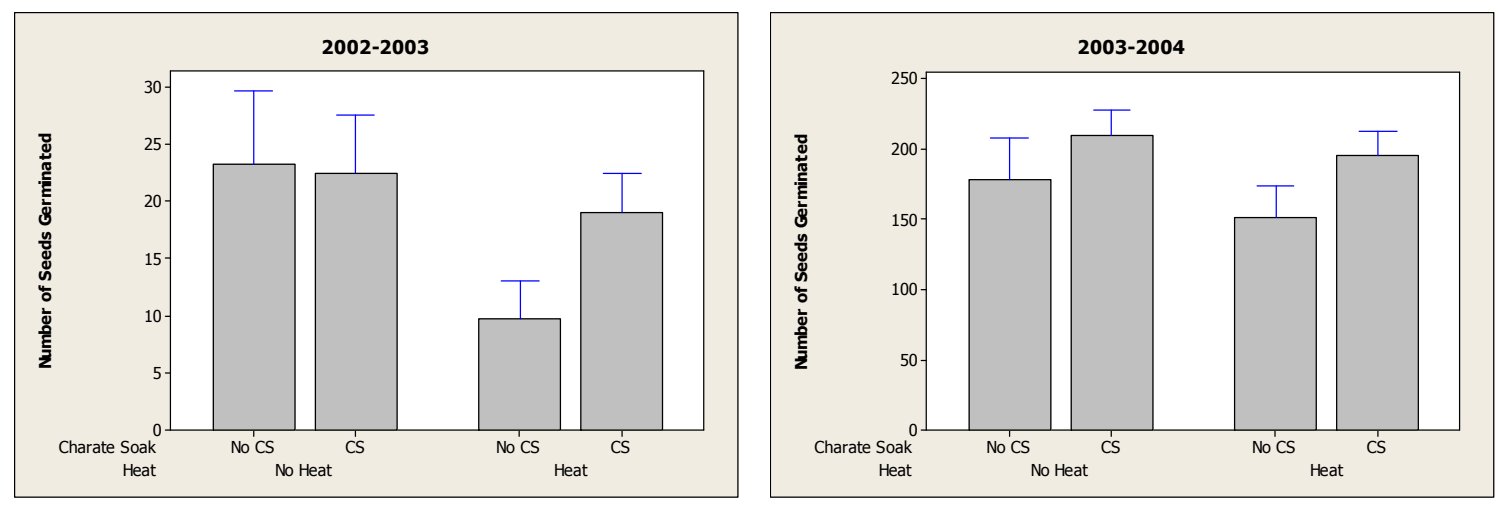

Figures 23A and 23B. Interaction between Heat and Charate Soak Treatments. Error bars represent the standard error of the mean.

\section{Heat and Charate Field}

Figures $24 \mathrm{~A}$ and $\mathrm{B}$ show the results of seed germination rates with heat and charate field as dormancy breaking treatments for 2002-2003 and 2003-2004, respectively. In 
both years, data indicate that there is no significant evidence that the effect of heat depends on the use of charate field $(\mathrm{F}=0.22, \mathrm{df}=1, p$-value $=0.321$ [2002-2003]; $\mathrm{F}=$ $0.09, \mathrm{df}=1, p$-value $=0.760[2003-2004])$.
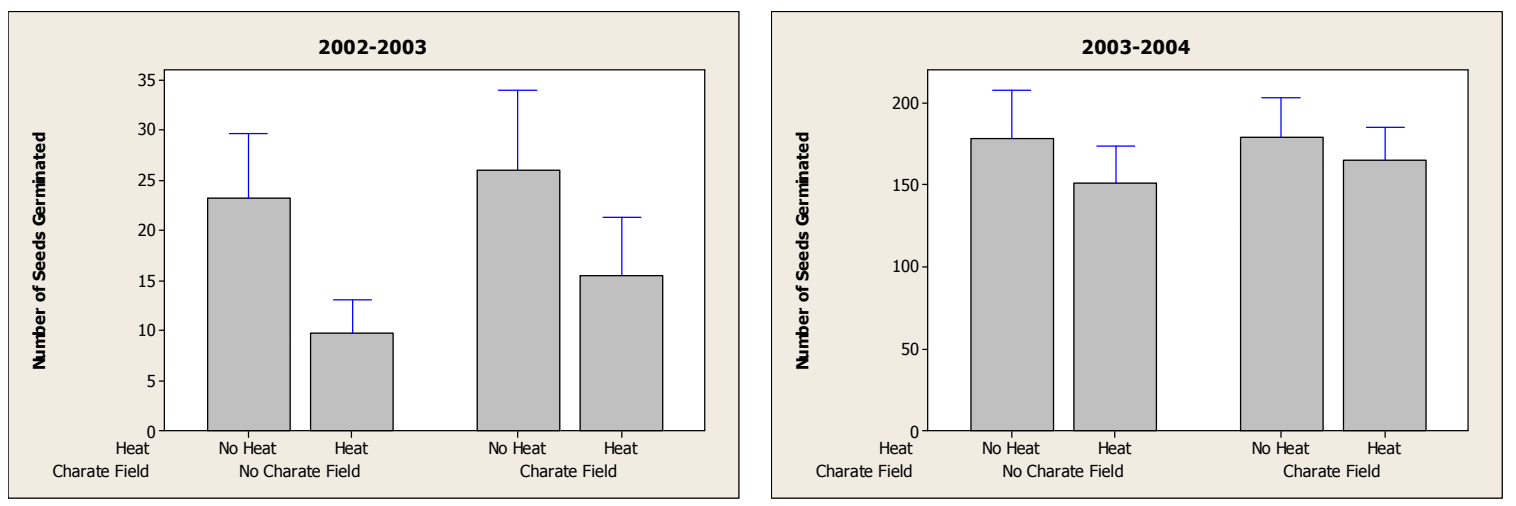

Figures 24A and 24B. Interaction between Heat and Charate Field Treatments. Error bars represent the standard error of the mean.

\section{Heat and Liquid Smoke Soak}

Figures $25 \mathrm{~A}$ and $\mathrm{B}$ show the results of seed germination rates with heat and liquid smoke soak as dormancy breaking treatments for 2002-2003 and 2003-2004, respectively. In 2002-2003, there is significant evidence that the effect of heat was dependent on the use of liquid smoke soak - the effect of liquid smoke soak was significantly lower when heat was used $(\mathrm{F}=14.61, \mathrm{df}=1, p$-value $=0.000)($ Figure 25A $)$. Post hoc comparisons using the Tukeys HSD test supports this in that the mean numbers of seeds germinated following a no heat/liquid smoke soak treatment was significantly different than a heat/liquid smoke soak treatment $(p$-value $=0.0002)$. In the 2003-2004 study there is no significant evidence that the effect of heat depended on the use of liquid smoke soak $(\mathrm{F}=0.32, \mathrm{df}=1, p$-value $=0.575)$. 

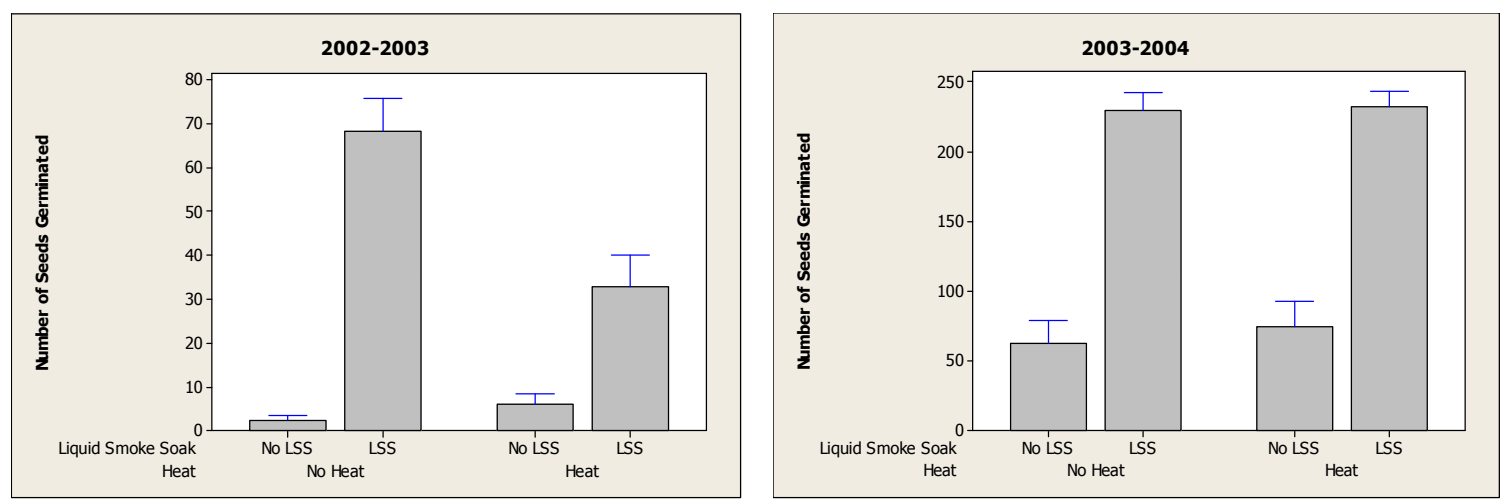

Figures 25A and 25B. Interaction between Heat and Liquid Smoke Soak Treatments. Error bars represent the standard error of the mean.

\section{Heat and Liquid Smoke Field}

Figures 26A and B show the results of seed germination rates with heat and liquid smoke field as dormancy breaking treatments for 2002-2003 and 2003-2004, respectively. In both years, data indicate that there is no significant evidence that the effect of heat depends on the use of liquid smoke field $(\mathrm{F}=0.03, \mathrm{df}=1, p$-value $=0.862$ [2002-2003]; $\mathrm{F}=0.72, \mathrm{df}=1, p$-value $=0.396$ [2003-2004]).
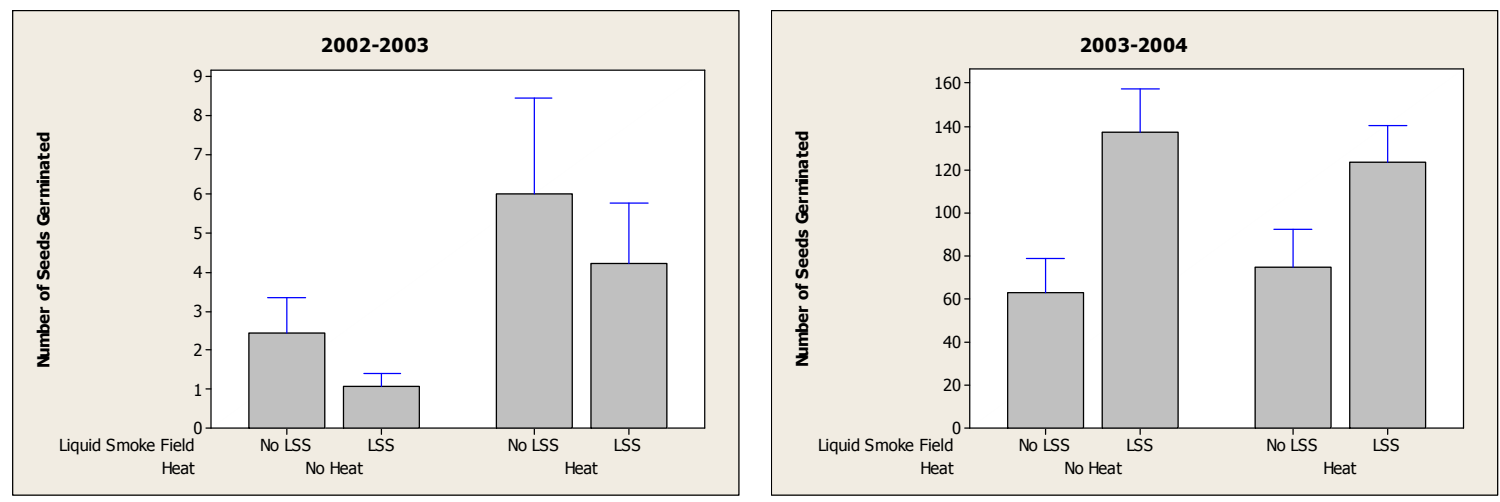

Figures 26A and 26B. Interaction between Heat and Liquid Smoke Field Treatments. Error bars represent the standard error of the mean.

\section{Heat and Chamise Smoke}

Figures $27 \mathrm{~A}$ and $\mathrm{B}$ show the results of seed germination rates with heat and chamise smoke as dormancy breaking treatments for 2002-2003 and 2003-2004, respectively. In 
2002-2003 there is significant evidence that the effect of heat was dependent on the use of chamise smoke $(\mathrm{F}=7.22, \mathrm{df}=1, p$-value $=0.009)$. A significant difference appears to be a result of a slight reduction in the number of seeds that germinated in plots that received both a chamise smoke treatment and a heat treatment and a slight increase in the number of seeds that just received a heat treatment, rather than a beneficial synergistic interaction between the two treatments (Figure 27A). Post hoc comparisons using the Tukeys HSD test supports this in that the mean numbers of seeds that germinated following a no heat/chamise smoke treatment was not significantly different than a heat/chamise smoke treatment $(p$-value $=0.0644)$. Also, in 2003-2004 there is significant evidence that the effect of heat was dependent on the use of chamise smoke ( $F=4.28$, $\mathrm{df}=1, p$-value $=0.002)$. A significant difference appears to be a result of the reduction in the number of seeds that germinated in plots that received both a chamise smoke and a heat treatment rather than a beneficial synergistic interaction between the two treatments (Figure 27B). Post hoc comparisons using the Tukeys HSD test supports this in that the mean numbers of seeds germinated following a no heat/chamise smoke treatment was significantly different than a heat/chamise smoke treatment $(p$-value $=0.0277)$.
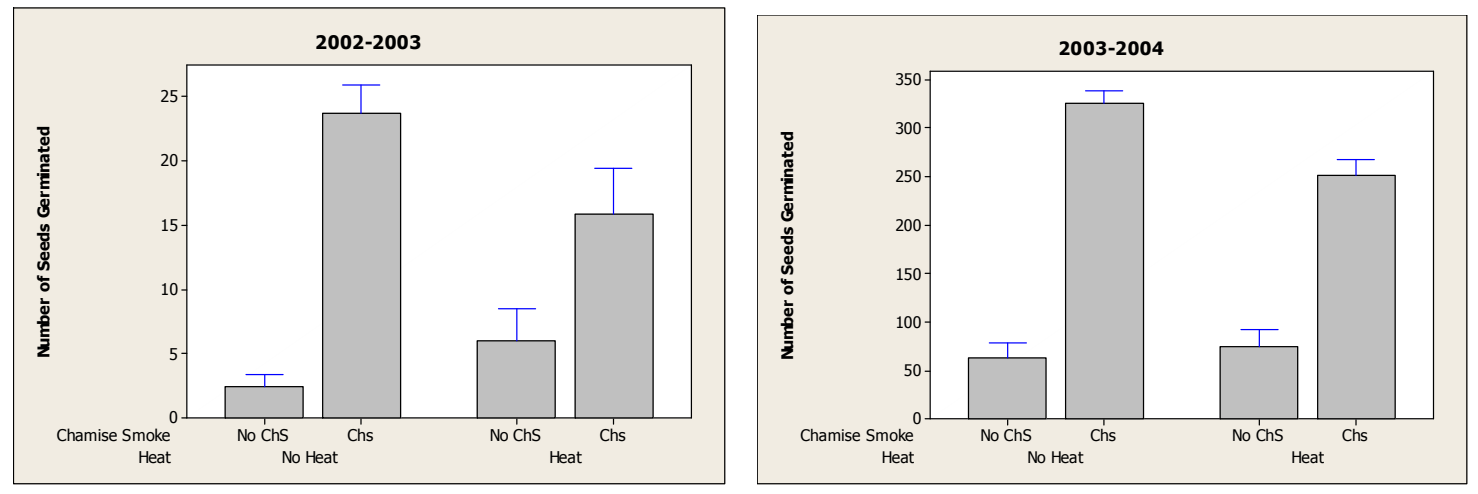

Figures 27A and 27B. Interaction between Heat and Chamise Smoke Treatments. Error bars represent the standard error of the mean. 


\section{Heat and Sulfuric Acid Soak}

Figures $28 \mathrm{~A}$ and B show the results of seed germination rates with heat and sulfuric acid soak as dormancy breaking treatments for 2002-2003 and 2003-2004, respectively. In both years, data indicate that there is no significant evidence that the effect of heat depends on the use of sulfuric acid soak $(\mathrm{F}=0.20, \mathrm{df}=1, p$-value $=0.454$ [2002-2003]; $\mathrm{F}$ $=0.96, \mathrm{df}=1, p$-value $=0.328[2003-2004])$.
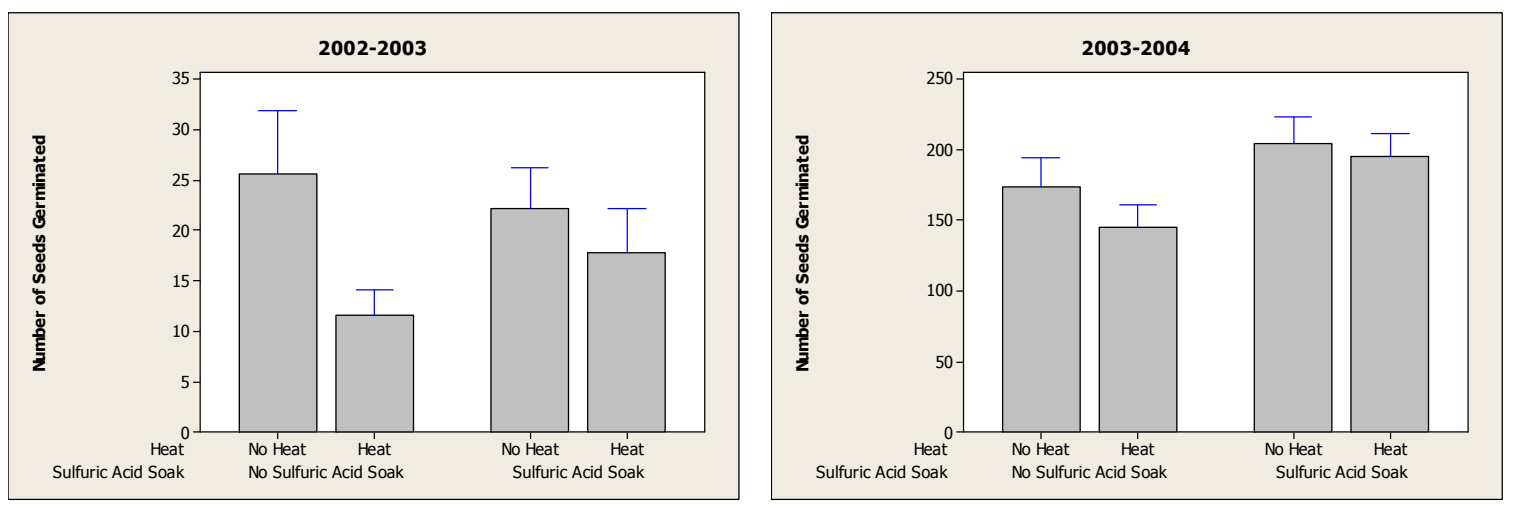

Figures 28A and 28B. Interaction between Heat and Sulfuric Acid Soak Treatments. Error bars represent the standard error of the mean.

\section{Charate Soak and Liquid Smoke Soak}

Figures 29A and B show the results of seed germination rates with charate soak and liquid smoke soak as dormancy breaking treatments for 2002-2003 and 2003-2004, respectively. The 2002-2003 data indicate that there is no significant evidence that the effect of charate soak depends on the use of liquid smoke soak $(\mathrm{F}=1.29, \mathrm{df}=1, p$-value $=$ 0.263). In 2002-2003, there is significant evidence that the effect of charate soak was dependent on the use of liquid smoke soak $(\mathrm{F}=29.10, \mathrm{df}=1, p$-value $=0.000)$. A significant difference appears to be a result of an increase in the number of seeds germinated in plots that received a charate soak treatment which did not received a liquid smoke soak treatment rather than a beneficial synergistic interaction between the two 
treatments (Figure 29B). Post hoc comparisons using the Tukeys HSD test supports this in that the mean numbers of seeds germinated following a no charate soak/no liquid smoke soak treatment was significantly different than a charate soak/no liquid smoke soak treatment $(p$-value $=0.0000)$. However, the no charate soak/liquid smoke soak treatment did not significantly differ from the charate soak/liquid smoke soak treatment $(p$-value $=0.9798)$.
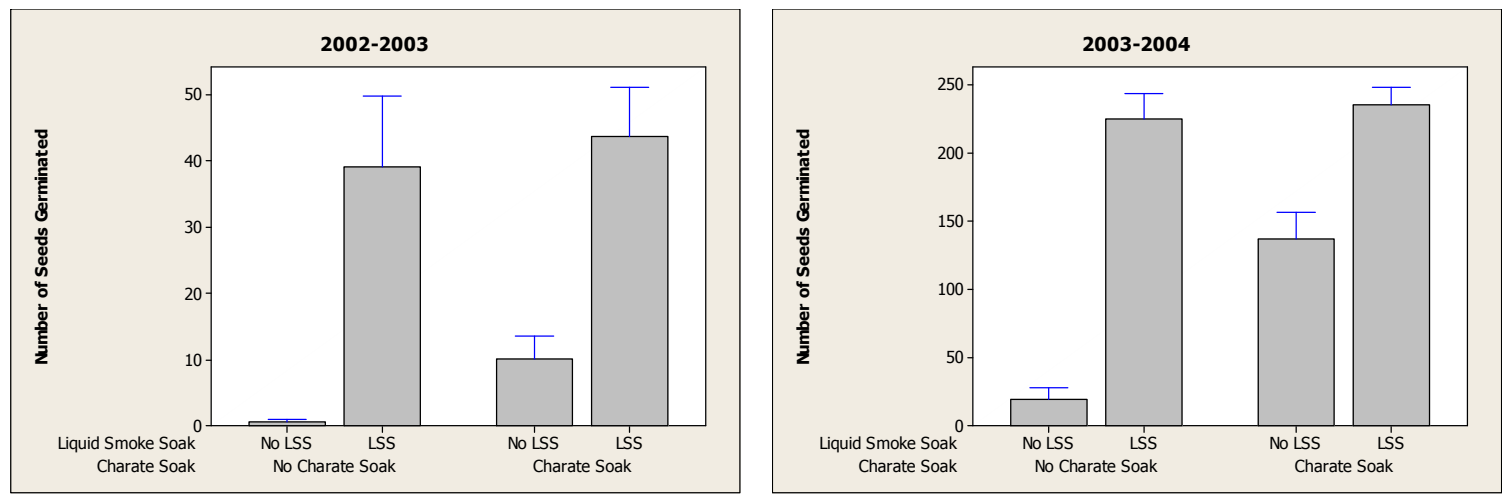

Figures 29A and 29B. Interaction between Charate Soak and Liquid Smoke Soak Treatments. Error bars represent the standard error of the mean.

\section{Charate Soak and Liquid Smoke Field}

Figures $30 \mathrm{~A}$ and $\mathrm{B}$ show the results of seed germination rates with charate soak and liquid smoke field as dormancy breaking treatments for 2002-2003 and 2003-2004, respectively. In the 2002-2003 data indicate that there is no significant evidence that the effect of charate soak depends on the use of liquid smoke field $(\mathrm{F}=2.75, \mathrm{df}=1, p$-value $=$ 0.104). In 2003-2004, there is significant evidence that the effect of charate soak was dependent on the use of liquid smoke field $(\mathrm{F}=9.23, \mathrm{df}=1, p$-value $=0.004)$. A significant difference appears to be a result of an increase in the number of seeds germinated in plots receiving a charate soak treatment which did not receive a liquid smoke field treatment rather than a beneficial synergistic interaction between the two 
treatments (Figure 30B). Post hoc comparisons using the Tukeys HSD test supports this in that the mean numbers of seeds germinated following a no charate soak/no liquid smoke field treatment was significantly different than a charate soak/no liquid smoke field treatment $(p$-value $=0.0000)$. However, the no charate soak/ liquid smoke field treatment did not significantly differ from the charate soak/liquid smoke field treatment $(p$-value $=0.4976)$.
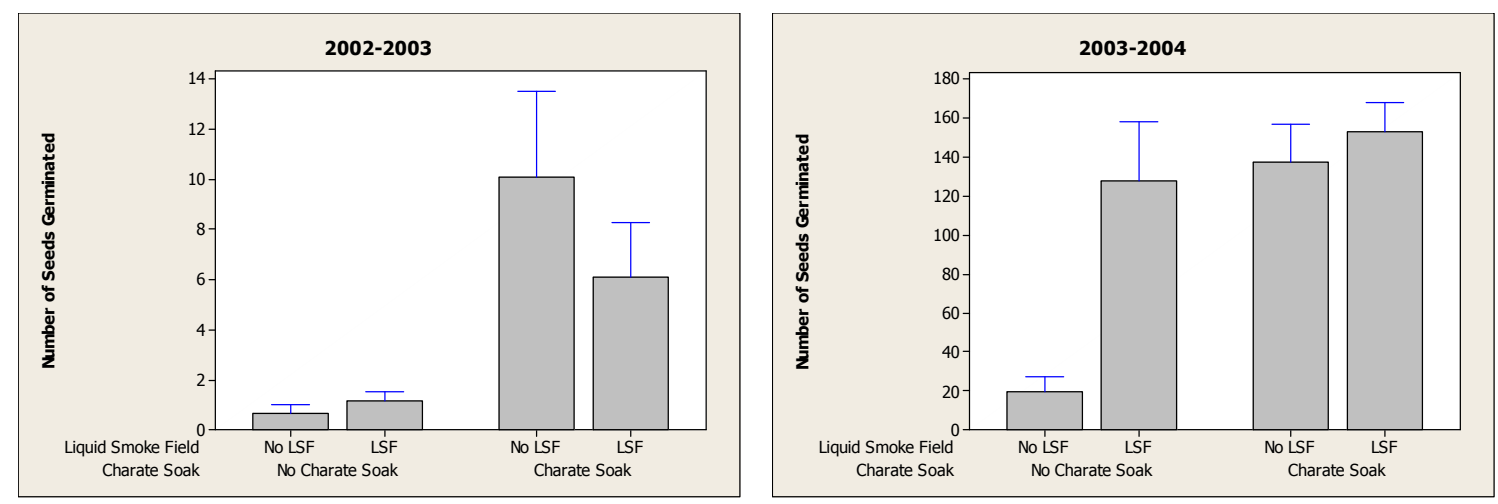

Figures 30A and 30B. Interaction between Charate Soak and Liquid Smoke Field Treatments. Error bars represent the standard error of the mean.

\section{Charate Soak and Chamise Smoke}

Figures $31 \mathrm{~A}$ and $\mathrm{B}$ show the results of seed germination rates with charate soak and chamise smoke as dormancy breaking treatments for 2002-2003 and 2003-2004, respectively. In 2002-2003, there is significant evidence that the effect of charate soak was dependent on the use of chamise smoke $(\mathrm{F}=8.04, \mathrm{df}=1, p$-value $=0.007)$. A significant difference appears to be a result of an increase in the number of seeds that germinated in plots receiving a charate soak treatment which did not receive a chamise smoke treatment rather that a beneficial synergistic interaction between the two treatments (Figure 31A). Post hoc comparisons using the Tukeys HSD test supports this in that the mean numbers of seeds germinated following a no charate soak/no chamise 
smoke treatment was significantly different than a charate soak/no chamise smoke treatment $(p$-value $=0.0015)$. However, the mean numbers of seeds germinated following the no charate soak/chamise smoke treatment did not significantly differ from the charate soak/chamise smoke treatment $(p$-value $=0.9999)$. Also, in 2003-2004, there is significant evidence that the effect of charate soak was dependent on the use of chamise smoke $(\mathrm{F}=25.30, \mathrm{df}=1, p$-value $=0.000)$. Once again, a significant difference appears to be a result of an increase in the number of seeds that germinated in plots receiving a charate soak treatment which did not receive a chamise smoke treatment rather that a beneficial synergistic interaction between the two treatments(Figure 31B). Post hoc comparisons using the Tukeys HSD test supports this in that the mean numbers of seeds germinated following a no charate soak/no chamise smoke treatment was significantly different than a charate soak/no chamise smoke treatment $(p$-value $=0.0000)$. However, the mean numbers of seeds germinated following the no charate soak/chamise smoke treatment did not significantly differ from the charate soak/chamise smoke treatment ( $p$ value $=1.000)$.
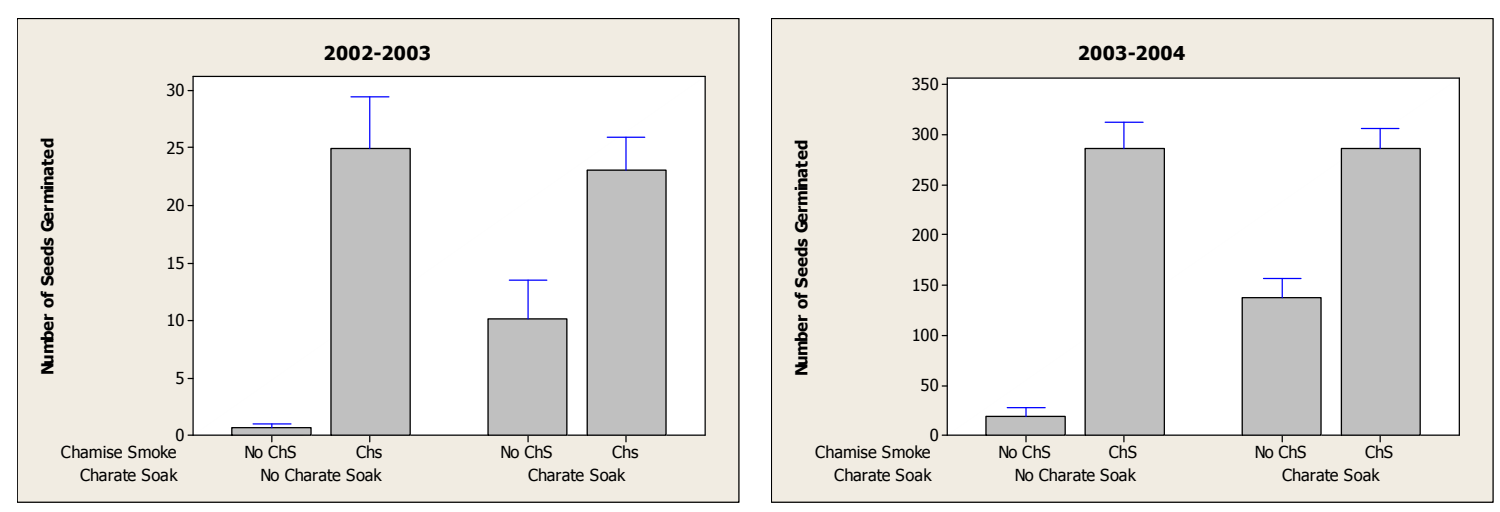

Figures 31A and 31B. Interaction between Charate Soak and Chamise Smoke Treatments. Error bars represent the standard error of the mean. 


\section{Charate Soak and Sulfuric Acid Soak}

Figures $32 \mathrm{~A}$ and $\mathrm{B}$ show the results of seed germination rates with charate soak and sulfuric acid soak as dormancy breaking treatments for 2002-2003 and 2003-2004, respectively. In the 2002-2003 study there is no significant evidence that the effect of charate soak depends on the use of sulfuric acid soak $(\mathrm{F}=0.55, \mathrm{df}=1, p$-value $=0.460)$. In 2003-2004, there is significant evidence that the effect of charate soak was dependent on the use of sulfuric acid soak $(\mathrm{F}=1.34, \mathrm{df}=1, p$-value $=0.250)$. A significant difference appears largely to be an increase in the number of seeds germinated from a synergistic interaction between the two treatments (Figure 32B). Post hoc comparisons using the Tukeys HSD test supports this in that the mean numbers of seeds germinated following a charate soak/sulfuric acid soak treatment was significantly different than a no charate soak/sulfuric acid soak treatment $(p$-value $=0.0406)$.
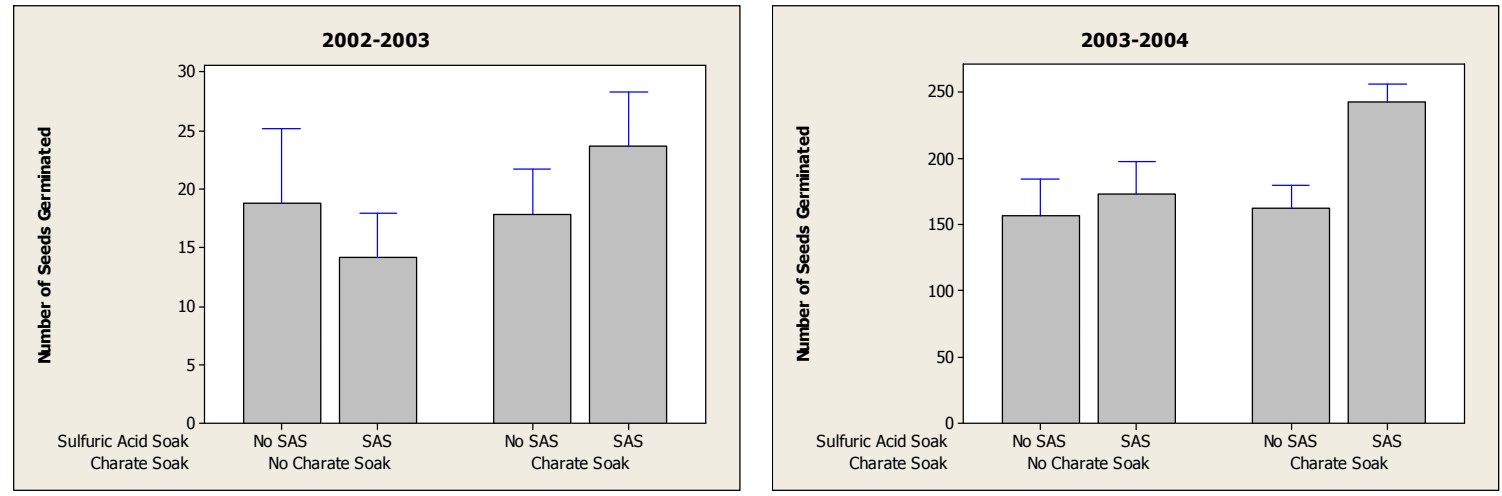

Figures 32A and 32B. Interaction between Charate Soak and Sulfuric Acid Soak Treatments. Error bars represent the standard error of the mean.

\section{Charate Field and Liquid Smoke Soak}

Figures $33 \mathrm{~A}$ and $\mathrm{B}$ show the results of seed germination rates with charate field and liquid smoke soak as dormancy breaking treatments for 2002-2003 and 2003-2004, respectively. In 2002-2003, there is significant evidence that the effect of charate field 
was dependent on the use of liquid smoke soak $(\mathrm{F}=2.78, \mathrm{df}=1, p$-value $=0.018)$. A significant difference appears to be an increase in the number of seeds that germinated following a synergistic interaction between the two treatments (Figure 33A). Post hoc comparisons using the Tukeys HSD test supports this in that the mean numbers of seeds germinated following a charate field/liquid smoke soak treatment was significantly different than both a no charate field/liquid smoke soak treatment $(p$-value $=0.0214)$ and a charate field/no liquid smoke soak treatment $(p$-value=0.0000). In the 2003-2004 study there is no significant evidence that the effect of charate field depends on the use of liquid smoke soak $(\mathrm{F}=3.79, \mathrm{df}=1, p$-value $=0.058)$.
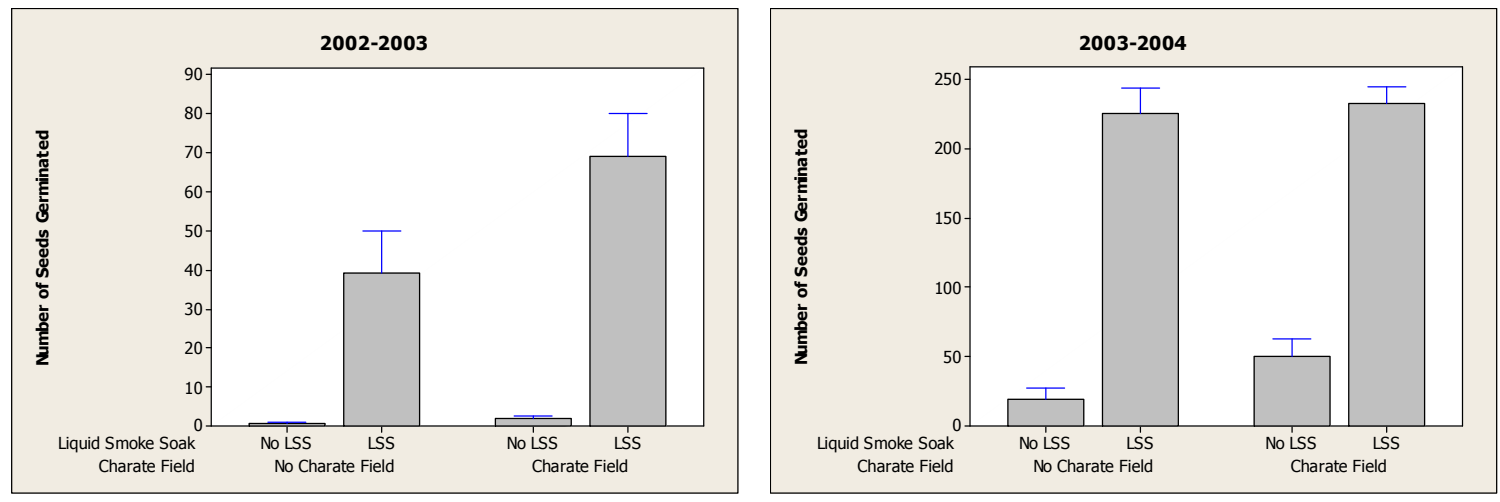

Figures 33A and 33B. Interaction between Charate Field and Liquid Smoke Soak Treatments. Error bars represent the standard error of the mean.

\section{Charate Field and Liquid Smoke Field}

Figures 34A and B show the results of seed germination rates with charate field and liquid smoke field as dormancy breaking treatments for 2002-2003 and 2003-2004, respectively. In both years, data indicate that there is no significant evidence that the effect of charate field depends on the use of liquid smoke field $(\mathrm{F}=4.01, \mathrm{df}=1, p$-value $=$ $0.051[2002-2003] ; \mathrm{F}=2.31, \mathrm{df}=1, p$-value $=0.136[2003-2004])$. 

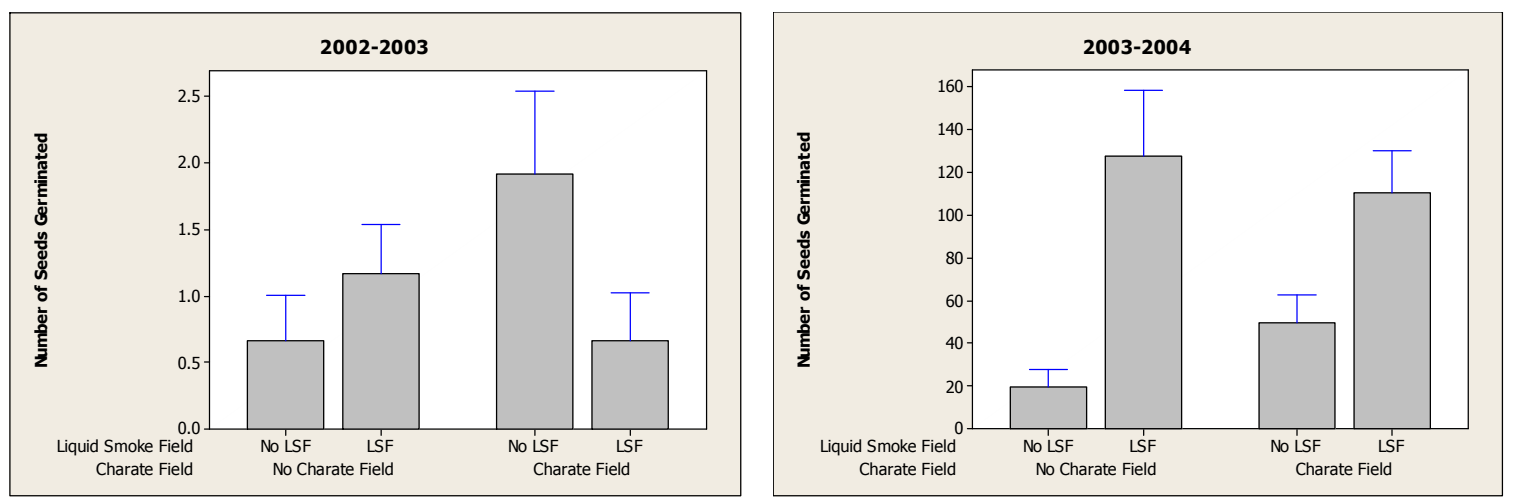

Figures 34A and 34B. Interaction between Charate Field and Liquid Smoke Field Treatments. Error bars represent the standard error of the mean.

\section{Charate Field and Chamise Smoke}

Figures $35 \mathrm{~A}$ and $\mathrm{B}$ show the results of seed germination rates with charate field and chamise smoke as dormancy breaking treatments for 2002-2003 and 2003-2004, respectively. In 2002-2003, there is significant evidence that the effect of charate field was dependent on the use of chamise smoke $(\mathrm{F}=8.24, \mathrm{df}=1, p$-value $=0.006) . \mathrm{A}$ significant difference appears to be a result of the reduction in the number of seeds that germinated in plots receiving a charate field treatment which also received a chamise smoke treatment rather that a beneficial synergistic interaction between the two treatments (Figure 35A). Post hoc comparisons using the Tukeys HSD test supports this in that the mean numbers of seeds germinated following a no charate field/chamise smoke treatment was significantly different than a charate field/chamise smoke treatment ( $p$-value $=0.0208)$. In 2003-2004, data indicate that there is no significant evidence that the effect of charate field depends on the use of chamise smoke $(\mathrm{F}=3.21, \mathrm{df}=1, p$-value $=0.080)$. 

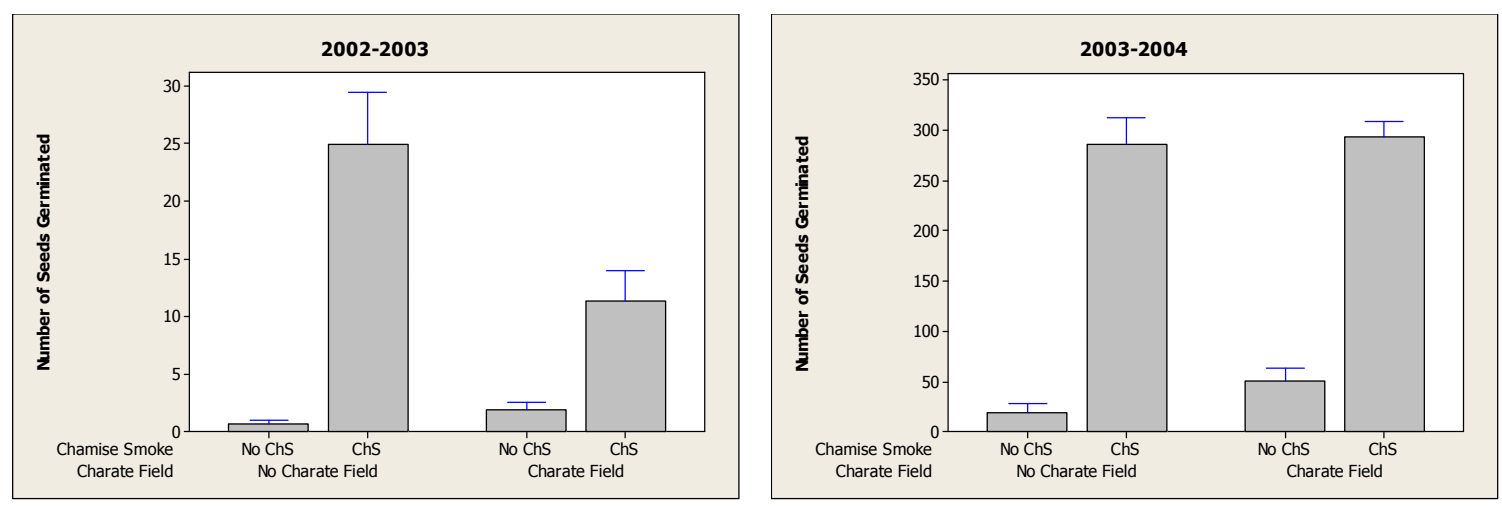

Figures 35A and 35B. Interaction between Charate Field and Chamise Smoke Treatments. Error bars represent the standard error of the mean.

\section{Charate Field and Sulfuric Acid Soak}

Figures $36 \mathrm{~A}$ and $\mathrm{B}$ show the results of seed germination rates with charate field and sulfuric acid soak as dormancy breaking treatments for 2002-2003 and 2003-2004, respectively. In both years, data indicate that there is no significant evidence that the effect of charate field depends on the use of sulfuric acid soak $(\mathrm{F}=0.94, \mathrm{df}=1, p$-value $=$ 0.655 [2002-2003]; $\mathrm{F}=0.00, \mathrm{df}=1, p$-value $=0.988$ [2003-2004]).
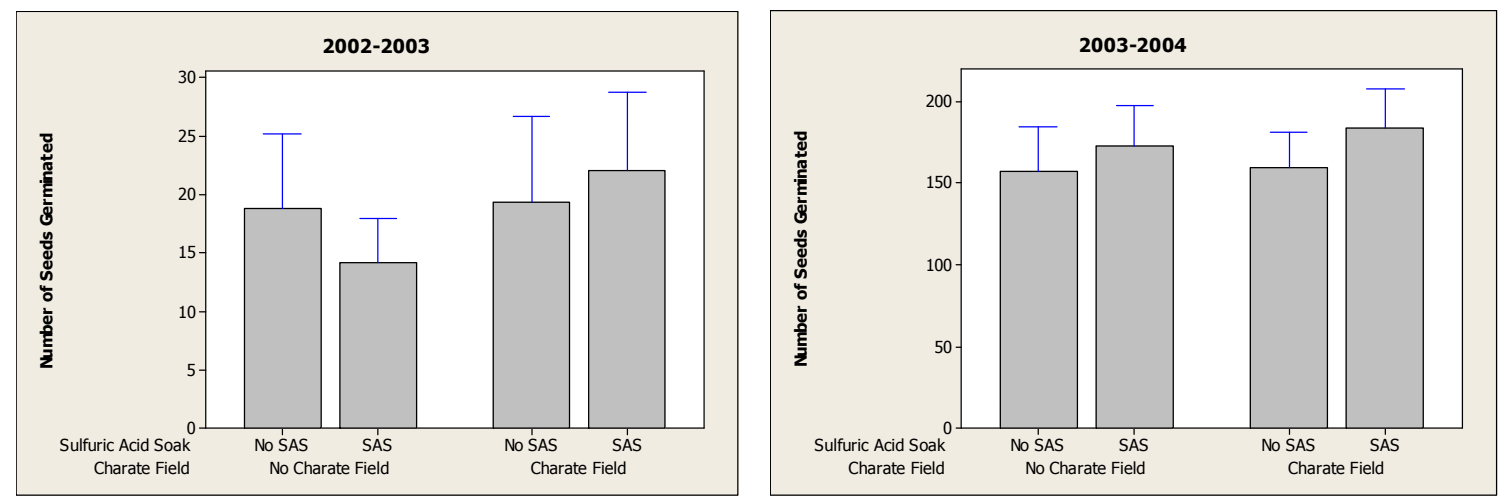

Figures 36A and 36B. Interaction between Charate Field and Sulfuric Acid Soak Treatments. Error bars represent the standard error of the mean.

\section{Liquid Smoke Soak and Sulfuric Acid Soak}

Figures $37 \mathrm{~A}$ and $\mathrm{B}$ show the results of seed germination rates with liquid smoke soak and sulfuric acid soak as dormancy breaking treatments for 2002-2003 and 2003- 
2004, respectively. In both years, data indicate that there is no significant evidence that the effect of liquid smoke soak depends on the use of sulfuric acid soak $(\mathrm{F}=2.72, \mathrm{df}=1$, $p$-value $=0.104[2002-2003] ; \mathrm{F}=0.16, \mathrm{df}=1, p$-value $=0.694[2003-2004])$.
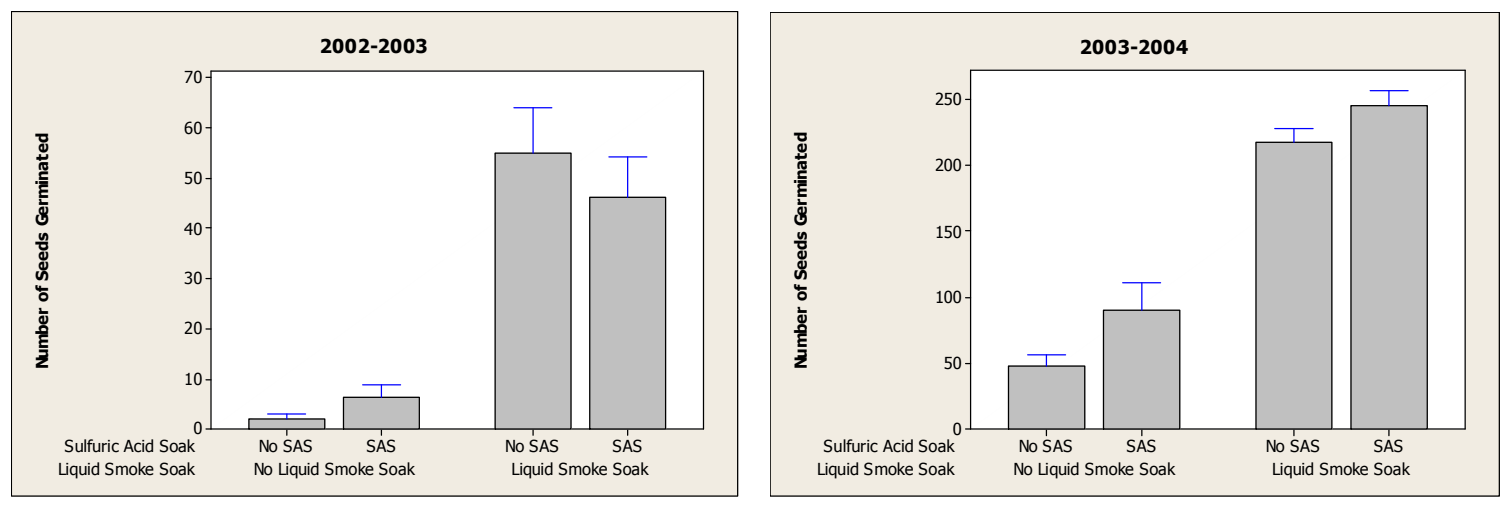

Figures 37A and 37B. Interaction between Liquid Smoke Soak and Sulfuric Acid Soak Treatments. Error bars represent the standard error of the mean.

\section{Liquid Smoke Field and Sulfuric Acid Soak}

Figures 38A and B show the results of seed germination rates with liquid smoke field and sulfuric acid soak as dormancy breaking treatments for 2002-2003 and 20032004, respectively. In both years, data indicate that there is no significant evidence that the effect of liquid smoke field depends on the use of sulfuric acid soak $(\mathrm{F}=1.68, \mathrm{df}=1$, $p$-value $=0.200$ [2002-2003]; $\mathrm{F}=0.24, \mathrm{df}=1, p$-value $=0.626[2003-2004])$.
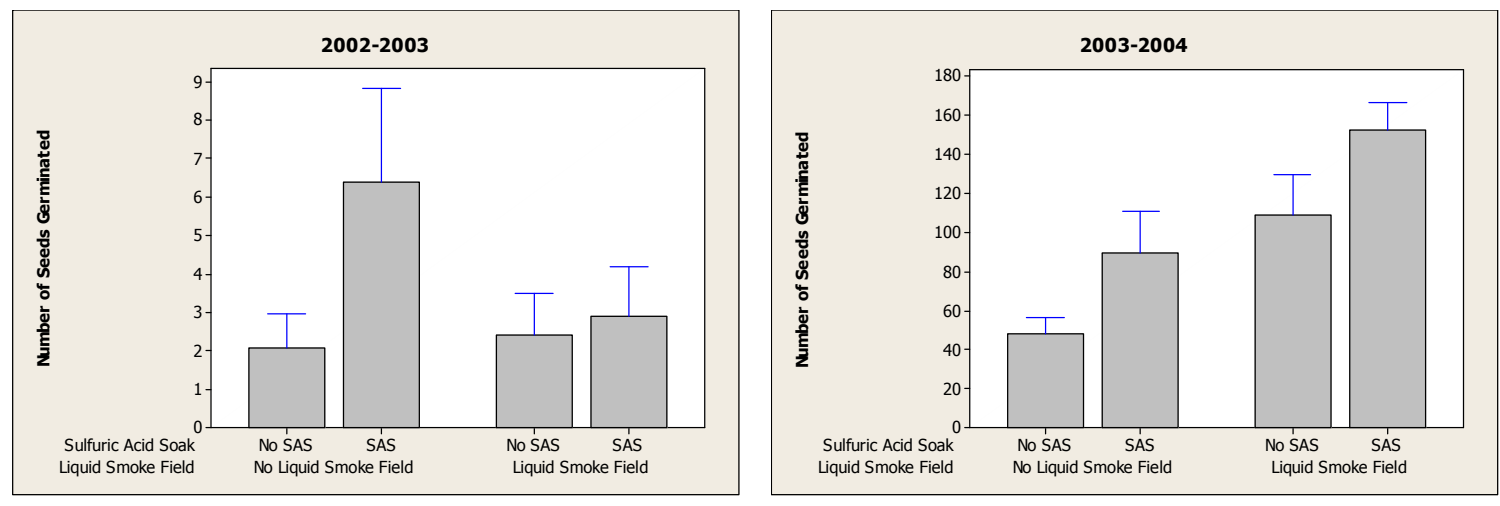

Figures 38A and 38B. Interaction between Liquid Smoke Field and Sulfuric Acid Soak Treatments. Error bars represent the standard error of the mean. 


\section{Chamise Smoke and Sulfuric Acid Soak}

Figures 39A and B show the results of seed germination rates with chamise smoke and sulfuric acid soak as dormancy breaking treatments for 2002-2003 and 2003-2004, respectively. In both years, data indicate that there is no significant evidence that the effect of chamise smoke depends on the use of sulfuric acid soak $(\mathrm{F}=0.02, \mathrm{df}=1, p$ value $=0.884[2002-2003] ; \mathrm{F}=0.00, \mathrm{df}=1, p$-value $=0.994[2003-2004])$.
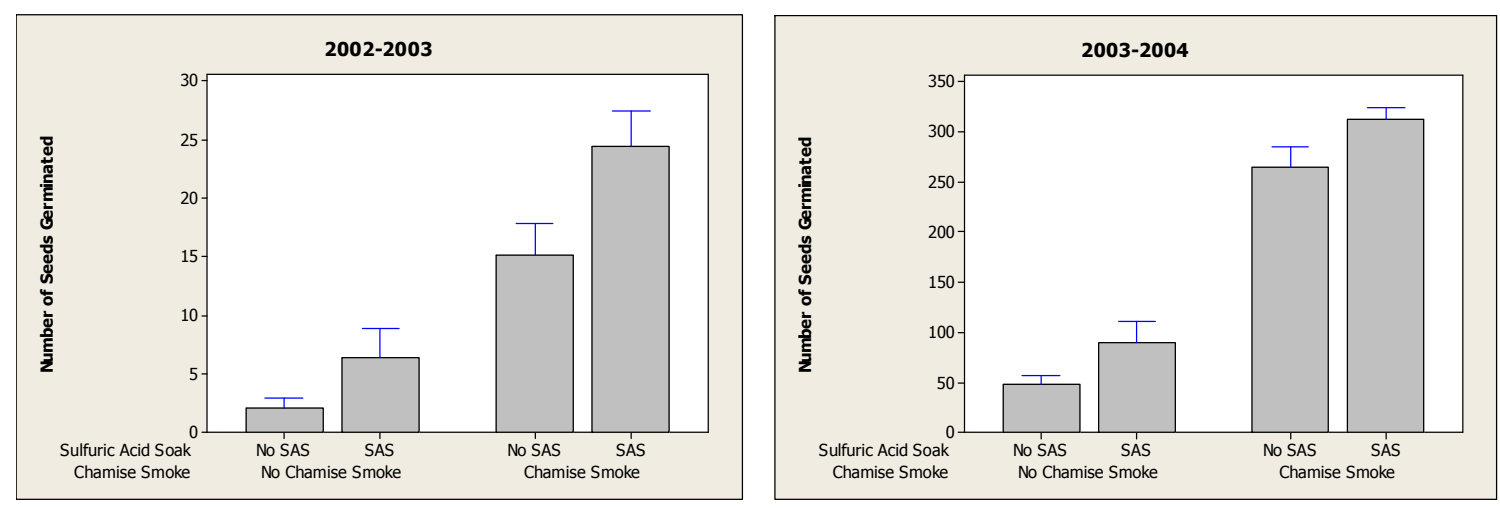

Figures 39A and 39B. Interaction between Chamise Smoke and Sulfuric Acid Soak Treatments. Error bars represent the standard error of the mean. 


\section{CHAPTER V}

\section{DISCUSSION}

The results of this study demonstrate that the germination rate of chamise seeds can be significantly increased under field conditions using specific dormancy breaking treatments. In 2002-2003 data analysis (using Hsu's MCB method) showed that six of the 49 treatments were found to be either the best treatment or insignificantly different from the best treatment. All six of these treatments included liquid smoke soak as a treatment. In 2003-2004, 18 of the 49 treatments were found to be either the best treatment or insignificantly different from the best treatment. Liquid smoke soak and chamise smoke were included in 16 of these 18 treatments.

Liquid smoke soak and chamise smoke both had a significant positive effect on the number of seeds germinated for both years of the experiment. Charate soak, liquid smoke field and sulfuric acid soak each resulted in a significant increase is chamise seed germination in the second year of the study but not during the first year. Heat showed no evidence of a significant effect on seed germination in the second year and appears to have decreased germination in the first year of the study. Charate field had no effect on seed germination in either year. 
None of the two way interactions examined showed a significant positive synergistic effect between treatments for both years of the study. The interaction between charate soak and sulfuric acid soak and the interaction between charate field and liquid smoke soak showed a significant positive synergistic effect in one year of the study but not both. For the majority of the interactions examined there was either no evidence of a synergistic effect between the treatments or the interactions appeared to cause a decrease in the number of seeds germinated.

In general, the statistical analysis indicates that the smoke related treatments of liquid smoke soak and chamise smoke have the greatest effect in increasing the germination rate of chamise seeds, and there is little to no benefit in subjecting the seeds to more than one treatment. The results generated in the Hsu's MCB test support this analysis. In 2002-2003 there was significant evidence that the solo treatment of liquid smoke soak was as effective in increasing germination as combining liquid smoke with other treatments. Similarly, in 2003-2004 there was no significant evidence of a difference between the plots that contained the solo treatment of liquid smoke soak or chamise smoke and the plots that received an additional treatment. This is an important consideration because it shows there is no significant reason to exert time or money on multiple treatments.

A substantial benefit in utilizing smoke treatments to break the dormancy of chamise seeds is the low cost and ease of treating the seeds. In order to be successful as a restoration tool, the technique must be applicable in real field conditions. Liquid smoke soak and chamise smoke were two of the quickest, easiest, and cheapest treatments to perform. Vast quantities of seeds could easily be subjected to natural smoke or soaked in 
a relativity small amount of smoke solution. Other treatments, such as the charate treatments, were much more labor intensive and the field treatments of charate field and liquid smoke field required so much product to treat the restoration area the costs would be astronomically higher. Yet, because so little research has been done on triggering germination in chaparral and chamise, treatments that were not successful at significantly increasing the germination rate should not be dismissed as potential tools. Understanding germination response to fire cues such as smoke or heat-shock is complicated by the fact that the same factors that stimulate germination at particular levels are lethal at higher levels. As discussed before, levels stimulatory to some species may be lethal to other species and levels stimulatory to some species may be insufficient to trigger germination in other species. Although heat appeared to be the least beneficial treatment in my study, additional research that explores a range of different temperatures and exposure times may find heat to be extremely beneficial.

It is my hope that the results of my research will help provide good inexpensive techniques to restore chamisal chaparral on mined slopes in California and that through the use of one or more of these techniques, restoration efforts on the finished slopes can closer resemble what would be observed after a natural fire disturbance in a chaparral community. 


\section{CHAPTER VI}

\section{LITERATURE CITED}

Axelrod, Daniel I. 1958. Evolution of the Madro-tertiary geoflora. Botanical Review 24(7): 433-509.

Baldwin, I. T., L. Staszak-Kozinski, and R. Davidson. 1994. Up in smoke. I. Smoke-derived germination cues for postfire annual, Nicotiana attenuata Torr. ex. Watson. Journal of Chemical Ecology 20:2345-2371.

Ballard, L. A. T. 1973. Physical barriers to germination. Seed Science and Technology 1:285303.

Barro, Susan C. and Conard, Susan G. 1987. Use of ryegrass seeding as an emergency revegetation measure in chaparral ecosystems. Gen. Tech. Rep.PSW-102. Berkeley, CA: U.S. Department of Agriculture, Forest Service, Pacific Southwest Forest and Range Experiment Station. $12 \mathrm{p}$.

Baskin, C.C. and J.M. Baskin 2001. Seeds: ecology, biogeography, and evolution of dormancy and germination. Academic Press, New York.

Baxter, B. J. M., J. van Staden, J. E. Granger, and N. A. C. Brown. 1994. Plant-derived smoke and smoke extracts stimulate seed germination of the fire-climax grass Themeda triandra. Environmental and Experimental Botany 34:217-223.

Bell, D. T., J. A. Plummer, and S. K. Taylor. 1993. Seed germination ecology in southwestern Western Australia. Botanical Review 59:24-73.

Berg AR. 1974. Arctostaphylos Adans., manzanita. In: Schopmeyer CS, tech. coord. Seeds of woody plants in the United States. Agric. Handbk. 450.

Bewley, J. D., and M. Black. 1982. Physiology and biochemistry of seeds in relation to germination. Volume 2. Viability, dormancy and environmental control. Springer-Verlag, New York, New York, USA. 
Biswell, H. H. 1961. Manipulation of chamise brush for deer range improvement. California Fish and Game. 47(2): 125-144.

Bolen, W.P., 2005, Sand and Gravel (construction): U.S. Geological Survey, Mineral Commodity Survey $2 \mathrm{p}$.

Bolsinger, Charles L. 1989. Shrubs of California's chaparral, timberland, and woodland: area, ownership, and stand characteristics. Res. Bull. PNW-RB-160. Portland, OR: U.S. Department of Agriculture, Forest Service, Pacific Northwest Experiment Station. 50 p.

Bradshaw, A.D. and M.J. Chadwick. 1980 The restoration of land: the ecology and reclamation of derelict and degraded land. UC Press, Berkeley, CA.

Brown, N. A. C. 1993. Promotion of germination of fynbos seeds by plant-derived smoke. New Phytologist 123:575-584.

Burne, H. M., C. J. Yates and P. G. Ladd. 2003. Comparative population structure and reproductive biology of the critically endangered shrub Grevillea althoferorum and two closely related more common congeners. Biol. Conserv., 114:53-65.

California Department of Conservation. 2006. Office of mine reclamation: What is Reclamation? http:www.consrv.ca.gov/OMR/reclamation/index.htm

California Department of Fish and Game. 2001. Seed dormancy and Treatment. Supplement to Native Species Planting Guide for the Elkhorn Slough National Estuarine. Research Reserve.18p.

Christensen, N.L. 1985. Shrubland fire regimes and their evolutionary consequences. In: Pickett, S.T.A.; White, P.S. (eds.) The ecology of natural disturbance and patch dynamics, p. 86-100. Academic Press, New York.

Christensen, N. I., and C. H. Muller. 1975a. Effects of fire on factors controlling plant growth in Adenostoma chaparral. Ecological Monographs. 45: 29-55.

Christensen, N. I., and C. H. Muller. 1975b. Relative importance of factors controlling germination and seedling survival in Adenostoma chaparral. American Midland Naturalist 93:71-78.

Claassen, V.P. and M. Marler. 1998. Annual and perennial grass growth on nitrogen depleted decomposed granite. Restoration Ecology 6:175-180

Claassen, V.P. and R.J. Zasoski. 1998 A comparison of plant available nutrients on decomposed granite cut slopes and adjacent natural soils. Land Degradation and Development 9:35-46

Conrad, C. Eugene. 1987. Common shrubs of chaparral and associated ecosystems of southern California. Gen. Tech. Rep. PSW-99. Berkeley, CA: U.S. Department of Agriculture, Forest Service, Pacific Southwest Forest and Range Experiment Station. 86 p. 
Conrad, C. Eugene. 1979. Emergency postfire seeding using annual grass. CHAPS Newsletter. Sacramento, CA: California Department of Forestry, Chaparral Research and Development Program. March: 5-8.

Cooper, W. S. 1922. The broad-sclerophyll vegetation of California. Publ. No. 319. Washington, DC: The Carnegie Institution of Washington. 145 p.

Dale, Nancy. 1986. Flowering plants: The Santa Monica Mountains, coastal and chaparral regions of southern California. Santa Barbara, CA: Capra Press. In cooperation with: The California Native Plant Society. 239 p.

D'Antonio, C.M., Odion, D.C. and C.M. Tyler. 1993. Invasion of maritime chaparral by the introduced succulent Carpobrotus edulis. Oecologia 95: 14-21.

Davey, J.R. 1982. Stand replacement in Ceanothus crassifolius. M.S. Thesis, California Polytechnic Univ., Pomona.

Davis, Frank W., Borchert, Mark I. and Odion, Dennis C. 1989. Establishment of microscale vegetation pattern in maritime chaparral after fire. Vegetatio. 84: 53-67.

Dayton, William A. 1931. Important Western Browse plants. Misc. Publ. 101. Washington, DC: U.S. Department of Agriculture. 214 p. (768)

De La Rosa-Ibarra M and Garcia H. 1994. Stimulation of germination on five species of cacti in danger of extinction. Phyton (Buenos Aires) 56, 147-50. Contact: Dep. Botanica, Universidad Autonoma Agraria, Saltillo, Coahuila, Mexico CP 25000, Mexico

di Castri, F. and Mooney, H.A. Mediterranean-type Ecosystems: Origin and Function. New York, Heidelberg, and Berlin: Springer-Verlag. 1973. 390 p.

Dixon, K. W., S. Roche, and J. S. Pate. 1995. The promotive effect of smoke-derived from burnt native vegetation on seed germination of Western Australian plants. Oecologia 101:185-192.

Egley, G. H. 1989. Water-impermeable seed coverings as barriers to germination. in R. B. Taylorson, editor. Recent advances in the development and germination of seeds. Plenum, New York, New York, USA. Pages 207-223

Evans, E. and F.A. Blazich. 1999. Overcoming seed dormancy: Trees and shrubs. N.C. Coop. Ext. Serv. Hort. Info. Lflt. 8704.

Flematti, G. R., E. L. Ghisalberti, K. W. Dixon and R. D. Trengove. 2004. A compound from smoke that promotes seed germination. Science, 305:977

Florence, Melanie. 1987. Plant succession on prescribed burn sites in chamise chaparral. Rangelands. 9(3): 119-122. 
Gautier, Clayton R. 1983. Sedimentation in burned chaparral watersheds: is emergency revegetation justified?. Water Resources Bulletin. 19(5): 793-802.

Gill, A. M., R. H. Groves, and I. R. Noble. 1981. (eds.). Fire and the Australian biota. Australian Academy of Science, Canberra.

Godínez-Alvarez, H. and Valiente-Banuet, A. 1998. Germination and early seedling growth of Tehuacan Valley cacti species: the role of seed ingestion by dispersers and soil on seedling growth. Journal of Arid Environments 39:21-3

Goldammer, J.G., ed. 1990. Fire in the tropical biota. Ecosystem processes and global challenges. Ecological Studies Vol. 84. Berlin-Heidelberg-New York, Springer-Verlag.

Greiner, Inc. 1994. Draft Rocky Canyon Quarry Specific Plan, prepared for Union Asphalt, Inc. for submittal to San Luis Obispo County

Griffin, James R. 1974. Notes on environment, vegetation and flora: Hastings Natural History Reservation. Memo Report. On file at: U.S. Department of Agriculture, Forest Service, Intermountain Research Station, Fire Sciences Laboratory, Missoula, MT. 90 p.

Hanes, Ted L. 1965. Ecological studies on two closely related chaparral shrubs in southern California. Ecological Monograph. 35(2): 213-235.

Hanes, Ted L. 1971. Succession after fire in the chaparral of southern California. Ecological Monographs. 41(1): 27-52.

Hanes, Ted L. 1974. The vegetation called chaparral. In: Rosenthal, Murray, ed. Symposium on living with the chaparral: Proceedings; 1973 March 30-31; Riverside, CA. San Francisco, CA: The Sierra Club: 1-5.

Hanes, Ted L. 1977. California chaparral. In: Barbour, Michael G.; Major, Jack, eds. Terrestrial vegetation of California. New York: John Wiley and Sons: 417-469.

Hanes, Ted L. 1981. California chaparral. In: Di Castri, F.; Goodall, D. W.; Specht, R. L., eds. Mediterranean-type shrublands. Amsterdam: Elsevier Science Publishers B.V: 139-174.

Hanes, Ted L. 1982. Vegetation classification and plant community stability: a summary and synthesis. In: Conrad, C. Eugene; Oechel, Walter C., technical coordinators. Proceedings of the symposium on dynamics and management of Mediterranean-type ecosystems; 1981 June 22-26; San Diego, CA. Gen. Tech. Rep. PSW-58. Berkeley, CA: U.S. Department of Agriculture, Forest Service, Pacific Southwest Forest and Range Experiment Station: 106-111.

Hanes, Ted L.; Jones, Harold W. 1967. Postfire chaparral succession in southern California. Ecology. 48(2): 259-264. 
Hedrick, Donald W. 1951. Studies on the succession and manipulation of chamise brushlands in California. College Station, TX: Texas Agricultural and Mechanical College. 113 p. Dissertation.

Hellmers, H.; Horton, J. S.; Juhren, G.; O'Keefe, J. 1955. Root systems of some chaparral plants in southern California. Ecology. 36(4): 667-678.

Holland, V.L. 1996. Botanical report and revegetation plan for expanded Rocky Canyon Quarry. Unpubl. rep. prepared for Willco-Hermreck, Santa Maria, California.

Holland, V. L. and David J. Keil. 1995. California Vegetation. Kendall/Hunt Publishing Company. Dubuque, Iowa

Horton, Jerome S. 1949. Trees and shrubs for erosion control of southern California mountains. Berkeley, CA: U.S. Department of Agriculture, Forest Service, California [Pacific Southwest] Forest and Range Experiment Station; California Department of Natural Resources, Division of Forestry. 72 p.

Horton, Jerome S. 1960. Vegetation types of the San Bernardino Mountains. Tech. Rep. PSW44. Berkeley, CA: U.S. Department of Agriculture, Forest Service, Pacific Southwest Forest and Range Experiment Station. 29 p.

Horton, J. S.; Kraebel, C. J. 1955. Development of vegetation after fire in the chamise chaparral of southern California. Ecology. 36(2): 244-262.

Howe, George F. 1981. Death of chamise (Adenostoma fasciculatum) shrubs after fire or cutting as a result of herbivore browsing. Bulletin of the Southern California Academy of Sciences. 80(3): 138-143.

Jager, A. K., Light, M. E. and Van Staden, J. 1996. Temperature and source of plant material effects the production of smoke that promotes seed germination. Env. Exp. Bot. 36: 421429.

Johnson-Maynard J, Anderson MA, Green S, Graham RC (1994) Physical and hydraulic properties of granitic rock in southern California. Soil Sci 158:375-380

Jones, C. S., and W. H. Schlesinger. 1980. Emmenanthe penduliflora (Hydrophyllaceae): further consideration of germination response. Madrono 27:122-125.

Jones DP, Graham RC (1993) Water-holding characteristics of weathered granitic rock in chaparral and forest ecosystems. Soil Sci Soc Am J 57:256-261

Keeley, Jon E. 1977. Fire-dependent reproductive strategies in Arctostaphylos and Ceanothus. In: Mooney, Harold A.; Conrad, C. Eugene, technical coordinators. Symposium on the environmental consequences of fire and fuel management in Mediterranean ecosystems: Proceedings; 1977 August 1-5; Palo Alto, CA. Gen. Tech. Rep. WO-3. Washington, DC: U.S. Department of Agriculture, Forest Service: 391-396. [4868] 
Keeley, Jon E. 1981. Reproductive cycles and fire regimes. In: Mooney, H. A.; Bonnicksen, T. M.; Christensen, N. L.; [and others], technical coordinators. Fire regimes and ecosystem properties: Proceedings of the conference; 1978 December 11-15; Honolulu, HI. Gen. Tech. Rep. WO-26. Washington, DC: U.S. Department of Agriculture, Forest Service: 231-277.

Keeley, Jon E. 1984. Factors affecting germination of chaparral seeds. Bulletin of the Southern California Academy of Sciences. 83(3): 113-120.

Keeley, Jon E. 1986. Resilience of Mediterranean shrub communities to fires. In: Dell, B.; Hopkins, A. J. N.; Lamont B. B., editors. Resilience in Mediterranean-type ecosystems. Dordrecht, the Netherlands: Dr. W. Junk Publishers: 95-112.

Keeley, J. E. 1987. Role of fire in seed germination of woody taxa in California chaparral. Ecology 68:434- 443.

Keeley, J. E. 1991. Seed germination and life history syndromes in the California chaparral. Botanical Review 57:81-116.

Keeley, J. E. 1992. A Californian's view of fynbos. Pages 372- 388 in R. M. Cowling, editor. The ecology of fynbos. Oxford University Press, Cape Town, South Africa.

Keeley, J. E., and C. J. Fotheringham. 1997. Trace gas emissions and smoke-induced seed germination. Science 276: 1248-1250.

Keeley, J. E., and C. J. Fotheringham. 1998. Mechanism of smoke-induced seed germination in a post-fire chaparral annual. Journal of Ecology 86:27-36.

Keeley, J.E. and S.C. Keeley. 1984. Post-fire recovery of California coastal sage scrub. American Midland Naturalist 111:105-117.

Keeley, J.E. and S.C. Keeley. 1987. The role of fire in the germination of chaparral herbs and suffrutescents. Madroño 34:240 249.

Keeley, J.E. and S.C. Keeley. 1988. Chaparral, pp. 165-207. In M.G. Barbour and W.D. Billings (eds), North American terrestrial vegetation. Cambridge University Press, Cambridge, U.K.

Keeley, J.E. and S.C. Keeley. 1989. Allelopathy and the fire induced herb cycle, pp. 65-72. In S. Keeley (ed), California Chaparral: Paradigms Re-examined. Natural History Museum of Los Angeles County, Science Series No. 34, Los Angeles, CA

Keeley, J.E. and M.B. Keeley. 1999. Role of charred wood, heat-shock and light in germination of postfire phrygana species from the eastern Mediterranean Basin. Israel Journal of Plant 47:11-16.[Journal Article]

Keeley, J.E., T. McGinnis and K.A. Bollens. 2005. Seed germination of Sierra Nevada postfire chaparral species. Madroño 52:175-181. 
Keeley, J.E., B.A. Morton, A. Pedrosa, and P. Trotter. 1985. Role of allelopathy, heat and charred wood in the germination of chaparral herbs and suffrutescents. Journal of Ecology 73:445-458.

Keeley, J.E. and M.E. Nitzberg. 1984. The role of charred wood in the germination of the chaparral herbs Emmenanthe penduliflora (Hydrophyllaceae) and Eriophyllum confertiflorum (Asteraceae). Madroño 31:208-218.

Keeley, S. C. and M. Pizzorno. 1986. Charred wood stimulated germination of two firefollowing herbs of the California chaparral and the role of hemicellulose. American Journal of Botany 73:1289-1297.

Keeley, J. E. and P. H. Zedler. 1978. Reproduction of chaparral shrubs after fire: a comparison of sprouting and seeding strategies. American Midland Naturalist. 99(1): 142-161.

Kelly, K. M., J. van Staden, and W. E. Bell. 1992. Seed coat structure and dormancy. Plant Growth Regulation 11:201-209.

Kozlowski, T.T. and C.E. Ahlgren. 1974. Fire and Ecosystems. New York: Academic Press.

Kummerow, J. 1982. The relation between root and shoot systems in chaparral shrubs. In: Conrad, C. Eugene; Oechel, Walter C., technical coordinators. Proceedings of the symposium on dynamics and management of Mediterranean-type ecosystems; 1981 June 22-26; San Diego, CA. Gen. Tech. Rep. PSW-58. Berkeley, CA: U.S. Department of Agriculture, Forest Service, Pacific Southwest Forest and Range Experiment Station: 142-147.

Kummerow, J., D. Krause, and W. Jow. 1977. Root systems of chaparral shrubs. Oecologia. 29: 163-177.

de Lange, J. H., and C. Boucher. 1990. Autoecological studies on Audonia capitata (Bruniaceae). I. Plant-derived smoke as a seed germination cue. South African Journal of Botany 56:188-202.

LeHouerou, H.N. 1972. Africa-the Mediterranean region, p. 26-36. In: C.M. McKell et al. (eds.), Wildland shrubs-their biology and utilization.USDA ForEST Serv.. Gen. Tech. Ren. INT-1.

McPherson, J. K. and C. H. Muller. 1969. Allelopathic effects of Adenostoma fasciculatum, "chamise", in the California chaparral. Ecological Monographs 39:177-198.

Mirov, N. T. and C.J. Kraebel, 1937. Collecting and propagating the seeds of California wild plants. Res. Note No. 18. Berkeley, CA: U.S. Department of Agriculture, Forest Service, California Forest and Range Experiment Station. 27 p.

Moreno, J.M. and W.C. Oechel. 1991. Fire intensity effects on germination of shrubs and herbs in Southern California chaparral. Ecology 72(6):1993-2004. 
Morro Group, Inc. 1995. Final program environmental impact report for the proposed Rocky Canyon Quarry. Prepared for the Dept. of Planning and Building, Environmental Division, San Luis Obispo, California.

Munz, Philip A. 1973. A California flora and supplement. Berkeley, CA: University of California Press. 1905 p.

National Academy of Science. 1974. Rehabilitation potential of western coal lands. Ballinger, Cambrige, MA.

Naveh, Z. 1973 Effect of fire in Mediterranean region. In: Fire and Ecosystems. T.T. Kozlowski and C.E. Ahlgren (Eds), Academic Press, New York; 1974; pp. 401-434.

Newton, Gail A. and V. P. Claassen. 2003. Rehabilitation of Disturbed Lands in California: A Manual for Decision Making, California Geological Survey Special Publication 123, 228 p.

Parker, V. T. 1987. Effects of wet-season management burns on chaparral vegetation: implications for rare species. Pp. 233-237 in T. S. Elias (ed.), Conservation and management of rare and endangered plants. California Native Plant Society, Sacramento.

Parker V. T. and V. R. Kelly. 1989. Seed banks in California chaparral and other Mediterranean climate shrublands. Pp. 231-255 in M. A. Leck, V. T. Parker and R. L. Simpson (eds.), Ecology of soil seed banks. Academic Press, New York.

Philpot, C.W. 1977. Vegetative features and determinants of fire frequency and intensity. In: H.A. Mooney; Conrad, C.E., eds. Symposium on the environmental consequences of fire and fuel management in Mediterranean ecosystems; Palo Alto, CA. Gen. Tech. Rep.WO3. Washington, DC: Forest Service, U.S. Department of Agriculture; 12-16.

Purdie, R. and R. Slatyer. 1976. Vegetation succession after fire in sclerophyll woodland communities in south-eastern Australia. Australian Journal of Ecology. 1: 223-236.

Reid, C. and W. Oechel. 1984. Effect of shrubland management on vegetation. In: DeVries, Johannes J., ed. Shrublands in California: literature review and research needed for management. Contribution No. 191. Davis, CA: University of California, Water Resources Center: 25-41.

Rice, S. K. 1993. Vegetation establishment in post-fire Adenostoma chaparral in relation to fine-scale pattern in fire intensity and soil nutrients. Journal of Vegetation Science 43:115-124.

Roche S., J.M Koch, and K.W. Dixon. 1997. Smoke enhanced seed germination for mine rehabilitation in the southwest of Western Australia. Restoration Ecology 5:191-203

Rundel, Philip W. 1982. Successional dynamics of chamise chaparral: the interface of basic research and management. In: Conrad, C. Eugene; Oechel, Walter C., technical coordinators. Proceedings of the symposium on dynamics and management of 
Mediterranean-type ecosystems; 1981 June 22-26; San Diego, CA. Gen. Tech. Rep. PSW-58. Berkeley, CA: U.S. Department of Agriculture, Forest Service, Pacific Southwest Forest and Range Experiment Station: 86-90.

Sampson, A. W. 1944. Plant succession on burned chaparral lands in northern California. Bull. 65. Berkeley, CA: University of California, College of Agriculture, Agricultural Experiment Station. 144 p.

Sampson, A. W. and B. S. Jespersen. 1963. California range brushlands and browse plants. Berkeley, CA: University of California, Division of Agricultural Sciences, California Agricultural Experiment Station, Extension Service. 162 p.

Santa Barbara City College Biological Sciences (no-date). Introduction to the Chaparral Retrieved September 9, 2008 from http://www.biosbcc.net/b100plant/htm/hard.htm

SMARA -California Surface Mining and Reclamation Act of 1975, California Public Resources Code (PRC)

Specht, R. L., P. Rayson, and M. E. Jackman. 1958. Dark Island Heath (Ninety Mile Plain, South Australia). V.I. Pyric succession: Changes in composition, coverage, dry weight, and mineral nutrient status. Australian Journal of Botany 6, 59-88.

State of Wyoming (no date). Construction Aggregate. Retrieved August 20, 2008 from http://www.wsgs.uwyo.edu/industrial/aggregate.aspx

Stone, Edward C.; Juhren, Gustaf. 1953. Fire stimulated germination: effect of burning on germination of brush seed investigated in physiological study of chamise. California Agriculture. 7(9): 13-14.

Sweeney. 1956. Response of Vegetation to Fire - A study of Herbaceous Vegetation Following Chaparral Fires University of California Pub Bot 28: 143-216

Teipordei, V.V., 2005, Stone (crushed): U.S. Geological Survey, Mineral Commodity Survey $2 \mathrm{p}$.

Thanos, C. A., K. Georghiou, C. Kadis, and C. Pantazi. 1992. Cistaceae: a plant family with hard seeds. Israel Journal of Botany 41:1-263.

Thanos, C.A., and P.W. Rundel. 1995. Fire-followers in chaparral: nitrogenous compounds trigger seed germination. Journal of Ecology 83:207-216.

Van Dersal, W. R. 1938. Native woody plants of the United States, their erosion-control and wildlife values. Washington, DC: U.S. Department of Agriculture. 362 p.

Vogl, R J. and P.K. Schorr. 1972. Fire and manzanita chaparral in the San Jacinto Mountains, California. Ecology. 53(6): 1179-1188. 
Wicklow, D. T. 1977. Germination response in Emmenanthe penduliflora (Hydrophyllaceae). Ecology 58:201-205.

Went, F., W. G. Juhren, and M.C. Juhren. 1952. Fire and biotic factors affecting germination. Ecology. 33(3): 351-364.

Wirtz, W O., II. 1977. Vertebrate post-fire succession. In: Mooney, Harold A.; Conrad, C. Eugene, technical coordinators. Symposium on the environmental consequences of fire and fuel management in Mediterranean ecosystems: Proceedings; 1977 August 1-5; Palo Alto, CA. Gen. Tech. Rep. WO-3. Washington, DC: U.S. Department of Agriculture, Forest Service: 46-57.

Zammit, C A., and P.H. Zedler. 1988. The influence of dominant shrubs, fire, and time since fire on soil seed banks in mixed chaparral. Vegetation. 75: 175-187.

Zedler, P. H. 1977. Life history attributes of plants and the fire cycle: a case study in chaparral dominated by Cupressus forbesii. In: Mooney, Harold A.; Conrad, C. Eugene, technical coordinators. Symposium on the environmental consequences of fire and fuel management on Mediterranean ecosystems: Proceedings; 1977 August 1-5; Palo Alto, CA. Gen. Tech. Rep. WO-3. Washington, DC: U.S. Department of Agriculture, Forest Service: $451-458$.

Zedler, P.H. 1982. Plant demography and chaparral management in southern California, p. 123-127. In: C.E. Conrad and W.C. Oechel. Proceedings of the symposium on dynamics and management of Mediterranean type ecosystems. U.S. Forest Service Gen. Tech. Rep. PSW-58. 
APPENDIX A: Number of Seeds Germinated by Plot. 
Table A-1: Germination Data 2003

\begin{tabular}{|c|c|c|c|c|}
\hline Treatment & Treatment & Plot 1 & Plot 2 & Plot 3 \\
\hline 1 & Nothing & 0 & 0 & 0 \\
\hline 2 & Just seeds & 1 & 0 & 0 \\
\hline 3 & $\mathrm{H}$ & 0 & 0 & 0 \\
\hline 4 & $\mathrm{CS}$ & 1 & 1 & 1 \\
\hline 5 & $\mathrm{CF}$ & 0 & 0 & 0 \\
\hline 6 & LSS & 93 & 107 & 69 \\
\hline 7 & LSF & 1 & 1 & 0 \\
\hline 8 & CHS & 11 & 33 & 34 \\
\hline 9 & SAS & 0 & 3 & 1 \\
\hline 10 & $\mathrm{H}, \mathrm{CS}$ & 10 & 1 & 14 \\
\hline 11 & $\mathrm{H}, \mathrm{CF}$ & 2 & 5 & 1 \\
\hline 12 & $\mathrm{H}, \mathrm{LSS}$ & 55 & 2 & 17 \\
\hline 13 & $\mathrm{H}, \mathrm{LSF}$ & 0 & 2 & 2 \\
\hline 14 & $\mathrm{H}, \mathrm{CHS}$ & 5 & 16 & 1 \\
\hline 15 & $\mathrm{H}, \mathrm{SAS}$ & 3 & 0 & 0 \\
\hline 16 & LSS, CS & 79 & 37 & 34 \\
\hline 17 & LSS, CF & 93 & 142 & 84 \\
\hline 18 & LSS, SAS & 8 & 41 & 57 \\
\hline 19 & CS, LSF & 3 & 3 & 0 \\
\hline 20 & CF, LSF & 0 & 0 & 0 \\
\hline 21 & SAS, LSF & 2 & 0 & 0 \\
\hline 22 & CHS, CS & 16 & 18 & 27 \\
\hline 23 & CHS, CF & 10 & 10 & 13 \\
\hline 24 & CHS, SAS & 39 & 35 & 21 \\
\hline 25 & CS, SAS & 13 & 9 & 9 \\
\hline 26 & SAS, CF & 0 & 3 & 2 \\
\hline 27 & $\mathrm{H}, \mathrm{LSS}, \mathrm{CS}$ & 16 & 46 & 29 \\
\hline 28 & $\mathrm{H}, \mathrm{CS}, \mathrm{LSF}$ & 8 & 19 & 0 \\
\hline 29 & $\mathrm{H}, \mathrm{CHS}, \mathrm{CS}$ & 28 & 3 & 33 \\
\hline 30 & $\mathrm{H}, \mathrm{LSS}, \mathrm{CF}$ & 19 & 25 & 42 \\
\hline 31 & $\mathrm{H}, \mathrm{CF}, \mathrm{LSF}$ & 0 & 0 & 4 \\
\hline 32 & $\mathrm{H}, \mathrm{CHS}, \mathrm{CF}$ & 4 & 1 & 9 \\
\hline 33 & LSS, CS, SAS & 45 & 87 & 61 \\
\hline 34 & CS, SAS, LSF & 4 & 4 & 0 \\
\hline 35 & CHS, CS, SAS & 32 & 32 & 22 \\
\hline 36 & LSS, SAS, CF & 76 & 54 & 63 \\
\hline 37 & SAS, CF, LSF & 0 & 0 & 1 \\
\hline 38 & CHS, SAS, CF & 27 & 23 & 23 \\
\hline 39 & $\mathrm{H}, \mathrm{CS}, \mathrm{SAS}$ & 12 & 44 & 6 \\
\hline 40 & $\mathrm{H}, \mathrm{SAS}, \mathrm{CF}$ & 4 & 0 & 6 \\
\hline 41 & H, LSS, SAS & 16 & 3 & 1 \\
\hline 42 & H, SAS, LSF & 2 & 4 & 0 \\
\hline 43 & $\mathrm{H}, \mathrm{CHS}, \mathrm{SAS}$ & 54 & 32 & 18 \\
\hline 44 & H, LSS, CS, SAS & 67 & 19 & 4 \\
\hline 45 & H, CS, SAS, LSF & 10 & 22 & 0 \\
\hline 46 & $\mathrm{H}, \mathrm{CHS}, \mathrm{CS}, \mathrm{SAS}$ & 29 & 28 & 8 \\
\hline 47 & H, LSS, SAS, CF & 64 & 128 & 36 \\
\hline 48 & H, SAS, CF, LSF & 1 & 2 & 0 \\
\hline 49 & $\mathrm{H}, \mathrm{CHS}, \mathrm{SAS}, \mathrm{CF}$ & 11 & 5 & 0 \\
\hline
\end{tabular}

\section{Legend}

$\mathrm{H}=$ Heat

$\mathrm{CS}=$ Charate Soak

$\mathrm{CF}=$ Charate Field

LSS=Liquid Smoke Soak

LSF=Liquid Smoke Field

CHS=Chamise Smoke

$\mathrm{SAS}=$ Sulfuric Acid Soak 
Table A-2: Germination Data 2004

\begin{tabular}{|c|c|c|c|c|}
\hline Treatment & Treatment & Plot 1 & Plot 2 & Plot 3 \\
\hline 1 & Nothing & 0 & 0 & 0 \\
\hline 2 & Just seeds & 85 & 2 & 11 \\
\hline 3 & $\mathrm{H}$ & 31 & 3 & 9 \\
\hline 4 & $\mathrm{CS}$ & 99 & 102 & 49 \\
\hline 5 & $\mathrm{CF}$ & 9 & 9 & 64 \\
\hline 6 & LSS & 180 & 258 & 187 \\
\hline 7 & LSF & 19 & 20 & 364 \\
\hline 8 & CHS & 453 & 221 & 342 \\
\hline 9 & SAS & 0 & 0 & 69 \\
\hline 10 & $\mathrm{H}, \mathrm{CS}$ & 64 & 74 & 90 \\
\hline 11 & $\mathrm{H}, \mathrm{CF}$ & 60 & 51 & 52 \\
\hline 12 & $\mathrm{H}, \mathrm{LSS}$ & 271 & 172 & 313 \\
\hline 13 & $\mathrm{H}, \mathrm{LSF}$ & 193 & 11 & 20 \\
\hline 14 & $\mathrm{H}, \mathrm{CHS}$ & 204 & 142 & 249 \\
\hline 15 & $\mathrm{H}, \mathrm{SAS}$ & 9 & 8 & 4 \\
\hline 16 & LSS, CS & 181 & 219 & 221 \\
\hline 17 & LSS, CF & 212 & 184 & 221 \\
\hline 18 & LSS, SAS & 337 & 112 & 221 \\
\hline 19 & $\mathrm{CS}, \mathrm{LSF}$ & 148 & 117 & 124 \\
\hline 20 & CF, LSF & 62 & 206 & 56 \\
\hline 21 & SAS, LSF & 165 & 75 & 128 \\
\hline 22 & CHS, CS & 324 & 367 & 279 \\
\hline 23 & CHS, CF & 285 & 272 & 310 \\
\hline 24 & CHS, SAS & 295 & 388 & 347 \\
\hline 25 & $\mathrm{CS}, \mathrm{SAS}$ & 184 & 146 & 226 \\
\hline 26 & SAS, CF & 12 & 51 & 12 \\
\hline 27 & H, LSS, CS & 163 & 197 & 229 \\
\hline 28 & $\mathrm{H}, \mathrm{CS}, \mathrm{LSF}$ & 69 & 151 & 87 \\
\hline 29 & $\mathrm{H}, \mathrm{CHS}, \mathrm{CS}$ & 198 & 124 & 222 \\
\hline 30 & $\mathrm{H}, \mathrm{LSS}, \mathrm{CF}$ & 228 & 312 & 155 \\
\hline 31 & $\mathrm{H}, \mathrm{CF}, \mathrm{LSF}$ & 54 & 154 & 102 \\
\hline 32 & $\mathrm{H}, \mathrm{CHS}, \mathrm{CF}$ & 202 & 228 & 341 \\
\hline 33 & LSS, CS, SAS & 285 & 209 & 320 \\
\hline 34 & CS, SAS, LSF & 168 & 141 & 187 \\
\hline 35 & CHS, CS, SAS & 297 & 323 & 317 \\
\hline 36 & LSS, SAS, CF & 263 & 250 & 269 \\
\hline 37 & SAS, CF, LSF & 258 & 116 & 118 \\
\hline 38 & CHS, SAS, CF & 354 & 376 & 316 \\
\hline 39 & $\mathrm{H}, \mathrm{CS}, \mathrm{SAS}$ & 166 & 248 & 200 \\
\hline 40 & $\mathrm{H}, \mathrm{SAS}, \mathrm{CF}$ & 169 & 81 & 27 \\
\hline 41 & H, LSS, SAS & 223 & 242 & 186 \\
\hline 42 & H, SAS, LSF & 173 & 208 & 156 \\
\hline 43 & $\mathrm{H}, \mathrm{CHS}, \mathrm{SAS}$ & 343 & 270 & 180 \\
\hline 44 & H, LSS, CS, SAS & 255 & 263 & 274 \\
\hline 45 & $\mathrm{H}, \mathrm{CS}, \mathrm{SAS}, \mathrm{LSF}$ & 208 & 258 & 176 \\
\hline 46 & $\mathrm{H}, \mathrm{CHS}, \mathrm{CS}, \mathrm{SAS}$ & 328 & 370 & 273 \\
\hline 47 & H, LSS, SAS, CF & 245 & 233 & 216 \\
\hline 48 & H, SAS, CF, LSF & 37 & 87 & 77 \\
\hline 49 & $\mathrm{H}, \mathrm{CHS}, \mathrm{SAS}, \mathrm{CF}$ & 284 & 259 & 298 \\
\hline
\end{tabular}

\section{Legend}

$\mathrm{H}=$ Heat

$\mathrm{CS}=$ Charate Soak

$\mathrm{CF}=$ Charate Field

LSS=Liquid Smoke Soak

LSF=Liquid Smoke Field

CHS=Chamise Smoke

$\mathrm{SAS}=$ Sulfuric Acid Soak 
APPENDIX B: Statistical Analyses: Minitab Output 
Minitab Results of One-way Analysis of Variance on 2002-2003 Data Set

$\begin{array}{lrrrrr}\text { Source } & \text { DF } & \text { SS } & \text { MS } & \text { F } & \text { P } \\ \text { Stacked treatments } & 47 & 1037.08 & 22.07 & 11.16 & 0.000 \\ \text { Error } & 96 & 189.85 & 1.98 & & \\ \text { Total } & 143 & 1226.93 & & & \end{array}$

$\mathrm{S}=1.406 \quad \mathrm{R}-\mathrm{Sq}=84.53 \% \mathrm{R}-\mathrm{Sq}(\operatorname{adj})=76.95 \%$

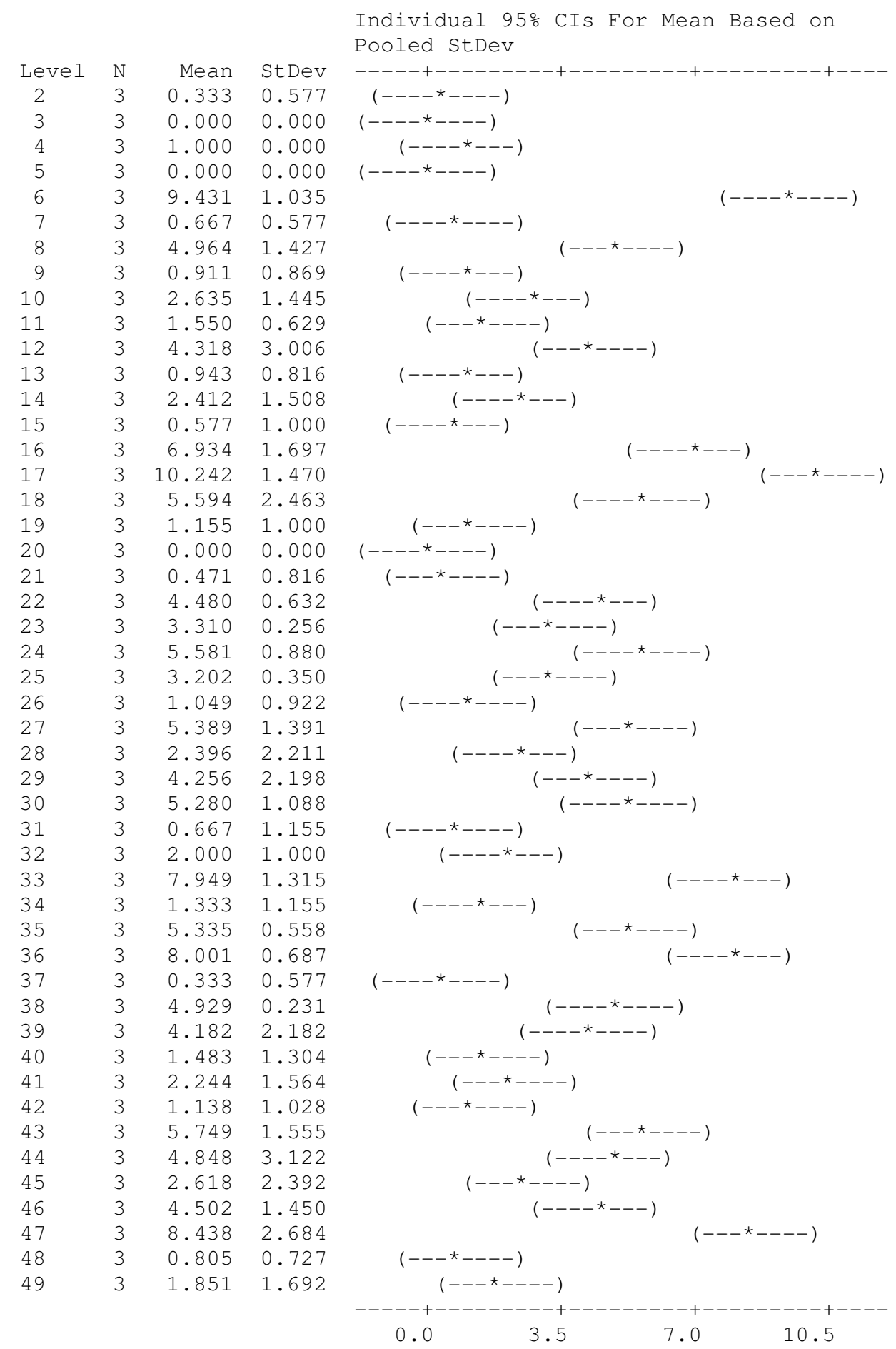

Pooled StDev $=1.406$ 


\section{Minitab Results for Hsu's MCB (Multiple Comparisons with the Best) on 2002-2003 Data Set}

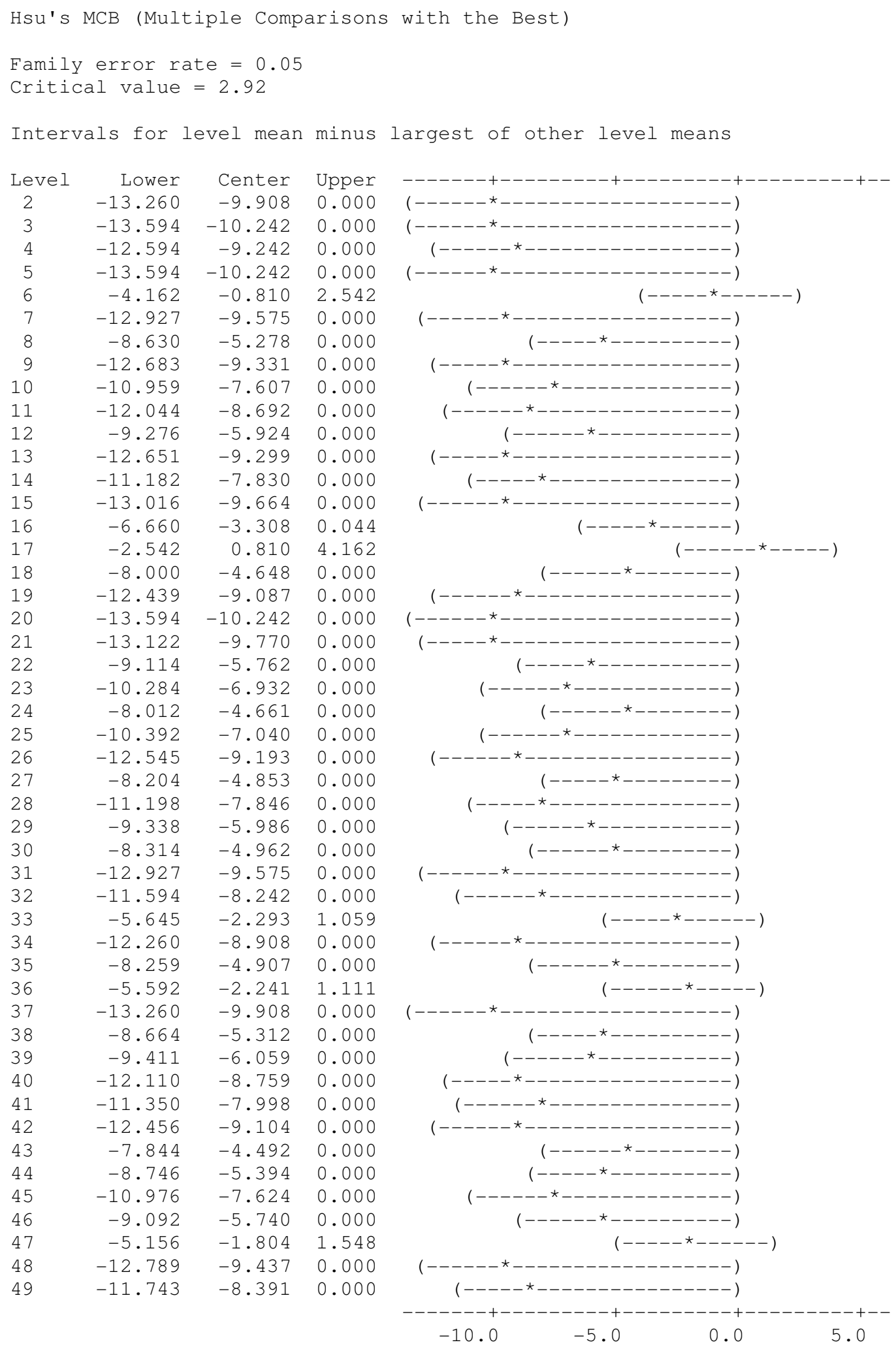


Minitab Results of One-way Analysis of Variance on 2002-2003 data that was found to be the best and those that were insignificantly different from the best.

$\begin{array}{lrrrrr}\text { Source } & \text { DF } & \text { SS } & \text { MS } & \text { F } & \text { P } \\ \text { Stacked treatments } & 4 & 11.91 & 2.98 & 1.18 & 0.377 \\ \text { Error } & 10 & 25.27 & 2.53 & & \\ \text { Total } & 14 & 37.18 & & & \\ & \\ \text { S }=1.590 \quad \text { R-Sq }=32.04 \% & \text { R-Sq }(\text { adj })=4.85 \%\end{array}$

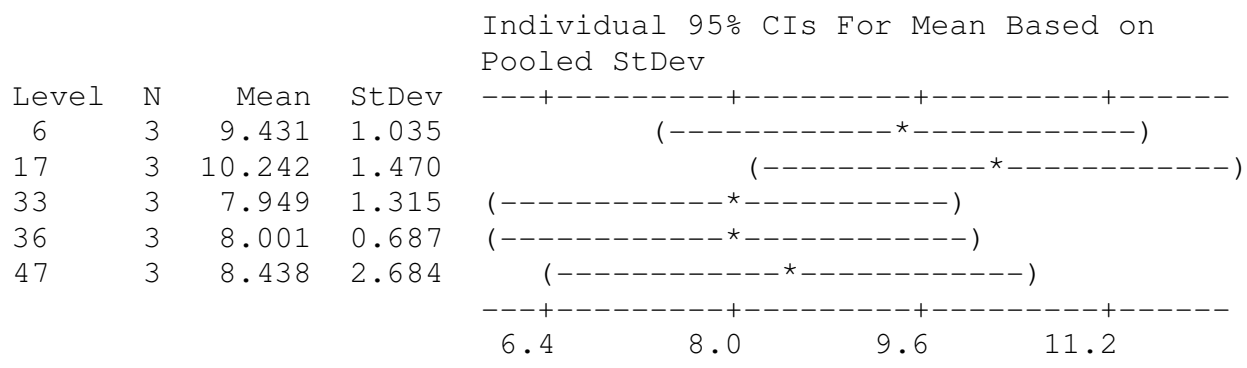

Pooled StDev $=1.590$

Minitab Results of Hsu's MCB (Multiple Comparisons with the Best) on 2002-2003 data that was found to be the best and those that were insignificantly different from the best.

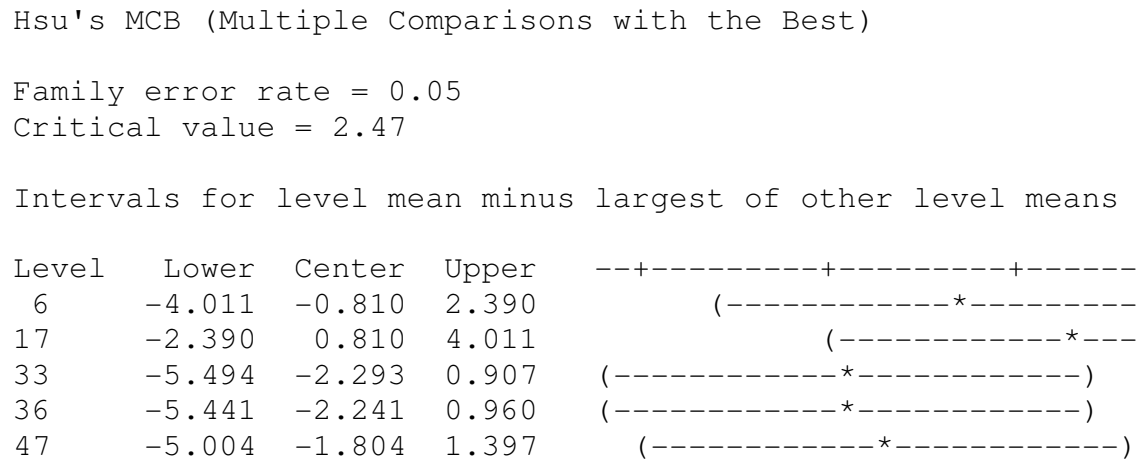




\section{Minitab Results of One-way Analysis of Variance on the 2003-2004 Data Set}

$\begin{array}{lrrrrr}\text { Source } & \text { DF } & \text { SS } & \text { MS } & \text { F } & \text { P } \\ \text { Stacked treatments } & 47 & 2885.06 & 61.38 & 9.68 & 0.000 \\ \text { Error } & 96 & 608.70 & 6.34 & & \\ \text { Total } & 143 & 3493.76 & & \\ \text { S }=2.518 \quad R-S q=82.58 \% & R-S q(\text { adj })=74.05 \%\end{array}$

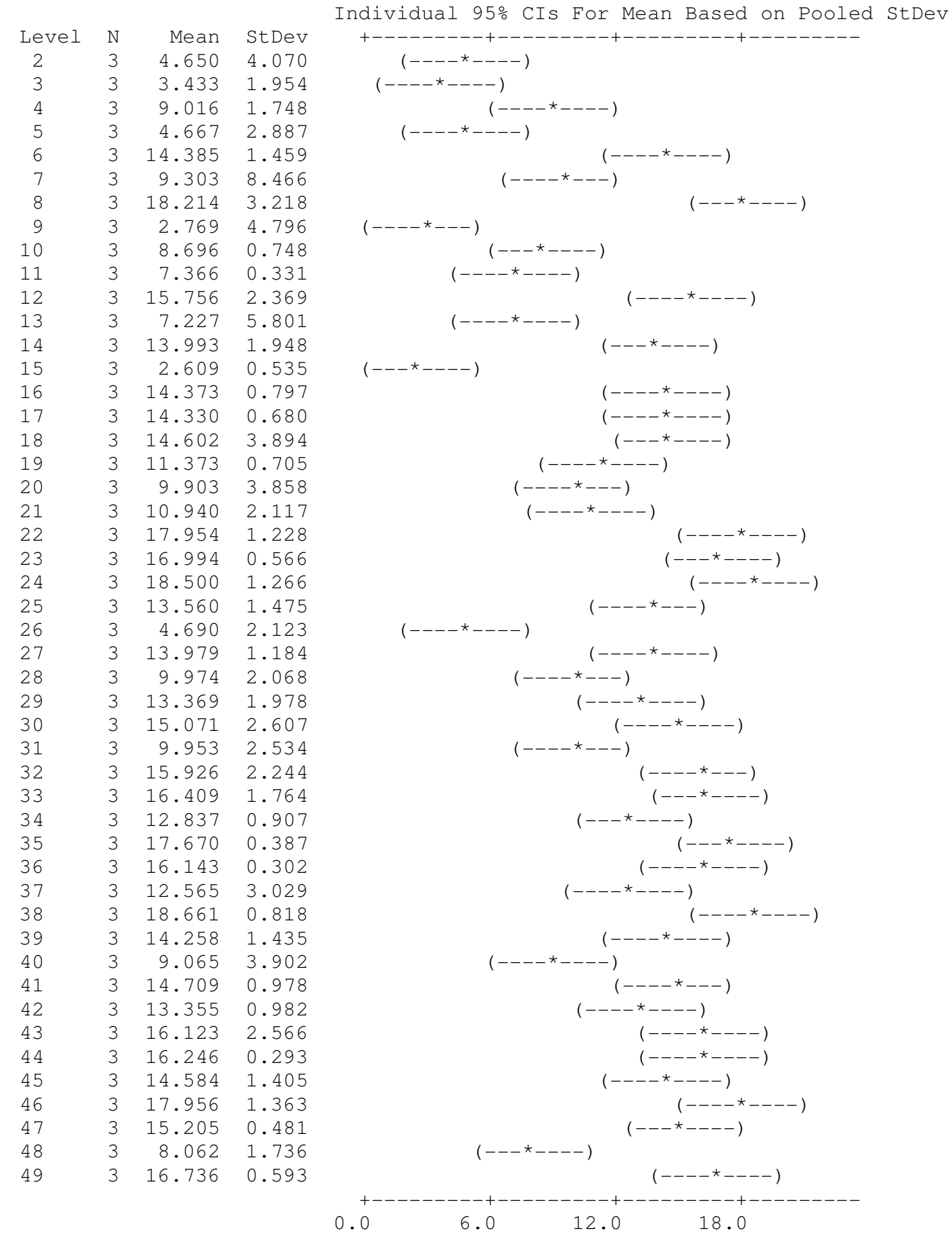

Pooled StDev $=2.518$ 


\section{Minitab Results for Hsu's MCB (Multiple Comparisons with the Best) on 2003-2004 Data Set}

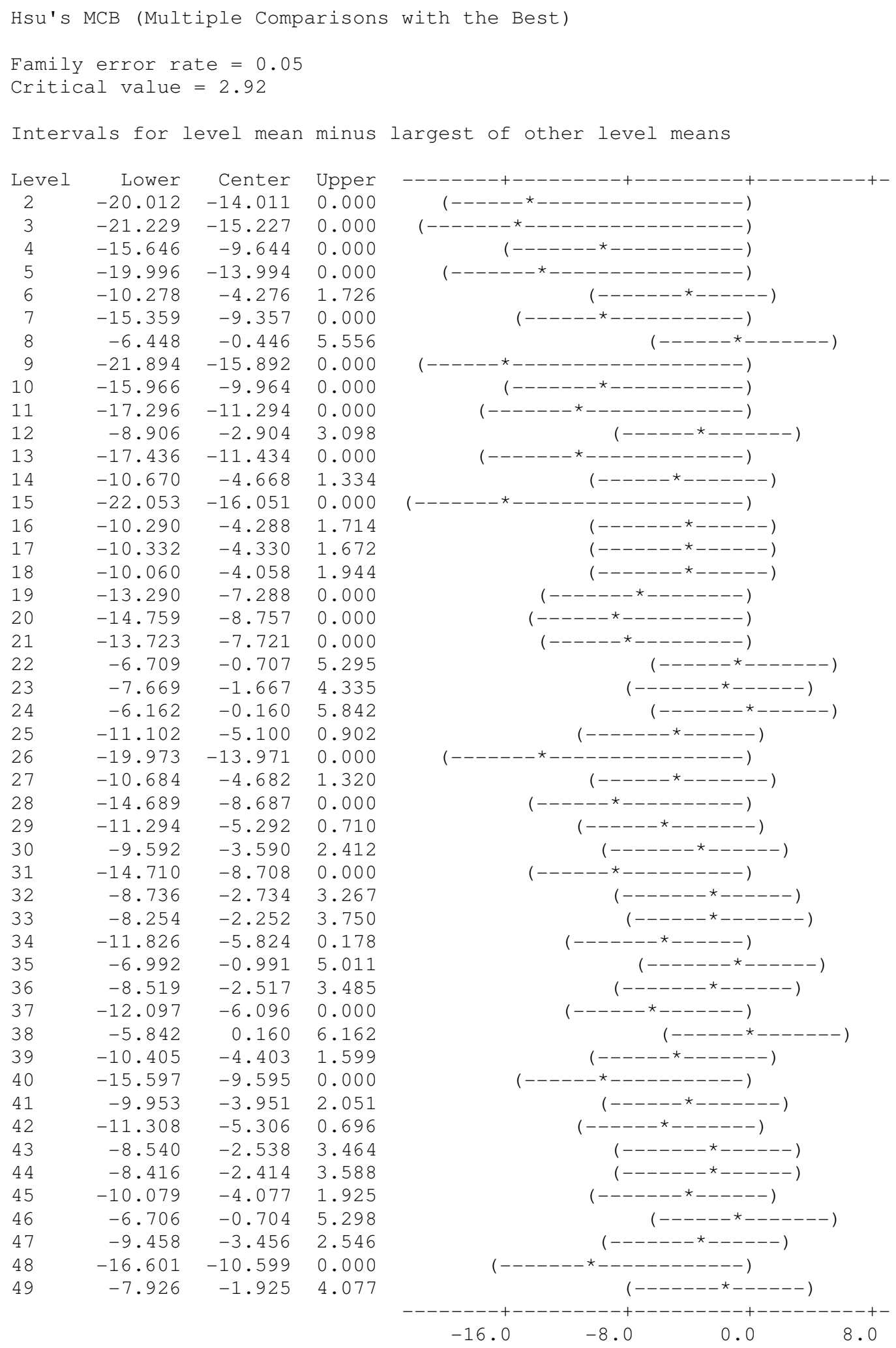


Minitab Results of One-way Analysis of Variance on 2003-2004 data that was found to be the best and those that were insignificantly different from the best.

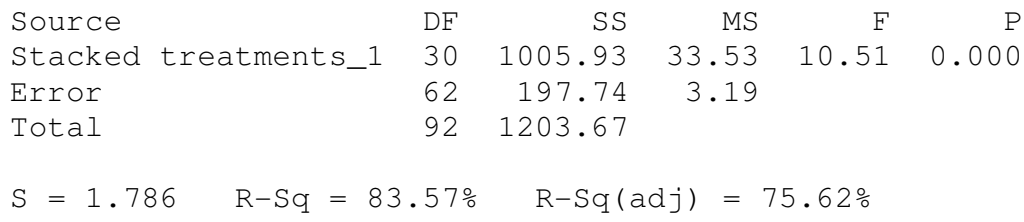

$\begin{array}{rrrr}\text { Level } & \text { N } & \text { Mean } & \text { StDev } \\ 6 & 3 & 14.385 & 1.459 \\ 8 & 3 & 18.214 & 3.218 \\ 9 & 3 & 2.769 & 4.796 \\ 10 & 3 & 8.696 & 0.748 \\ 11 & 3 & 7.366 & 0.331 \\ 14 & 3 & 13.993 & 1.948 \\ 16 & 3 & 14.373 & 0.797 \\ 17 & 3 & 14.330 & 0.680 \\ 18 & 3 & 14.602 & 3.894 \\ 22 & 3 & 17.954 & 1.228 \\ 23 & 3 & 16.994 & 0.566 \\ 24 & 3 & 18.500 & 1.266 \\ 25 & 3 & 13.560 & 1.475 \\ 27 & 3 & 13.979 & 1.184 \\ 29 & 3 & 13.369 & 1.978 \\ 30 & 3 & 15.071 & 2.607 \\ 32 & 3 & 15.926 & 2.244 \\ 33 & 3 & 16.409 & 1.764 \\ 34 & 3 & 12.837 & 0.907 \\ 35 & 3 & 17.670 & 0.387 \\ 36 & 3 & 16.143 & 0.302 \\ 38 & 3 & 18.661 & 0.818 \\ 39 & 3 & 14.258 & 1.435 \\ 41 & 3 & 14.709 & 0.978 \\ 42 & 3 & 13.355 & 0.982 \\ 43 & 3 & 16.123 & 2.566 \\ 44 & 3 & 16.246 & 0.293 \\ 45 & 3 & 14.584 & 1.405 \\ 46 & 3 & 17.956 & 1.363 \\ 47 & 3 & 15.205 & 0.481 \\ 49 & 3 & 16.736 & 0.593\end{array}$

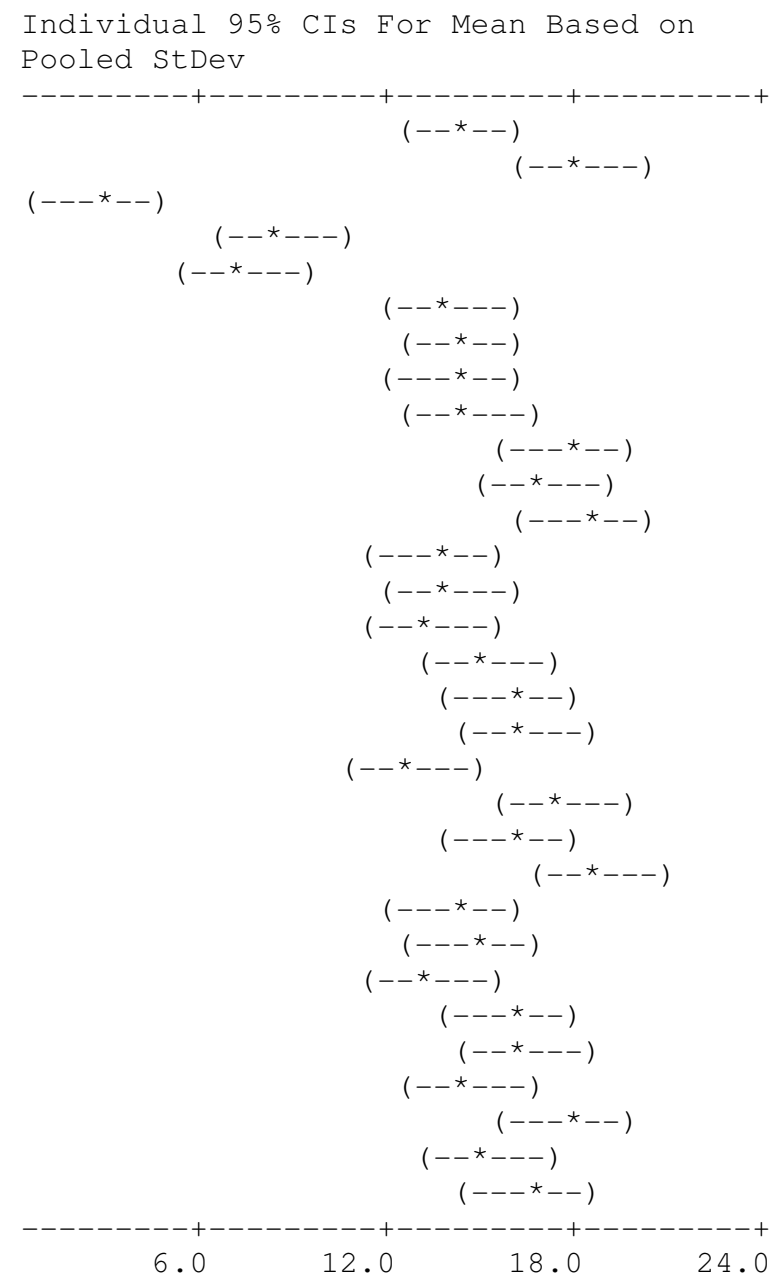

Pooled StDev $=1.786$ 


\section{Minitab Results of Hsu's MCB (Multiple Comparisons with the Best) on 2003-2004 data that was found to be the best and those that were insignificantly different from the best.}

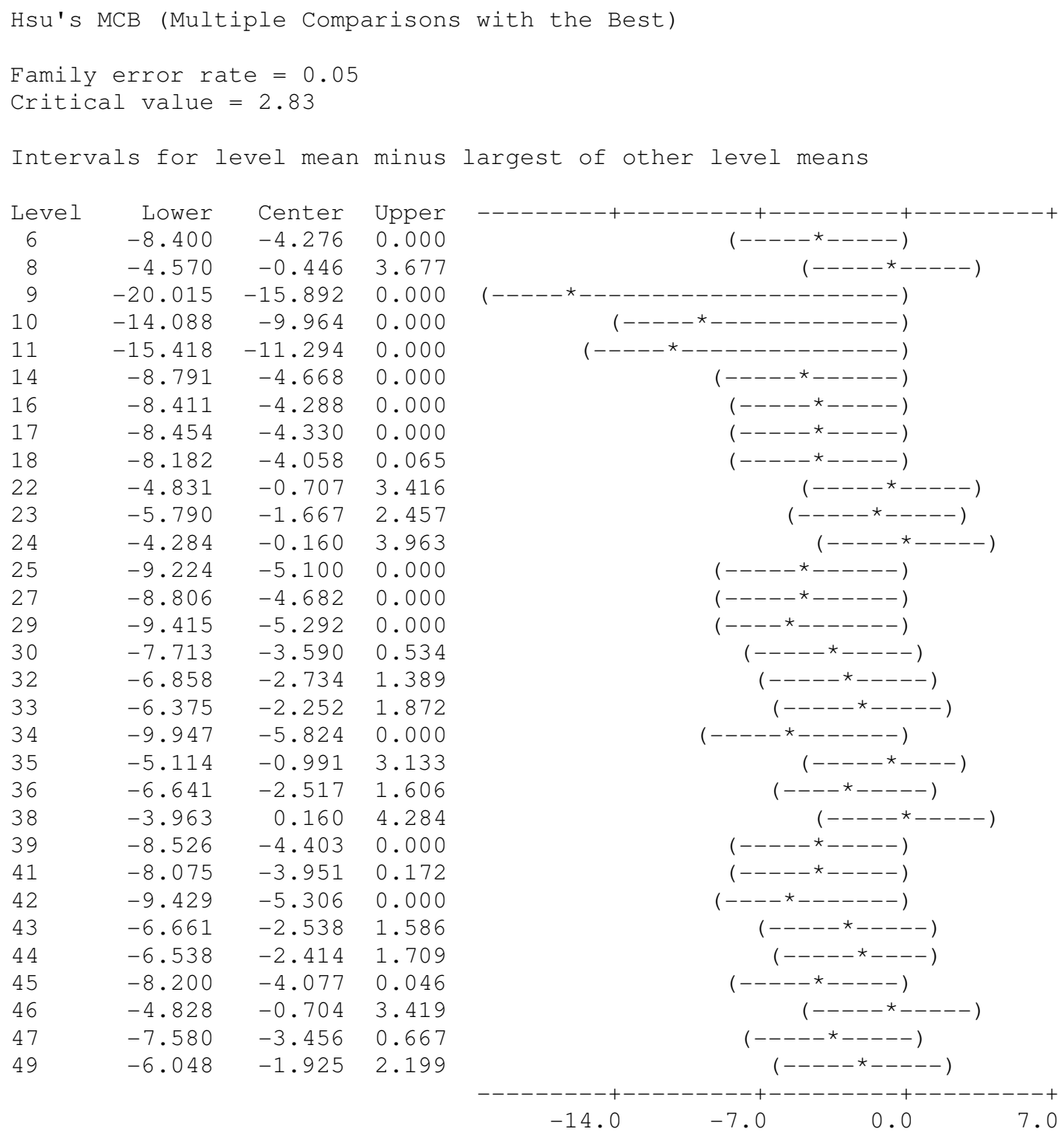




\section{Minitab Results of General Linear Model and Tukey's HSD test on the 2002-2003 Data}

$\begin{array}{llrl}\text { Factor } & \text { Type } & \text { Levels } & \text { Values } \\ \text { Heat } & \text { fixed } & 2 & 0,1 \\ \text { Charate Soak } & \text { fixed } & 2 & 0,1 \\ \text { Charate Field } & \text { fixed } & 2 & 0,1 \\ \text { Liquid Smoke Soak } & \text { fixed } & 2 & 0,1 \\ \text { Liquid Smoke Field } & \text { fixed } & 2 & 0,1 \\ \text { Chamise Smoke } & \text { fixed } & 2 & 0,1 \\ \text { Sulfuric Acid Soak } & \text { fixed } & 2 & 0,1\end{array}$

Analysis of Variance for 03 Data Squ, using Adjusted SS for Tests

Source

Heat

Charate Soak

Charate Field

Liquid Smoke Soak

Liquid Smoke Field

Chamise Smoke

Sulfuric Acid Soak

Heat*Charate Soak

Heat*Charate Field

Heat* Liquid Smoke Soak

Heat*Liquid Smoke Field

Heat*Chamise Smoke

Heat*Sulfuric Acid Soak

Charate Soak*Liquid Smoke Soak

Charate Soak*Liquid Smoke Field

Charate Soak*Chamise Smoke

Charate Soak*Sulfuric Acid Soak

Charate Field*Liquid Smoke Soak

Charate Field*Liquid Smoke Field

Charate Field*Chamise Smoke

Charate Field*Sulfuric Acid Soak

Liquid Smoke Soak*Sulfuric Acid Soak

Liquid Smoke Field*

Sulfuric Acid Soak

Chamise Smoke*Sulfuric Acid Soak

Error

Total

Source

83

Heat

Charate Soak

Charate Field

Liquid Smoke Soak

Liquid Smoke Field

Chamise Smoke

Sulfuric Acid Soak

Heat*Charate Soak

Heat*Charate Field

Heat*Liquid Smoke Soak

Heat*Liquid Smoke Field

Heat*Chamise Smoke

Heat*Sulfuric Acid Soak

Charate Soak*Liquid Smoke Soak

Charate Soak*Liquid Smoke Field

Charate Soak*Chamise Smoke

Charate Soak*Sulfuric Acid Soak

Charate Field*Liquid Smoke Soak

$\begin{array}{rrrrr}\text { DF } & \text { Seq SS } & \text { AdjSS } & \text { Adj MS } & F \\ 1 & 17.901 & 24.715 & 24.715 & 11.43 \\ 1 & 26.706 & 26.706 & 26.706 & 3.77 \\ 1 & 1.99 & 1.99 & 1.99 & 0.20 \\ 1 & 476.56 & 476.56 & 476.56 & 119.73 \\ 1 & 2.417 & 2.417 & 2.417 & 1.29 \\ 1 & 131.599 & 131.599 & 131.599 & 54.93 \\ 1 & 4.799 & 0.003 & 0.003 & 0.00 \\ 1 & 9.393 & 9.393 & 9.393 & 1.33 \\ 1 & 2.142 & 2.142 & 2.142 & 0.22 \\ 1 & 58.14 & 58.141 & 58.141 & 14.61 \\ 1 & 0.057 & 0.057 & 0.057 & 0.03 \\ 1 & 17.293 & 17.293 & 17.293 & 7.22 \\ 1 & 2.02 & 2.02 & 2.02 & 0.20 \\ 1 & 6.017 & 6.017 & 6.017 & 1.29 \\ 1 & 4.529 & 4.529 & 4.529 & 2.75 \\ 1 & 16.329 & 16.329 & 16.329 & 8.04 \\ 1 & 3.993 & 3.993 & 3.993 & 0.55 \\ 1 & 12.341 & 12.341 & 12.341 & 2.78 \\ 1 & 2.532 & 2.532 & 2.532 & 4.01 \\ 1 & 14.775 & 14.775 & 14.775 & 8.24 \\ 1 & 2.021 & 2.021 & 2.021 & 0.94 \\ 1 & 13.537 & 13.537 & 13.537 & 2.72 \\ 1 & 3.143 & 3.143 & 3.143 & 1.68 \\ & & & & \\ 1 & 0.051 & 0.051 & 0.051 & 0.02 \\ 119 & 257.206 & 257.206 & 2.161 & \\ 143 & 1226.930 & & & \\ & & & & \end{array}$

0.001

0.055

0.658

0.000

0.259

0.000

0.972

0.253

0.321

0.000

0.862

0.009

0.454

0.263

0.104

0.007

0.460

0.018 


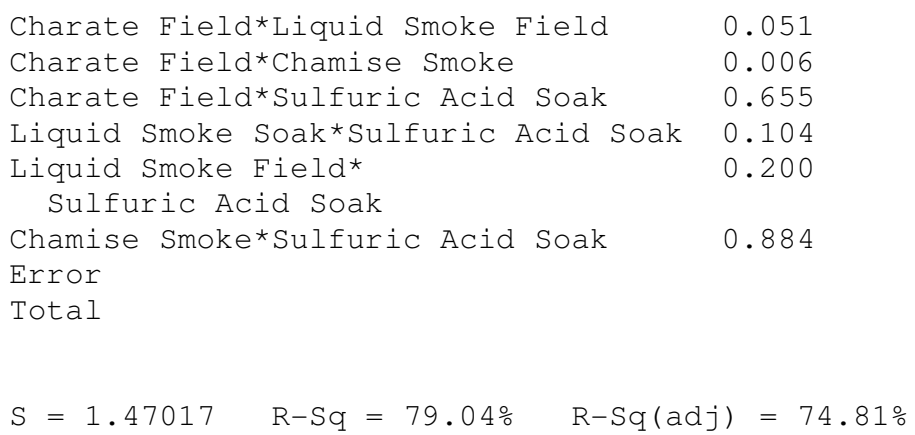

Source

1 Heat

Charate Soak

Charate Field

Liquid Smoke Soak

Liquid Smoke Field

Chamise Smoke

Sulfuric Acid Soak

Heat*Charate Soak

Heat*Charate Field

Heat*Liquid Smoke Soak

Heat*Liquid Smoke Field

Heat*Chamise Smoke

Heat*Sulfuric Acid Soak

Charate Soak*Liquid Smoke Soak

Charate Soak*Liquid Smoke Field

Charate Soak*Chamise Smoke

Charate Soak*Sulfuric Acid Soak

Charate Field*Liquid Smoke Soak

Charate Field*Liquid Smoke Field

Charate Field*Chamise Smoke

Charate Field*Sulfuric Acid Soak

Liquid Smoke Soak*Sulfuric Acid Soak

Liquid Smoke Field*

Sulfuric Acid Soak

24 Chamise Smoke*Sulfuric Acid Soak

25 Error

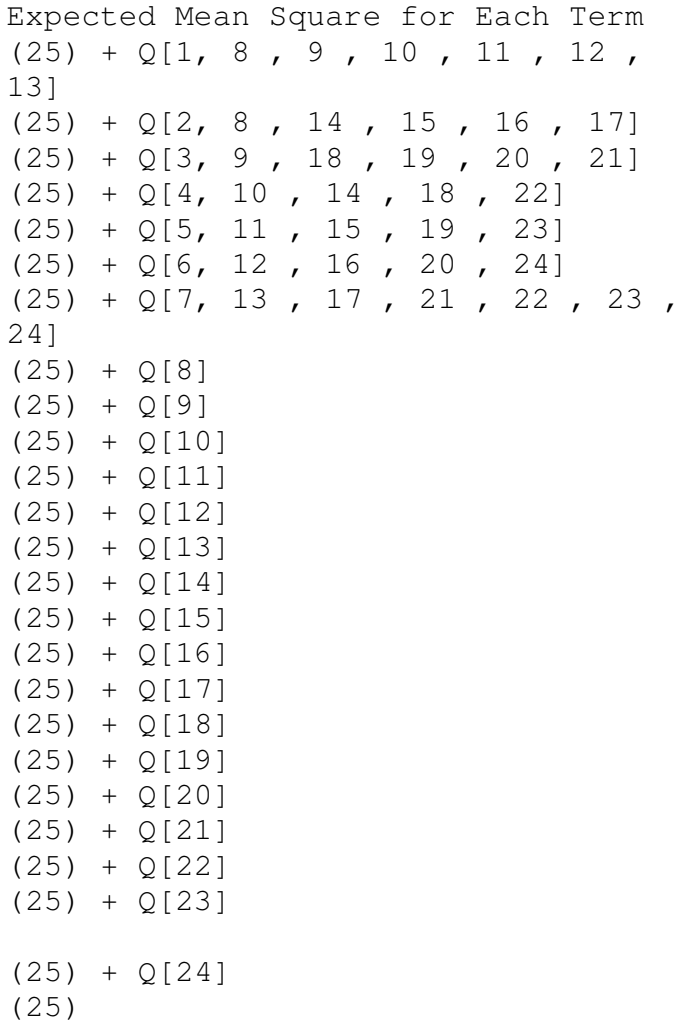


Error Terms for Tests, using Adjusted SS

\begin{tabular}{|c|c|c|c|c|}
\hline & Source & Error DF & Error MS & $\begin{array}{l}\text { Synthesis } \\
\text { of Error MS }\end{array}$ \\
\hline 1 & Heat & 119.00 & 2.161 & $(25)$ \\
\hline 2 & Charate Soak & 119.00 & 2.161 & $(25)$ \\
\hline 3 & Charate Field & 119.00 & 2.161 & $(25)$ \\
\hline 4 & Liquid Smoke Soak & 119.00 & 2.161 & $(25)$ \\
\hline 5 & Liquid Smoke Field & 119.00 & 2.161 & $(25)$ \\
\hline 6 & Chamise Smoke & 119.00 & 2.161 & $(25)$ \\
\hline 7 & Sulfuric Acid Soak & 119.00 & 2.161 & $(25)$ \\
\hline 8 & Heat*Charate Soak & 119.00 & 2.161 & $(25)$ \\
\hline 9 & Heat*Charate Field & 119.00 & 2.161 & $(25)$ \\
\hline 10 & Heat*Liquid Smoke Soak & 119.00 & 2.161 & $(25)$ \\
\hline 11 & Heat*Liquid Smoke Field & 119.00 & 2.161 & $(25)$ \\
\hline 12 & Heat*Chamise Smoke & 119.00 & 2.161 & $(25)$ \\
\hline 13 & Heat*Sulfuric Acid Soak & 119.00 & 2.161 & $(25)$ \\
\hline 14 & Charate Soak*Liquid Smoke Soak & 119.00 & 2.161 & $(25)$ \\
\hline 15 & Charate Soak*Liquid Smoke Field & 119.00 & 2.161 & $(25)$ \\
\hline 16 & Charate Soak*Chamise Smoke & 119.00 & 2.161 & $(25)$ \\
\hline 17 & Charate Soak*Sulfuric Acid Soak & 119.00 & 2.161 & $(25)$ \\
\hline 18 & Charate Field*Liquid Smoke Soak & 119.00 & 2.161 & $(25)$ \\
\hline 19 & Charate Field*Liquid Smoke Field & 119.00 & 2.161 & $(25)$ \\
\hline 20 & Charate Field*Chamise Smoke & 119.00 & 2.161 & $(25)$ \\
\hline 21 & Charate Field*Sulfuric Acid Soak & 119.00 & 2.161 & $(25)$ \\
\hline 22 & Liquid Smoke Soak*Sulfuric Acid Soak & 119.00 & 2.161 & $(25)$ \\
\hline 23 & $\begin{array}{l}\text { Liquid Smoke Field* } \\
\text { Sulfuric Acid Soak }\end{array}$ & 119.00 & 2.161 & $(25)$ \\
\hline 24 & Chamise Smoke*Sulfuric Acid Soak & 119.00 & 2.161 & $(25)$ \\
\hline
\end{tabular}

\footnotetext{
Variance Components, using Adjusted SS

$\begin{array}{lr} & \text { Estimated } \\ \text { Source } & \text { Value } \\ \text { Error } & 2.161\end{array}$
}

Tukey 95.0\% Simultaneous Confidence Intervals Response Variable 03 Data Squ

All Pairwise Comparisons among Levels of Heat*Charate Soak Heat $=0$

Charate Soak $=0$ subtracted from:

$\begin{array}{llrrr} & \text { Charate } & & \\ \text { Heat } & \text { Soak } & \text { Lower } & \text { Center } & \text { Upper } \\ 0 & 1 & -1.581 & 0.429 & 2.4398 \\ 1 & 0 & -3.332 & -1.321 & 0.6891 \\ 1 & 1 & -1.651 & 0.359 & 2.3696\end{array}$

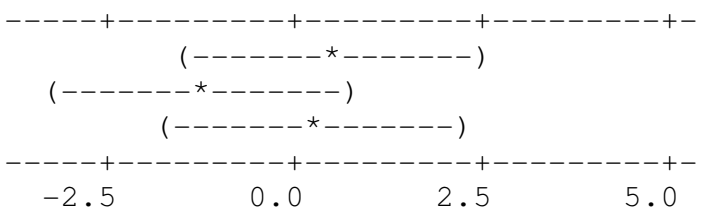

Heat $=0$

Charate $\mathrm{Soak}=1$ subtracted from:

\begin{tabular}{|c|c|c|c|c|c|}
\hline Hea & $\begin{array}{l}\text { Charate } \\
\text { Soak }\end{array}$ & Lower & Center & Upper & -+- \\
\hline 1 & 0 & -3.761 & -1.751 & 0.2599 & $\left(-------\star_{-}-------\right)$ \\
\hline 1 & 1 & -2.081 & -0.070 & 1.9403 & $(-------\star-------)$ \\
\hline
\end{tabular}




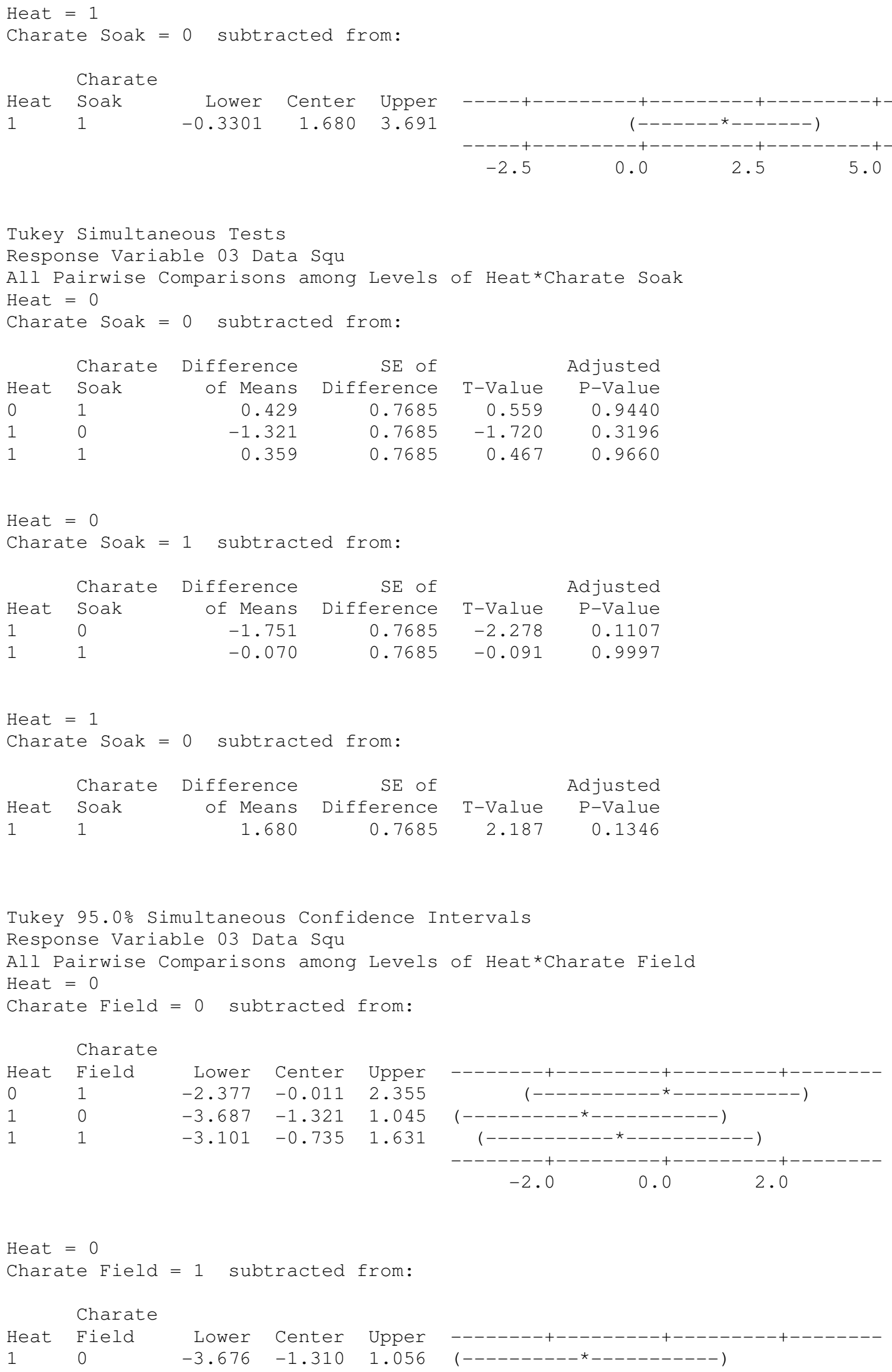




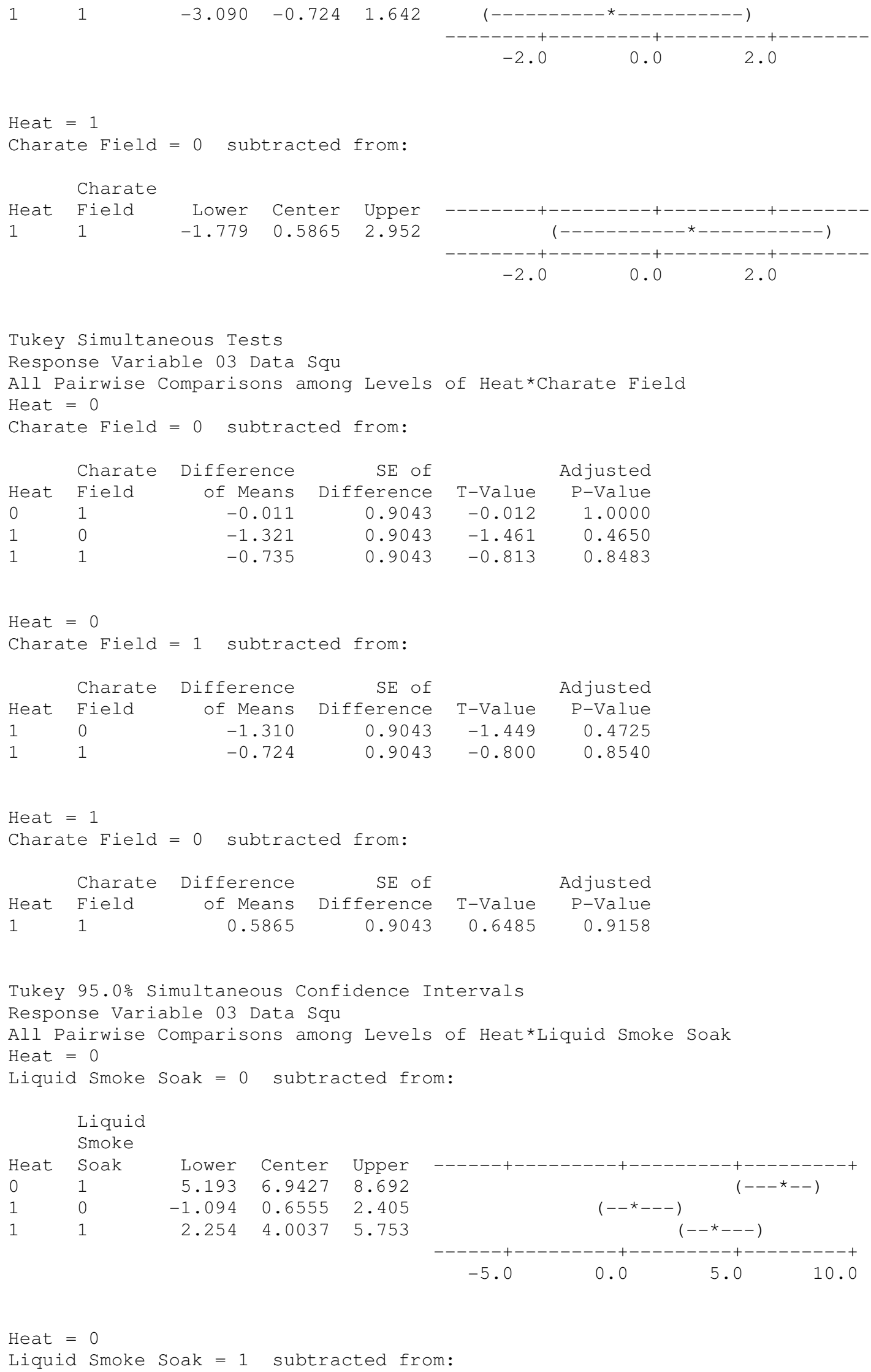




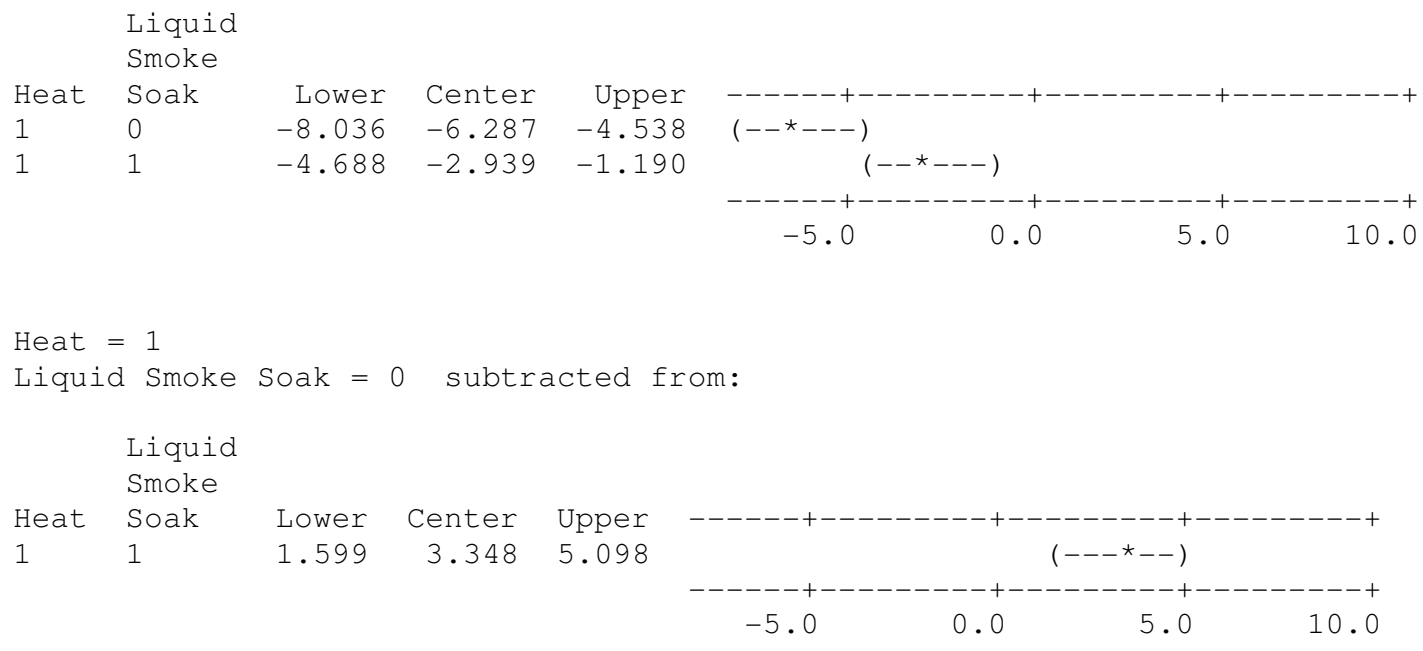

Tukey Simultaneous Tests

Response Variable 03 Data Squ

All Pairwise Comparisons among Levels of Heat*Liquid Smoke Soak Heat $=0$

Liquid Smoke Soak $=0$ subtracted from:

$\begin{array}{llrrrr} & \begin{array}{l}\text { Liquid } \\ \text { Smoke }\end{array} & \text { Difference } & \text { SE of } & & \text { Adjusted } \\ \text { Heat } & \text { Soak } & \text { Of Means } & \text { Difference } & \text { T-Value } & \text { P-Value } \\ 0 & 1 & 6.9427 & 0.6650 & 10.4398 & 0.0000 \\ 1 & 0 & 0.6555 & 0.6650 & 0.9857 & 0.7581 \\ 1 & 1 & 4.0037 & 0.6650 & 6.0205 & 0.0000\end{array}$

Heat $=0$

Liquid Smoke Soak $=1$ subtracted from:

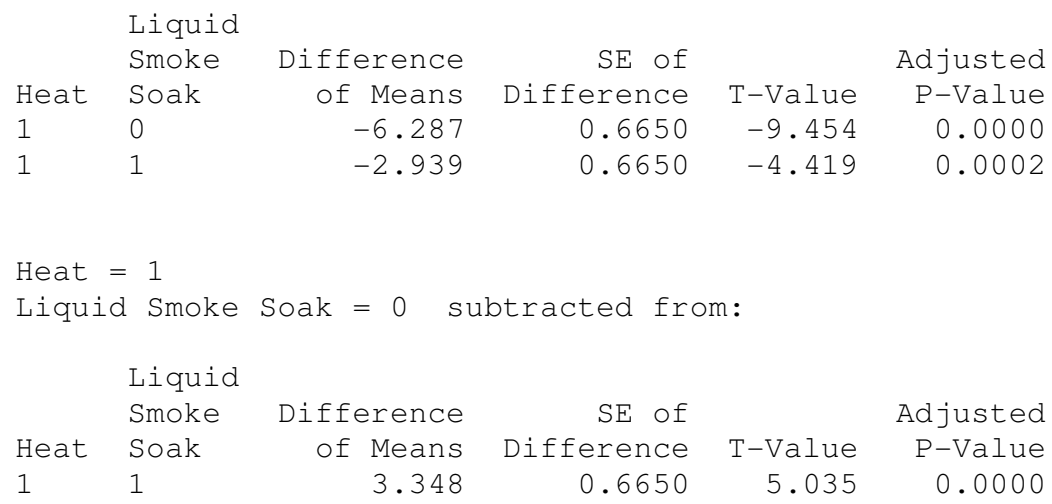

Tukey 95.0\% Simultaneous Confidence Intervals Response Variable 03 Data Squ

All Pairwise Comparisons among Levels of Heat*Liquid Smoke Field Heat $=0$

Liquid Smoke Field $=0$ subtracted from:

$\begin{array}{ll} & \text { Liquid } \\ \text { Smoke } & \\ \text { Heat Field Lower Center Upper }\end{array}$




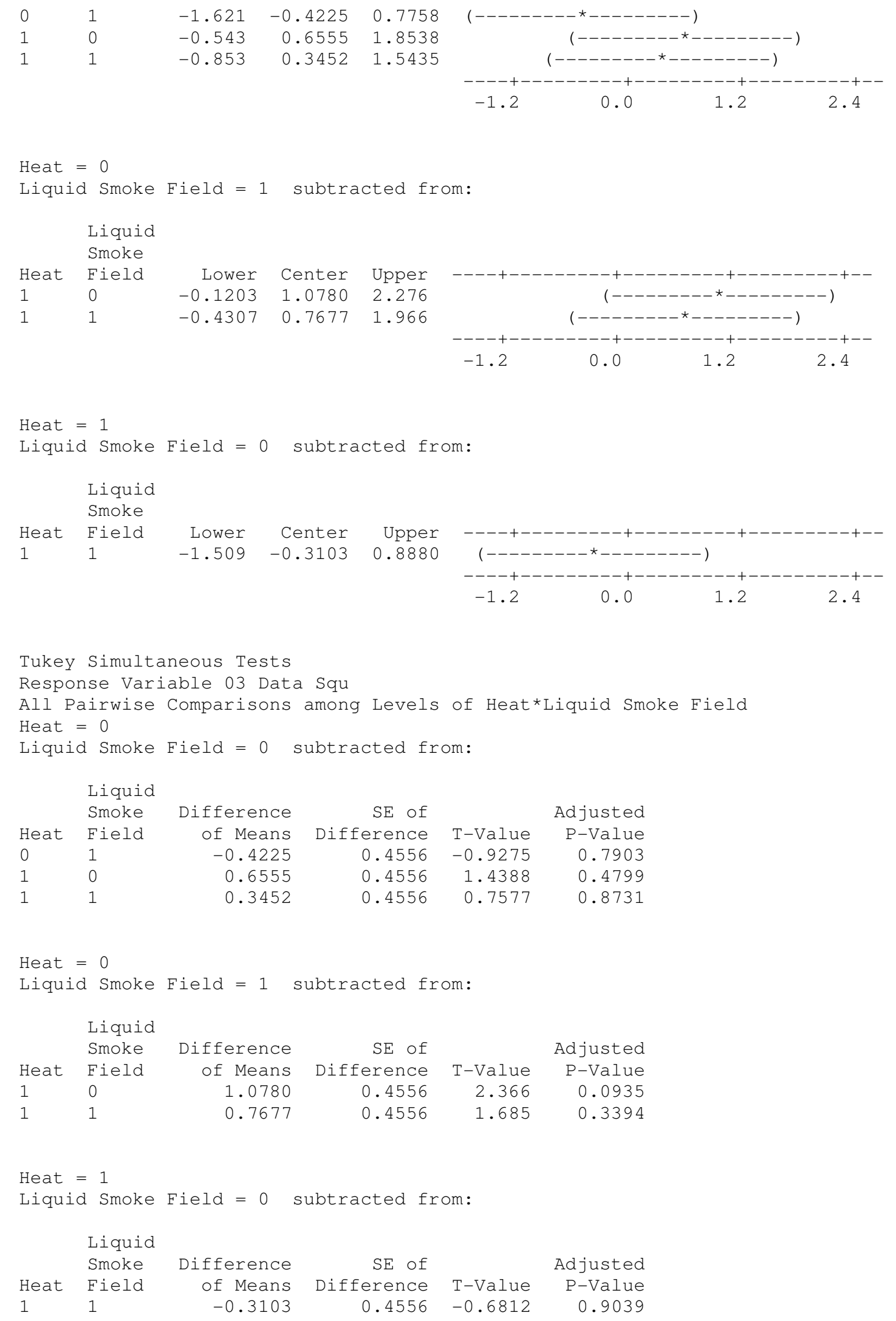




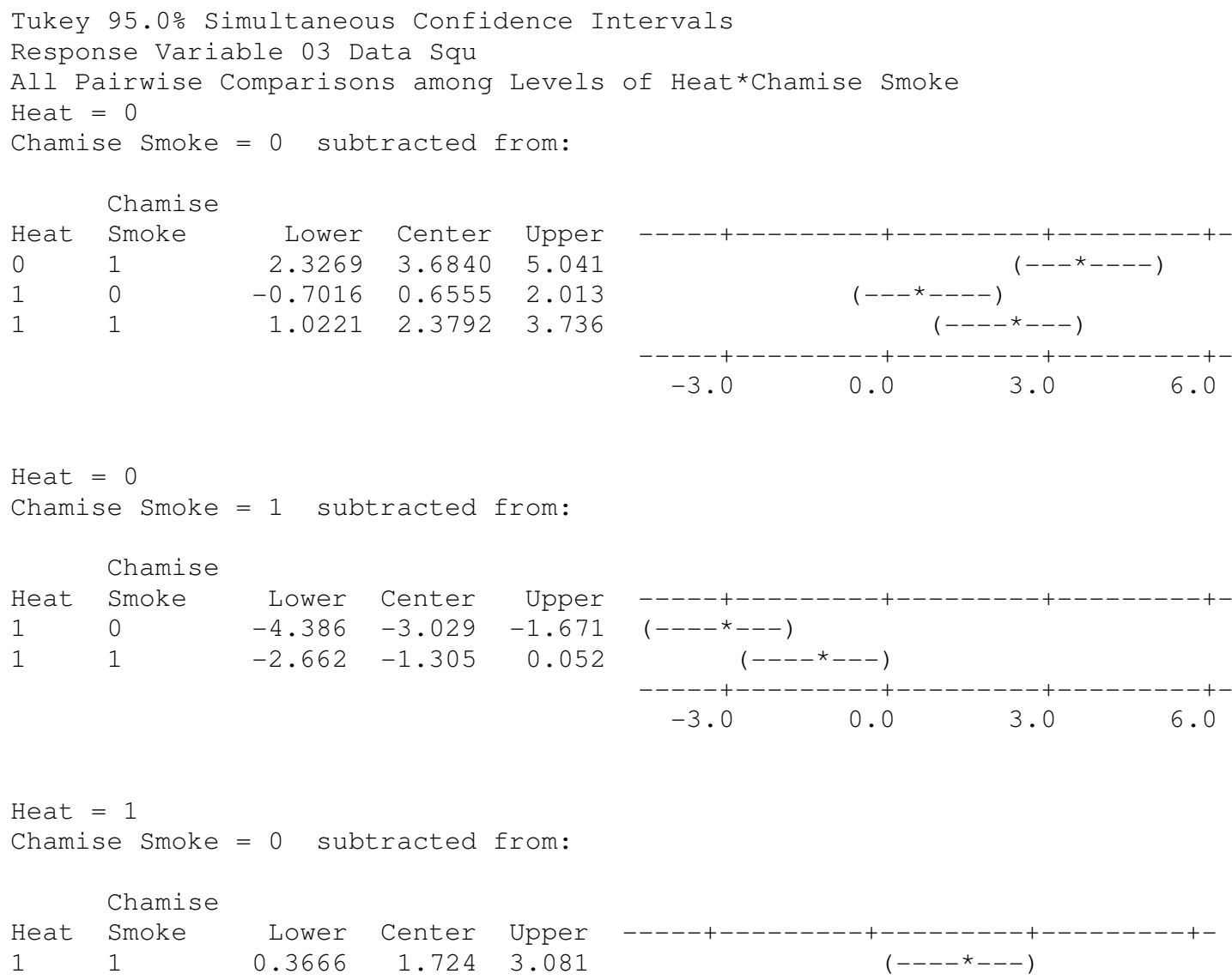

Tukey Simultaneous Tests

Response Variable 03 Data Squ

All Pairwise Comparisons among Levels of Heat*Chamise Smoke Heat $=0$

Chamise Smoke $=0$ subtracted from:

$\begin{array}{llrrrr} & \text { Chamise } & \text { Difference } & \text { SE of } & & \text { Adjusted } \\ \text { Heat } & \text { Smoke } & \text { of Means } & \text { Difference } & \text { T-Value } & \text { P-Value } \\ 0 & 1 & 3.6840 & 0.5159 & 7.141 & 0.0000 \\ 1 & 0 & 0.6555 & 0.5159 & 1.271 & 0.5847 \\ 1 & 1 & 2.3792 & 0.5159 & 4.612 & 0.0001\end{array}$

Heat $=0$

Chamise Smoke = 1 subtracted from:

$\begin{array}{llrrrr} & \text { Chamise } & \text { Difference } & \text { SE of } & & \text { Adjusted } \\ \text { Heat } & \text { Smoke } & \text { of Means } & \text { Difference } & \text { T-Value } & \text { P-Value } \\ 1 & 0 & -3.029 & 0.5159 & -5.870 & 0.0000 \\ 1 & 1 & -1.305 & 0.5159 & -2.529 & 0.0644\end{array}$

Heat $=1$

Chamise Smoke $=0$ subtracted from:

Chamise Difference SE of Adjusted




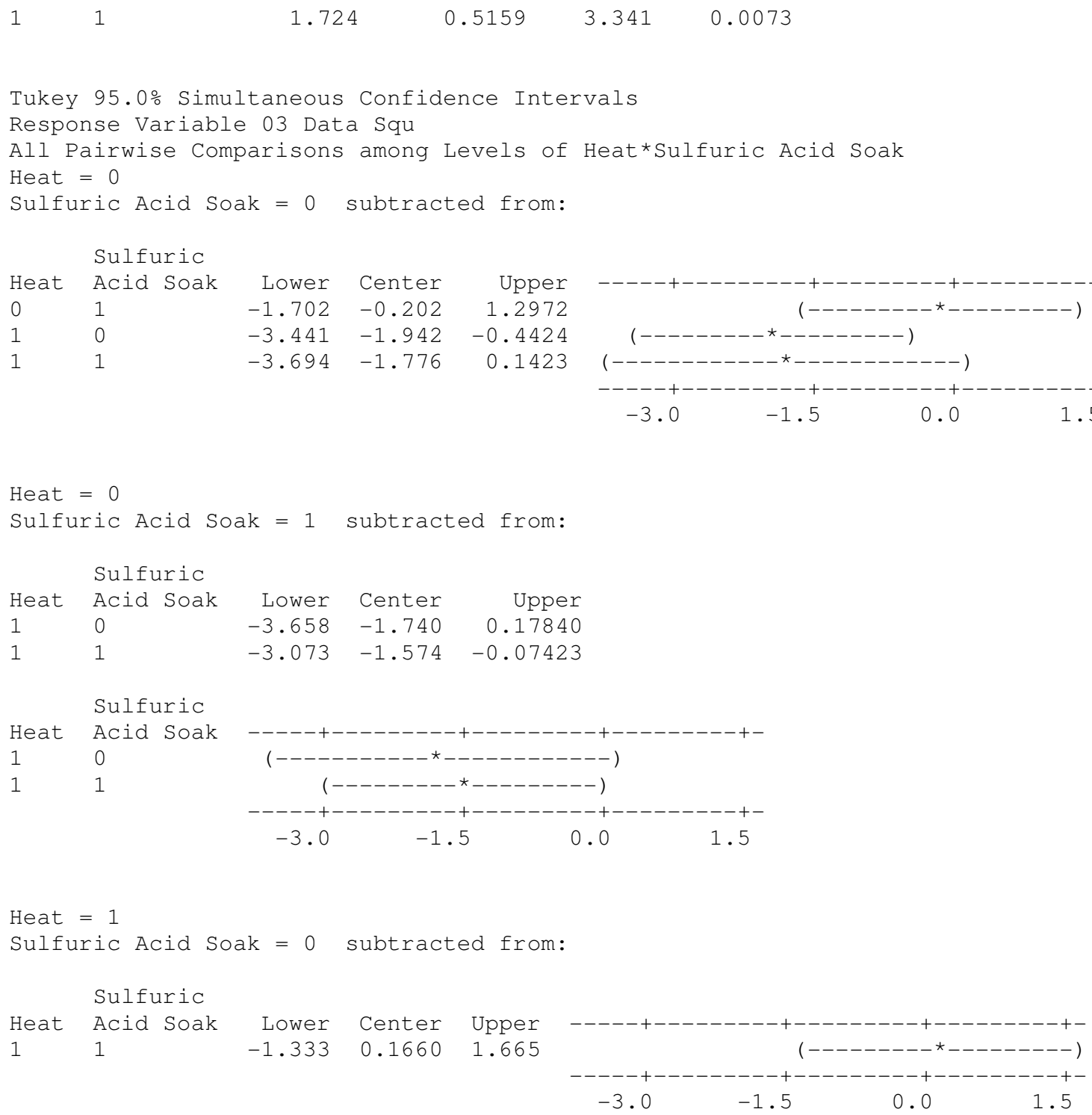



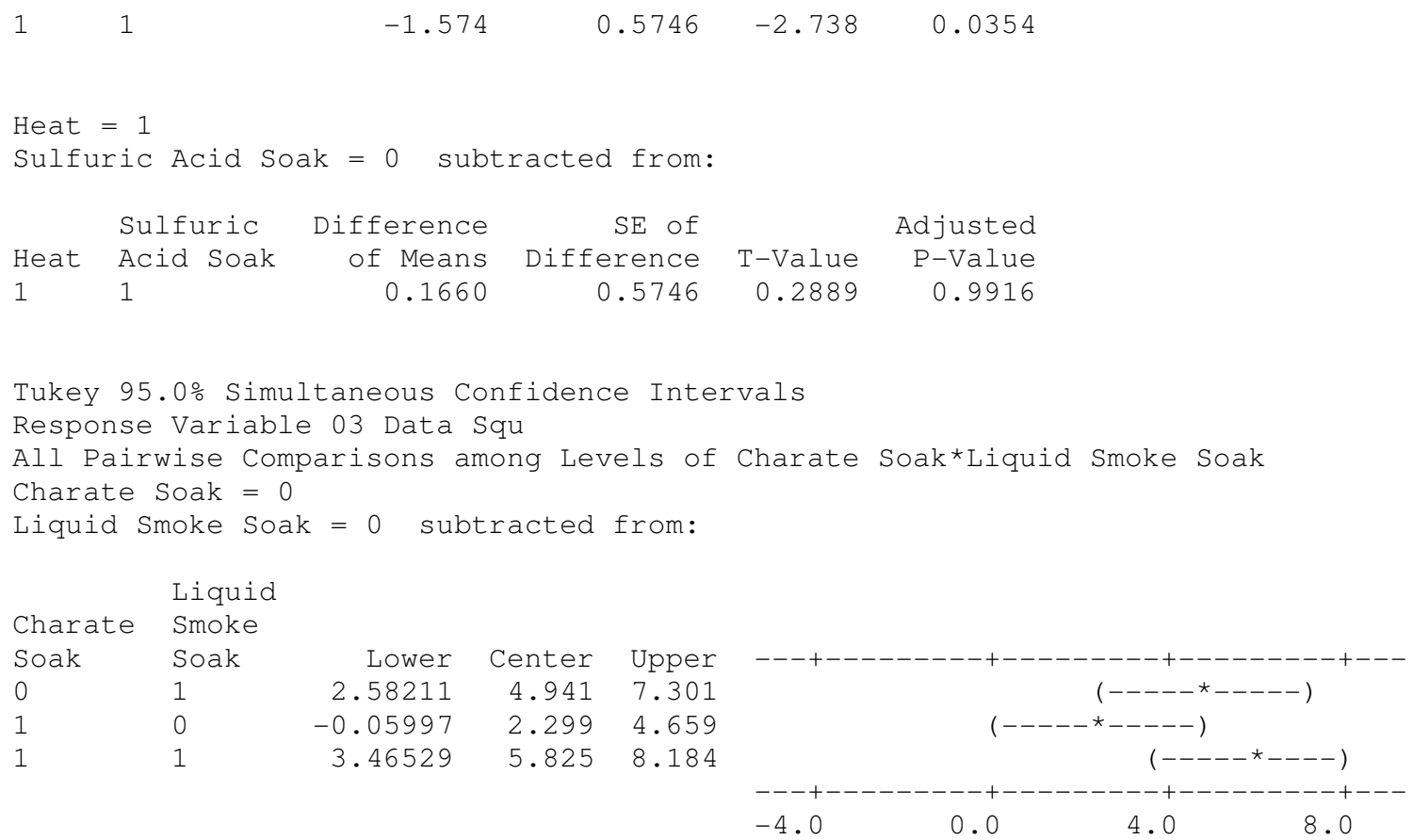

Charate Soak $=0$

Liquid Smoke Soak = 1 subtracted from:

\begin{tabular}{|c|c|c|c|c|c|}
\hline Charate & $\begin{array}{l}\text { Liquid } \\
\text { Smoke }\end{array}$ & & & & \\
\hline Soak & Soak & Lower & Center & Upper & ---+---------- \\
\hline 1 & 0 & -5.001 & -2.642 & -0.2828 & $(-----\star-----)$ \\
\hline 1 & 1 & -1.476 & 0.883 & 3.2425 & $(-----\star-----)$ \\
\hline & & & & & -4.0 \\
\hline
\end{tabular}

Charate Soak = 1

Liquid Smoke Soak $=0$ subtracted from:

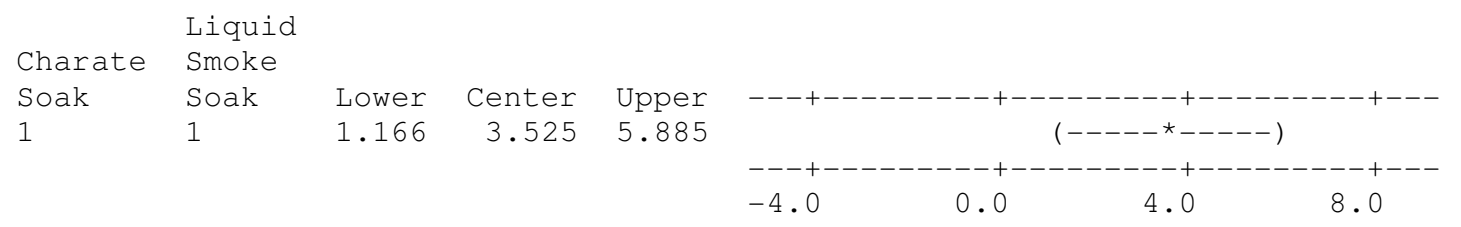

Tukey Simultaneous Tests

Response Variable 03 Data Squ

All Pairwise Comparisons among Levels of Charate Soak`Liquid Smoke Soak Charate Soak $=0$

Liquid Smoke Soak = 0 subtracted from:

$\begin{array}{llrrrr}\text { Charate } & \begin{array}{l}\text { Liquid } \\ \text { Smoke }\end{array} & \text { Difference } & \text { SE of } & & \text { Adjusted } \\ \text { Soak } & \text { Soak } & \text { of Means } & \text { Difference } & \text { T-Value } & \text { P-Value } \\ 0 & 1 & 4.941 & 0.8827 & 5.598 & 0.0000 \\ 1 & 0 & 2.299 & 0.8827 & 2.605 & 0.0582 \\ 1 & 1 & 5.825 & 0.8827 & 6.599 & 0.0000\end{array}$




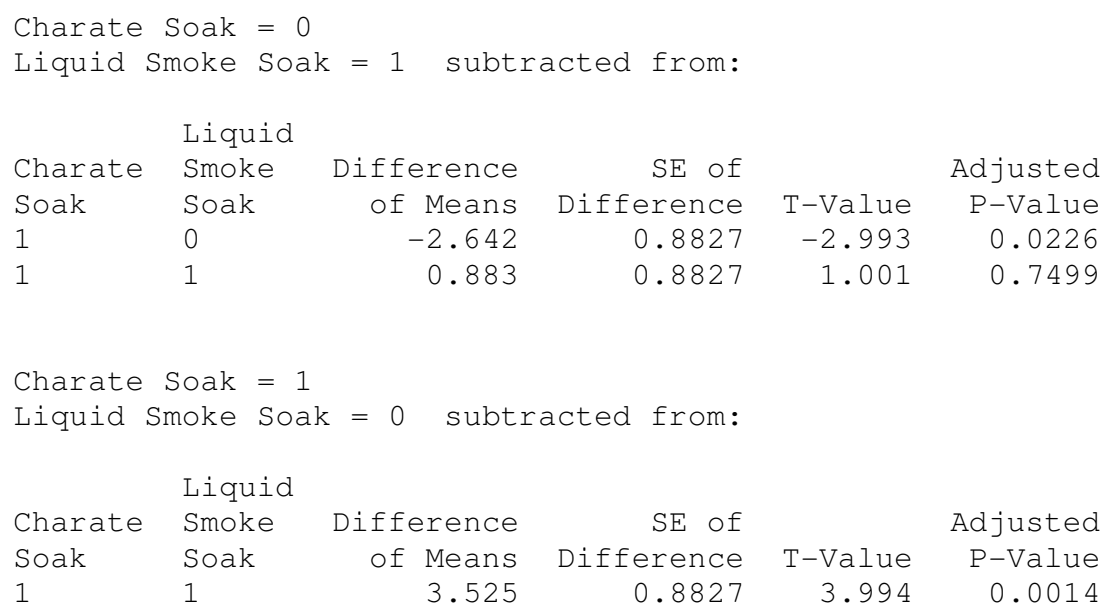




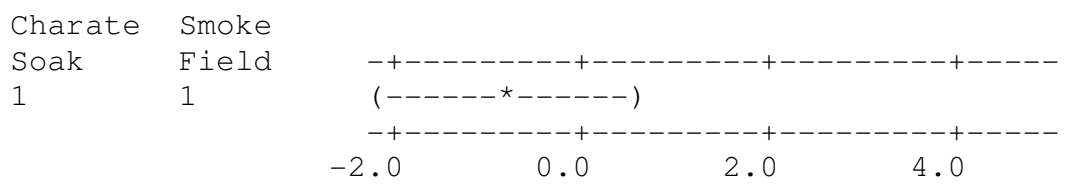

Tukey Simultaneous Tests

Response Variable 03 Data Squ

All Pairwise Comparisons among Levels of Charate Soak*Liquid Smoke Field Charate Soak = 0

Liquid Smoke Field $=0$ subtracted from:

$\begin{array}{llrrrr} & \text { Liquid } & & & \\ \text { Charate } & \text { Smoke } & \text { Difference } & \text { SE of } & & \text { Adjusted } \\ \text { Soak } & \text { Field } & \text { of Means } & \text { Difference } & \text { T-Value } & \text { P-Value } \\ 0 & 1 & 0.3494 & 0.5240 & 0.6668 & 0.9090 \\ 1 & 0 & 2.2994 & 0.5240 & 4.3884 & 0.0004 \\ 1 & 1 & 1.4200 & 0.5240 & 2.7101 & 0.0455\end{array}$

Charate Soak $=0$

Liquid Smoke Field $=1$ subtracted from:

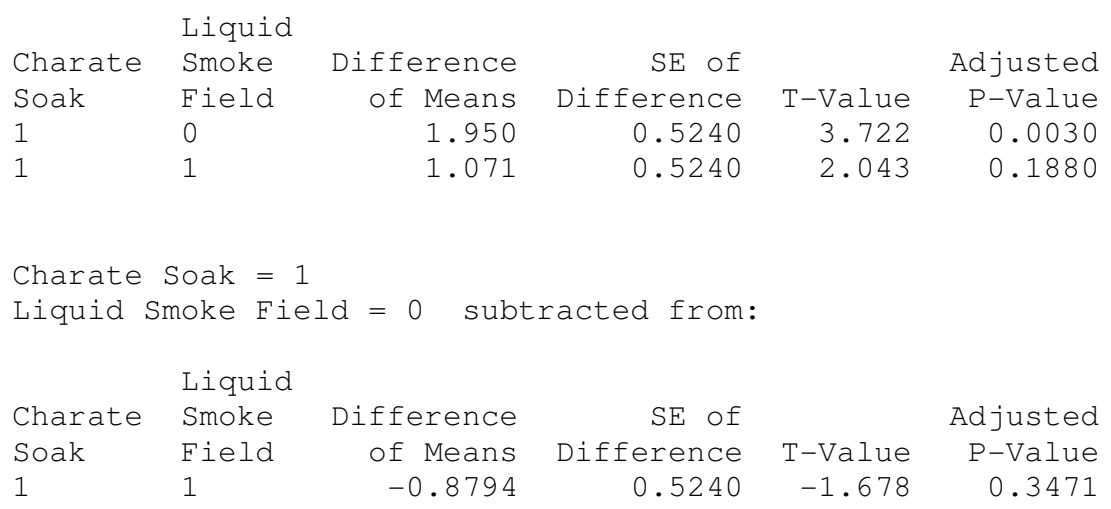

Tukey 95.0\% Simultaneous Confidence Intervals

Response Variable 03 Data Squ

All Pairwise Comparisons among Levels of Charate Soak*Chamise Smoke Charate Soak $=0$

Chamise Smoke = 0 subtracted from:

$\begin{array}{llrrr}\text { Charate } & \text { Chamise } & & & \\ \text { Soak } & \text { Smoke } & \text { Lower } & \text { Center } & \text { Upper } \\ 0 & 1 & 2.6667 & 4.221 & 5.776 \\ 1 & 0 & 0.7447 & 2.299 & 3.854 \\ 1 & 1 & 2.6331 & 4.188 & 5.742\end{array}$

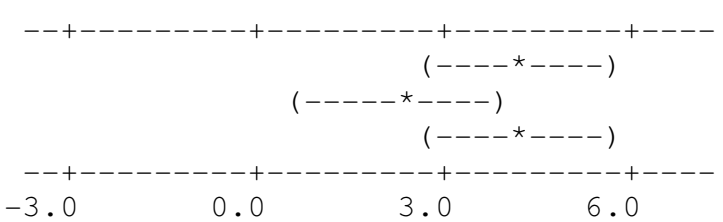

Charate Soak $=0$

Chamise Smoke $=1$ subtracted from:

$\begin{array}{llrrr}\text { Charate } & \text { Chamise } & & & \\ \text { Soak } & \text { Smoke } & \text { Lower } & \text { Center } & \text { Upper } \\ 1 & 0 & -3.477 & -1.922 & -0.3673 \\ 1 & 1 & -1.588 & -0.034 & 1.5210\end{array}$




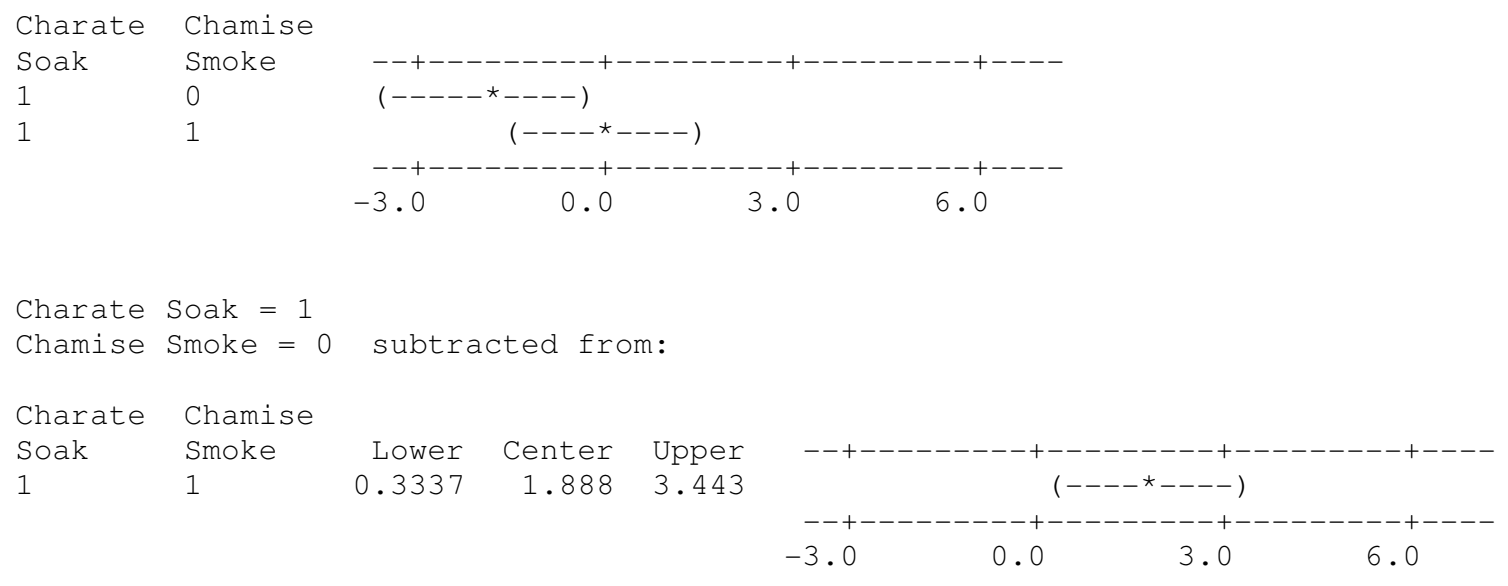

Tukey Simultaneous Tests

Response Variable 03 Data Squ

All Pairwise Comparisons among Levels of Charate Soak*Chamise Smoke

Charate Soak $=0$

Chamise Smoke $=0$ subtracted from:

$\begin{array}{llrrrr}\text { Charate } & \text { Chamise } & \text { Difference } & \text { SE of } & & \text { Adjusted } \\ \text { Soak } & \text { Smoke } & \text { of Means } & \text { Difference } & \text { T-Value } & \text { P-Value } \\ 0 & 1 & 4.221 & 0.5816 & 7.258 & 0.0000 \\ 1 & 0 & 2.299 & 0.5816 & 3.953 & 0.0015 \\ 1 & 1 & 4.188 & 0.5816 & 7.200 & 0.0000\end{array}$

Charate Soak $=0$

Chamise Smoke $=1$ subtracted from:

$\begin{array}{llrrrr}\text { Charate } & \text { Chamise } & \text { Difference } & \text { SE of } & & \text { Adjusted } \\ \text { Soak } & \text { Smoke } & \text { of Means } & \text { Difference } & \text { T-Value } & \text { P-Value } \\ 1 & 0 & -1.922 & 0.5816 & -3.304 & 0.0099 \\ 1 & 1 & -0.034 & 0.5816 & -0.058 & 0.9999\end{array}$

$\begin{array}{llrrrr}\text { Charate Soak }=1 & \\ \text { Chamise Smoke }=0 & \text { subtracted from: } & & \\ \text { Charate } & \text { Chamise } & \text { Difference } & \text { SE of } & & \text { Adjusted } \\ \text { Soak } & \text { Smoke } & \text { of Means } & \text { Difference } & \text { T-Value } & \text { P-Value } \\ 1 & 1 & 1.888 & 0.5816 & 3.247 & 0.0116\end{array}$

Tukey 95.0\% Simultaneous Confidence Intervals

Response Variable 03 Data Squ

All Pairwise Comparisons among Levels of Charate Soak*Sulfuric Acid Soak Charate Soak = 0

Sulfuric Acid Soak = 0 subtracted from:

Charate Sulfuric

Soak Acid Soak Lower Center Upper

$\begin{array}{rrrrr}0 & 1 & -2.133 & -0.1003 & 1.933 \\ 1 & 0 & -1.386 & 0.6470 & 2.680\end{array}$

$\begin{array}{lllll}1 & 1 & -0.671 & 1.3625 & 3.396\end{array}$

Charate Sulfuric

Soak Acid Soak

01 (----------- +------------$)$ 


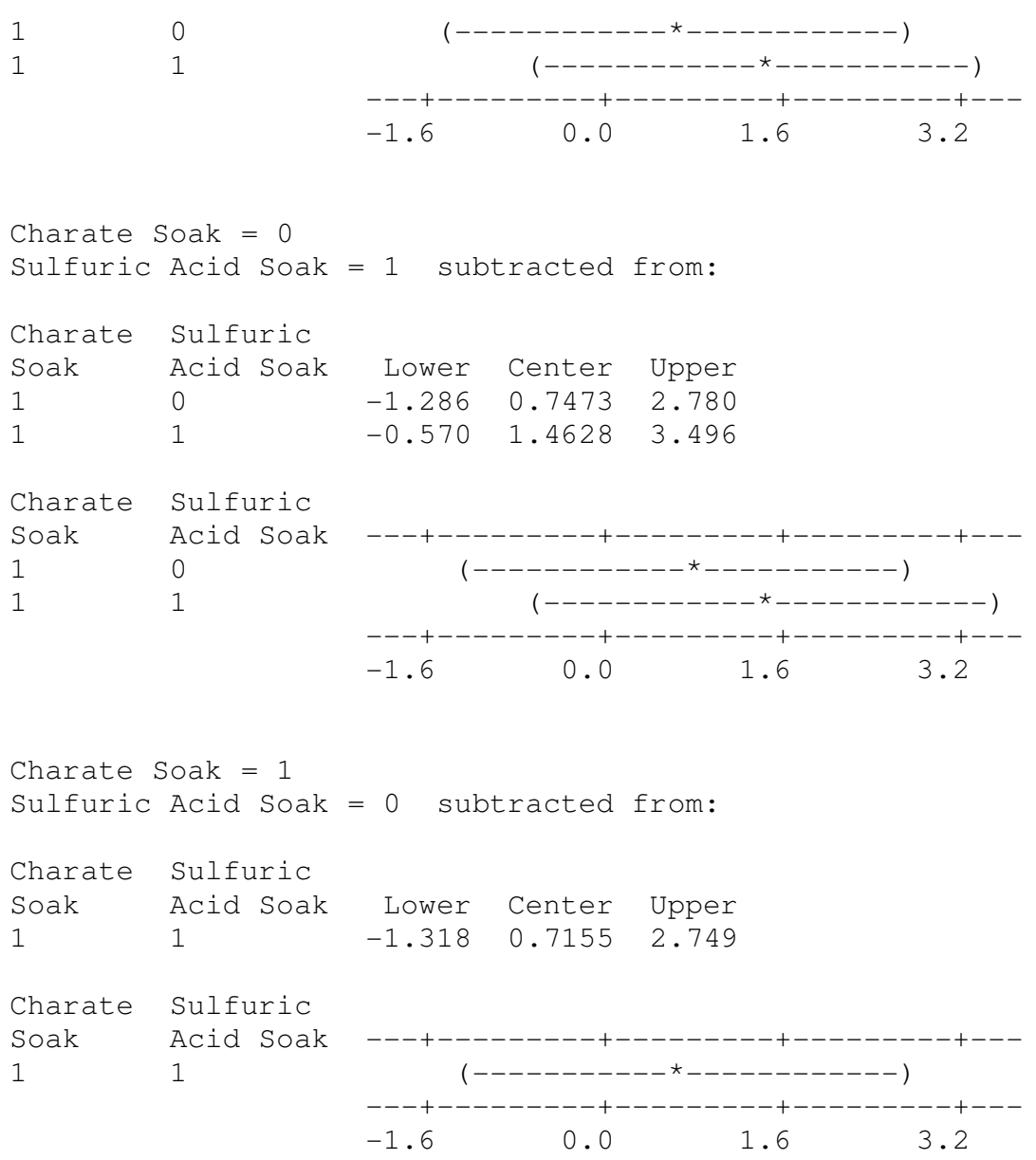

Tukey Simultaneous Tests

Response Variable 03 Data Squ

All Pairwise Comparisons among Levels of Charate Soak*Sulfuric Acid Soak Charate $\mathrm{Soak}=0$

Sulfuric Acid Soak = 0 subtracted from:

$\begin{array}{llrrrr}\text { Charate } & \text { Sulfuric } & \text { Difference } & \text { SE of } & & \text { Adjusted } \\ \text { Soak } & \text { Acid Soak } & \text { of Means } & \text { Difference } & \text { T-Value } & \text { P-Value } \\ 0 & 1 & -0.1003 & 0.7771 & -0.1291 & 0.9992 \\ 1 & 0 & 0.6470 & 0.7771 & 0.8325 & 0.8389 \\ 1 & 1 & 1.3625 & 0.7771 & 1.7533 & 0.3026\end{array}$

Charate Soak $=0$

Sulfuric Acid Soak = 1 subtracted from:

$\begin{array}{llrrrr}\text { Charate } & \text { Sulfuric } & \text { Difference } & \text { SE of } & & \text { Adjusted } \\ \text { Soak } & \text { Acid Soak } & \text { of Means } & \text { Difference } & \text { T-Value } & \text { P-Value } \\ 1 & 0 & 0.7473 & 0.7771 & 0.9616 & 0.7715 \\ 1 & 1 & 1.4628 & 0.7771 & 1.8823 & 0.2428\end{array}$

Charate Soak $=1$

Sulfuric Acid Soak = 0 subtracted from:

Charate Sulfuric Difference SE of Adjusted Soak Acid Soak of Means Difference T-Value P-Value 


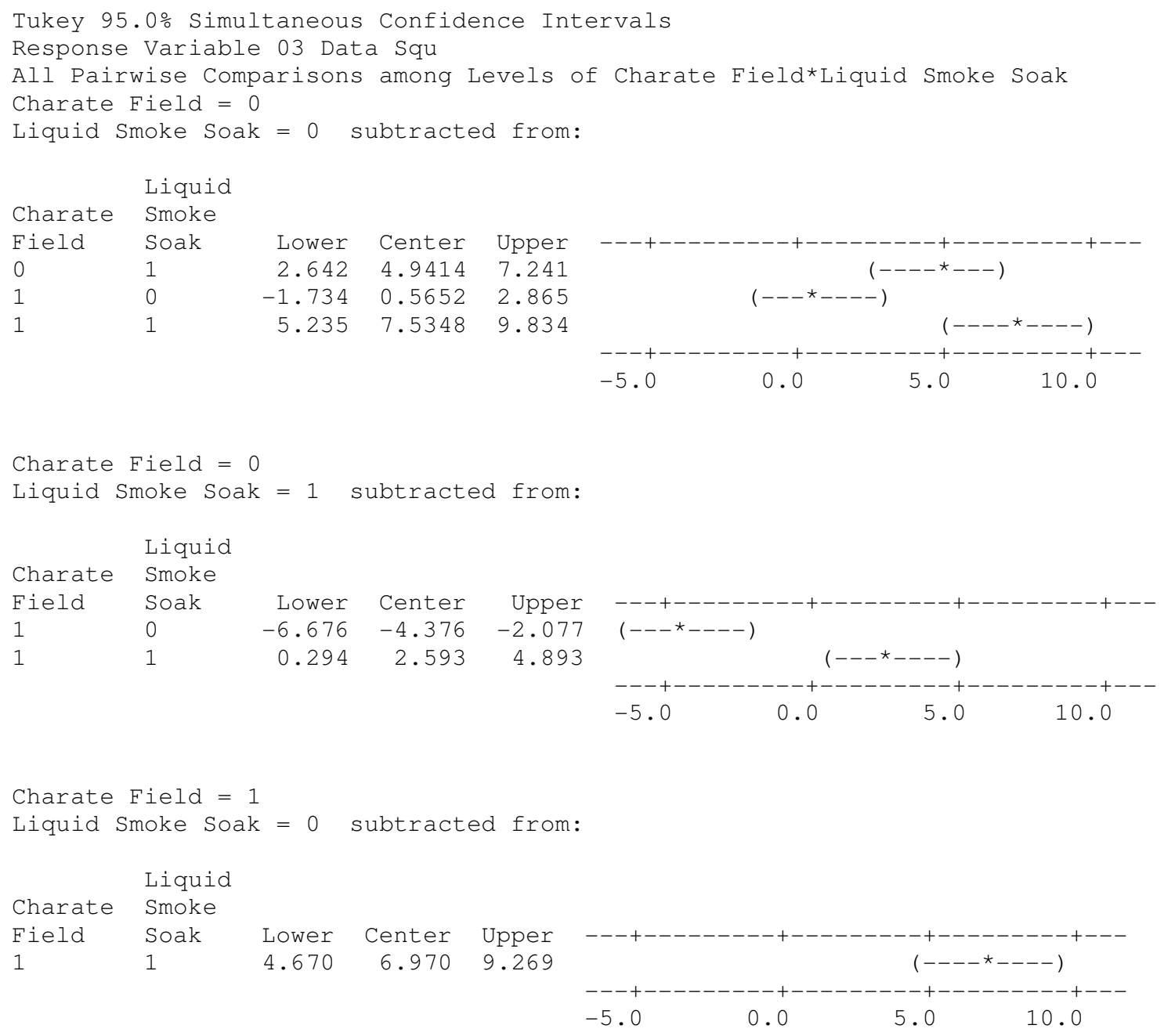

Tukey Simultaneous Tests

Response Variable 03 Data Squ

All Pairwise Comparisons among Levels of Charate FieldLiquid Smoke Soak Charate Field = 0

Liquid Smoke Soak $=0$ subtracted from:

$\begin{array}{llrrrr} & \text { Liquid } & & & \\ \text { Charate } & \text { Smoke } & \text { Difference } & \text { SE of } & & \text { Adjusted } \\ \text { Field } & \text { Soak } & \text { of Means } & \text { Difference } & \text { T-Value } & \text { P-Value } \\ 0 & 1 & 4.9414 & 0.8603 & 5.7437 & 0.0000 \\ 1 & 0 & 0.5652 & 0.8603 & 0.6569 & 0.9126 \\ 1 & 1 & 7.5348 & 0.8603 & 8.7582 & 0.0000\end{array}$

Charate Field $=0$

Liquid Smoke Soak $=1$ subtracted from:

$\begin{array}{llrrrr}\text { Charate } & \begin{array}{l}\text { Liquid } \\ \text { Smoke }\end{array} & \text { Difference } & \text { SE of } & & \text { Adjusted } \\ \text { Field } & \text { Soak } & \text { of Means } & \text { Difference } & \text { T-Value } & \text { P-Value } \\ 1 & 0 & -4.376 & 0.8603 & -5.087 & 0.0001\end{array}$




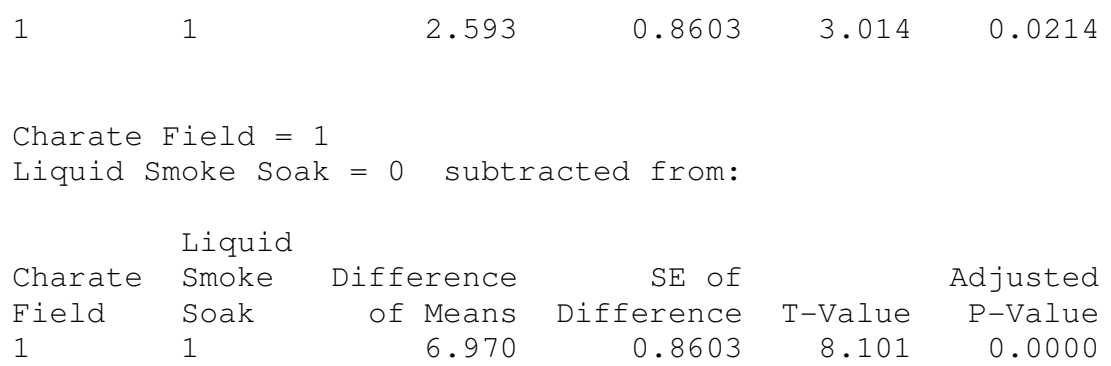

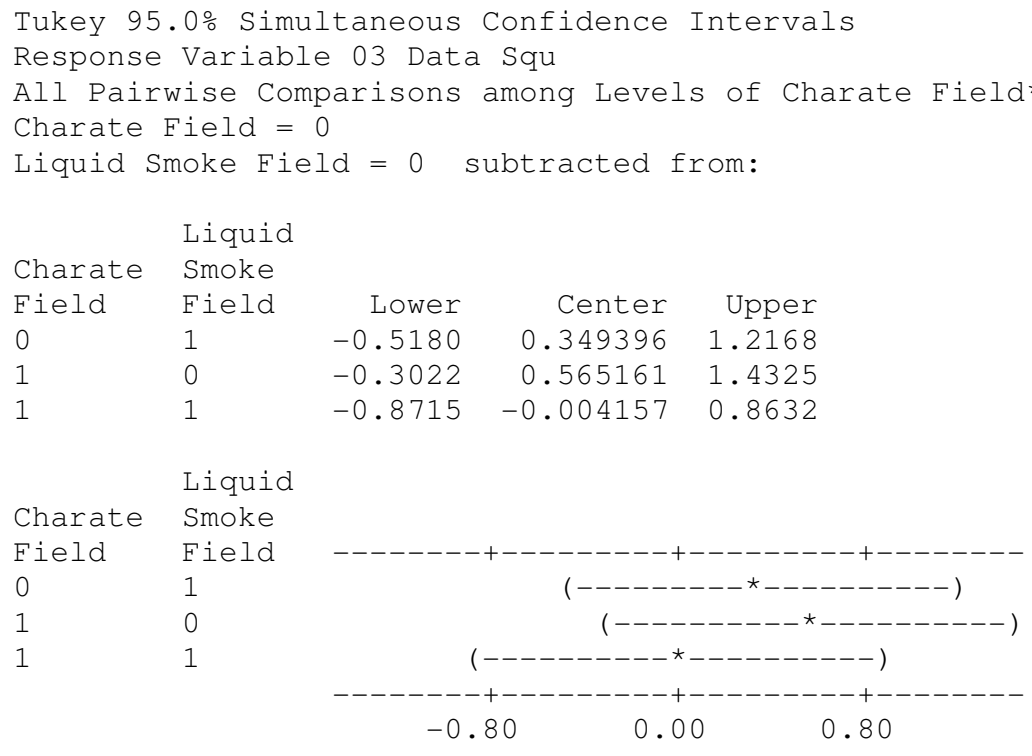




$\begin{array}{llrrrr} & \text { Liquid } & & & \\ \text { Charate } & \text { Smoke } & \text { Difference } & \text { SE of } & & \text { Adjusted } \\ \text { Field } & \text { Field } & \text { of Means } & \text { Difference } & \text { T-Value } & \text { P-Value } \\ 0 & 1 & 0.349396 & 0.3245 & 1.07669 & 0.7054 \\ 1 & 0 & 0.565161 & 0.3245 & 1.74159 & 0.3150 \\ 1 & 1 & -0.004157 & 0.3245 & -0.01281 & 1.0000\end{array}$

Charate Field $=0$

Liquid Smoke Field $=1$ subtracted from:

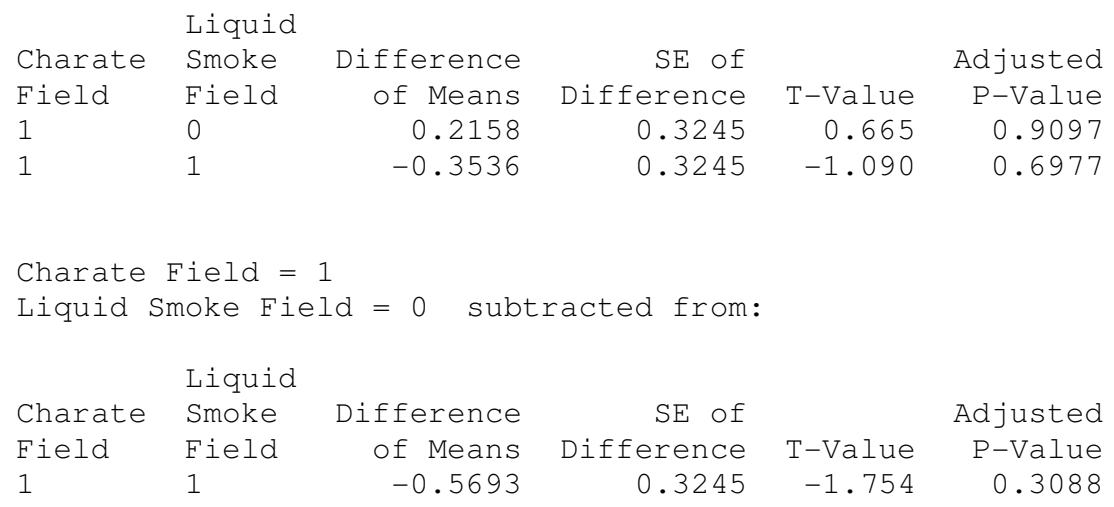

Tukey 95.0\% Simultaneous Confidence Intervals

Response Variable 03 Data Squ

All Pairwise Comparisons among Levels of Charate Field*Chamise Smoke Charate Field = 0

Chamise Smoke $=0$ subtracted from:

Charate Chamise

Field Smoke Lower Center Upper

$\begin{array}{lllll}0 & 1 & 2.7598 & 4.2213 & 5.683\end{array}$

$\begin{array}{lllll}1 & 0 & -0.8963 & 0.5652 & 2.027\end{array}$

$\begin{array}{lllll}1 & 1 & 1.1057 & 2.5672 & 4.029\end{array}$

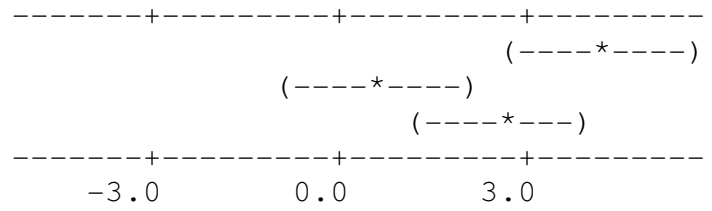

Charate Field $=0$

Chamise Smoke = 1 subtracted from:

Charate Chamise

Field Smoke Lower Center Upper

$\begin{array}{lllll}1 & 0 & -5.118 & -3.656 & -2.195\end{array}$

$\begin{array}{lllll}1 & 1 & -3.116 & -1.654 & -0.193\end{array}$

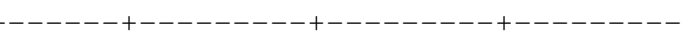

$(----\star----)$ $(---\star----)$

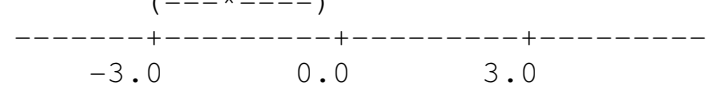

Charate Field $=1$

Chamise Smoke $=0$ subtracted from:

Charate Chamise

Field Smoke Lower Center Upper

$\begin{array}{lllll}1 & 1 & 0.5405 & 2.002 & 3.464\end{array}$

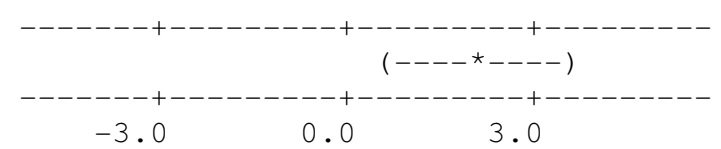


Tukey Simultaneous Tests

Response Variable 03 Data Squ

All Pairwise Comparisons among Levels of Charate Field*Chamise Smoke

Charate Field = 0

Chamise Smoke $=0$ subtracted from:

$\begin{array}{llrrrr}\text { Charate } & \text { Chamise } & \text { Difference } & \text { SE of } & & \text { Adjusted } \\ \text { Field } & \text { Smoke } & \text { of Means } & \text { Difference } & \text { T-Value } & \text { P-Value } \\ 0 & 1 & 4.2213 & 0.5468 & 7.720 & 0.0000 \\ 1 & 0 & 0.5652 & 0.5468 & 1.034 & 0.7308 \\ 1 & 1 & 2.5672 & 0.5468 & 4.695 & 0.0002\end{array}$

\begin{tabular}{|c|c|c|c|c|c|}
\hline Chamise & Smoke $=1$ & subtracted & from: & & \\
\hline Charate & Chamise & Difference & $S E$ of & & Adjusted \\
\hline Field & Smoke & of Means & Difference & T-Value & P-Value \\
\hline 1 & 0 & -3.656 & 0.5468 & -6.687 & 0.0000 \\
\hline 1 & 1 & -1.654 & 0.5468 & -3.025 & 0.0208 \\
\hline Charate & Field $=1$ & & & & \\
\hline Chamise & Smoke $=0$ & subtracted & from: & & \\
\hline Charate & Chamise & Difference & SE of & & Adjusted \\
\hline Field & Smoke & of Means & Difference & T-Value & P-Value \\
\hline 1 & 1 & 2.002 & 0.5468 & 3.661 & 0.0036 \\
\hline
\end{tabular}

Tukey 95.0\% Simultaneous Confidence Intervals

Response Variable 03 Data Squ

All Pairwise Comparisons among Levels of Charate Field*Sulfuric Acid Soak Charate Field = 0

Sulfuric Acid Soak = 0 subtracted from:

Charate Sulfuric

Field Acid Soak Lower Center Upper

$\begin{array}{lllll}0 & 1 & -2.498 & -0.1003 & 2.297\end{array}$

$\begin{array}{lllll}1 & 0 & -2.400 & -0.0025 & 2.395\end{array}$

$1 \quad 1 \quad-1.920 \quad 0.4776 \quad 2.875$

Charate Sulfuric

Field Acid Soak

$0 \quad 1$

$1 \quad 0$
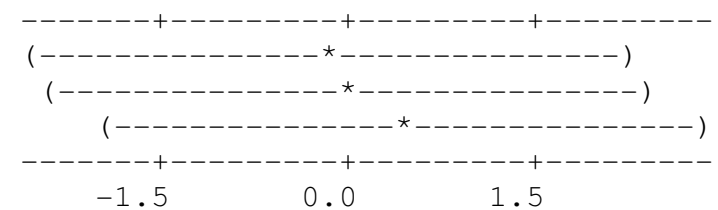

Charate Field $=0$

Sulfuric Acid Soak = 1 subtracted from:

Charate Sulfuric

Field Acid Soak Lower Center Upper

$\begin{array}{lllll}1 & 0 & -2.300 & 0.09782 & 2.495\end{array}$

$\begin{array}{lllll}1 & 1 & -1.820 & 0.57792 & 2.976\end{array}$

Charate Sulfuric

Field Acid Soak

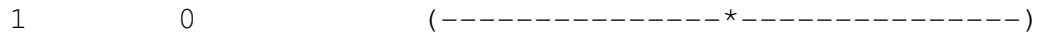




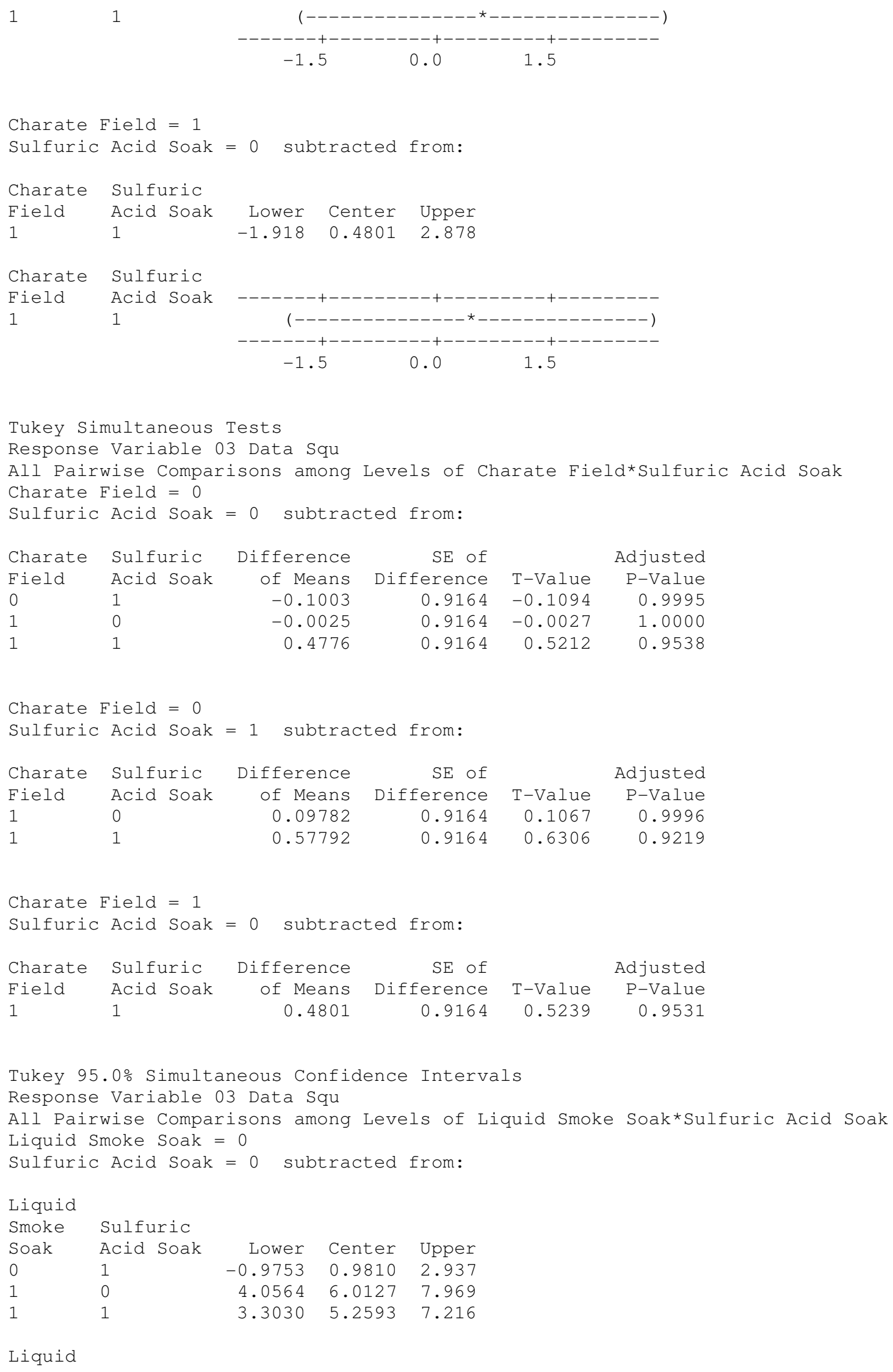

Tukey Simultaneous Tests

Response Variable 03 Data Squ

All Pairwise Comparisons among Levels of Charate Field*Sulfuric Acid Soak Charate Field $=0$

Sulfuric Acid Soak = 0 subtracted from:

$\begin{array}{llrrrr}\text { Charate } & \text { Sulfuric } & \text { Difference } & \text { SE of } & & \text { Adjusted } \\ \text { Field } & \text { Acid Soak } & \text { Of Means } & \text { Difference } & \text { T-Value } & \text { P-Value } \\ 0 & 1 & -0.1003 & 0.9164 & -0.1094 & 0.9995 \\ 1 & 0 & -0.0025 & 0.9164 & -0.0027 & 1.0000 \\ 1 & 1 & 0.4776 & 0.9164 & 0.5212 & 0.9538\end{array}$




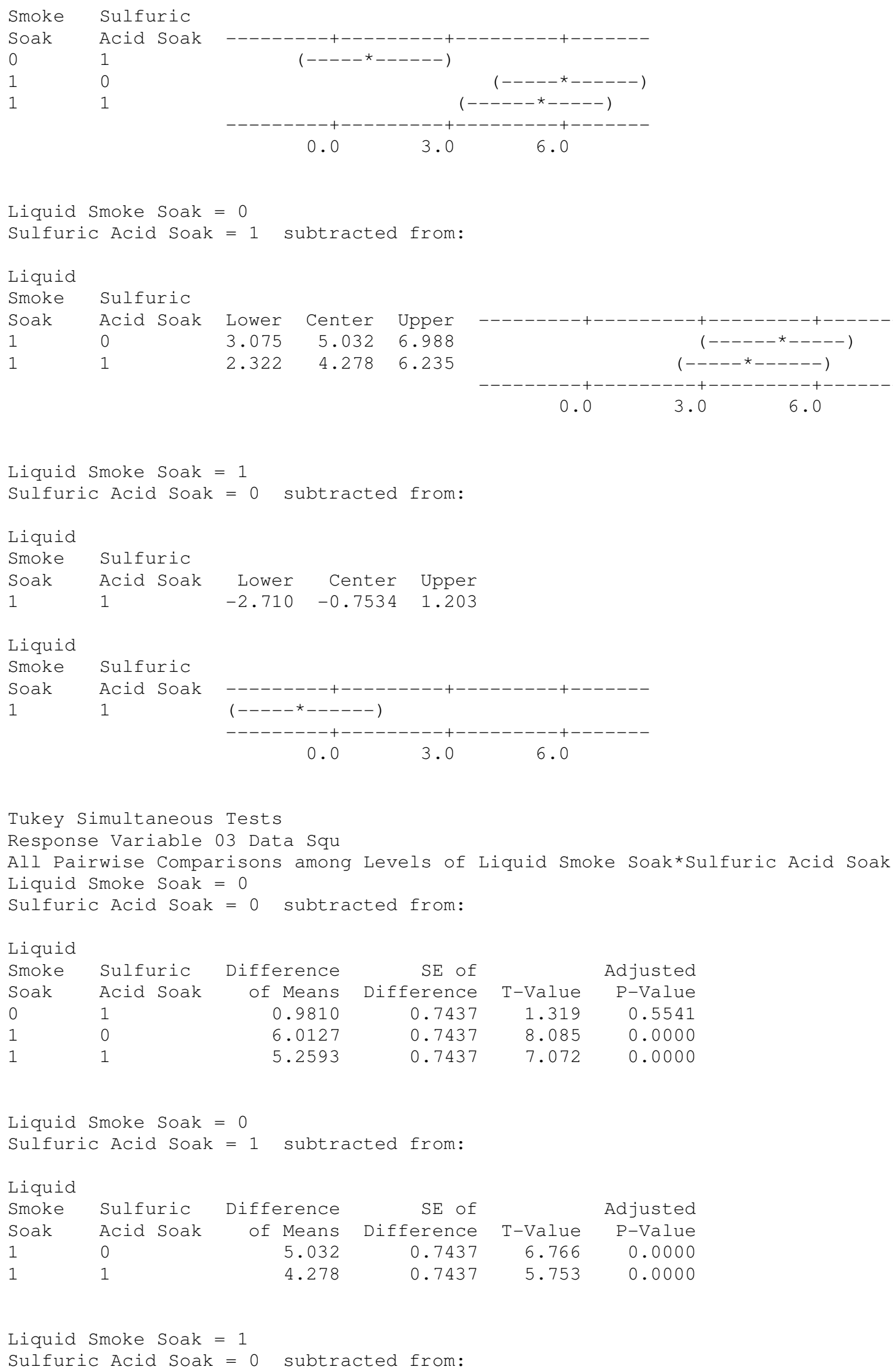

0.0

3.0

6.0

Liquid Smoke Soak $=0$

Sulfuric Acid Soak = 1 subtracted from:

Liquid

Smoke Sulfuric

Soak Acid Soak

1

$1-1$

$\begin{array}{rrr}\text { Lower } & \text { Center } & \text { Upper } \\ 3.075 & 5.032 & 6.988 \\ 2.322 & 4.278 & 6.235\end{array}$

Liquid Smoke Soak $=1$

Sulfuric Acid Soak = 0 subtracted from:

Liquid

Smoke Sulfuric

Soak Acid Soak Lower Center Upper

$\begin{array}{lllll}1 & 1 & -2.710 & -0.7534 & 1.203\end{array}$

Liquid

Smoke Sulfuric

Soak Acid Soak

1

Tukey Simultaneous Tests

Response Variable 03 Data Squ

All Pairwise Comparisons among Levels of Liquid Smoke Soak*Sulfuric Acid Soak Liquid Smoke Soak = 0

Sulfuric Acid Soak = 0 subtracted from:

Liquid

Smoke Sulfuric Difference SE of

$\begin{array}{llrlrl}\text { Smoke } & \text { Sulfuric } & \text { Difference } & \text { SE of } & & \text { Adjusted } \\ \text { Soak } & \text { Acid Soak } & \text { of Means } & \text { Difference } & \text { T-Value } & \text { P-Value }\end{array}$

0.9810

T-Value

6.0127

0.7437

1.319

5.2593

8.085

$\mathrm{P}-\mathrm{Value}$

0.5541

0.0000

1

$0.7437 \quad 7.072$

0.0000

Liquid Smoke Soak $=0$

Sulfuric Acid Soak = 1 subtracted from:

Liquid

Smoke

Soak Acid Soak

Difference

SE of

Adjusted

$1 \quad 0$

of Means

Difference

5.032

0.7437

T-Value

$\mathrm{P}$-Value

11

4.278

0.7437

6.766

0.0000

Liquid Smoke Soak $=1$

Sulfuric Acid Soak = 0 subtracted from: 


\begin{tabular}{llrrrr} 
Liquid & \multicolumn{3}{c}{} & & \\
Smoke & Sulfuric & Difference & SE of & & Adjusted \\
Soak & Acid Soak & of Means & Difference & T-Value & P-Value \\
1 & 1 & -0.7534 & 0.7437 & -1.013 & 0.7424
\end{tabular}

Tukey 95.0\% Simultaneous Confidence Intervals

Response Variable 03 Data Squ

All Pairwise Comparisons among Levels of Liquid Smoke Field*Sulfuric Acid Soak Liquid Smoke Field $=0$

Sulfuric Acid Soak $=0$ subtracted from:

Liquid

Smoke Sulfuric

Field Acid Soak Lower Center Upper

$\begin{array}{lllll}0 & 1 & -0.219 & 0.98100 & 2.181\end{array}$

$\begin{array}{lllll}1 & 0 & -1.148 & 0.05142 & 1.251\end{array}$

$\begin{array}{lllll}1 & 1 & -1.003 & 0.19673 & 1.397\end{array}$

Liquid

Smoke Sulfuric

Field Acid Soak

$0 \quad 1$

$1 \quad 0$

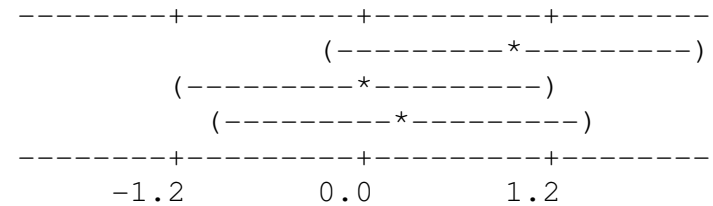

Liquid Smoke Field $=0$

Sulfuric Acid Soak = 1 subtracted from:

Liquid

Smoke Sulfuric

Field Acid Soak Lower Center Upper

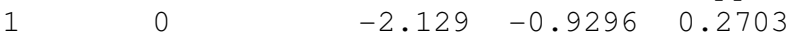

$\begin{array}{lllll}1 & 1 & -1.984 & -0.7843 & 0.4156\end{array}$

Liquid

Smoke Sulfuric

Field Acid Soak

$1 \quad 0$

$1-1$

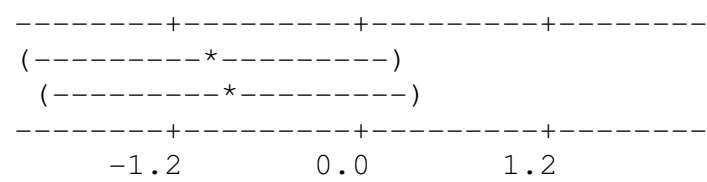

Liquid Smoke Field $=1$

Sulfuric Acid Soak = 0 subtracted from:

Liquid

Smoke Sulfuric

Field Acid Soak Lower Center Upper

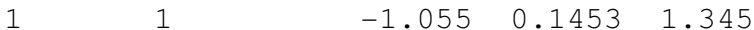

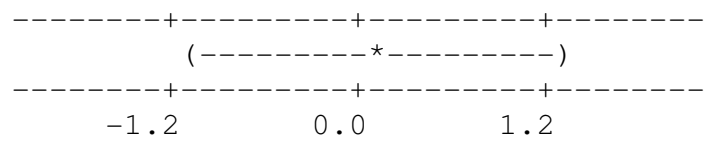

Tukey Simultaneous Tests

Response Variable 03 Data Squ

All Pairwise Comparisons among Levels of Liquid Smoke Field*Sulfuric Acid Soak

Liquid Smoke Field $=0$ 


\begin{tabular}{|c|c|c|c|c|c|}
\hline \multicolumn{6}{|l|}{ Liquid } \\
\hline Smoke & Sulfuric & Difference & SE of & & Adjusted \\
\hline Field & Acid Soak & of Means & Difference & T-Value & P-Value \\
\hline 0 & 1 & 0.98100 & 0.4561 & 2.1506 & 0.1478 \\
\hline 1 & 0 & 0.05142 & 0.4561 & 0.1127 & 0.9995 \\
\hline 1 & 1 & 0.19673 & 0.4561 & 0.4313 & 0.9729 \\
\hline \\
\hline Sulfuric & C Acid Soak & $=1$ subtra & cted from: & & \\
\hline \multicolumn{6}{|l|}{ Liquid } \\
\hline Smoke & Sulfuric & Difference & SE of & & Adjusted \\
\hline Field & Acid Soak & of Means & Difference & T-Value & P-Value \\
\hline 1 & 0 & -0.9296 & 0.4561 & -2.038 & 0.1845 \\
\hline 1 & 1 & -0.7843 & 0.4561 & -1.719 & 0.3218 \\
\hline Liquid & Smoke Field & $=1$ & & & \\
\hline Sulfuric & C Acid Soak & $=0$ subtra & cted from: & & \\
\hline \multicolumn{6}{|l|}{ Liquid } \\
\hline Smoke & Sulfuric & Difference & SE of & & Adjusted \\
\hline Field & Acid Soak & of Means & Difference & T-Value & P-Value \\
\hline 1 & 1 & 0.1453 & 0.4561 & 0.3185 & 0.9887 \\
\hline
\end{tabular}

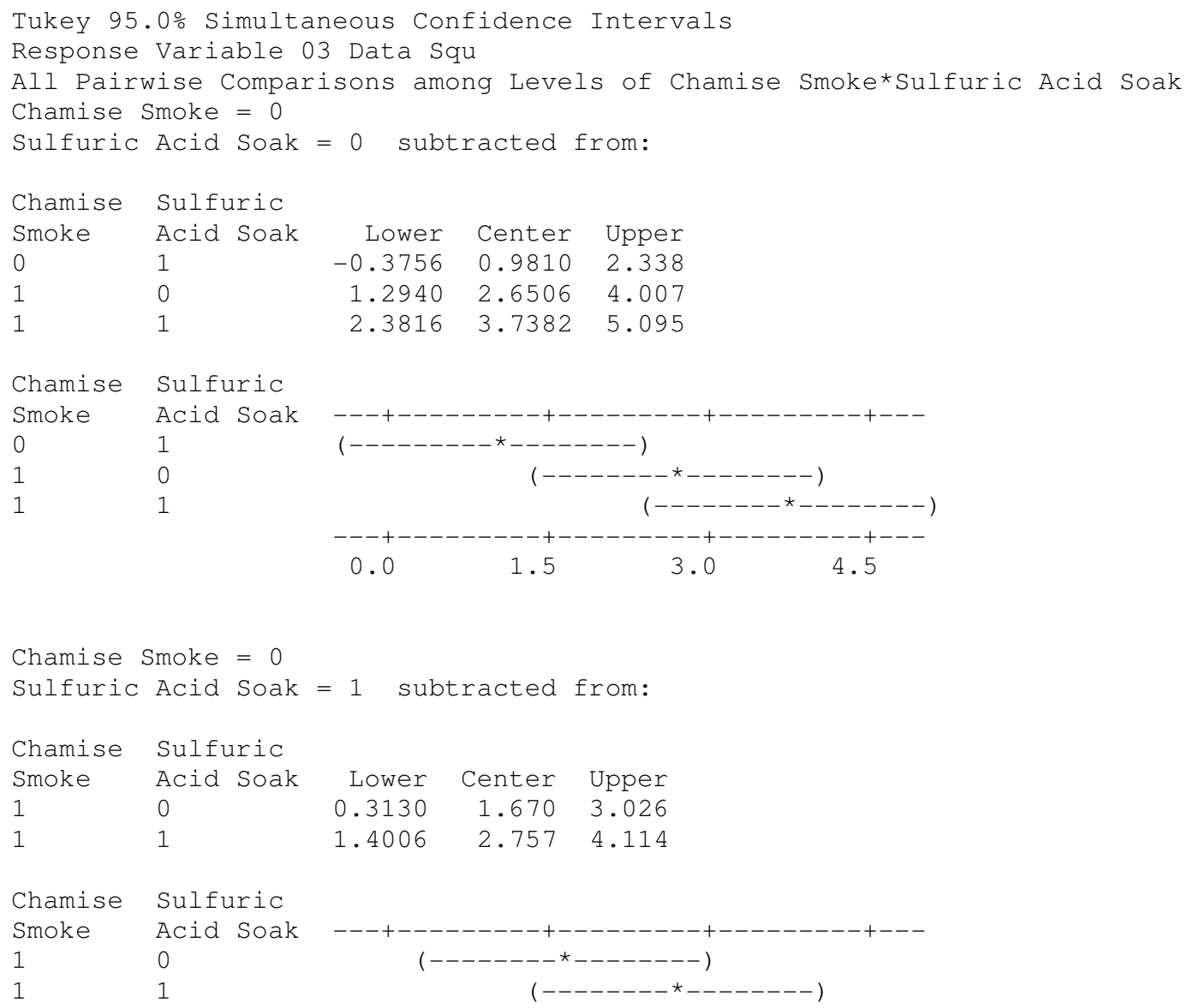

Chamise Smoke $=0$

Sulfuric Acid Soak = 1 subtracted from:

Chamise Sulfuric

Smoke Acid Soak Lower Center Upper

$\begin{array}{lllll}1 & 0 & 0.3130 & 1.670 & 3.026\end{array}$

$\begin{array}{lllll}1 & 1 & 1.4006 & 2.757 & 4.114\end{array}$

Chamise Sulfuric

Smoke Acid Soak

1

1 

0.0
1.5
3.0
4.5

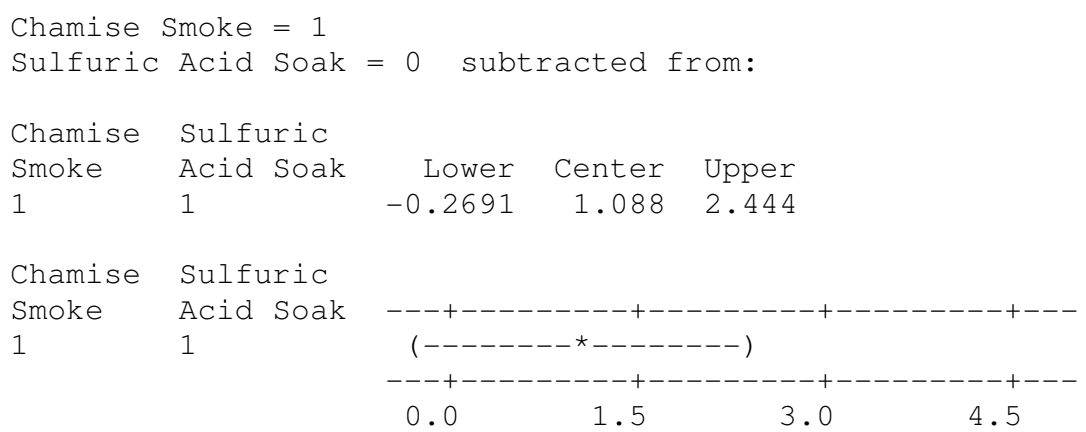




\section{Minitab Results of General Linear Model and Tukey's HSD test on the 2003-2004 Data}

$\begin{array}{llrl}\text { Factor } & \text { Type } & \text { Levels } & \text { Values } \\ \text { Heat } & \text { fixed } & 2 & 0,1 \\ \text { Charate Soak } & \text { fixed } & 2 & 0,1 \\ \text { Charate Field } & \text { fixed } & 2 & 0,1 \\ \text { Liquid Smoke Soak } & \text { fixed } & 2 & 0,1 \\ \text { Liquid Smoke Field } & \text { fixed } & 2 & 0,1 \\ \text { Chamise Smoke } & \text { fixed } & 2 & 0,1 \\ \text { Sulfuric Acid Soak } & \text { fixed } & 2 & 0,1\end{array}$

\begin{tabular}{|c|c|c|c|c|c|}
\hline Source & $\mathrm{DF}$ & Seq SS & Adj SS & Adj MS & F \\
\hline Heat & 1 & 7.37 & 24.75 & 24.75 & 3.83 \\
\hline Charate Soak & 1 & 162.90 & 162.90 & 162.90 & 6.71 \\
\hline Charate Field & 1 & 20.44 & 20.44 & 20.44 & 0.66 \\
\hline Liquid Smoke Soak & 1 & 1162.27 & 1162.27 & 1162.27 & 103.10 \\
\hline Liquid Smoke Field & 1 & 256.44 & 256.44 & 256.44 & 15.44 \\
\hline Chamise Smoke & 1 & 1720.35 & 1720.35 & 1720.35 & 147.73 \\
\hline Sulfuric Acid Soak & 1 & 91.92 & 33.92 & 33.92 & 5.25 \\
\hline Heat*Charate Soak & 1 & 0.39 & 0.39 & 0.39 & 0.02 \\
\hline Heat*Charate Field & 1 & 2.93 & 2.93 & 2.93 & 0.09 \\
\hline Heat*Liquid Smoke Soak & 1 & 3.58 & 3.58 & 3.58 & 0.32 \\
\hline Heat*Liquid Smoke Field & 1 & 12.11 & 12.11 & 12.11 & 0.73 \\
\hline Heat*Chamise Smoke & 1 & 49.83 & 49.83 & 49.83 & 4.28 \\
\hline Heat*Sulfuric Acid Soak & 1 & 6.23 & 6.23 & 6.23 & 0.96 \\
\hline Charate Soak*Liquid Smoke Soak & 1 & 174.59 & 174.59 & 174.59 & 29.10 \\
\hline Charate Soak*Liquid Smoke Field & 1 & 109.15 & 109.15 & 109.15 & 9.23 \\
\hline Charate Soak*Chamise Smoke & 1 & 191.42 & 191.42 & 191.42 & 25.30 \\
\hline Charate Soak*Sulfuric Acid Soak & 1 & 30.86 & 30.86 & 30.86 & 1.34 \\
\hline Charate Field*Liquid Smoke Soak & 1 & 22.81 & 22.81 & 22.81 & 3.79 \\
\hline Charate Field*Liquid Smoke Field & 1 & 30.09 & 30.09 & 30.09 & 2.31 \\
\hline Charate Field*Chamise Smoke & 1 & 22.03 & 22.03 & 22.03 & 3.21 \\
\hline Charate Field*Sulfuric Acid Soak & 1 & 0.01 & 0.01 & 0.01 & 0.00 \\
\hline Liquid Smoke Soak*Sulfuric Acid Soak & 1 & 1.71 & 1.71 & 1.71 & 0.16 \\
\hline $\begin{array}{l}\text { Liquid Smoke Field* } \\
\text { Sulfuric Acid Soak }\end{array}$ & 1 & 3.76 & 3.76 & 3.76 & 0.24 \\
\hline Chamise Smoke*Sulfuric Acid Soak & 1 & 0.00 & 0.00 & 0.00 & 0.00 \\
\hline Error & 119 & 768.23 & 768.23 & 6.46 & \\
\hline Total & 143 & 3493.76 & & & \\
\hline Source & $\mathrm{P}$ & & & & \\
\hline Heat & 0.053 & & & & \\
\hline Charate Soak & 0.010 & & & & \\
\hline Charate Field & 0.419 & & & & \\
\hline Liquid Smoke Soak & 0.000 & & & & \\
\hline Liquid Smoke Field & 0.000 & & & & \\
\hline Chamise Smoke & 0.000 & & & & \\
\hline Sulfuric Acid Soak & 0.024 & & & & \\
\hline Heat*Charate Soak & 0.900 & & & & \\
\hline Heat*Charate Field & 0.760 & & & & \\
\hline Heat*Liquid Smoke Soak & 0.575 & & & & \\
\hline Heat*Liquid Smoke Field & 0.396 & & & & \\
\hline Heat*Chamise Smoke & 0.042 & & & & \\
\hline Heat*Sulfuric Acid Soak & 0.328 & & & & \\
\hline Charate Soak*Liquid Smoke Soak & 0.000 & & & & \\
\hline Charate Soak*Liquid Smoke Field & 0.004 & & & & \\
\hline Charate Soak*Chamise Smoke & 0.000 & & & & \\
\hline Charate Soak*Sulfuric Acid Soak & 0.250 & & & & \\
\hline Charate Field*Liquid Smoke Soak & 0.058 & & & & \\
\hline Charate Field*Liquid Smoke Field & 0.136 & & & & \\
\hline
\end{tabular}




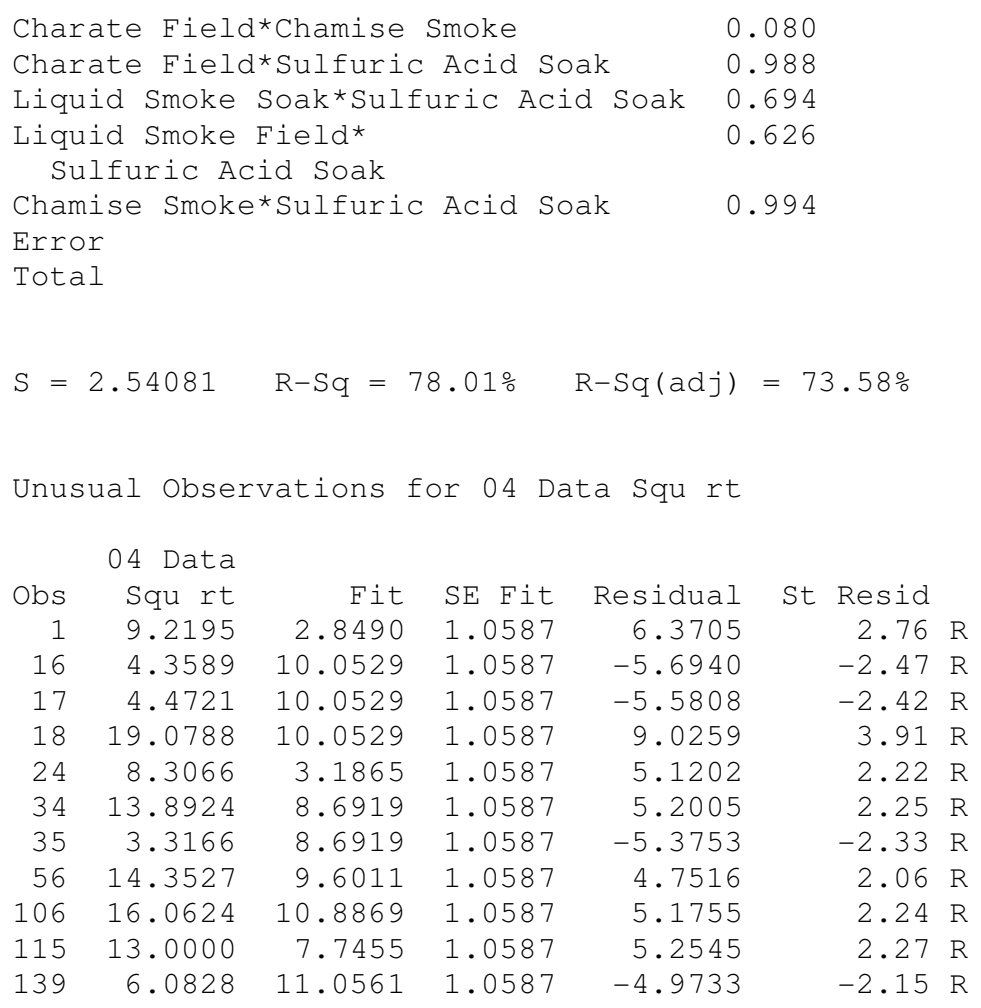

$\mathrm{R}$ denotes an observation with a large standardized residual.

Expected Mean Squares, using Adjusted SS

\section{Source}

1 Heat

Charate Soak

Charate Field

Liquid Smoke Soak

Liquid Smoke Field

Chamise Smoke

Sulfuric Acid Soak

Heat*Charate Soak

Heat*Charate Field

Heat* Liquid Smoke Soak

Heat* Liquid Smoke Field

Heat*Chamise Smoke

Heat*Sulfuric Acid Soak

Charate Soak*Liquid Smoke Soak

Charate Soak*Liquid Smoke Field

Charate Soak*Chamise Smoke

Charate Soak*Sulfuric Acid Soak

Charate Field*Liquid Smoke Soak

Charate Field*Liquid Smoke Field

Charate Field*Chamise Smoke

Charate Field*Sulfuric Acid Soak

Liquid Smoke Soak*Sulfuric Acid Soak

Liquid Smoke Field*

Sulfuric Acid Soak

24 Chamise Smoke*Sulfuric Acid Soak

25 Error

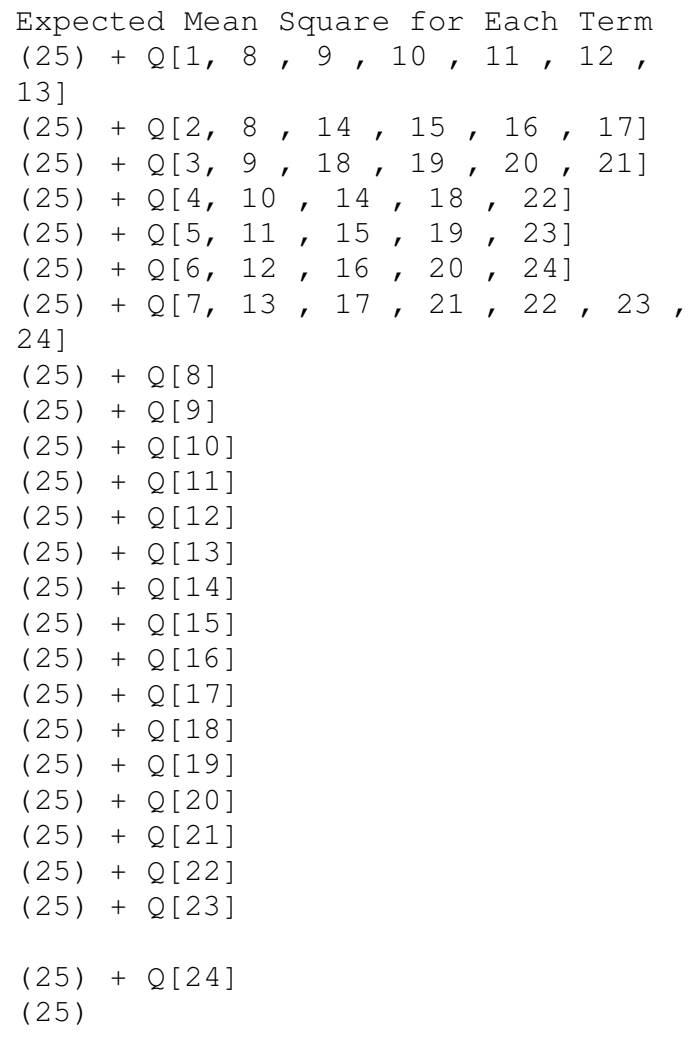


Error Terms for Tests, using Adjusted SS

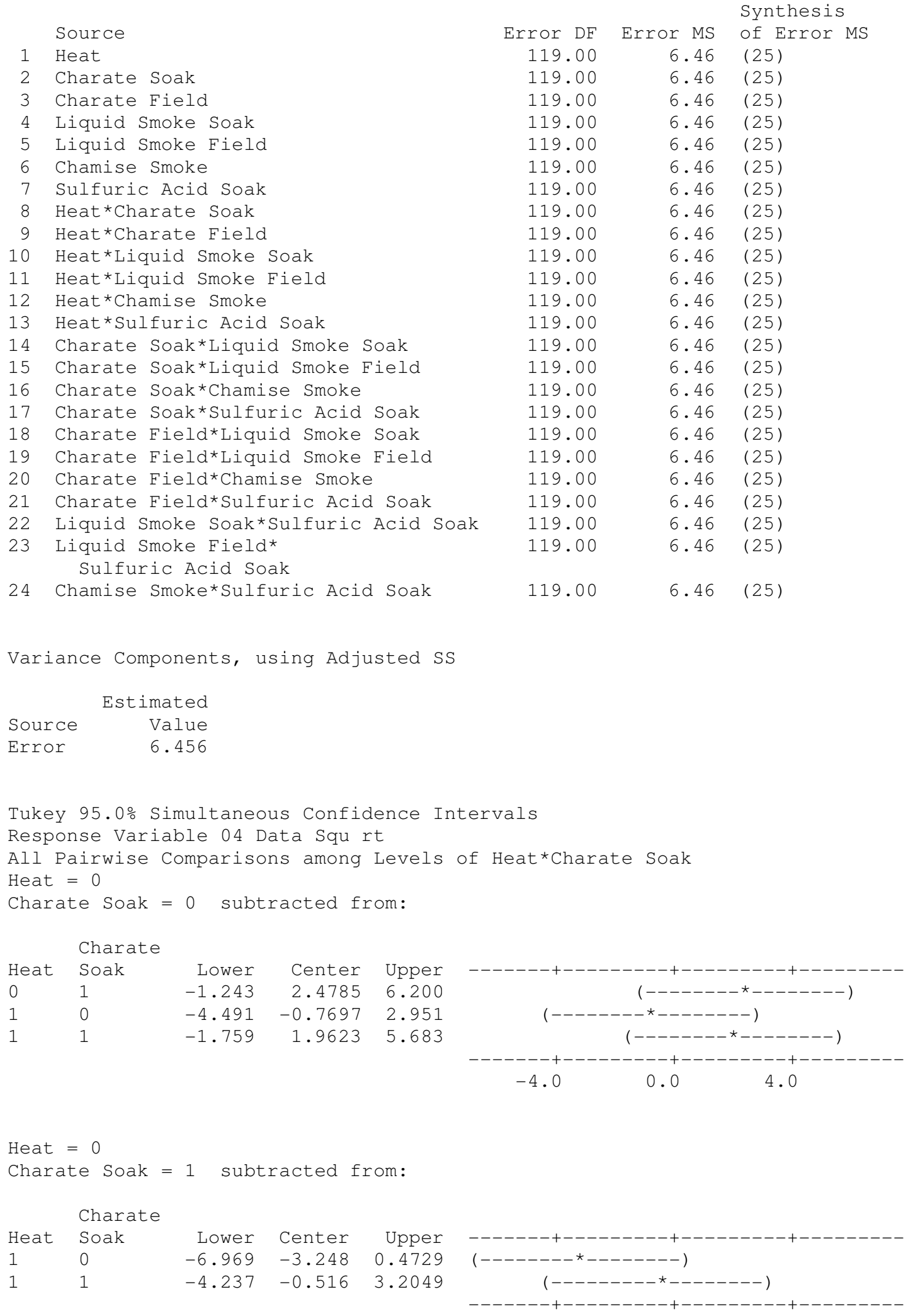




$$
\begin{array}{lll}
-4.0 & 0.0 & 4.0
\end{array}
$$

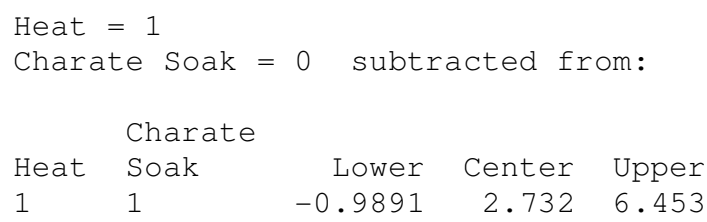

$\begin{array}{lllll}1 & 1 & -0.9891 & 2.732 & 6.453\end{array}$

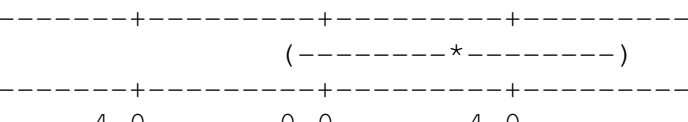

$\begin{array}{lll}-4.0 & 0.0 & 4.0\end{array}$

Tukey Simultaneous Tests

Response Variable 04 Data Squ rt

All Pairwise Comparisons among Levels of Heat*Charate Soak

Heat $=0$

Charate Soak $=0$ subtracted from:

$\begin{array}{llrrrr} & \text { Charate } & \text { Difference } & \text { SE of } & & \text { Adjusted } \\ \text { Heat } & \text { Soak } & \text { of Means } & \text { Difference } & \text { T-Value } & \text { P-Value } \\ 0 & 1 & 2.4785 & 1.422 & 1.7426 & 0.3079 \\ 1 & 0 & -0.7697 & 1.422 & -0.5412 & 0.9487 \\ 1 & 1 & 1.9623 & 1.422 & 1.3797 & 0.5152\end{array}$

Heat $=0$

Charate Soak $=1$ subtracted from:

Charate Difference SE of

Heat Soak of Means Difference

$\begin{array}{llll}1 & 0 & -3.248 & 1.422\end{array}$

$1 \quad 1$

$-0.516$

1.422

T-Value

Adjusted

$-2.284 \quad 0.1093$

$-0.363 \quad 0.9835$

Heat $=1$

Charate Soak $=0$ subtracted from:

$\begin{array}{llrrrr} & \text { Charate } & \text { Difference } & \text { SE of } & & \text { Adjusted } \\ \text { Heat } & \text { Soak } & \text { of Means } & \text { Difference } & \text { T-Value } & \text { P-Value } \\ 1 & 1 & 2.732 & 1.422 & 1.921 & 0.2265\end{array}$

Tukey 95.0\% Simultaneous Confidence Intervals Response Variable 04 Data Squ rt

All Pairwise Comparisons among Levels of Heat*Charate Field

Heat $=0$

Charate Field = 0 subtracted from:

\begin{tabular}{|c|c|c|c|c|}
\hline & $\begin{array}{l}\text { Charat } \\
\text { Field }\end{array}$ & Lower & Center & Upper \\
\hline 0 & 1 & -3.638 & 0.5737 & 4.785 \\
\hline 1 & 0 & -4.981 & -0.7697 & 3.442 \\
\hline 1 & 1 & -3.709 & 0.5025 & 4.71 \\
\hline
\end{tabular}

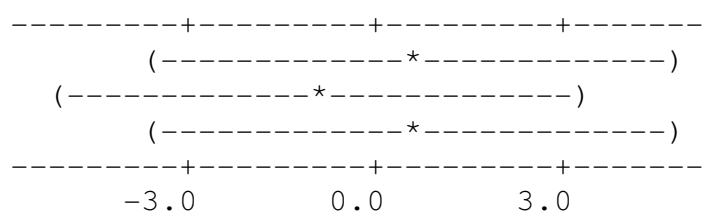

Heat $=0$

Charate Field = 1 subtracted from:

Charate

Heat Field Lower Center Upper 


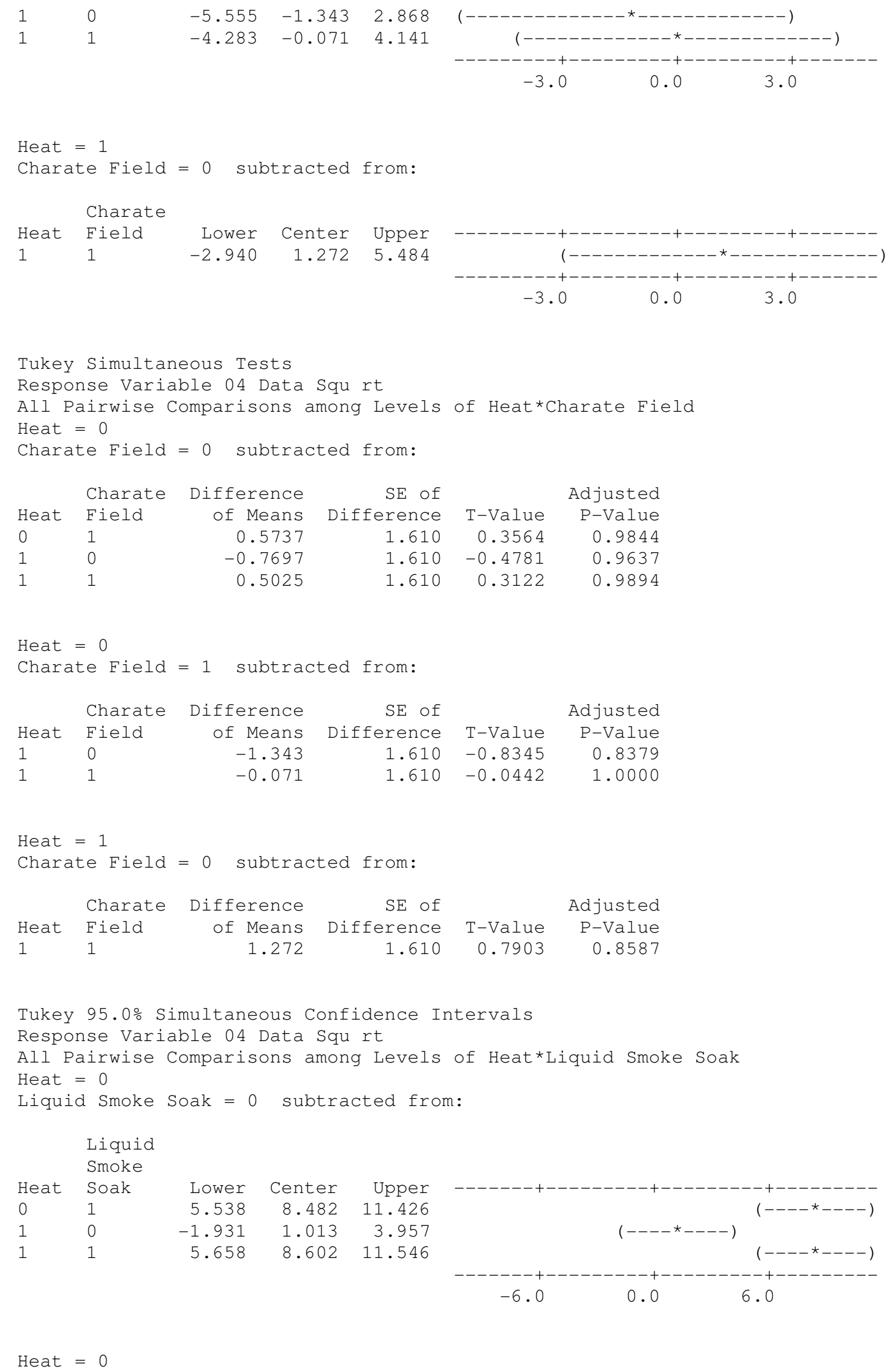




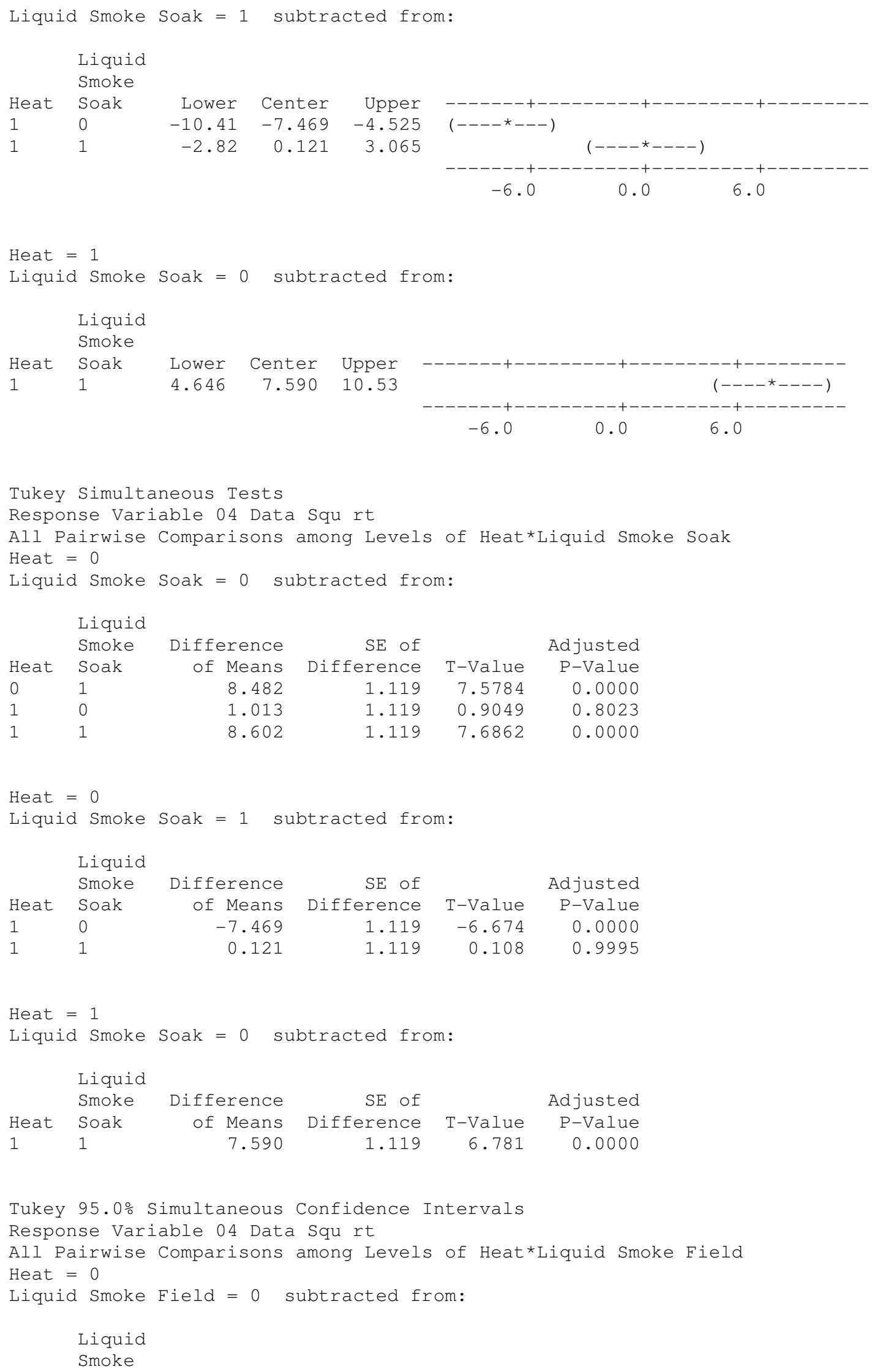




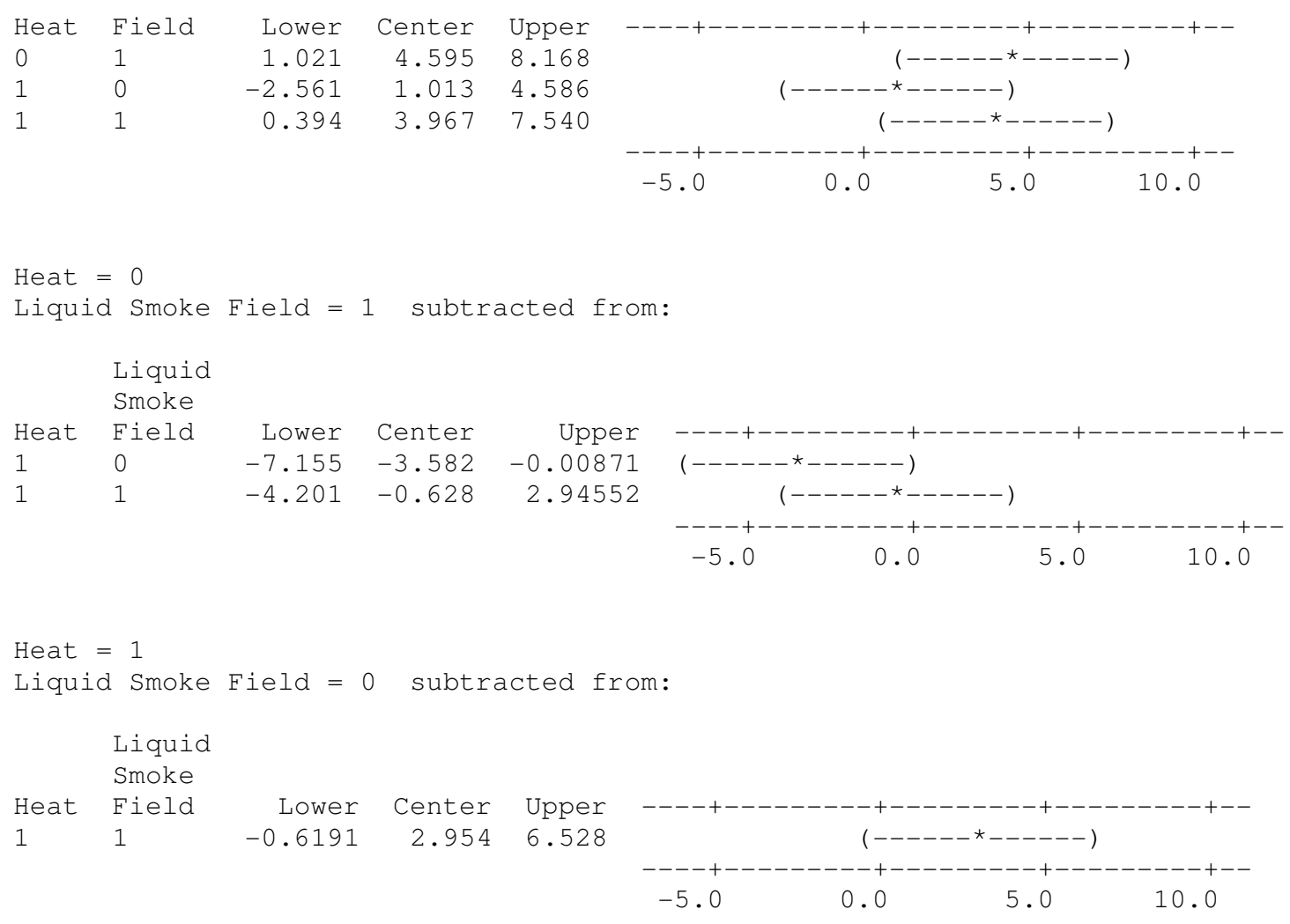

Tukey Simultaneous Tests

Response Variable 04 Data Squ rt

All Pairwise Comparisons among Levels of Heat*Liquid Smoke Field Heat $=0$

Liquid Smoke Field $=0$ subtracted from:

$\begin{array}{llrrrr} & \begin{array}{l}\text { Liquid } \\ \text { Smoke }\end{array} & \text { Difference } & \text { SE of } & & \text { Adjusted } \\ \text { Heat } & \text { Field } & \text { of Means } & \text { Difference } & \text { T-Value } & \text { P-Value } \\ 0 & 1 & 4.595 & 1.358 & 3.3824 & 0.0064 \\ 1 & 0 & 1.013 & 1.358 & 0.7455 & 0.8783 \\ 1 & 1 & 3.967 & 1.358 & 2.9202 & 0.0240\end{array}$

Heat $=0$

Liquid Smoke Field $=1$ subtracted from:

$\begin{array}{llrrrr} & \begin{array}{l}\text { Liquid } \\ \text { Smoke }\end{array} & \text { Difference } & \text { SE of } & & \text { Adjusted } \\ \text { Heat } & \text { Field } & \text { of Means } & \text { Difference } & \text { T-Value } & \text { P-Value } \\ 1 & 0 & -3.582 & 1.358 & -2.637 & 0.0496 \\ 1 & 1 & -0.628 & 1.358 & -0.462 & 0.9670\end{array}$

Heat $=1$

Liquid Smoke Field $=0$ subtracted from:

$\begin{array}{llrrrr} & \text { Liquid } & & & \\ \text { Smoke } & \text { Difference } & \text { SE of } & \text { Adjusted } \\ \text { Heat } & \text { Field } & \text { of Means } & \text { Difference } & \text { T-Value } & \text { P-Value } \\ 1 & 1 & 2.954 & 1.358 & 2.175 & 0.1407\end{array}$




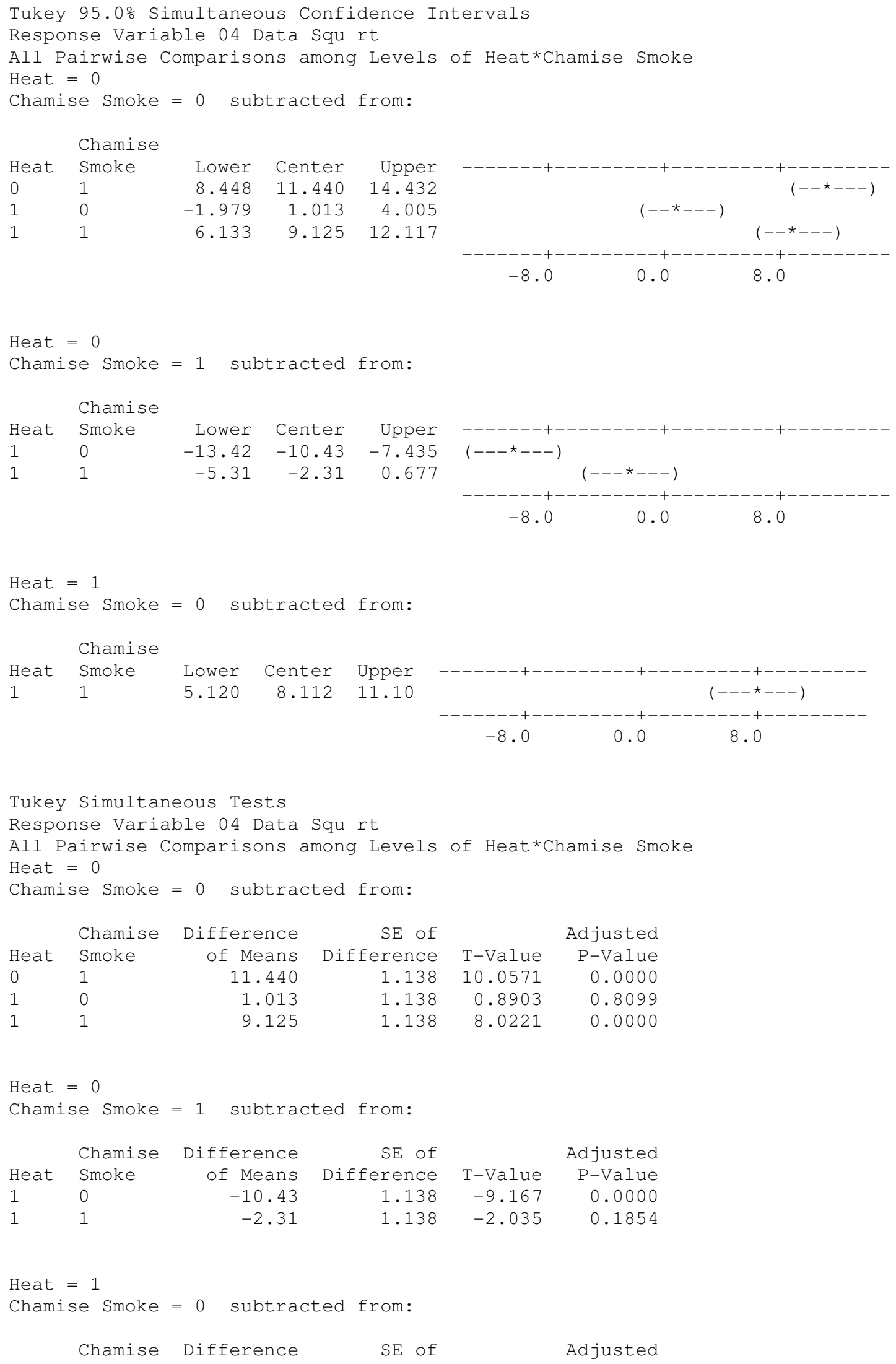

$-8.0$

0.0

8.0

Tukey Simultaneous Tests

Response Variable 04 Data squ rt

All Pairwise Comparisons among Levels of Heat*Chamise Smoke Heat $=0$

Chamise Smoke $=0$ subtracted from:

Chamise Difference SE of Heat Smoke of Means $0 \quad 1$

$1 \quad 0$

11.440

1.013

9.125

Difference

1.138

1.138

1.138

T-Value

10.0571

0.8903

8.0221

Adjusted

P-Value

0.0000

0.8099

0.0000

Heat $=0$

Chamise Smoke $=1$ subtracted from:

$\begin{array}{llrrrr} & \text { Chamise } & \text { Difference } & \text { SE of } & & \text { Adjusted } \\ \text { Heat } & \text { Smoke } & \text { of Means } & \text { Difference } & \text { T-Value } & \text { P-Value } \\ 1 & 0 & -10.43 & 1.138 & -9.167 & 0.0000 \\ 1 & 1 & -2.31 & 1.138 & -2.035 & 0.1854\end{array}$

Heat $=1$

Chamise Smoke = 0 subtracted from:

Chamise Difference SE of

Adjusted 


$\begin{array}{llrrrr}\text { Heat } & \text { Smoke } & \text { of Means } & \text { Difference } & \text { T-Value } & \text { P-Value } \\ 1 & 1 & 8.112 & 1.138 & 7.132 & 0.0000\end{array}$

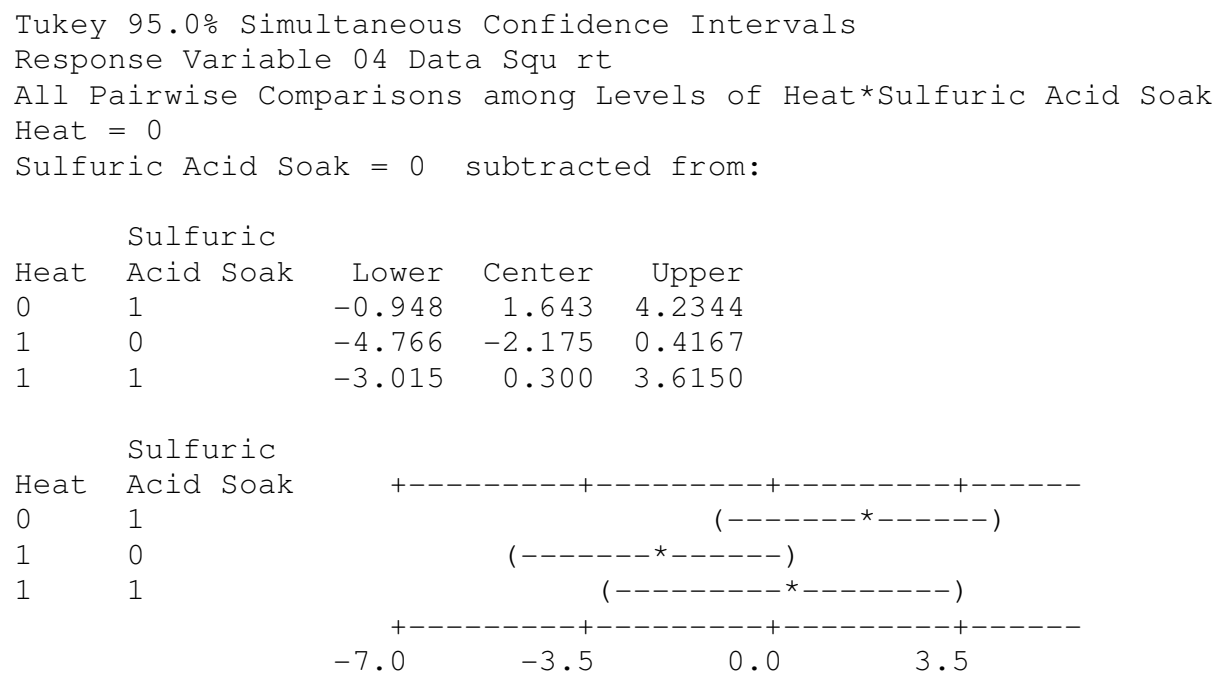




$\begin{array}{rrrrrr}0 & 1 & 1.643 & 0.9931 & 1.655 & 0.3524 \\ 1 & 0 & -2.175 & 0.9931 & -2.190 & 0.1320 \\ 1 & 1 & 0.300 & 1.2704 & 0.236 & 0.9953\end{array}$

Heat $=0$

Sulfuric Acid Soak = 1 subtracted from:

\begin{tabular}{|c|c|c|c|c|c|}
\hline & Sulfuric & Difference & SE of & & Adjusted \\
\hline Heat & Acid Soak & of Means & Difference & T-Value & P-Value \\
\hline 1 & 0 & -3.818 & 1.2704 & -3.005 & 0.0169 \\
\hline 7 & 1 & $-1 \cdot 343$ & 0.9931 & -1.352 & 0.5318 \\
\hline \multicolumn{6}{|c|}{ Heat $=1$} \\
\hline \multicolumn{6}{|c|}{ Sulfuric } \\
\hline & Sulfuric & Difference & SE of & & Adjus \\
\hline leat & Acid Soak & of Means & Difference & T-Value & $\mathrm{P}-\mathrm{Va}$ \\
\hline & 1 & 2.475 & 0.9931 & 2.492 & 0.0 \\
\hline
\end{tabular}

Tukey 95.0\% Simultaneous Confidence Intervals

Response Variable 04 Data Squ rt

All Pairwise Comparisons among Levels of Charate Soak*Liquid Smoke Soak Charate Soak $=0$

Liquid Smoke Soak $=0$ subtracted from:

$\begin{array}{lllrl}\text { Charate } & \begin{array}{l}\text { Liquid } \\ \text { Smoke }\end{array} & & \\ \text { Soak } & \text { Soak } & \text { Lower } & \text { Center } & \text { Upper } \\ 0 & 1 & 8.825 & 11.498 & 14.17 \\ 1 & 0 & 5.345 & 8.017 & 10.69 \\ 1 & 1 & 9.214 & 11.886 & 14.56\end{array}$

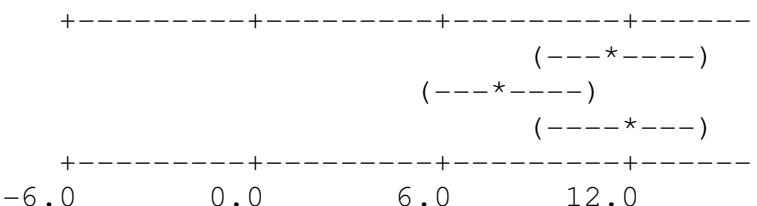

Charate Soak $=0$

Liquid Smoke Soak = 1 subtracted from:

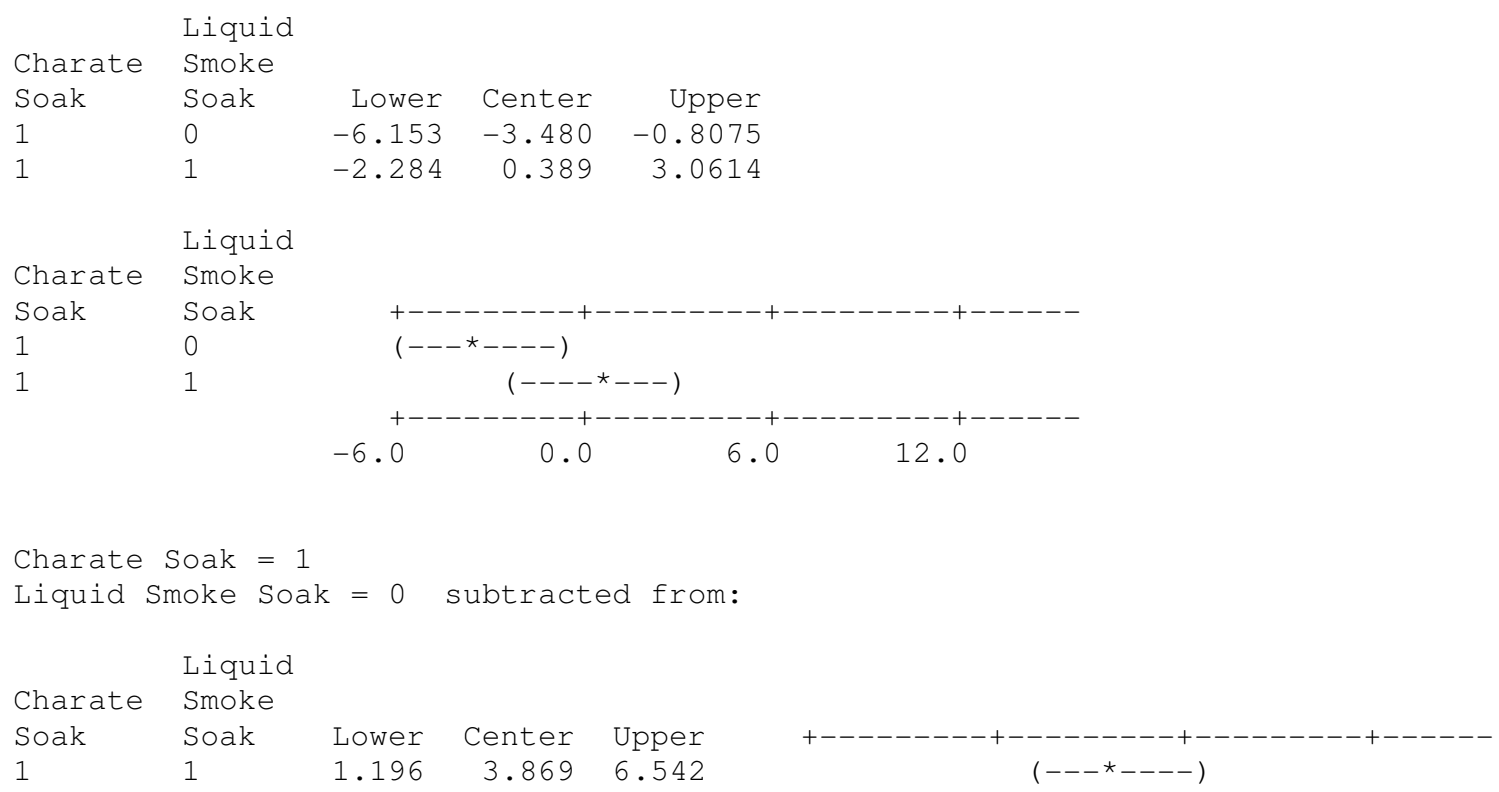




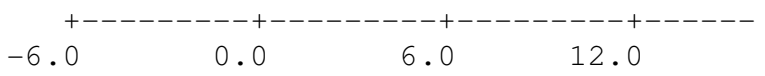

Tukey Simultaneous Tests

Response Variable 04 Data Squ rt

All Pairwise Comparisons among Levels of Charate Soak* Liquid Smoke Soak Charate Soak = 0

Liquid Smoke Soak $=0$ subtracted from:

$\begin{array}{llrrrr} & \text { Liquid } & & & \\ \text { Charate } & \text { Smoke } & \text { Difference } & \text { SE of } & & \text { Adjusted } \\ \text { Soak } & \text { Soak } & \text { Of Means } & \text { Difference } & \text { T-Value } & \text { P-Value } \\ 0 & 1 & 11.498 & 1.000 & 11.498 & 0.0000 \\ 1 & 0 & 8.017 & 1.000 & 8.018 & 0.0000 \\ 1 & 1 & 11.886 & 1.000 & 11.887 & 0.0000\end{array}$

Charate Soak $=0$

Liquid Smoke Soak $=1$ subtracted from:

$\begin{array}{llrrrr} & \text { Liquid } & & & \\ \text { Charate } & \text { Smoke } & \text { Difference } & \text { SE of } & \text { Adjusted } \\ \text { Soak } & \text { Soak } & \text { of Means } & \text { Difference } & \text { T-Value } & \text { P-Value } \\ 1 & 0 & -3.480 & 1.000 & -3.480 & 0.0061 \\ 1 & 1 & 0.389 & 1.000 & 0.389 & 0.9798\end{array}$

Charate Soak $=1$

Liquid Smoke Soak = 0 subtracted from:

$\begin{array}{llrrrr} & \text { Liquid } & & & \\ \text { Charate } & \text { Smoke } & \text { Difference } & \text { SE of } & & \text { Adjusted } \\ \text { Soak } & \text { Soak } & \text { of Means } & \text { Difference } & \text { T-Value } & \text { P-Value } \\ 1 & 1 & 3.869 & 1.000 & 3.869 & 0.0020\end{array}$

Tukey 95.0\% Simultaneous Confidence Intervals Response Variable 04 Data Squ rt

All Pairwise Comparisons among Levels of Charate Soak*Liquid Smoke Field Charate Soak = 0

Liquid Smoke Field $=0$ subtracted from:

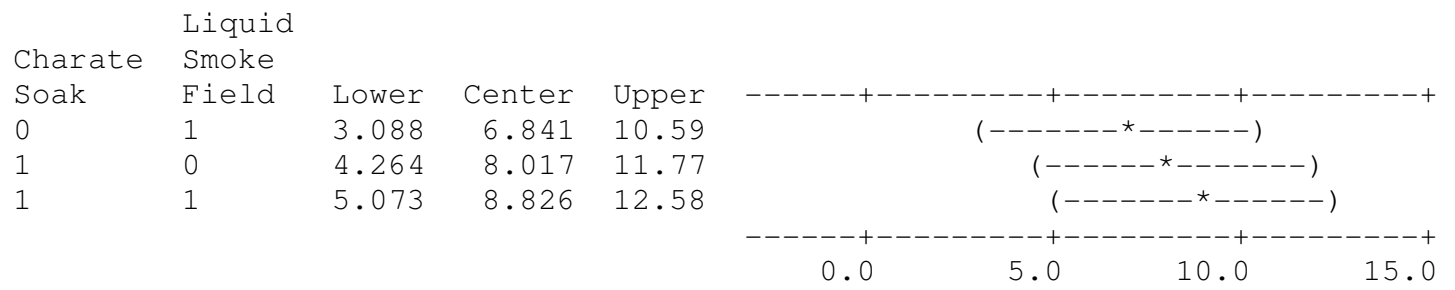

Charate Soak $=0$

Liquid Smoke Field = 1 subtracted from:

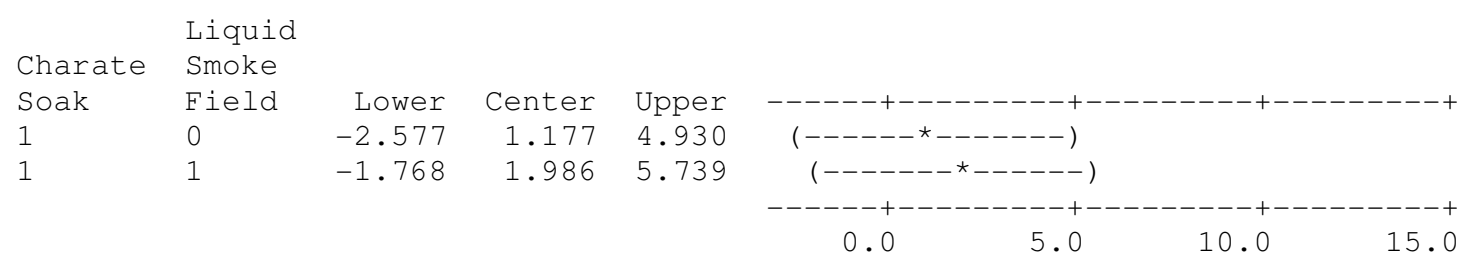




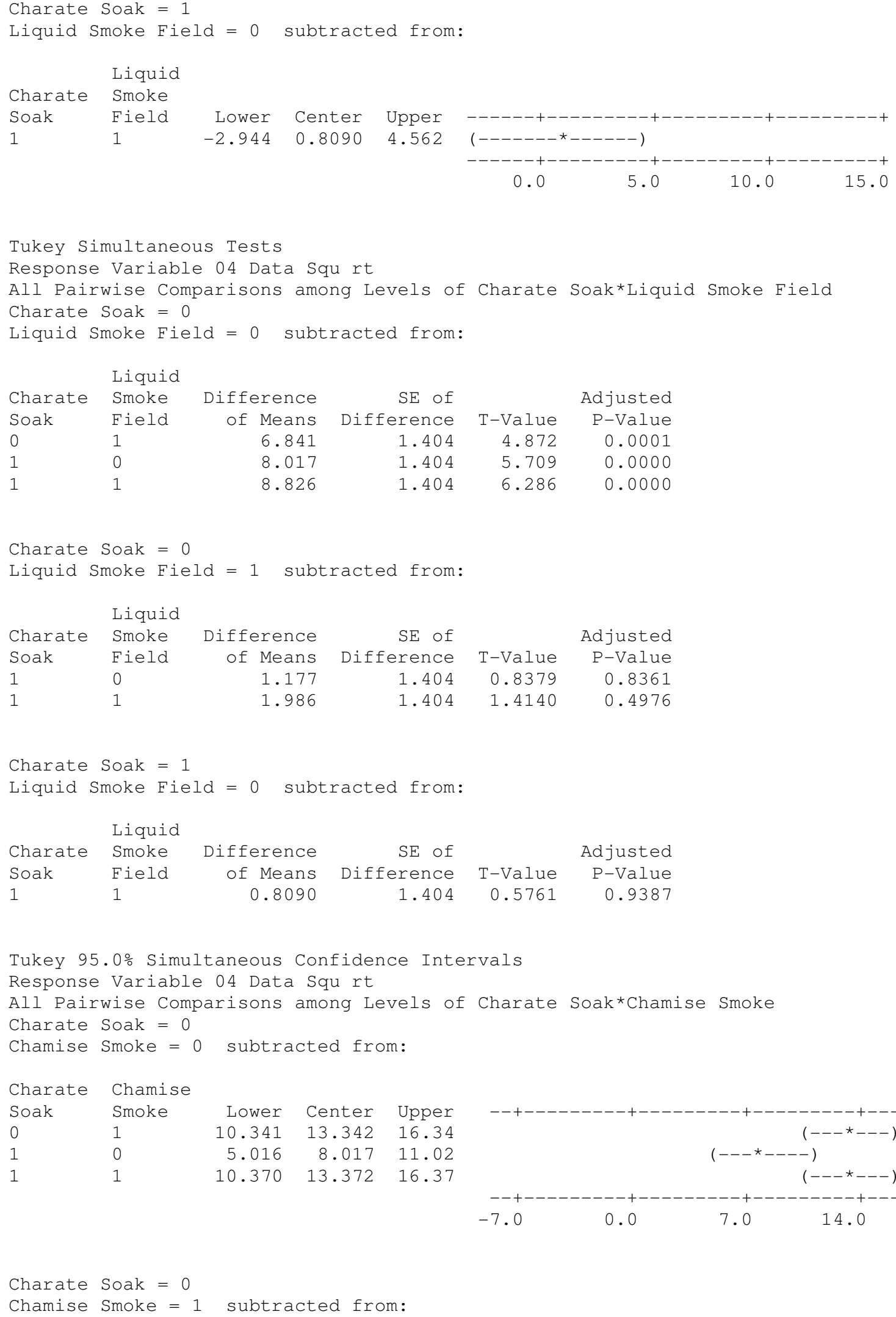




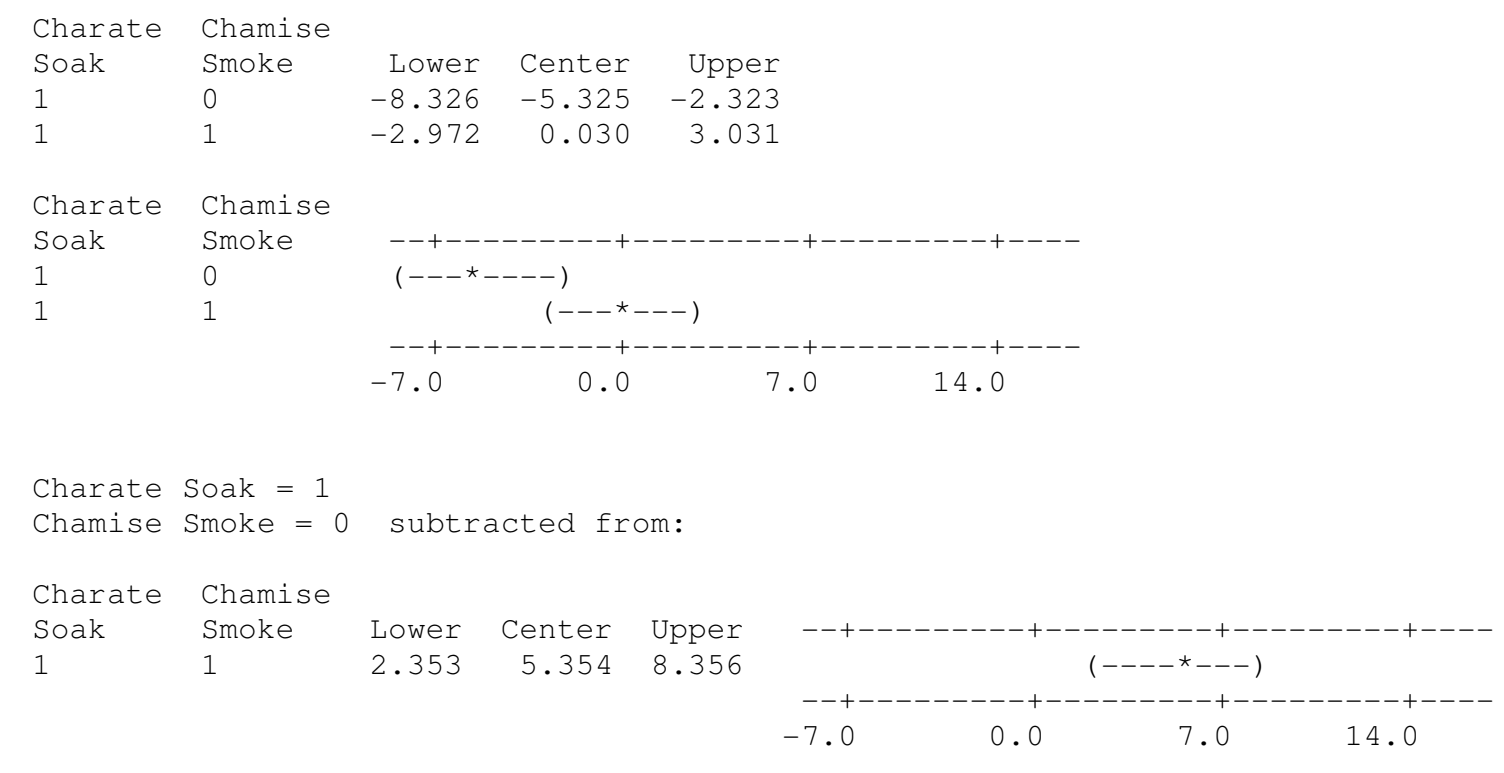

Tukey Simultaneous Tests

Response Variable 04 Data Squ rt

All Pairwise Comparisons among Levels of Charate Soak*Chamise Smoke

Charate $\mathrm{Soak}=0$

Chamise Smoke $=0$ subtracted from:

$\begin{array}{llrrrr}\text { Charate } & \text { Chamise } & \text { Difference } & \text { SE of } & & \text { Adjusted } \\ \text { Soak } & \text { Smoke } & \text { of Means } & \text { Difference } & \text { T-Value } & \text { P-Value } \\ 0 & 1 & 13.342 & 1.123 & 11.881 & 0.0000 \\ 1 & 0 & 8.017 & 1.123 & 7.139 & 0.0000 \\ 1 & 1 & 13.372 & 1.123 & 11.907 & 0.0000\end{array}$

Charate Soak $=0$

Chamise Smoke $=1$ subtracted from:

$\begin{array}{llrrrr}\text { Charate } & \text { Chamise } & \text { Difference } & \text { SE of } & & \text { Adjusted } \\ \text { Soak } & \text { Smoke } & \text { of Means } & \text { Difference } & \text { T-Value } & \text { P-Value } \\ 1 & 0 & -5.325 & 1.123 & -4.742 & 0.0001 \\ 1 & 1 & 0.030 & 1.123 & 0.026 & 1.0000\end{array}$

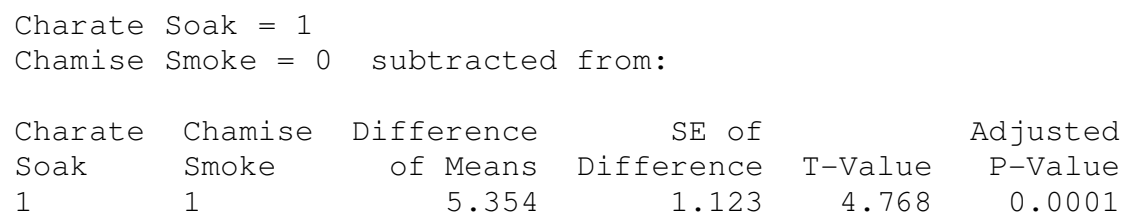

Tukey 95.0\% Simultaneous Confidence Intervals

Response Variable 04 Data Squ rt

All Pairwise Comparisons among Levels of Charate Soak*Sulfuric Acid Soak

Charate $\mathrm{Soak}=0$

Sulfuric Acid Soak = 0 subtracted from:

Charate Sulfuric

Soak Acid Soak Lower Center Upper

$\begin{array}{lllll}0 & 1 & -2.795 & 0.8307 & 4.456\end{array}$ 


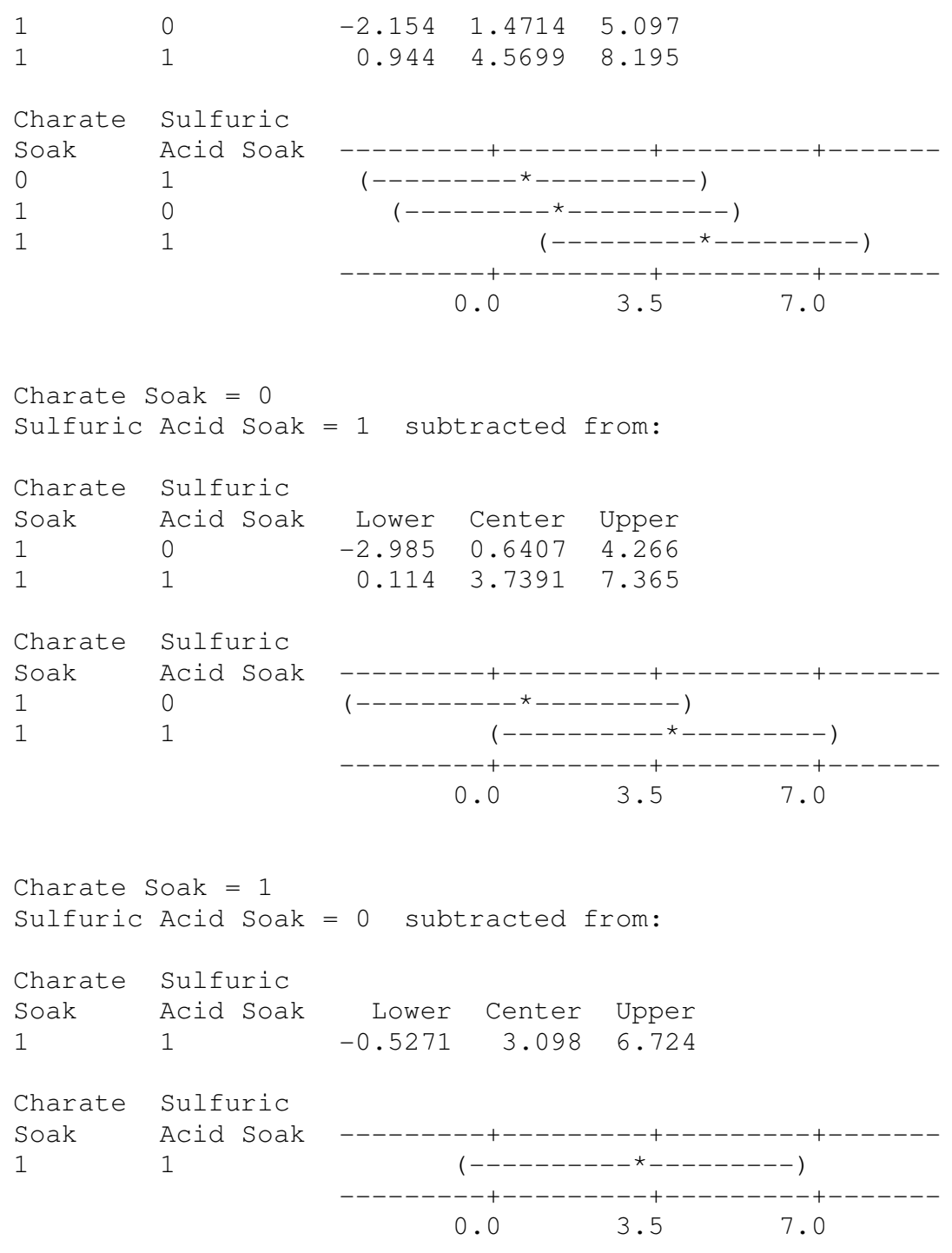

Tukey Simultaneous Tests

Response Variable 04 Data Squ rt

All Pairwise Comparisons among Levels of Charate Soak*Sulfuric Acid Soak Charate Soak $=0$

Sulfuric Acid Soak = 0 subtracted from:

Charate Sulfuric Difference SE of

Soak Acid Soak of Means Difference

$\begin{array}{lllll}0 & 1 & 0.8307 & 1.386 & 0.5995\end{array}$

$\begin{array}{lllll}1 & 0 & 1.4714 & 1.386 & 1.0618\end{array}$

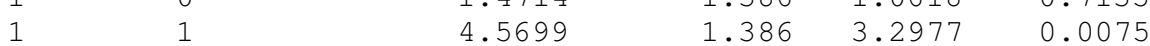

Adjusted

P-Value

0.9320

0.7135

Charate Soak $=0$

Sulfuric Acid Soak = 1 subtracted from:

$\begin{array}{llrrrr}\text { Charate } & \text { Sulfuric } & \text { Difference } & \text { SE of } & & \text { Adjusted } \\ \text { Soak } & \text { Acid Soak } & \text { of Means } & \text { Difference } & \text { T-Value } & \text { P-Value } \\ 1 & 0 & 0.6407 & 1.386 & 0.4623 & 0.9670 \\ 1 & 1 & 3.7391 & 1.386 & 2.6982 & 0.0406\end{array}$




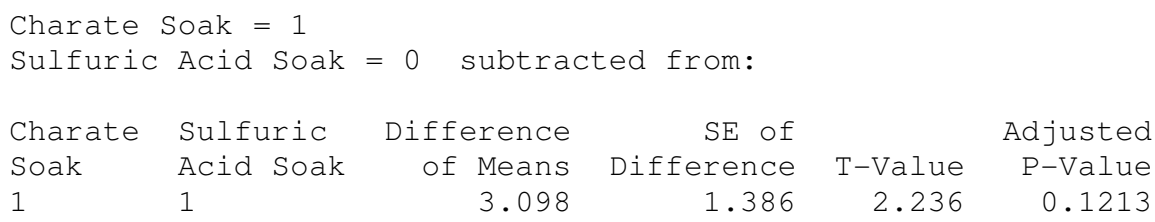

Tukey 95.0\% Simultaneous Confidence Intervals

Response Variable 04 Data Squ rt

All Pairwise Comparisons among Levels of Charate FieldLiquid Smoke Soak

Charate Field = 0

Liquid Smoke Soak = 0 subtracted from:

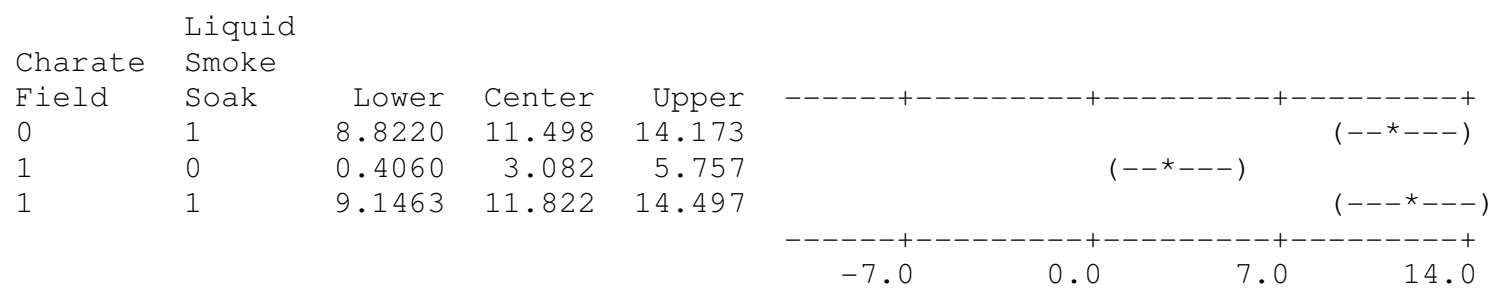

Charate Field $=0$

Liquid Smoke Soak = 1 subtracted from:

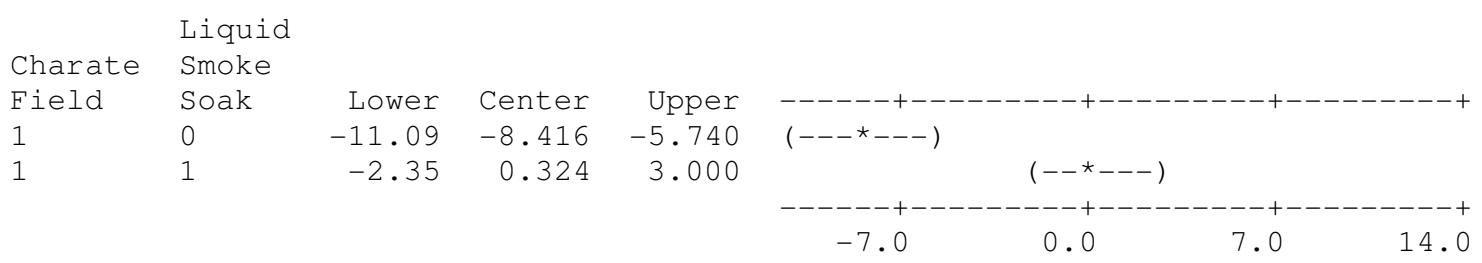

Charate Field $=1$

Liquid Smoke Soak $=0$ subtracted from:

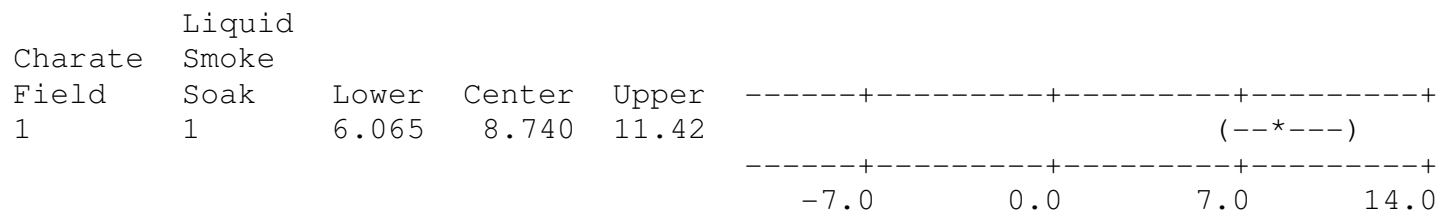

Tukey Simultaneous Tests

Response Variable 04 Data Squ rt

All Pairwise Comparisons among Levels of Charate Field*Liquid Smoke Soak Charate Field = 0

Liquid Smoke Soak $=0$ subtracted from:

$\begin{array}{llrrrr} & \text { Liquid } & & & \\ \text { Charate } & \text { Smoke } & \text { Difference } & \text { SE of } & & \text { Adjusted } \\ \text { Field } & \text { Soak } & \text { of Means } & \text { Difference } & \text { T-Value } & \text { P-Value } \\ 0 & 1 & 11.498 & 1.001 & 11.486 & 0.0000 \\ 1 & 0 & 3.082 & 1.001 & 3.078 & 0.0181 \\ 1 & 1 & 11.822 & 1.001 & 11.810 & 0.0000\end{array}$

Charate Field $=0$ 


Liquid Smoke Soak $=1$ subtracted from:
$\begin{array}{llrrrr}\text { Liquid } \\ \text { Charate } & \text { Smoke } & \text { Difference } & \text { SE of } & & \text { Adjusted } \\ \text { Field } & \text { Soak } & \text { of Means } & \text { Difference } & \text { T-Value } & \text { P-Value } \\ 1 & 0 & -8.416 & 1.001 & -8.407 & 0.0000 \\ 1 & 1 & 0.324 & 1.001 & 0.324 & 0.9881\end{array}$

Charate Field $=1$

Liquid Smoke Soak $=0$ subtracted from:

$\begin{array}{llrrrr} & \text { Liquid } & & & \\ \text { Charate } & \text { Smoke } & \text { Difference } & \text { SE of } & & \text { Adjusted } \\ \text { Field } & \text { Soak } & \text { of Means } & \text { Difference } & \text { T-Value } & \text { P-Value } \\ 1 & 1 & 8.740 & 1.001 & 8.731 & 0.0000\end{array}$

Tukey 95.0\% Simultaneous Confidence Intervals Response Variable 04 Data Squ rt

All Pairwise Comparisons among Levels of Charate Field*Liquid Smoke Field Charate Field = 0

Liquid Smoke Field = 0 subtracted from:

\begin{tabular}{|c|c|c|c|c|}
\hline & Liquid & & & \\
\hline Charate & Smoke & & & \\
\hline Field & Field & Lower & Center & Upper \\
\hline 0 & 1 & 2.9025 & 6.841 & 10.779 \\
\hline 1 & 0 & -0.8567 & 3.082 & 7.020 \\
\hline 1 & 1 & 2.8169 & 6.755 & 10.694 \\
\hline & Liquid & & & \\
\hline Charate & Smoke & & & \\
\hline Field & Field & ---+ & -- & ---------+----------+- \\
\hline 0 & 1 & & & $(-------\star--------)$ \\
\hline 1 & 0 & & $(--$ & $-----\star-------)$ \\
\hline 1 & 1 & & & $(-------\star------)$ \\
\hline & & ---+- & $\begin{array}{r}---++ \\
0.0\end{array}$ & $\begin{array}{cc}5.0 & 10.0\end{array}$ \\
\hline
\end{tabular}

Charate Field $=0$

Liquid Smoke Field $=1$ subtracted from:

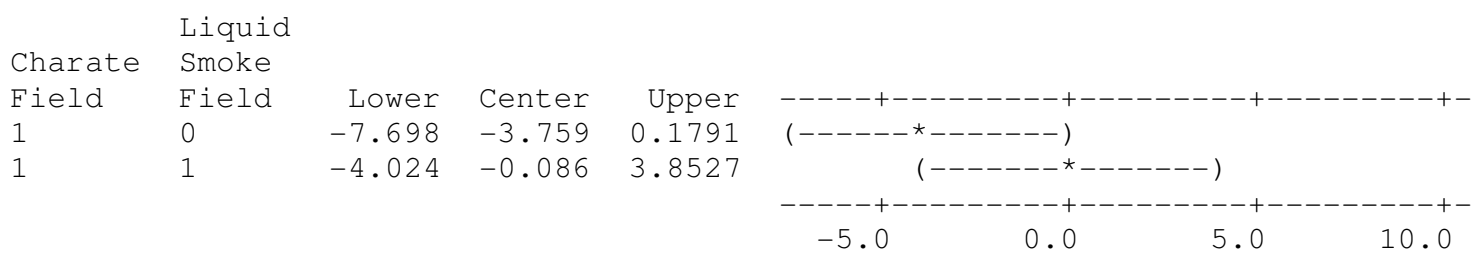

Charate Field $=1$

Liquid Smoke Field $=0$ subtracted from:

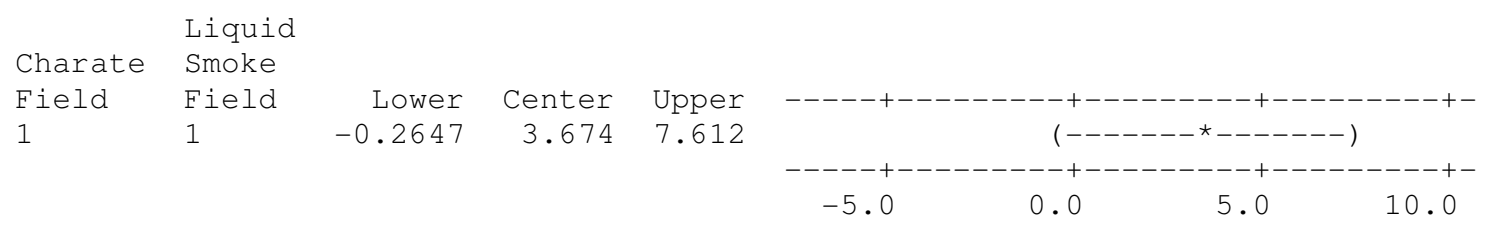


Tukey Simultaneous Tests

Response Variable 04 Data Squ rt

All Pairwise Comparisons among Levels of Charate Field*Liquid Smoke Field Charate Field = 0

Liquid Smoke Field = 0 subtracted from:

$\begin{array}{llrrrr} & \text { Liquid } & & & \\ \text { Charate } & \text { Smoke } & \text { Difference } & \text { SE of } & & \text { Adjusted } \\ \text { Field } & \text { Field } & \text { of Means } & \text { Difference } & \text { T-Value } & \text { P-Value } \\ 0 & 1 & 6.841 & 1.473 & 4.643 & 0.0002 \\ 1 & 0 & 3.082 & 1.473 & 2.091 & 0.1718 \\ 1 & 1 & 6.755 & 1.473 & 4.585 & 0.0002\end{array}$
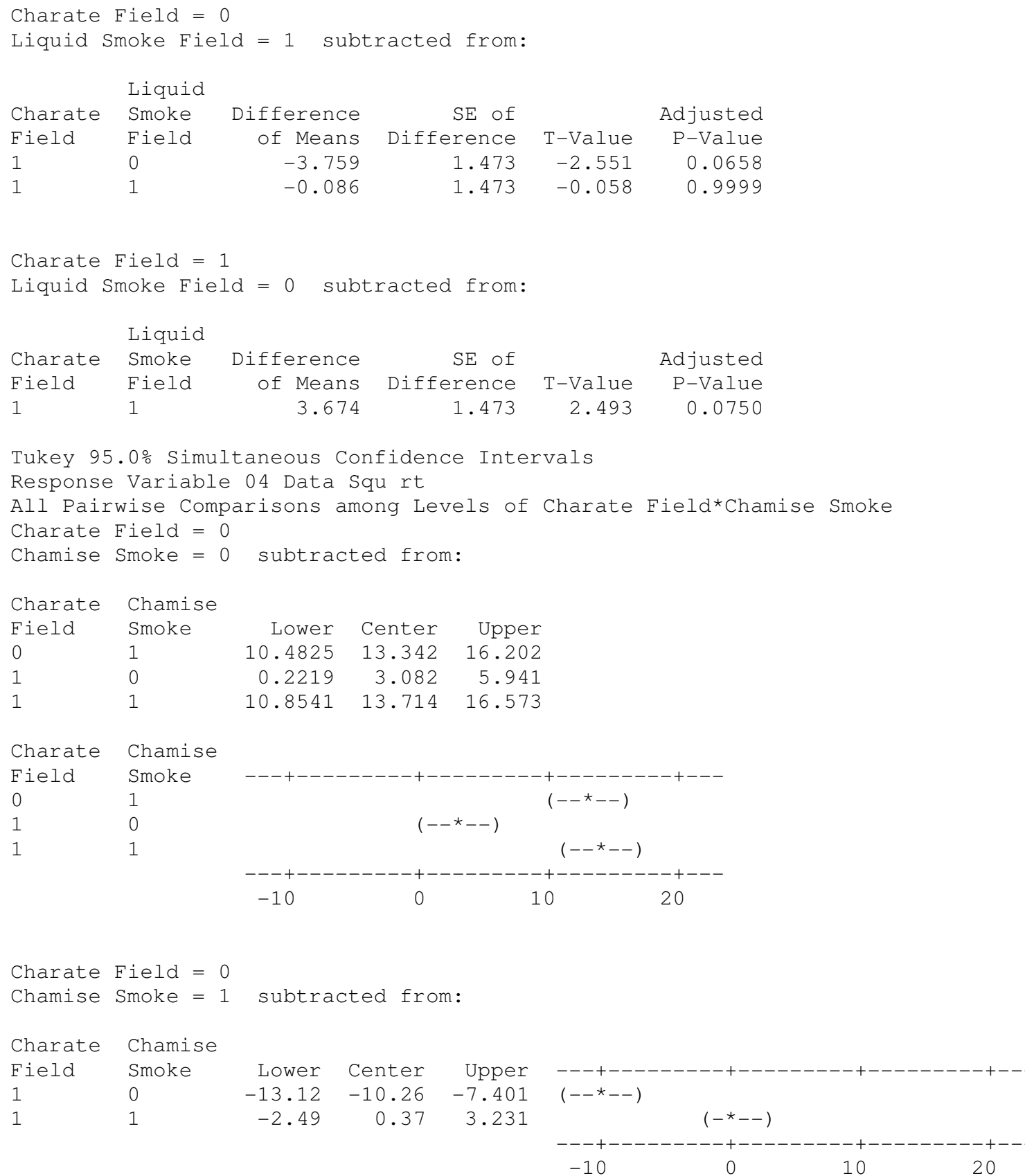

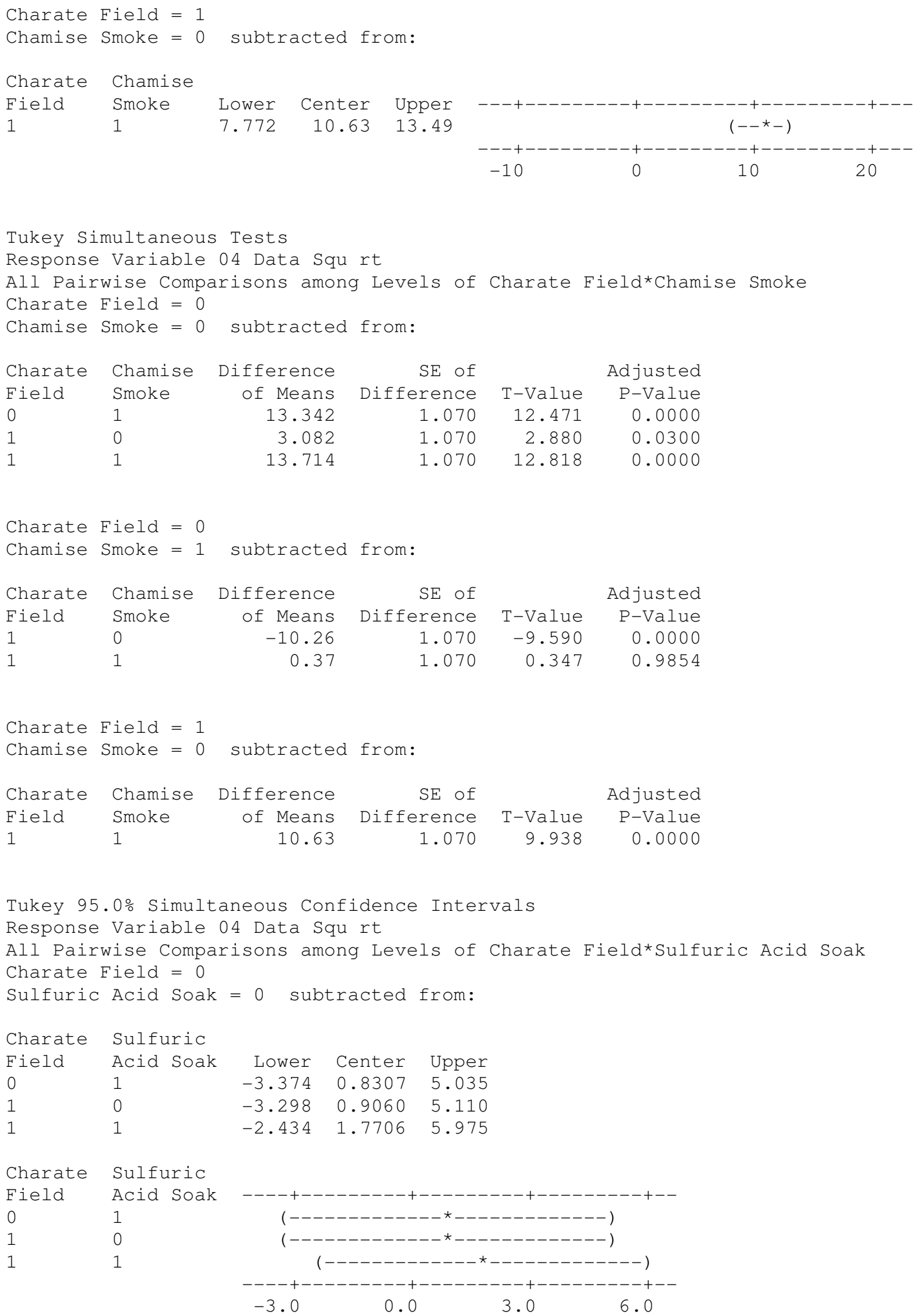


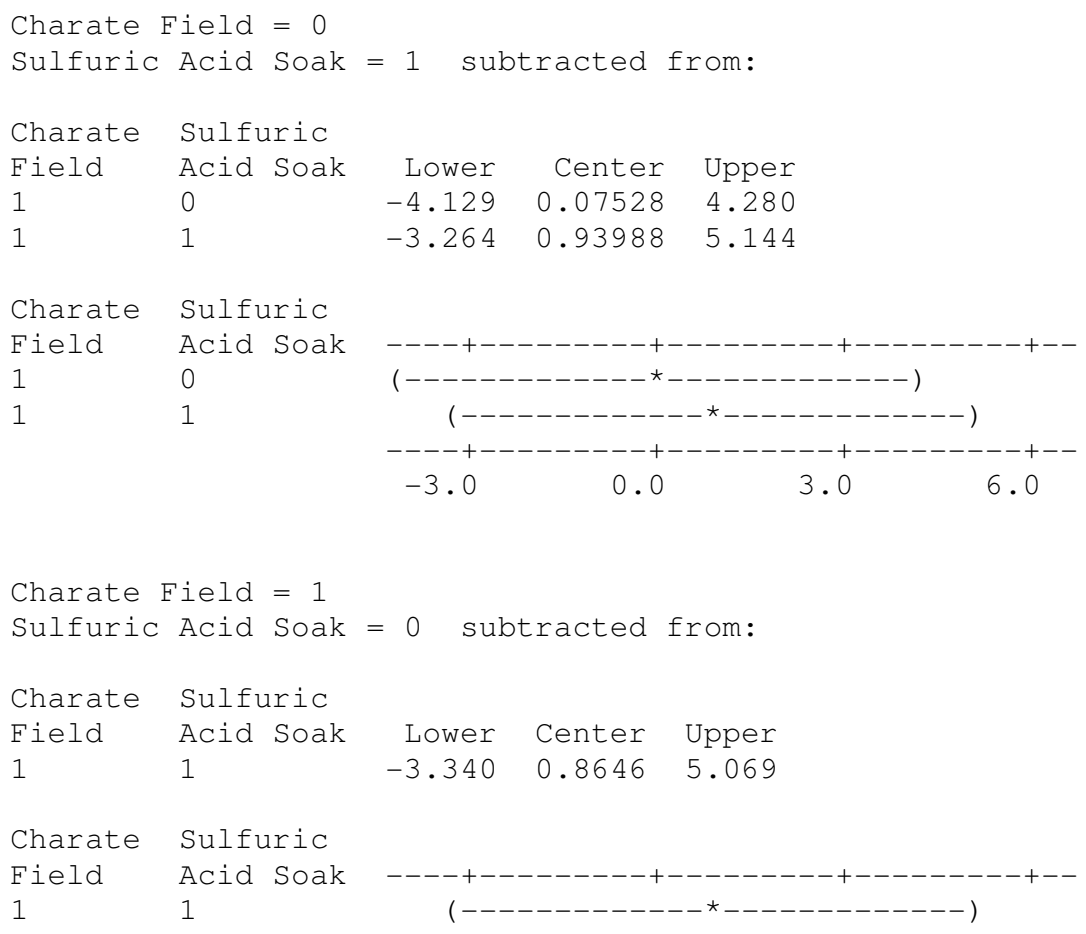

Tukey Simultaneous Tests

Response Variable 04 Data Squ rt

All Pairwise Comparisons among Levels of Charate Field*Sulfuric Acid Soak Charate Field $=0$ 


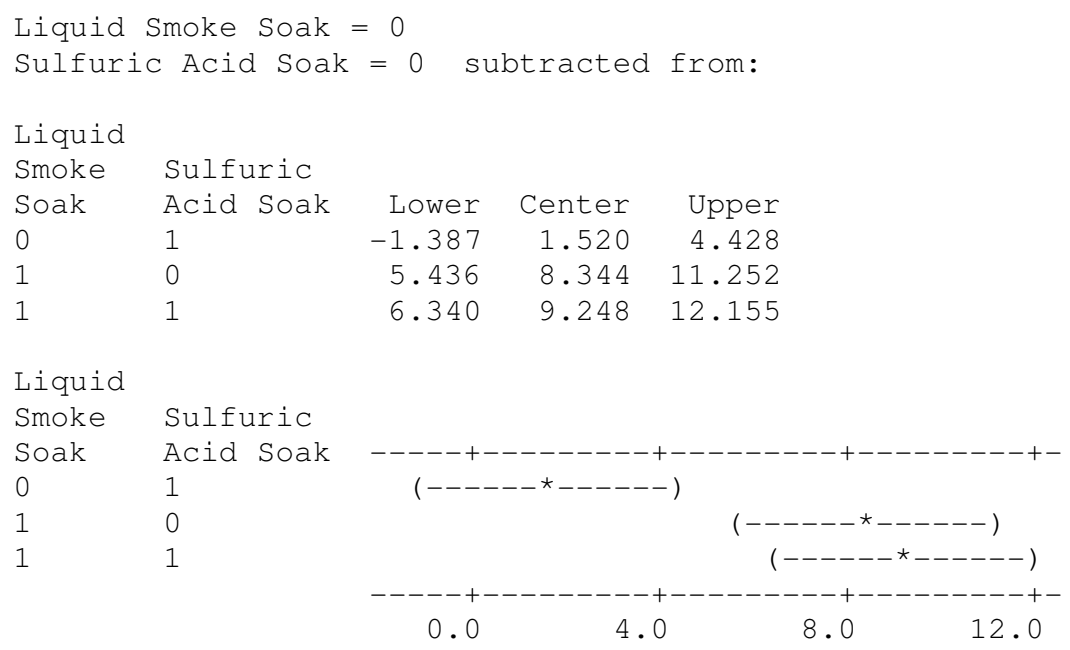

Liquid Smoke Soak $=0$

Sulfuric Acid Soak = 1 subtracted from:

Liquid

Smoke Sulfuric

Soak Acid Soak Lower Center Upper

$\begin{array}{lllll}1 & 0 & 3.916 & 6.824 & 9.731\end{array}$

$\begin{array}{lllll}1 & 1 & 4.819 & 7.727 & 10.635\end{array}$

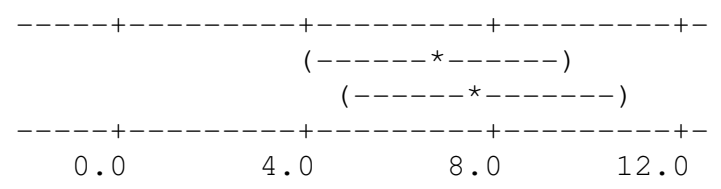

Liquid Smoke Soak $=1$

Sulfuric Acid Soak = 0 subtracted from:

Liquid

Smoke Sulfuric

Soak Acid Soak

1

1

$\begin{array}{rrr}\text { Lower } & \text { Center } & \text { Upper } \\ -2.004 & 0.9036 & 3.811\end{array}$

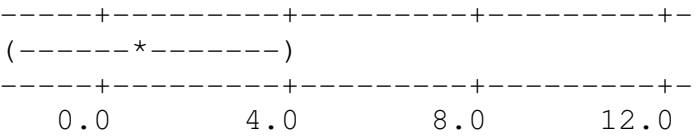

Tukey Simultaneous Tests

Response Variable 04 Data Squ rt

All Pairwise Comparisons among Levels of Liquid Smoke Soak*Sulfuric Acid Soak Liquid Smoke Soak $=0$

Sulfuric Acid Soak = 0 subtracted from:

\begin{tabular}{llrrrr} 
Liquid & \multicolumn{5}{c}{} \\
Smoke & Sulfuric & Difference & SE of & & Adjusted \\
Soak & Acid Soak & of Means & Difference & T-Value & P-Value \\
0 & 1 & 1.520 & 1.105 & 1.376 & 0.5189 \\
1 & 0 & 8.344 & 1.105 & 7.549 & 0.0000 \\
1 & 1 & 9.248 & 1.105 & 8.366 & 0.0000
\end{tabular}

Liquid Smoke Soak $=0$

Sulfuric Acid Soak = 1 subtracted from:

$\begin{array}{llrlrl}\text { Liquid } & & & & \\ \text { Smoke } & \text { Sulfuric } & \text { Difference } & \text { SE of } & & \text { Adjusted } \\ \text { Soak } & \text { Acid Soak } & \text { of Means } & \text { Difference } & \text { T-Value } & \text { P-Value }\end{array}$ 


\begin{tabular}{|c|c|c|c|c|c|}
\hline 1 & 0 & 6.824 & 1.105 & 6.173 & 0.0000 \\
\hline 1 & 1 & 7.727 & 1.105 & 6.990 & 0.0000 \\
\hline $\begin{array}{l}\text { Liquid } \\
\text { Sulfuri }\end{array}$ & $\begin{array}{l}\text { Smoke Soak } \\
\text { c Acid Soak }\end{array}$ & $\begin{array}{l}=1 \\
=0\end{array}$ & cted from: & & \\
\hline Liquid & & & & & \\
\hline Smoke & Sulfuric & Difference & $S E$ of & & Adjusted \\
\hline Soak & Acid Soak & of Means & Difference & T-Value & P-Value \\
\hline 1 & 1 & 0.9036 & 1.105 & 0.8174 & 0.8460 \\
\hline
\end{tabular}

Tukey 95.0\% Simultaneous Confidence Intervals

Response Variable 04 Data Squ rt

All Pairwise Comparisons among Levels of Liquid Smoke Field*Sulfuric Acid Soak Liquid Smoke Field $=0$

Sulfuric Acid Soak = 0 subtracted from:

Liquid

Smoke Sulfuric

Field Acid Soak

0

10

$1 \quad 1$

$\begin{array}{rr}\text { Lower } & \text { Center } \\ -1.954 & 1.520 \\ -0.158 & 3.317 \\ 2.277 & 5.752\end{array}$

Upper

4.995

6.792

9.227

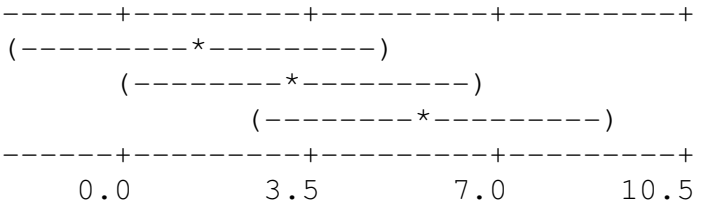

Liquid Smoke Field $=0$

Sulfuric Acid Soak $=1$ subtracted from:
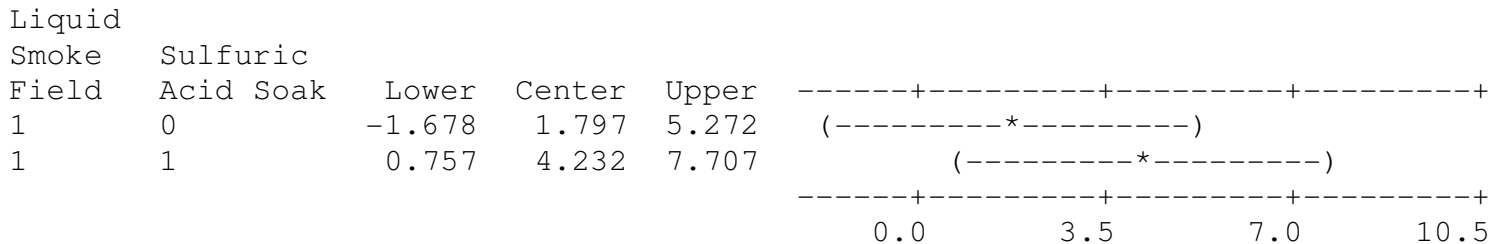

Liquid Smoke Field $=1$

Sulfuric Acid Soak = 0 subtracted from:

Liquid

Smoke Sulfuric

Field Acid Soak Lower Center Upper

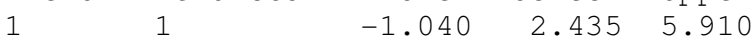

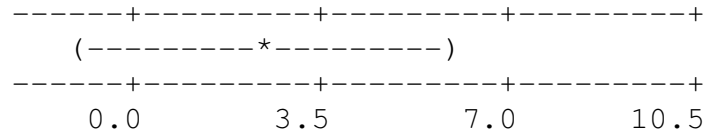

Tukey Simultaneous Tests

Response Variable 04 Data Squ rt

All Pairwise Comparisons among Levels of Liquid Smoke Field*Sulfuric Acid Soak Liquid Smoke Field $=0$

Sulfuric Acid Soak = 0 subtracted from:

Liquid

Smoke

Field

Sulfuric

Difference

of Means

1.520

$\begin{array}{llllll}1 & 0 & 3.317 & 1.321 & 2.511 & 0.0671\end{array}$

SE of
Difference
1.321
1.321

T-Value

Adjusted

1

$\begin{array}{llllll}1 & 0 & 3.317 & 1.321 & 2.511 & 0.0671\end{array}$

-Value

0.6595 


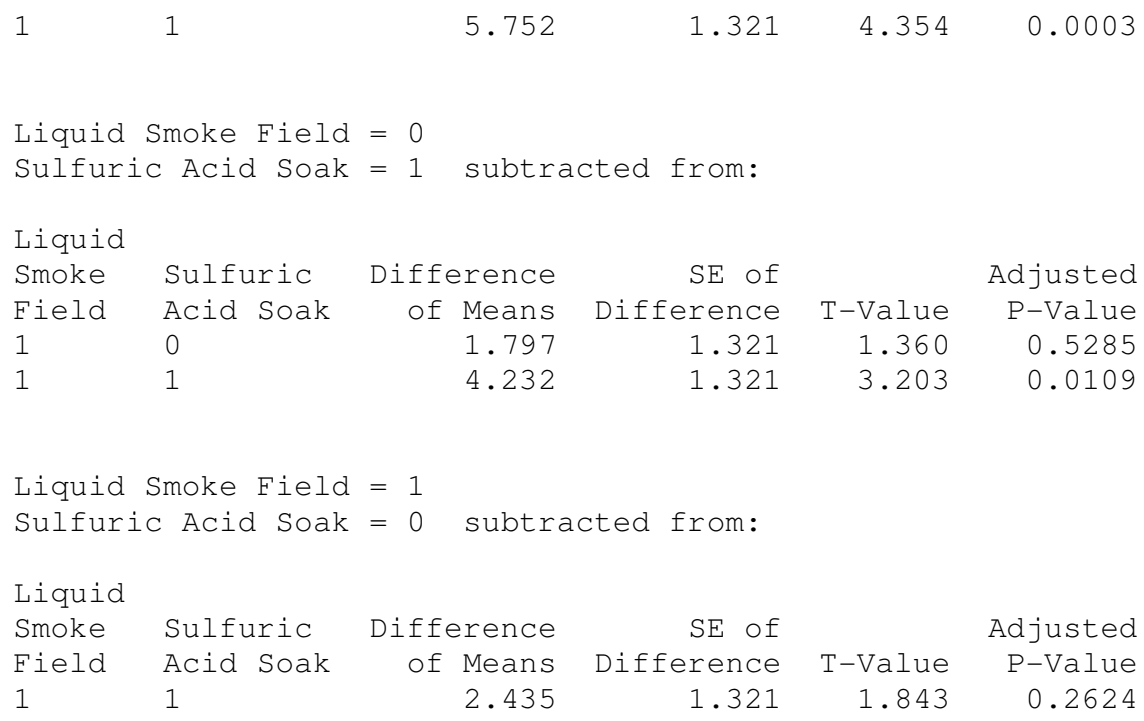

$4.232 \quad 1.321$

3.203

0.5285

0.0109

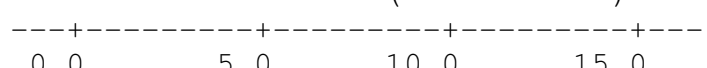

$\begin{array}{llll}0.0 & 5.0 & 10.0 & 15.0\end{array}$

Chamise Smoke $=0$

Sulfuric Acid Soak = 1 subtracted from:

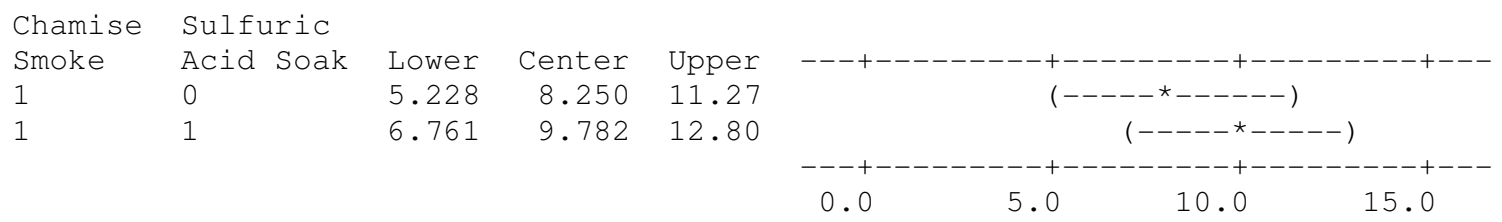

Chamise Smoke $=1$

Sulfuric Acid Soak = 0 subtracted from:

Chamise Sulfuric

Smoke Acid Soak Lower Center Upper

$\begin{array}{lllll}1 & 1 & -1.488 & 1.533 & 4.554\end{array}$

Chamise Sulfuric

Smoke Acid Soak 


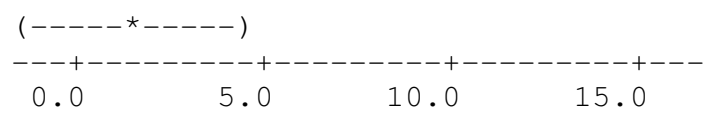

Tukey Simultaneous Tests

Response Variable 04 Data Squ rt

All Pairwise Comparisons among Levels of Chamise Smoke*Sulfuric Acid Soak Chamise Smoke $=0$

Sulfuric Acid Soak = 0 subtracted from:

$\begin{array}{llrrrr}\text { Chamise } & \text { Sulfuric } & \text { Difference } & \text { SE of } & & \text { Adjusted } \\ \text { Smoke } & \text { Acid Soak } & \text { of Means } & \text { Difference } & \text { T-Value } & \text { P-Value } \\ 0 & 1 & 1.520 & 1.149 & 1.324 & 0.5512 \\ 1 & 0 & 9.770 & 1.149 & 8.506 & 0.0000 \\ 1 & 1 & 11.303 & 1.149 & 9.841 & 0.0000\end{array}$

Chamise Smoke $=0$

Sulfuric Acid Soak = 1 subtracted from:

$\begin{array}{llrrrr}\text { Chamise } & \text { Sulfuric } & \text { Difference } & \text { SE of } & & \text { Adjusted } \\ \text { Smoke } & \text { Acid Soak } & \text { of Means } & \text { Difference } & \text { T-Value } & \text { P-Value } \\ 1 & 0 & 8.250 & 1.149 & 7.182 & 0.0000 \\ 1 & 1 & 9.782 & 1.149 & 8.517 & 0.0000\end{array}$

Chamise Smoke $=1$

Sulfuric Acid Soak = 0 subtracted from:

$\begin{array}{llrrrr}\text { Chamise } & \text { Sulfuric } & \text { Difference } & \text { SE of } & & \text { Adjusted } \\ \text { Smoke } & \text { Acid Soak } & \text { of Means } & \text { Difference } & \text { T-Value } & \text { P-Value } \\ 1 & 1 & 1.533 & 1.149 & 1.335 & 0.5445\end{array}$




\section{APPENDIX C: Interval Plots Using All Data}




\section{Charate Soak}
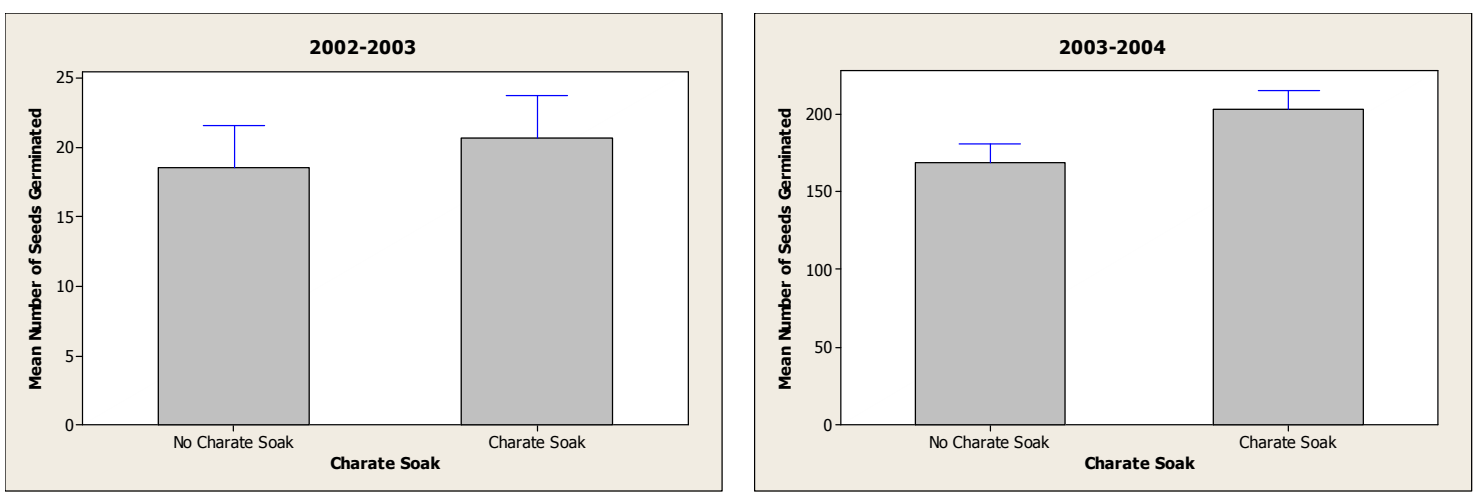

Figures C-1A and 1B. Comparison of Seeds Germinated Without and With Charate Soak Using All Data. Error bars represent the standard error of the mean.

\section{Charate Field}
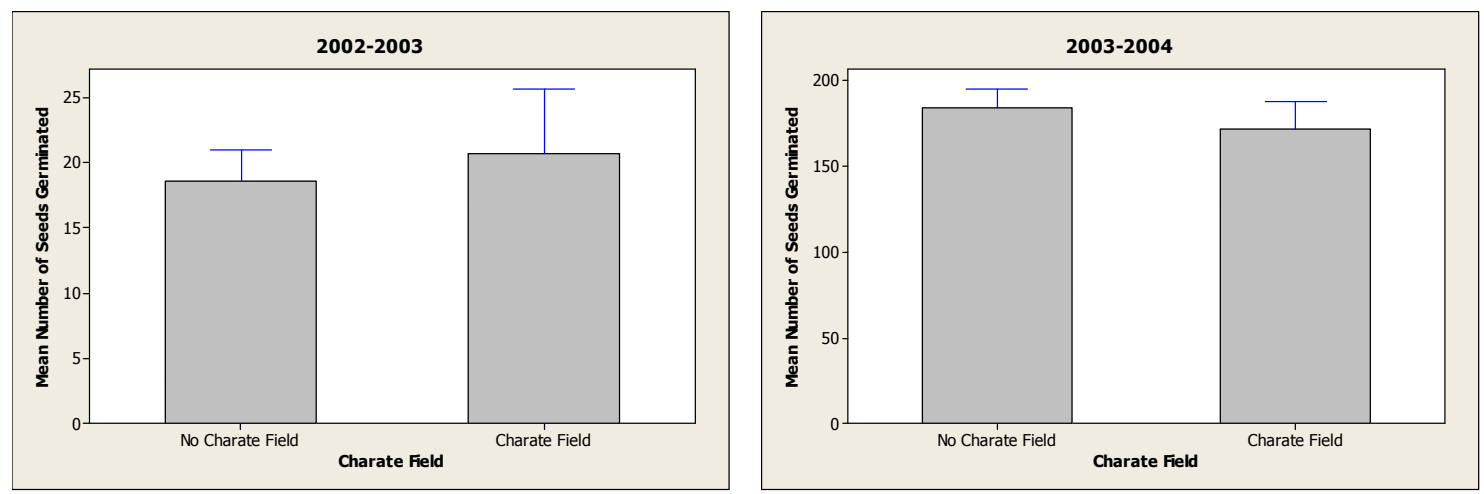

Figures C-2A and 2B. Comparison of Seeds Germinated Without and With Charate Field Using All Data. Error bars represent the standard error of the mean.

\section{Liquid Smoke Soak}
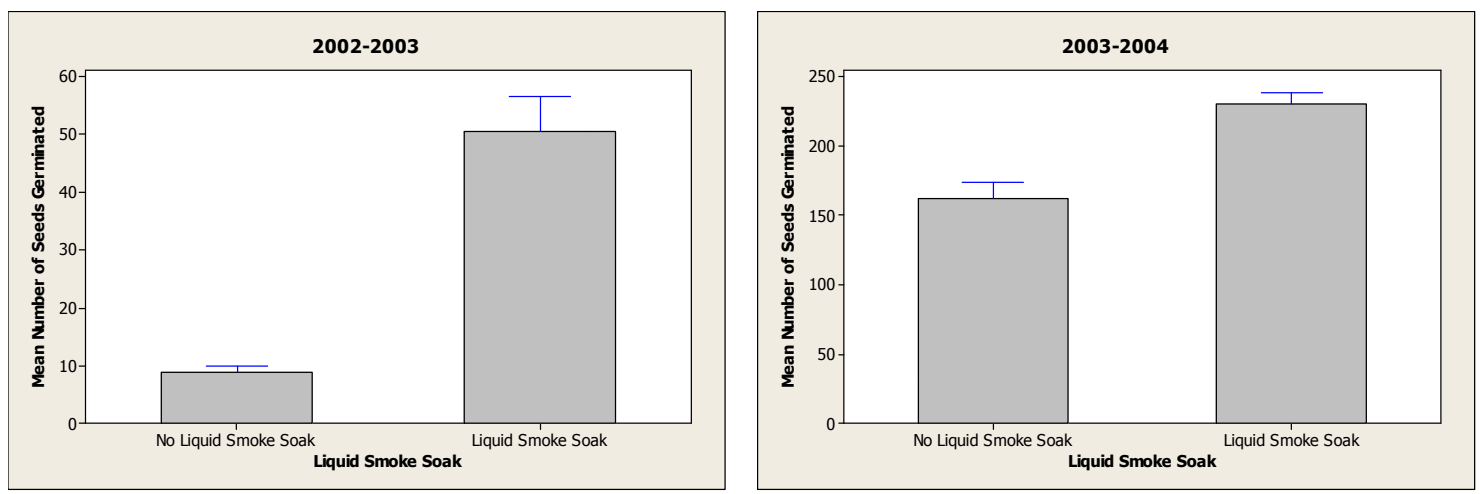

Figures C-3A and 3B. Comparison of Seeds Germinated Without and With Liquid Smoke Soak Using All Data. Error bars represent the standard error of the mean. 


\section{Liquid Smoke Field}
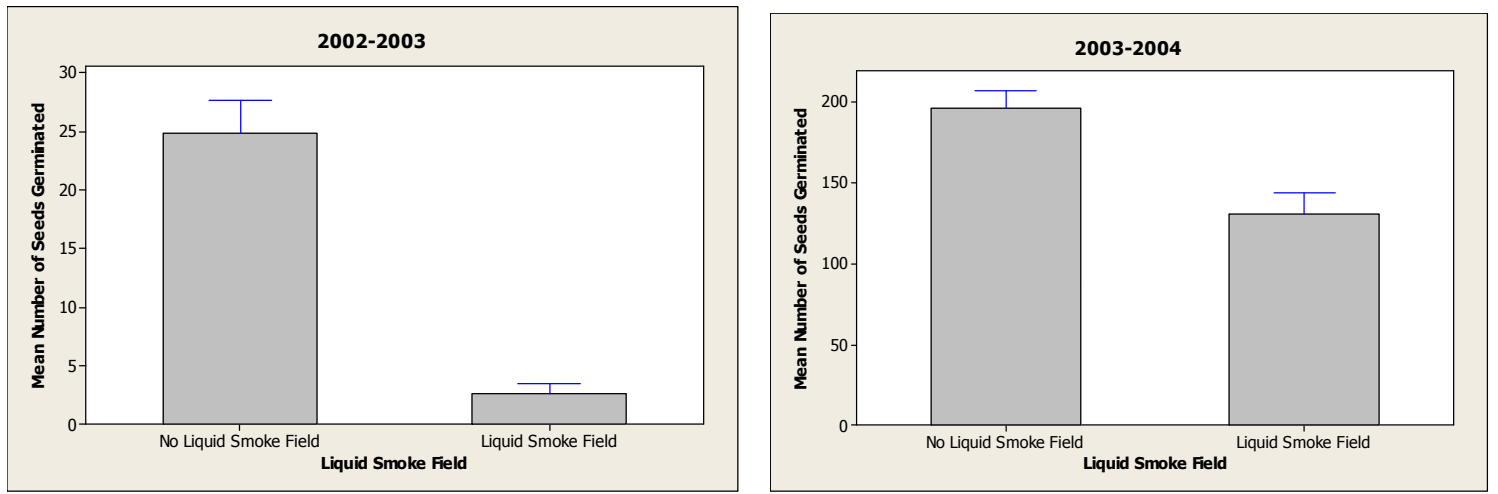

Figures C-4A and 4B. Comparison of Seeds Germinated Without and With Liquid Smoke Field Using All Data. Error bars represent the standard error of the mean.

\section{Chamise Smoke}
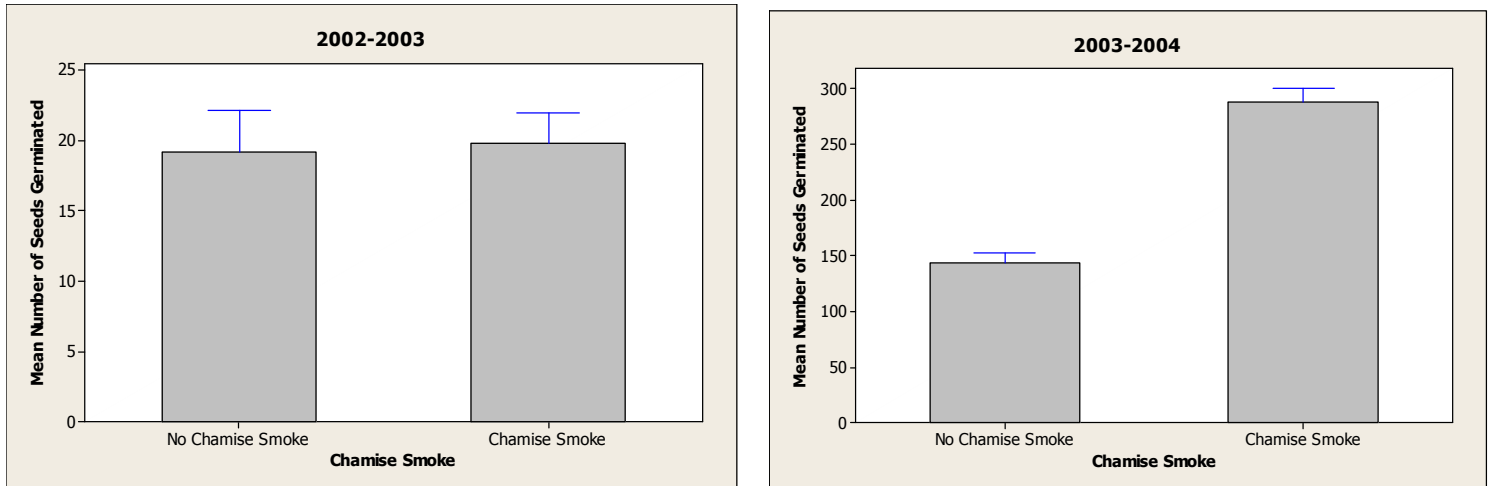

Figures C-5A and 5B. Comparison of Seeds Germinated Without and With Chamise Smoke Using All Data. Error bars represent the standard error of the mean.

\section{Heat and Charate Field}
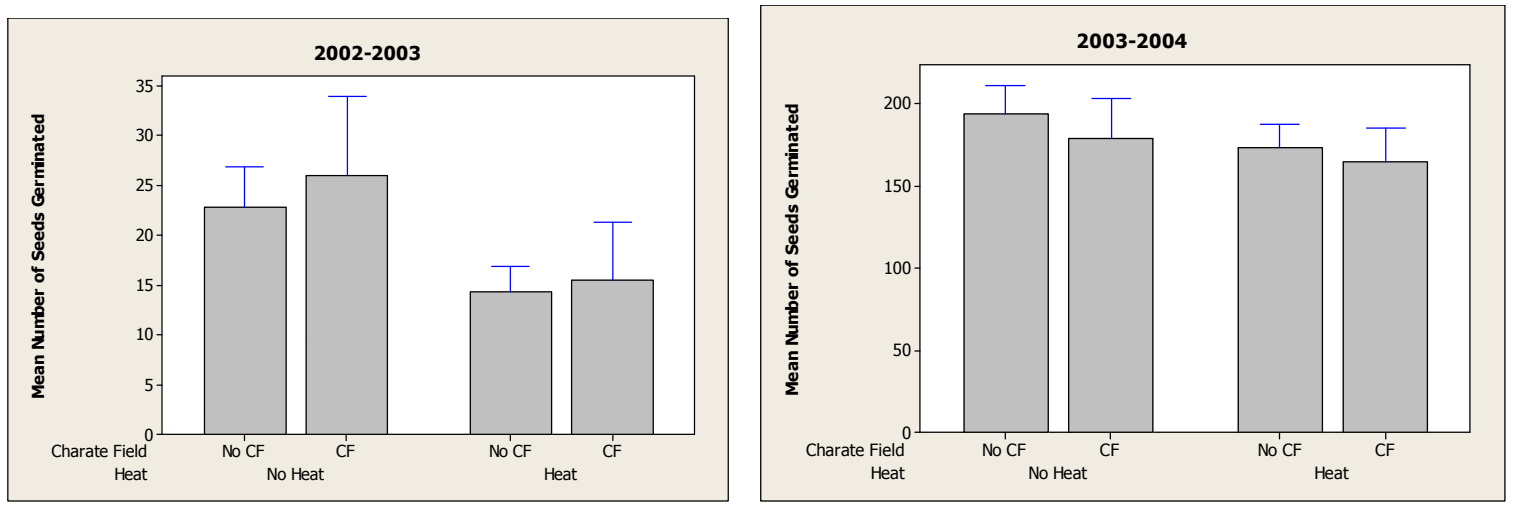

Figures C-6A and 6B. Interaction between Heat and Charate Field Treatments Using All Data. Error bars represent the standard error of the mean. 


\section{Heat and Charate Soak}
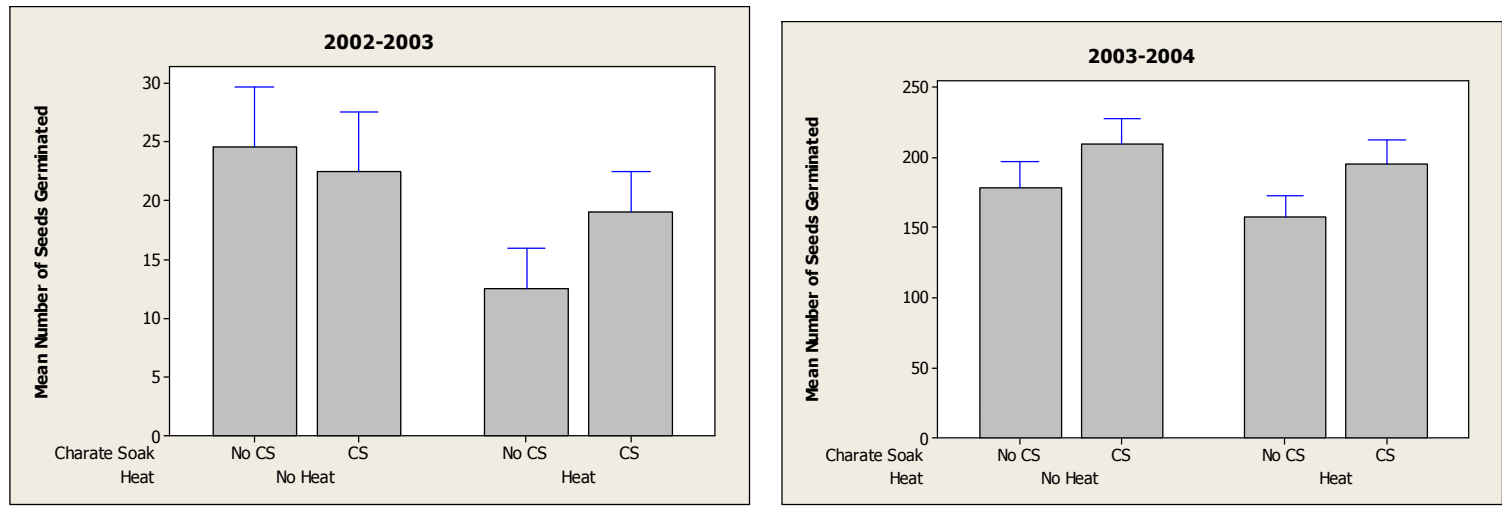

Figures C-7A and 7B. Interaction between Heat and Charate Soak Treatments Using All Data. Error bars represent the standard error of the mean.

\section{Heat and Liquid Smoke Soak}
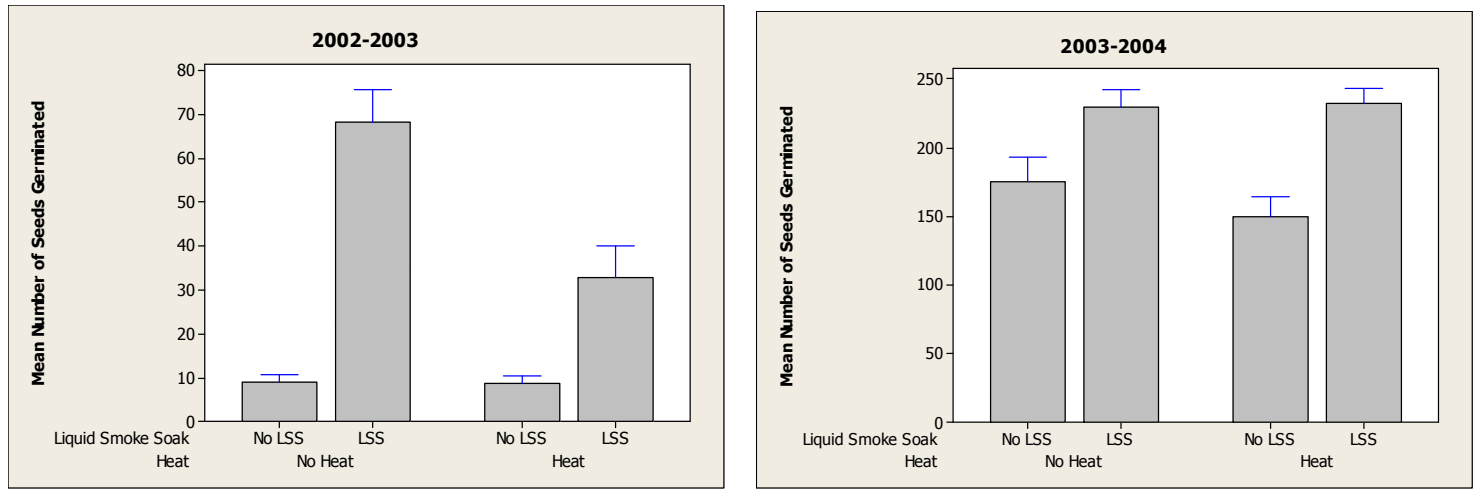

Figures C-8A and 8B. Interaction between Heat and Liquid Smoke Soak Treatments Using All Data. Error bars represent the standard error of the mean.

\section{Heat and Liquid Smoke Field}
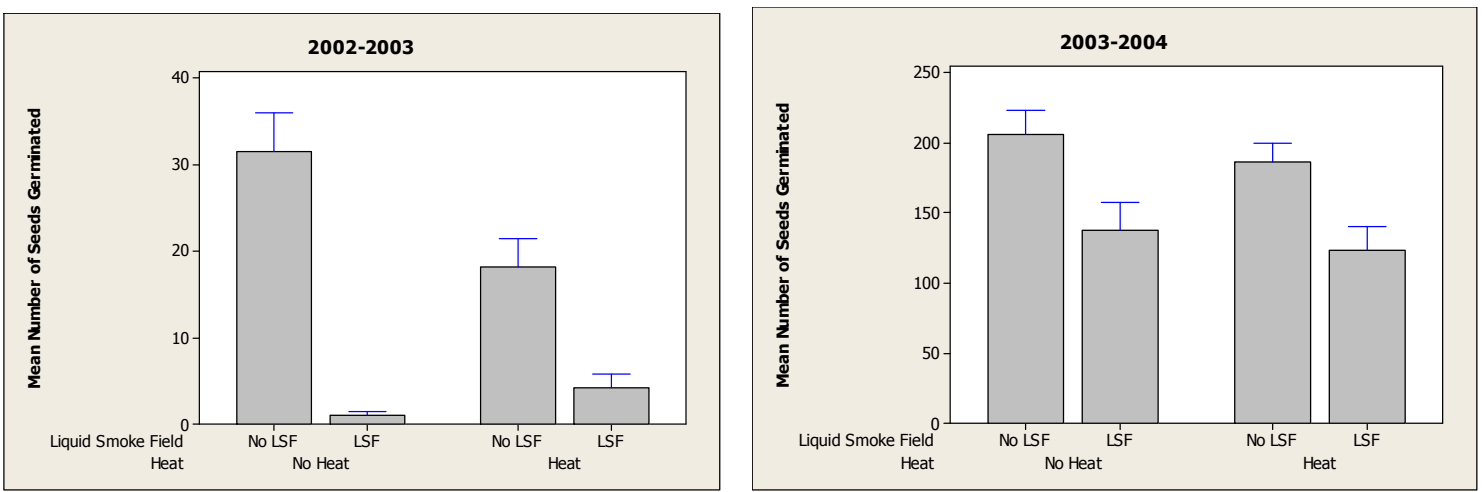

Figures C-9A and 9B. Interaction between Heat and Liquid Smoke Field Treatments Using All Data. Error bars represent the standard error of the mean. 


\section{Heat and Chamise Smoke}
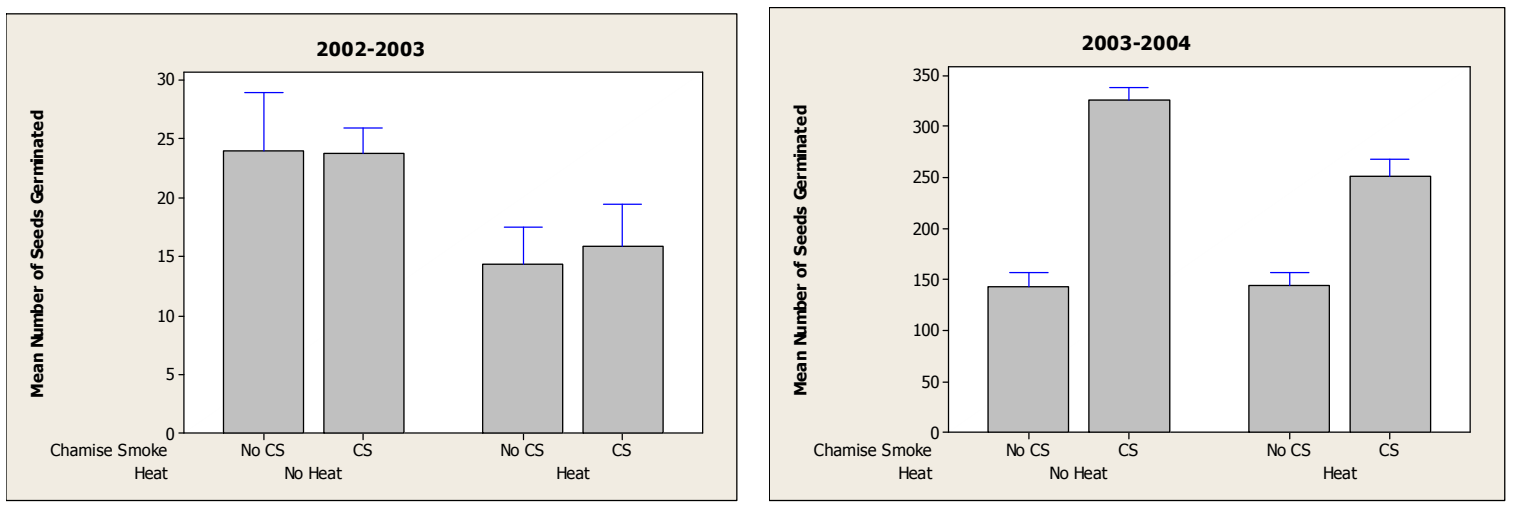

Figures C-10A and 10B. Interaction between Heat and Chamise Smoke Treatments Using All Data. Error bars represent the standard error of the mean.

\section{Charate Soak and Liquid Smoke Soak}
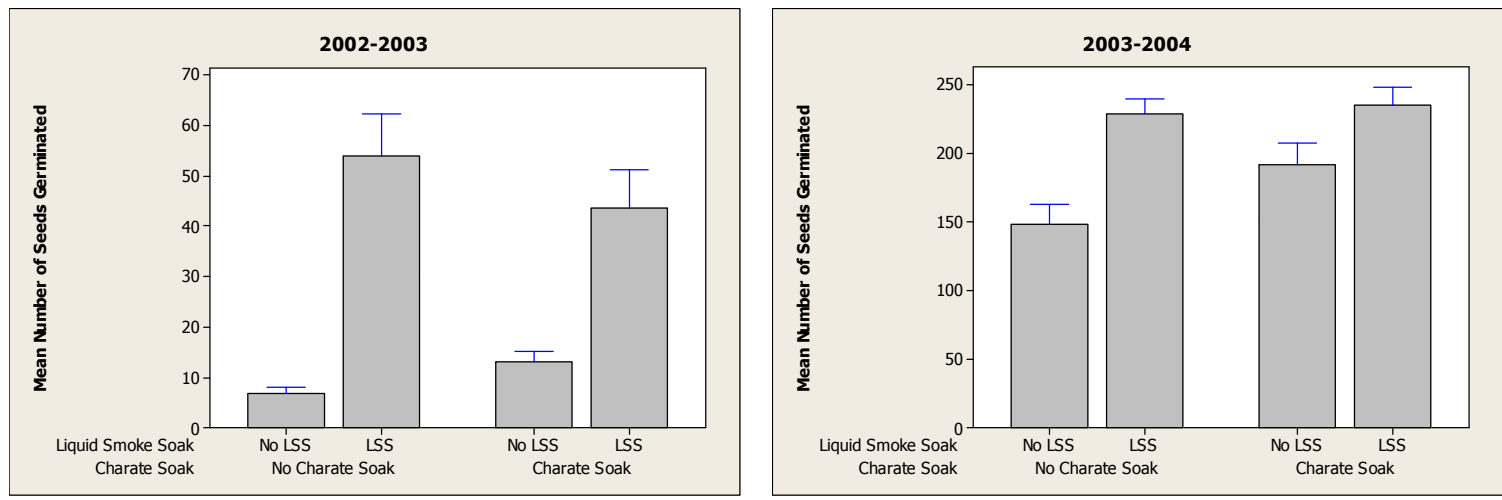

Figures C-11A and 11B. Interaction between Charate Soak and Liquid Smoke Soak Treatments Using All Data. Error bars represent the standard error of the mean.

\section{Charate Soak and Liquid Smoke Field}
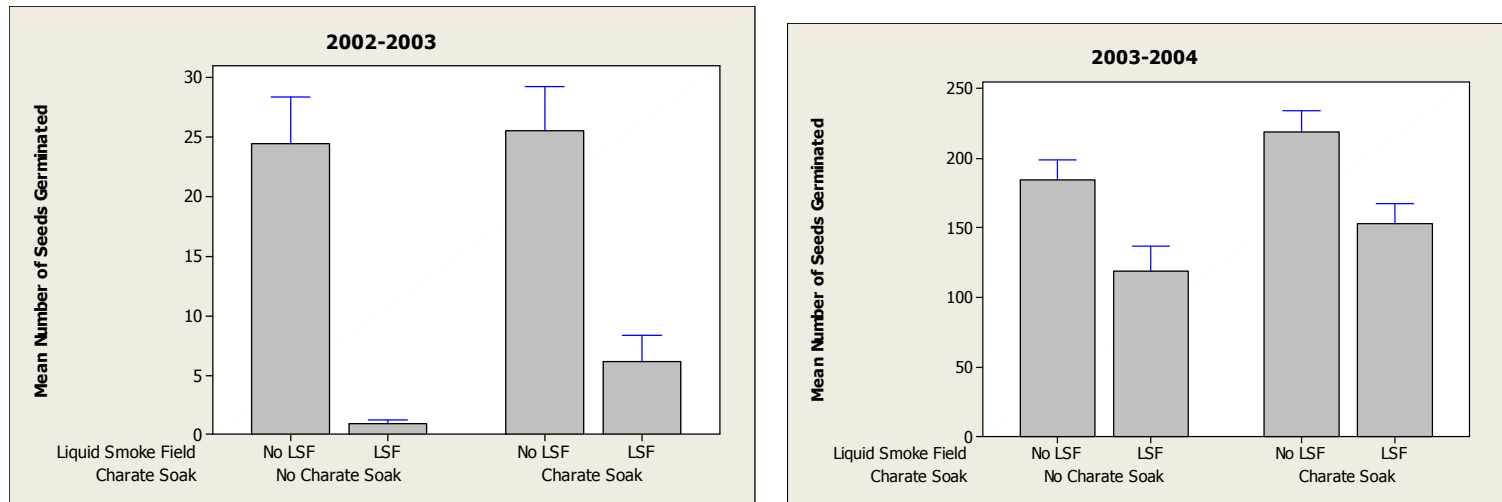

Figures C-12A and 12B. Interaction between Charate Soak and Liquid Smoke Field Treatments Using All Data. Error bars represent the standard error of the mean. 


\section{Charate Soak and Chamise Smoke}
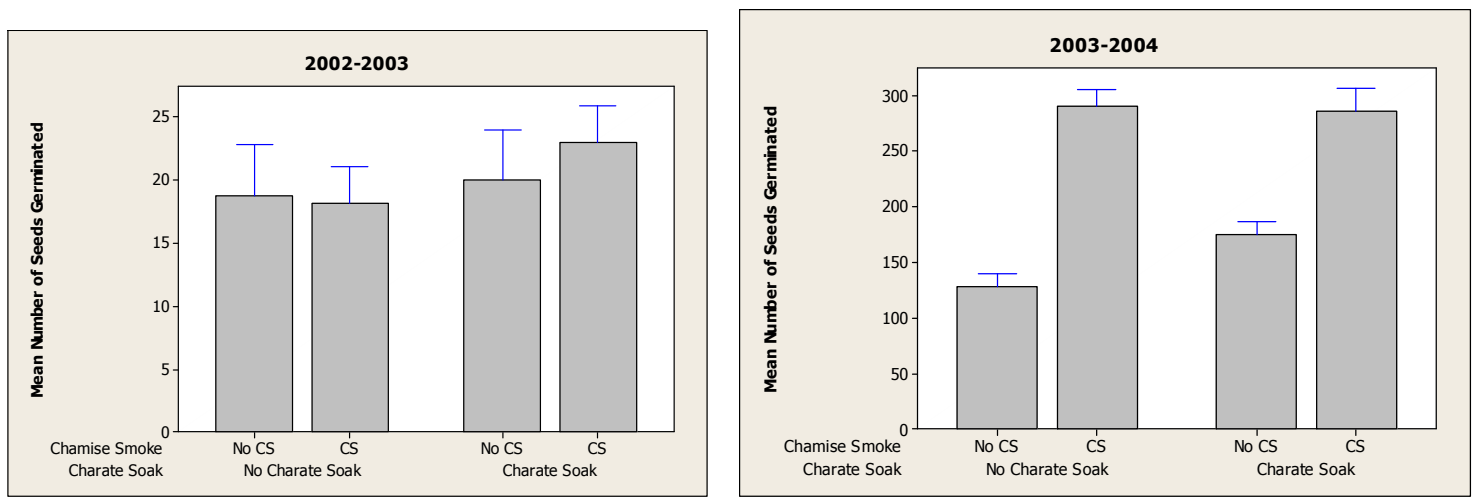

Figures C-13A and 13B. Interaction between Charate Soak and Chamise Smoke Treatments Using All Data. Error bars represent the standard error of the mean.

\section{Charate Soak and Sulfuric Acid Soak}
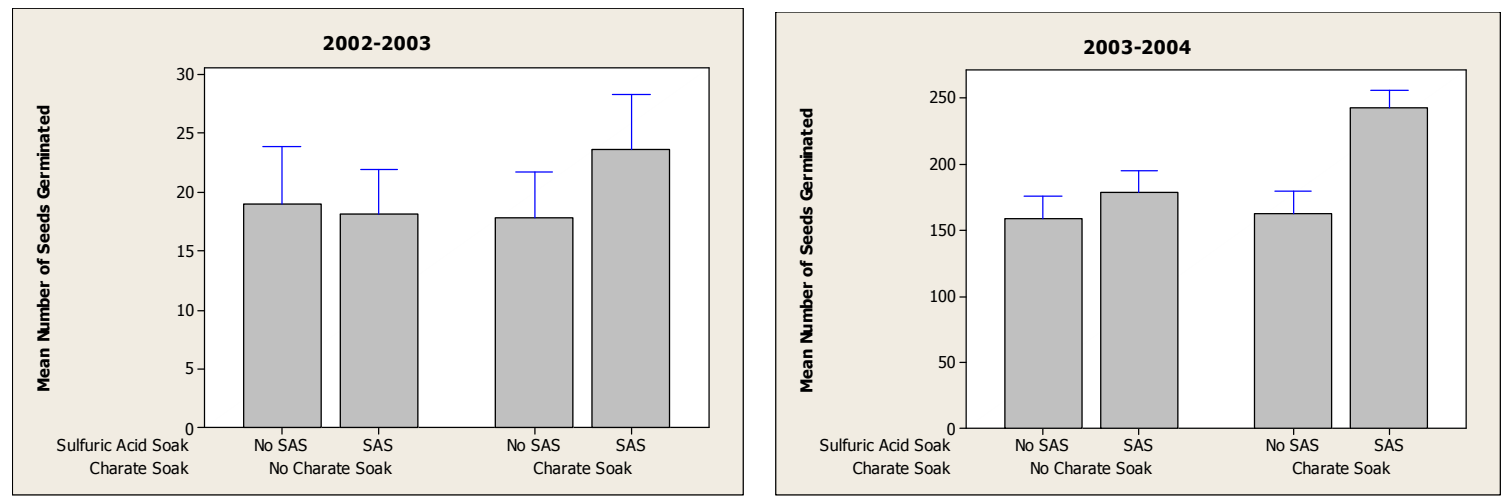

Figures C-14A and 14B. Interaction between Charate Soak and Sulfuric Acid Soak Treatments Using All Data. Error bars represent the standard error of the mean.

\section{Charate Field and Liquid Smoke Soak}
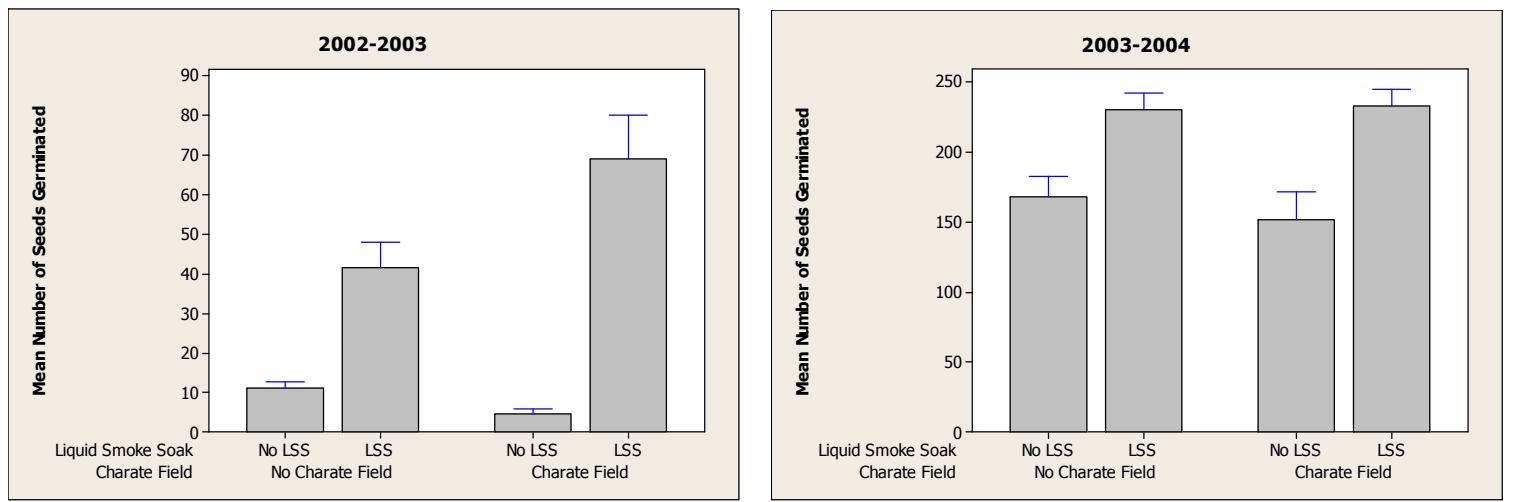

Figures C-15A and 15B. Interaction between Charate Field and Liquid Smoke Soak Treatments Using All Data. Error bars represent the standard error of the mean. 


\section{Charate Field and Liquid Smoke Field}
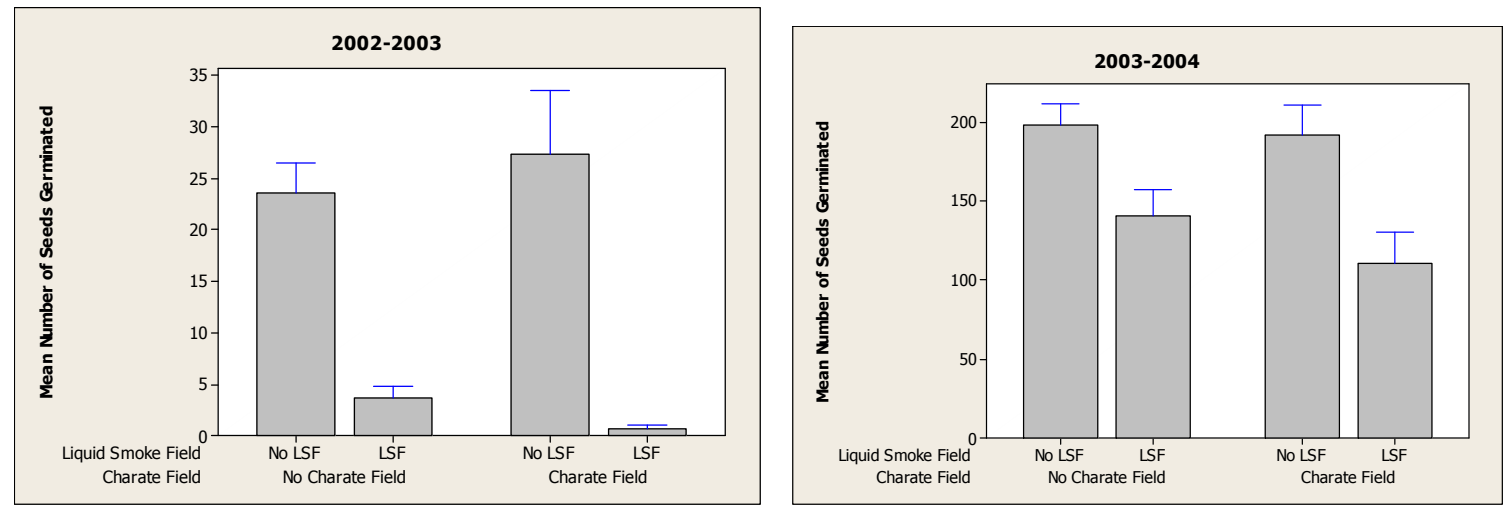

Figures C-16A and 16B. Interaction between Charate Field and Liquid Smoke Field Treatments Using All Data. Error bars represent the standard error of the mean.

\section{Charate Field and Chamise Smoke}
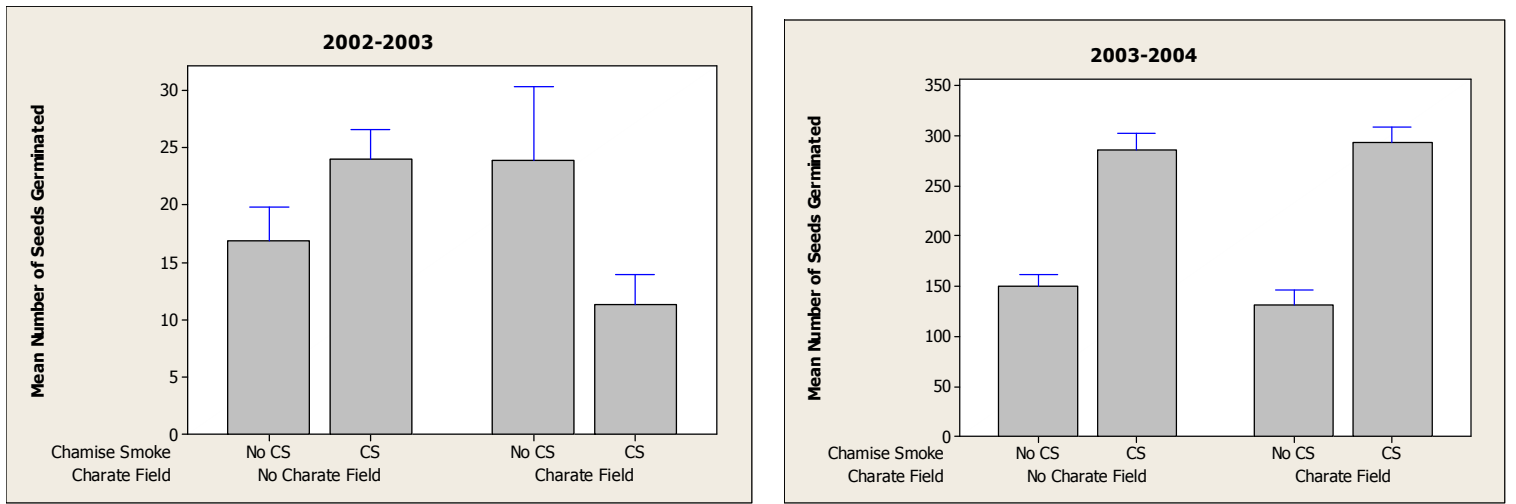

Figures C-17A and 17B. Interaction between Charate Field and Chamise Smoke Treatments Using All Data. Error bars represent the standard error of the mean.

\section{Charate Field and Sulfuric Acid Soak}
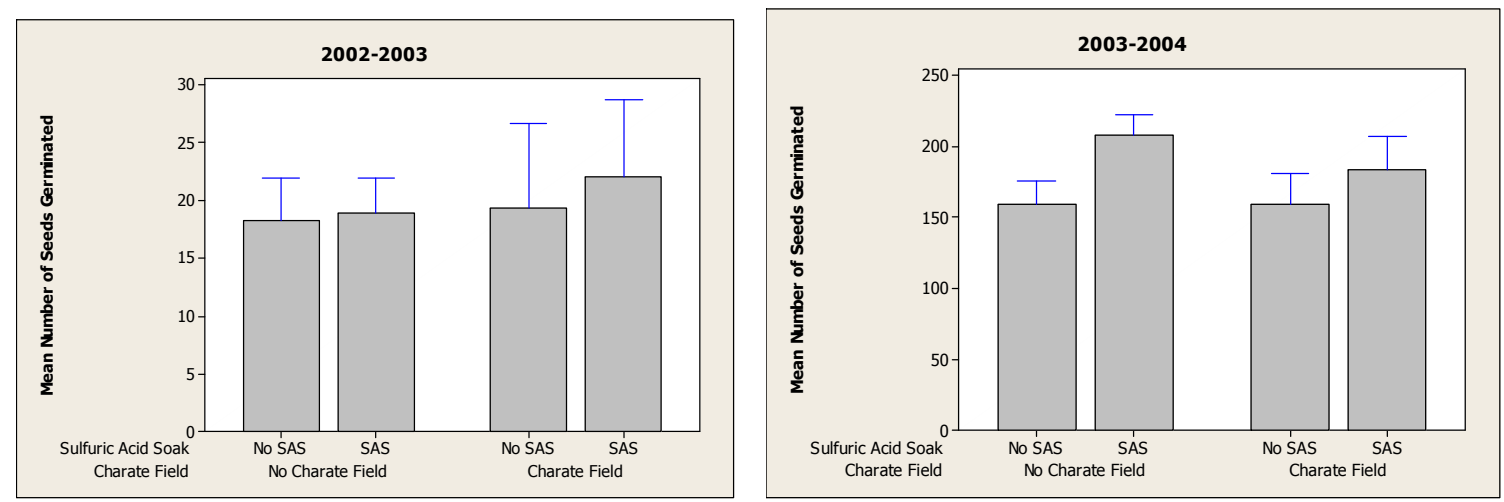

Figures C-18A and 18B. Interaction between Charate Field and Sulfuric Acid Soak Treatments Using All Data. Error bars represent the standard error of the mean. 


\section{Liquid Smoke Soak and Sulfuric Acid Soak}
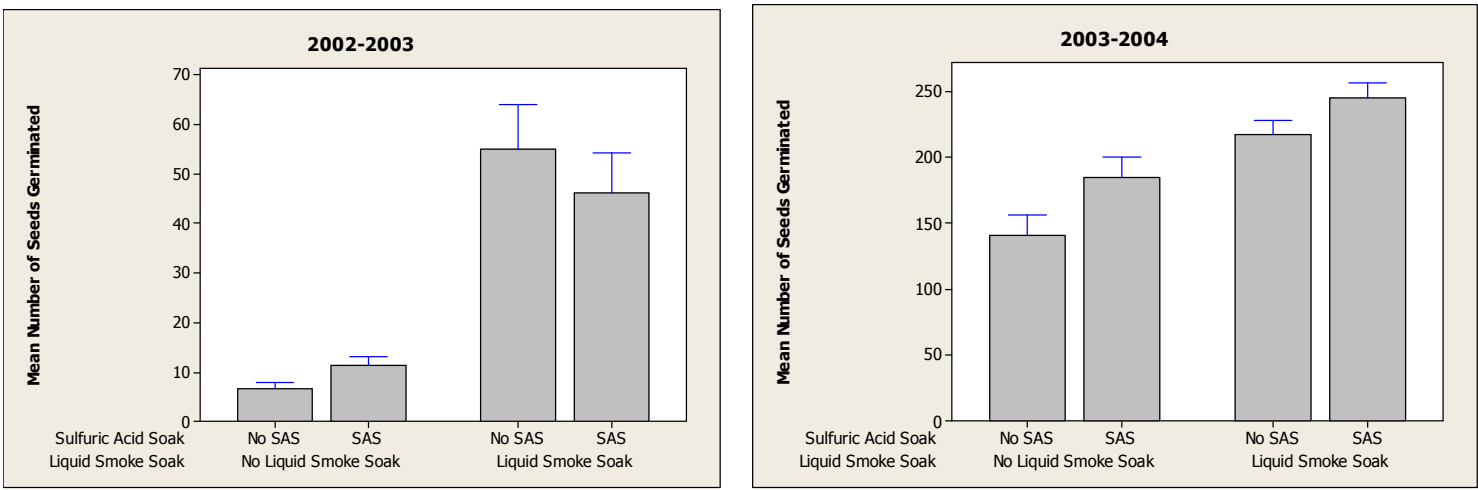

Figures C-19A and 19B. Interaction between Liquid Smoke Soak and Sulfuric Acid Soak Treatments Using All Data. Error bars represent the standard error of the mean.

\section{Liquid Smoke Field and Sulfuric Acid Soak}
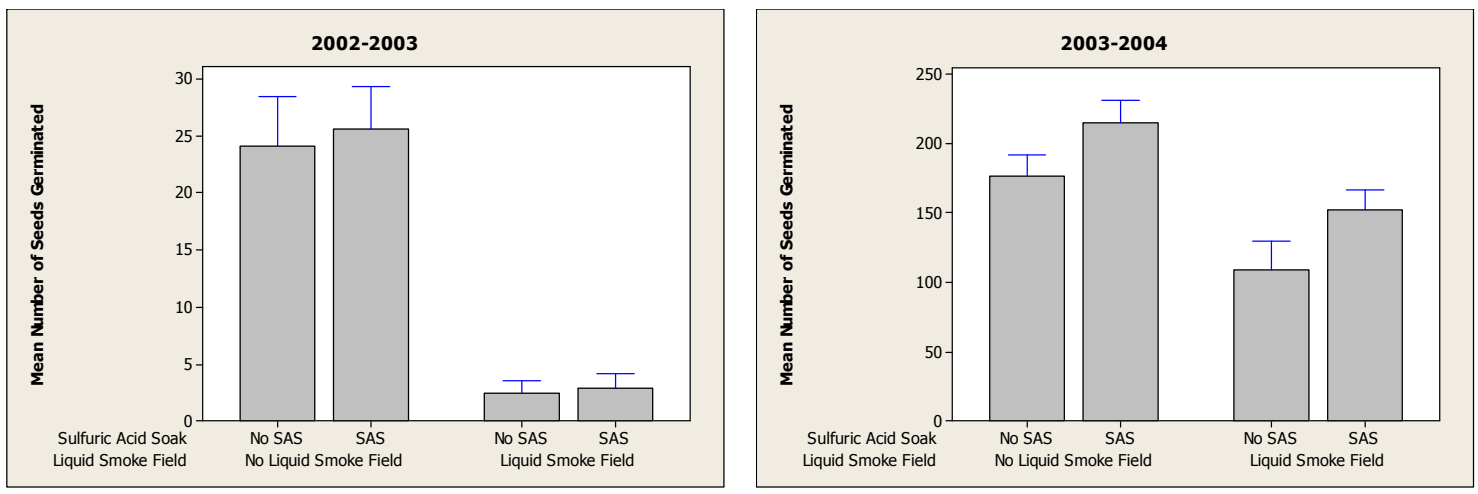

Figures C-20A and 20B. Interaction between Liquid Smoke Field and Sulfuric Acid Soak Treatments Using All Data. Error bars represent the standard error of the mean.

\section{Chamise Smoke and Sulfuric Acid Soak}
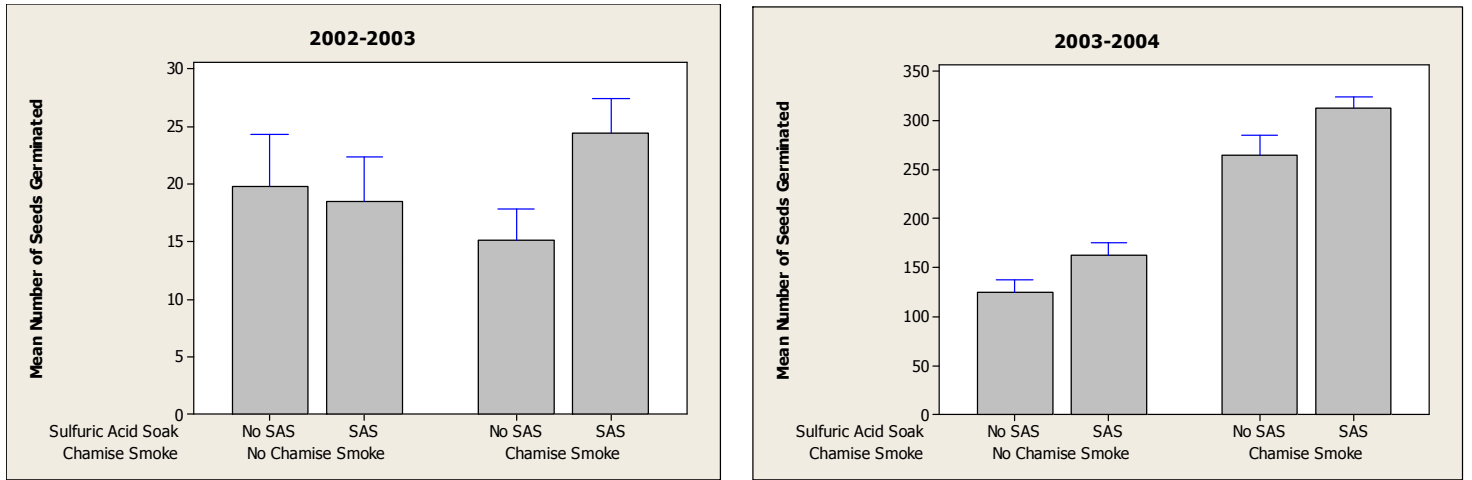

Figures C-21A and 21B. Interaction between Chamise Smoke and Sulfuric Acid Soak Treatments Using All Data. Error bars represent the standard error of the mean. 